ANL/OEPM-80-13

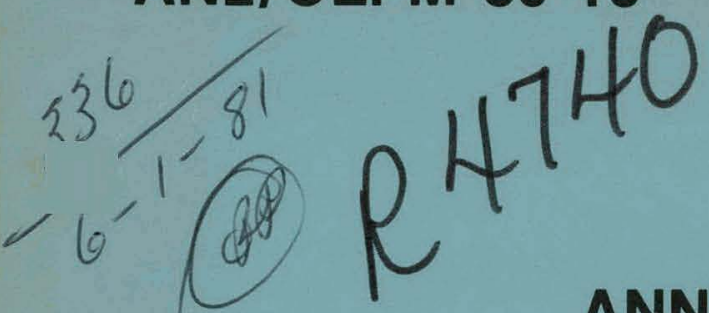

ANL/OEPM-80-13

ANNUAL REPORT FOR 1980 ON

RESEARCH, DEVELOPMENT, AND DEMONSTRATION

OF NICKEL-ZINC BATTERIES FOR

ELECTRIC VEHICLE PROPULSION

Contract No. 31-109-38-4248

by

Energy Research Corporation

ARGONNE NATIONAL LABORATORY, ARGONNE, ILLINOIS

Operated for the U. S. DEPARTMENT OF ENERGY

under Contract W-31-109-Eng-38 


\section{DISCLAIMER}

This report was prepared as an account of work sponsored by an agency of the United States Government. Neither the United States Government nor any agency Thereof, nor any of their employees, makes any warranty, express or implied, or assumes any legal liability or responsibility for the accuracy, completeness, or usefulness of any information, apparatus, product, or process disclosed, or represents that its use would not infringe privately owned rights. Reference herein to any specific commercial product, process, or service by trade name, trademark, manufacturer, or otherwise does not necessarily constitute or imply its endorsement, recommendation, or favoring by the United States Government or any agency thereof. The views and opinions of authors expressed herein do not necessarily state or reflect those of the United States Government or any agency thereof. 


\section{DISCLAIMER}

Portions of this document may be illegible in electronic image products. Images are produced from the best available original document. 
The facilities of Argonne National Laboratory are owned by the United States Government. Under the terms of a contract (W-31-109-Eng-38) among the U. S. Department of Energy, Argonne Universities Association and The University of Chicago, the University employs the staff and operates the Laboratory in accordance with policies and programs formulated, approved and reviewed by the Association.

\section{MEMBERS OF ARGONNE UNIVERSITIES ASSOCIATION}

The University of Arizona

Carnegie-Mellon University

Case Western Reserve University

The University of Chicago

University of Cincinnati

Illinois Institute of Technology

University of Illinois

Indiana University

The University of Iowa

Iowa State University
The University of Kansas

Kansas State University

Loyola University of Chicago

Marquette University

The University of Michigan

Michigan State University

University of Minnesota

University of Missouri

Northwestern University

University of Notre Dame
The Ohio State University

Ohio University

The Pennsylvania State University

Purdue University

Saint Louis University

Southern Illinois University

The University of Texas at Austin

Washington University

Wayne State University

The University of Wisconsin-Madison

NOTICE

This report was prepared as an account of work sponsored by an agency of the United States Government. Neither the United States Government or any agency thereof, nor any of their employees, make any warranty, express or implied, or assume any legal liability or responsibility for the accuracy, completeness, or usefulness of any information, apparatus, product, or process disclosed, or represent that its use would not infringe privately owned rights. Reference herein to any specific commercial product, process, or service by trade name, mark, manufacturer, or otherwise, does not necessarily constitute or imply its endorsement, recommendation, or favoring by the United States Government or any agency thereof. The views and opinions of authors expressed herein do not necessarily state or reflect those of the United States Government or any agency thereof.

Printed in the United States of America

Available from

National Technical Information Service

U. S. Department of Commerce

5285 Port Royal Road

Springfield, VA 22161

NTIS price codes

Printed copy: A12

Microfiche copy: A01 
Distribution Category:

Energy Storage-Electrochemical--

Near-Term Batteries (UC-94ca)

ANL/OEPM $-80-13$

\author{
Annual Report for 1980 on \\ RESEARCH, DEVELOPMENT, AND DEMONSTRATION \\ OF NICKEL-ZINC BATTERIES FOR \\ ELECTRIC VEHICLE PROPULSION
}

Prepared for

The Office for Electrochemical Project Management

Argonne National Laboratory

Under Contract No. 31-109-38-4248

by

Energy Research Corporation

Danbury, Connecticut

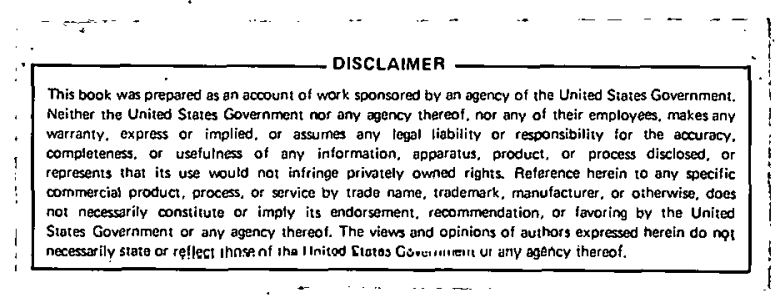

March 1981 


\title{
ENERGY RESEARCH CORPORATION
}

THIRD ANNUAL NON-PROPRIETARY REPORT 1980

CONTRACT NO. 31-109-38-4248

Prepared For:

ARGONNE NATIONAL LABORATORY

9700 South Cass Avenue

Argonne, Illinois $60439^{\circ}$

Attention: Dr. N.P. Yao

\author{
Submitted By: \\ Energy Research Corporation \\ Stanley Januszkiewicz \\ Hari Vaidyanathan \\ Mark Dodin \\ Tony Leo
}

Approved By:

Allen Charkey

Program Manager

\author{
Date: \\ January 30,1981
}


TABLE OF CONTENTS

Page No.

SECTION I

EXECUTIVE SUMMARY --

SECTION II

NICKEL ELECTRODE DEVELOPMENT FOR NICKEL-ZINC CELLS-(TASK I)---- 5

1. 0 INTRODUCTION $---1-0$

2.0 TECHNICAL DISCUSSION ---1

2.1 ERC $1.5 \%$ COBALT-NICKEL HYDRATE

2.2 GRAPHITE ADDITION DURING HYDRATE PREPARATION -

2.3 STANDARD VS CELLOPHANE WRAP

2.4 SODIUM HYDROXIDE ADDITION

2.5 COMMERCIAL NI HYDPATE I: EFFECT OF PARTICLE SIZE ------ 20

2.6 COMMERCIAL NI HYDRATE I: PREFORMED PLATES -

2.7 COMMERCIAL NI HYDRATE I (MAY 1980)

2.8 COMMERCIAL NICKEL HYDRATES II -

2.9 COIMERCIAL NICKEL HYDRATES III

2.10 COMMERCIAL NICKEL HYDRATE IV

2.11 INICKEL-ZINC VS NICKEL-CADMIUM PERFORMANCE -------------- 28

2.12 TEFLONIZED GRAPHITE

2.13 ERC NICKEL HYDRATE VARIATIONS - 32

2.14 ELECTROLYTE ADDITIVES - 34

3.0 CONCLUSIONS

4. 0 FUTURE WORK -19 
TABIE OF CORTENTS

Page No.

SECTION III

ZINC ELECTRODE DEVELOPMENT FOR NI-ZN CELIS - (TASK II)-------- 40

1.0 INTRODUCTION -

2.0 TECHNICAL DISCUSSION

2.1 BASIC ELECTROCHEMICAL STUDY -

2.1.1 Experimental -

2.1.2 Dependence of Kinetics on $\mathrm{OH}^{-}$Concentration --------- 43

2.1.3 Electrode Polarization, Tafel Slope and Exchange Current- 53

2.1.4 Physical Significance of the Polarization Results ------ 56

3. 0 CONCLUSIONS $-\cdots$

SECTION IV

SEPARATOR DEVELOPMENT FOR NICKEL-ZINC CELLS - (TASK III) ------ 73

1.0 INTRODUCTION -

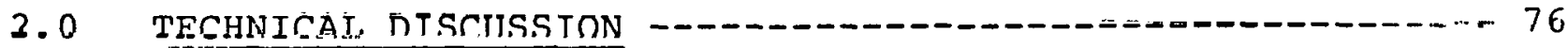

2.1 IMPROVED COMPOSITION AND PRODUL'I'LUN TECHNOLOGY FOR CROGSLINKED PVA SEPARATOR FILMS -

2.1.1 Various Compositions for Improved Crosslinked PVA Separator - -

2.1.2 Zinc Penetration Test

2.1.3 The Permeability Mechanism Through PVA Films --------- 91

2.1.4 Failure Mode observatiun of Cells containing PVA Based Separator Films -

2.2 IMPROVED COMPOSITION FOR POLYMER-BLEND SEPARATOR FILMS -- 101

2.2.1 Evaluation of Polymer-Blend as a Separator Material ---- 102

2.2.2 Testing of Cells Containing one Layer of Polymer-Blend Separator Films - -

2.3 DESIGN AND TEST RESULTS OF THE. IMPROVED SEPARATOR SYSTEM- 119 
TABLE OF CONTENTS

Page No.

2.3.1 Small Cell Testing of Various Separator Systems ------ 119

2.3.2 Testing Different Separator Systems in Full Size, Single Electrode Cells - 138

3.0 CONCLUSIONS - 152

3.1 PVA-BASED SEPARATOR MATEIALS - 152

3.2 POLYMER-BLEND SEPARATOR MATERIALS - 155

3.3 DESIGN AND TEST RESULTS OF THE IMPROVED SEPARATOR SYSTEM- 155

4.0 FUTURE WORK

SECTION $\mathrm{V}$

DEVELOPMENT OF SEALED NICKEL-ZINC CELLS - (TASK IV) -

1.0 INTRODUCTION-D-159

2.0 TECHNICAL DISCUSSION-- 160

2.1. EXPERIMENTAL :SEPARATOR AND ABSORBER DESIGNS -

2.2 CELLS WITH Ag-HgO RECOMBINATION ELECTRODE PARTITIONS ---- 166

3.0 CONCLUSIONS AND FUTURE WORK SECTION VI

SYSTEM ENGINEERING (TASK V)

1.0 INTRODUCTION - 184

2.0 TECHNICAL DISCUSSION - 185

2.1 TESTING OF 20 AMPERE-HOUR CELLS

2.1 .1 zinc Electrode Tests

2.1 .2 Investigation of Alternate Electrolytes - 188

2.2 FULL-SIZE, SINGLE ELECTRODE TESTS - 190

2.2.1 Evaluation of Zinc Electrode Designs - 


\section{TABLE OF CONTENTS}

Page No.

2.2.2 Evaluation of Separator System Design $-\cdots$

2.3250 AH CELL TESTS

2.3.1 Cell Test with PVA Separator and $\mathrm{Bi}_{2} \mathrm{O}_{3}$ Zinc Electrode Additive -

2.3.2 Cell Tests with Advanced Separator and Electrode Designs- 206

2.3.3 Simulated Vehicle Use Test

3.0 CONCLUSIONS - 220

4.0 FUTURE WORK 


\section{LIST OF FIGURES}

Figure No.

Page No.

SECTION II

NICKEL ELECTRODE DEVELOPMENT FOR NICKEL-ZINC CELLS - (TASK I)

I.1 Effect of Cycling 250 Ah Single Plate $\mathrm{Ni-2n}$ Cell ----- 29

SECTION III

ZINC ELECTRODE DEVELOPMENT FOR NI-ZN CELLS - (TASK II)

II.1 Electrochemical Cell for Cycling and Polarization

Experiments - -

II.2 The Dependence of $\mathrm{Z}$ inc Potential on $\mathrm{OH}^{-}$Concentration at Open Circuit -

II.3 Dependence of Reaction Rate on pH at a Constant Overvoltage of $15 \mathrm{mV}$ from $E_{\text {OCV }}$ Before Cycling

II. 4 Dependence of Reaction Rate on $\mathrm{pH}$ at a Constant

Overvoltage of $15 \mathrm{mV}$ from $\mathrm{E}_{\mathrm{OCV}}$ After Cycling

II.5 Dependence of Reaction Rate on $\mathrm{pH}$ at a Constant Overvoltage of $20 \mathrm{mV}$ from $E_{\text {OCV }}$ Before Cycling

II. 6 Dependence of Reaction Rate on $\mathrm{pH}$ at a Constant Overvoltage of $20 \mathrm{mV}$ from $\mathrm{E}_{\text {OCV }}$ After Cycling -

SECTION IV

SEPARATOR DEVELOPMEINT FOR NICKEL-ZINC CELLS - (TASK III)

III.l Zinc Penetration mest Cell

III.2 Effect of Exposure Time in KOH on the Electrical Resistance of PVA Films -

III. 3 Electrical Resistance vs $\mathrm{OH}^{-}$Diffusion for (2N) Polymer-Blend -n--

III.4 Pore Size Distribution of Polymer-Blend Film --------- 111

III.5 Dependence of Cell Capacity and End-Of-Discharge Voltage on Number of Cycles -

III. 6 Dependence of Cell Capacity and End-of-Discharge Voltage on Number of Cycles, Cells 6 and 8 


\section{LIST OF FIGURES}

Figure No.

Page No.

III. 7 Dependence of Cell Capacity and End-Of-Discharge Voltage on Number of Cycles, Cells 9 and $10 \ldots$

III.8 Dependence of Cell Capacity and End-Of-Discharge Voltage on Number of Cycles, Cell 9

III.9 Dependence of Cell Capacity on Number of Cycles ------ 142

III.10 Dependence of lell capac1ty on Number Uf Cycles -a=---- 143

III.11 Dependence of Cell Capacity on Number of Cycles ------ 150

III.12 Dependence of Cell Capacity on Number of Cycles ------ 151

III.13 Dependence of Cell Capacity on Number of Cycles ------ 153

III.14 Dependence of Cell Capacity on Number of Cycles ------ 154

SECTION V

DEVELOPMENT OF SEALED NICKEL-ZINC CELLS - (TASK IV)

IV.1 Pressure and Voltage on a. $4 \mathrm{~A}$ Charge for Cells S-I-1, S-1-2 and S-2 -

IV. 2 Ni-"zn Cell with Recombination Electrode Partition ----- 167

IV. 3 Pressure and Recombination Current on $4 \mathrm{~A}$ Charge

for Cell 2R- 168

IV. 4 Charge Efficiency on Charge for Cell 2R-5 (Based on

$\mathrm{O}_{2}$ Recombination Current) 169

IV. 5 Open Circuit oxygen Recombination for Cell 2R-5 ------ 171

IV. 6 Relationship Between Recombination Rate and :Oxygen

Pressure During Open Circuit Recombination, Cell 2R-5 - $1 \% 2$

IV.7 Performance of Cell 2R7 on Cycle \#7 173

IV. 8 Performance of Cell $2 \mathrm{R} 8$ on Cycle \#7 179

IV.9 Cell 2R7 Recombination Rate vs $\mathrm{O}_{2}$ Pressure 


\section{LIST OF FIGURES}

Figure No.

Page No.

SECTION VI

SYSTEM ENGINEERING - (TÁSK V)

$\mathrm{V} .1$ Cycle Performance of Cells with $\mathrm{Bi}_{2} \mathrm{O}_{3}$ Additive --- - - 187

V.2 Cycling Heat-Treated zno - 2 (89

V.3 Standard Ni-Zn Design in Different Test Cell

Constructions all on Constant Current Cycle

V.4 Cycle Data for Cell SE-12

V.5 Cycle Data for Cells with Pbo/Cdo Additive ---------- 199

V. 6 Cycle Test Results of Cells with PVA Separator and $\mathrm{Bi}_{2} \mathrm{O}_{3} \mathrm{Zinc}$ Additive -

V.7 Ni-zn Cycle Test with Various Charge Procedures PVA Separator and $\mathrm{Bi}_{2} \mathrm{O}_{3}$ Additive

V.8 Cycle Performance of Cells with Pellon and Asbestos Absorber -

V.9 250 Ah Cycle Data

V.10 250 Ah Cell Cycle Test Data

V.11 Cell 151-1 Voltage and Temperature Data for Cycle 59 -- 213

V.12 Cell 157 Long Cell Voltage and Temperature Data for Cycle.55

V.13 Four Current steps to Provide a Simplified Approximation to the J227AD/DOE-GE-Chrysler Vehicle (with regenerative braking)

V.14 Weekly Variable Depth Test Sequence -

V.15 Simulated EV Use Testing of Cell 162

V.16 Variable Depth Life Test 


\section{LIST OF TABLES}

Table No.

Page No.

SECTION II

NICKEL ELECTRODE DEVELOPMENT FOR NICKEL-ZINC CELLS - (TASK I)

I. 1 1.5\% Cobalt-Nickel Hydrate 20 Ah Ni-Cd Cells -------- 9

I. 2 1.5\% Cobalt-Nickel Hydrate Treated Graphites, 20 Ah

Ni-Cd Cells -

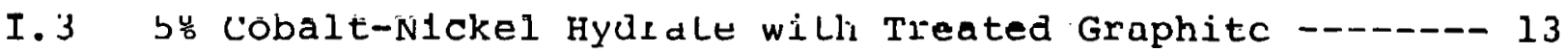

I.4 Effect of Added Graphite on 5\% Cobalt=ivickel Hyuiate -- 15

I. 5 Standard vs Cellophane Wrap, ERC 10\% CO-Ni(OH) 2 ;

$20 \mathrm{Ah} \mathrm{Ni-Cd} \mathrm{Cells}$

I. 6 5\% Sodium Hydroxide, 5\% Cobalt-Nickel Hydrate, 20 Ah

$\mathrm{Ni}-\mathrm{Cd}$ Cells $-\cdots-\cdots$

I. 7 Commercial Hydrate I coarse and Fine Hydrate, 20 Ah $\mathrm{Ni-Cd}$ Cells -

I. 8 Commercial $\mathrm{Ni}$ Hydrate I Preformed Plates, 20 Ah Ni-Cd

Cells - -

I.9 Commercial Ni Hydrate I, May 1980, 20 Ah Ni-Cd Cells - 23

I.10 Commercial Nickel Hydrates II, $1008 \mathrm{Ni}(\mathrm{OH})_{2} ; 20 \mathrm{Ah}$ Ni-Cd Cells - 25

I.II Other Nickel Hydrates, 20 Ah Ni-Cd Cells

I.12 Nickel-Zinc vs Nickel-Cadmium, ERC $1.5 \%$ Cobalt-Nickel, 250 Ah Single plate cell 30

I.13 ERC 1.5\% Cobalt-Nickel Variations, 250 Ah Single Plate $\mathrm{Ni-Zn}$ Cells $---\cdots$

I.14 Electrolyte Additives, Commercial Ni Hydrate I, $250 \mathrm{Ah}$ Single.Plate $\mathrm{Ni}-\mathrm{Zn}$ Cells

SECTION III

ZINC ELECTRODE DEVELOPMENT FOR NI-ZN CELLS - (TASK II)

A. 1 Electrode P-IIB 60

A. 2 Electrode P-IIC

Page No. viii 


\section{LIST OF TABLES}

Table No.

Page No.

A. 3 Electrode P-IID

A. 4 Electrode P-IIE

A. 5 Electrode P-IIIA

A. 6 Electrode P-IVA

A. 7 Electrode P-VA

A.8 Comparison of Polarization Data Before Cycling ------ 67

A. 9 Comparison of Polarization Data After Initial Cycling- 68

A.10 Comparison of Polarization Data After 32 Cycles ----- 69

A.11 Comparison of Polarization Data After 43 Cycles ------ 70

A.12 Comparison of Polarization Data After 57 Cycles ----- 71

A.13 Comparison of Polarization Data After 69 Cycles ------ 72

SECTION IV

SEPARATOR DEVELOPMENT FOR NICKEL-ZINC CELLS - (TASK III)

III.l Characteristics of Various PVA Films

III.2 Testing of Various PVA Films - 79

III. 3 Tensile strength and Deflection of Various PVÄ Films - 80

III. 4 Test Results for Small Cells

III.5 Electrical Resistance of PVA-Based Films -

III.6 Tensile Hanging Test for PVA-Based Films

III.7 F.lectrical Resistance of PVA Films Crosslinked with Glutaraldehyde and P-Phenylenediamine - 87

III. 8 Tensile Hanging Test for PVA Films Crosslinked with Glutaraldehyde and P-Phenylenediamine

III.9 Time of zinc Penetration for PVA-Based Separator Films -

III.10 Concentration of Residual Solvent and Electrical Resistance of PVA Films

Page No. ix 


\section{LIST OF TABLES}

Table No.

Page No.

III.ll Variation in Electrical Resistance of PVA Films Containing Different Quantities of Residual Solvent - - 35

III.12 Constants of Equation (3) for PVA-Based Systems -

III. 13 Electrical Resistance of Iylon-Based Films During Extended Exposure Time in $\mathrm{KOH}$

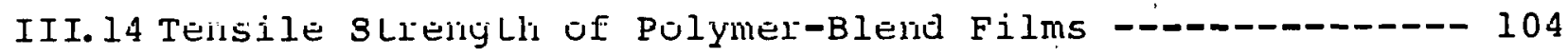

III.15 Comparison of $\mathrm{Zinc}$ Penetration Time for Polymer-Blend Separator Films - 105

III.16 Electrolyte Diffusion Rate Measurements - 107

III. 17 Results of Testing Different Polymer-Blend Films ----- 108

III.18 Cumulative Pore Size Distribution of Polymer-Blend

Film -

III.19 Quantity of Residual Solvent in Polymer-Blend Films --- 113

III.20 Influence of Separator Design on the Zinc Electrode and on Cycle Life of the cell

III. 21 Comparison of $\mathrm{K}-307$ and Polymer-Blend Separators ------ 117

III.22 Time of 2 inc Penetration for Improved Separator System- 121

III.23 Effect of Separator Configuration on Cycle Life and

Failure Mode -

III. 24 Test Results for Cells with Various Separator systems - 124\&125

III.25 zn Penetration Time for ERC-Developed and Commercially

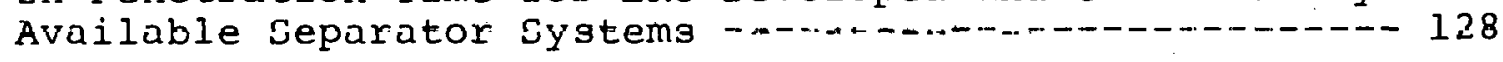

III. 26 Effect of Other Separator Configurations on Cycle Life and Failure Mode of the Cells

III.27 Cycle Life of the Cells Containing Immobilizers for Liquid Layer in Separator System 137

III.28 Cycle Life of Full size Single Electrode Cells ------- 140

III.29 Cycle Life of the Full Size Cells Containing Liquid Layer in the separator system $144 d$ 


\title{
LIST OF TABLES
}

Table No.

Page No.

III.30 Test Results of the Full size cells containing

Different Separator Systems - 147

\begin{abstract}
SECTION $V$
DEVELOPMENT OF SEALED NICKEL-ZINC CELLS - (TASK IV)

IV.I Cycle Test Results of Cells with Coated Celgard

Film -

IV. 2 Performance Data for sealed Cells

IV. 3 Formation Data for Cells with Recombination Electrodes- 175

IV. 4 Cycle Performance of Sealed Cells with Recombination

Electrodes -

SECTION VI

SYSTEM ENGINEERING - (TASK V)

V.1 Evaluation of $\mathrm{zinc}$ Electrode Additives in $20 \mathrm{Ah}$

$\mathrm{Ni}-\mathrm{Zn}$ Cells -

V.2 Alternate Electrolyte Mixes in $20 \mathrm{Al} \mathrm{Ni}-\mathrm{Zn}$ Cells -----191

V.3 Cycling of Cells with PVA Separator and oinc

Additive Variations -

V.4 Cycle Test Data for Cells with Celgard K-306 Separator

and Zinc Additive Variations - 196

V.5 Cycle Data for Cells with $\mathrm{Bi}_{2} \mathrm{O}_{3} \mathrm{Zinc}$ Additive and

Various Separator Systems - 201

V.6 Cycle Performance of Cells with ERC and Commercial

$\mathrm{Ni}(\mathrm{OH})_{2}$ Positive Active Material

V.7 Annual Electric Vehicle Trip Distribution for 75 th

Percentile Operator - 216
\end{abstract}

Page No. $x i$ 
ENERGY RESEARCH CORPORATION

SECTION I

EXECUTIVE SUMMARY

Page No. 1 
- NICKEL ELECTRODE - Nickel electrodes containing active material prepared by the ERC process with $1.5 \% \mathrm{CO}(\mathrm{OH})_{2}$ have yielded over 500 cycles in $100 \%$ DOD testing in 20 Ah size nickel-cadmium cells. In cycling $\mathrm{Ni}-\mathrm{zn}$ cells, zinc compounds in the positive plate considerably. reduced the cycle life. Commercial sources for $\mathrm{Ni}(\mathrm{OH})_{2}$ are being pursued.

- ZINC ELECTRODE - The major function of various additives to the zinc electrode have been identified and have resulted in improved cycle life, reduced shape change and dendritic shorting. A combination of additives is now used in the zinc electrode which improvesthe mechanical strength with regard to resistance to the swelling of the positive electrode, improveswater and electrolyte retention, reduces $\mathrm{n}$ solubility, and reducesdendritic forms of zinc. Electrodes prepared with these additives exhibit lower anodic and cathodic polarization and have shown cycle lives in excess of 200 at 1008 . DOD in 20 Ah size cells. Results obtained from polarization data of single electrodes are being used to formulate a new theory for $\mathrm{zinc}$ shape change. Simply stated, the lower the anodic shift of the open circuit voltage and overvōtâgé auring polarızation the lower the degree of shape change.

- SEPARATOR - The use of cross-linked PVA separator increases the failure of cells by shape change and decreases the incidence of zinc shorting. The use of ERC type composite separators results in a substantial reduction in shape change but poor zinc dendrite stopping ability. Reproducible 
results were obtained in the range of 300 to 400 cycles in 3 Ah size cells.

Multi-component separator systems of dissimilar materials yield longer cycle life compared to simple multi-layer systems comprised of similar materials.

- SEALED CELLS - The potential benefits of sealed cells construction which include zero maintenance and reduced shorting have not been realized in Ni-Zn cells. The predominant failure mechanism in cells is redistribution of electrolyte which results in drying out of the electrodes during cycling. This phenomenon is accelerated by the limited electrolyte quantity required by the sealed cell configuration. The longest lived cells to date have only yielded 30 cycles. Due to budgetary constraints efforts in this area will be discontinued in FY 1981.

- SYSTEM ENGINEERING - A test regime has been established for 250 Ah cells which simulates a pattern of vehicle use based. on trip distributions of $100 \mathrm{miles}$ and under. The initial data obtained from cells which gave only 30 cycles on constant current $80 \%$ DOD cycling showed that almost 13,000 miles could be obtained before the equivalent range dropped to 60 miles. Improved $250 \mathrm{Ah}$ cells with 25 wh/lb energy density have been cycled at the $c / 3$ rate to $80 \%$ DOD yielding 150 cycles, and are presently being tested on the simulated vehicle regime. Large size single positive electrode tests have yielded over $250100 \%$ DOD cycles at the $c / 2$ rate with improved designs. 
ENERGY RESEARCH COAPORATION

These results have been achieved without reconditioning and with periodic water addition the only maintenance procedure employed. 
ENEFEY RESEARER: COABORATION:

\author{
SECTION II \\ NICKEL ELECTRODE DEVELOPMENT \\ FOR NICKEL-ZINC CELLS - (TASK I)
}

i

Page No. 5 


\subsection{INTRODUCTION}

During the past 12 months, work has been in progress to optimize nickel hydrate preparation and the structure of the roll bonded positive electrode. The preparation of nickel hydrate has been directed at using the least amount of cobalt and reducing the number of process steps. The technical investigation has centered on:

- Non-cobalt additives

- Coprecipitated cobalt-nickel hydrate

- Addition of cobalt to nickel hydrate

- Addition of graphite during hydrate preparation

- Treatment of graphite and other graphite sources

- Hydrate preparation using $\mathrm{NaOH}$

- Commercial sources of nickel hydrate

The nickel hydrates were made into positive electrodes using the plastic bonded electrode structure. These electrodes were evaluated in $20 \mathrm{Ah}$ size nickel-cadmium cells to determine voltage characteristics and active material utilization. Following initial screening, the cells were life cycle tested using a two-hour $100 \%$ depth of discharge and a six-hour $110 \%$ charge input to determine capacity maintenance for various positive electrode types.

Tests conducted using 20 Ah nickel-cadmium cells showed that it was possible to make a hydrate with $1.5 \%$ cobalt which met the objectives of this program. The emphasis was changed to reproduce these same results in the nickel-zinc system where the solubility of zinc and dendritic growth influence the behavior of the nickel electrode. 
The test vehicle used was the 250 Ah size, single plate nickel-zinc cell consisting of one positive and two negative plates with a nominal capacity of $20 \mathrm{Ah}$. Initially, commercial PVA was used as the membrane barrier; later, based upon the experience of others, the separator was changed to Celgard K-306, a porous polypropylene film coated with cellulose acetate.

The cycling tests were performed using two different cyclers, one which discharged to $1.20 \mathrm{~V}$ and the other to $0.80 \mathrm{~V}$. In the latter case, the capacity to $1.20 \mathrm{~V}$ was recorded on the monitored cycles.

The initial tests were directed at determining the assembly or test conditions required to obtain full positive plate capacity in the nickel-zinc cell without positive formation. This approach was only partially successful so it was augmented by hydrate preparation adjustments to improve the electrode structure and electrolyte additions to decrease the effect of soluble zinc products on the positive plate. 
ENEREY MLSERACH CGOPSAATISI:

\subsection{TECHNICAL DISCUSSION}

\subsection{ERC $1.5 \%$ COBALT-NICKEL HYDRATE}

At ERC, the preparation of nickel hydrate has been directed at the use of the least amount of cobalt and the fewest process steps. Commercial I hydrate containing $1.5 \%$ cobalt has been used in much of our work because of its availability. For a direçt comparison, $1.5 \%$ cobalt-nickel hydrates were prepared using the ERC WD procedure. These hydrates utilized surfacc concentrated cobalt as well as copreclpltates with 33 and 4 bu excess caustic. In conjuction with these hydrates several graphites were also tested using the $45 \%$ excess caustic hydrate. These include treated Asbury 71.02, (our normal graphite). The aim of the treatment was to make the graphite both wettable and to pre-age it so that it might be more stable to additional oxidation. Two other commercial graphites which were tested using the same hydrate were Lonza $\mathrm{kS}-4 \dot{4}$ and Dixon Air spun 200-08. The former has properties similar to Asbury 7102; the latter represents graphite pulverized with an air jet mill whose particle distribution has a narrower range. These particles have a $10 \mu \mathrm{m}$ average. Except as noted, $20 \mathrm{Ah}$ nickel-cadmium test cells were made using standard procedures. Data for these cells including 503 standard charge-discharge cycles are given in Table I.1.

The formation capacities of these cells were lower than expected, yielding a utilization of $75^{\circ}$ of theoretical. The cyclic capacities however were very stable during the test. The addition of cobalt to neutral nickel hydrate to form 
Table I.I

1.58 COBALT-NICKEL HYDRATE

20 Ah Ni-Cd CELLS

$\begin{array}{llllll}\text { External } & 33 \% & 45 \% & \text { Treated } & \text { Lonza } & \text { Dixon } \\ \text { Cobalt } & \text { Excess } & \text { Excess } & \text { Asbury 7102 } & \text { KS -44 } & \text { 200-08 }\end{array}$

FORMATION CYCLE Cycle 4 at 10 Amps

CELL VOLTAGE

Cycle 1

Cycle 13

Cycle 28

Cycle 55

Cycle 76

Cycle 108

Cycle 159

Cycle 195

Cycle 252

Cycle 299

Cycle 356

Cycle 404

Cycle 431

Cycle 452

Cycle 473

Cycle 503
VOLTAGE AT 1 HOUR - CAPACITY (Ah) TO 1.00/0.70 VOLT

$1.158-18.5 / 18.7 \quad 1.162-19.1 / 19.4 \quad 1.160-18.5 / 18.8 \quad 1.167-19.6 / 19.8 \quad 1.166-18.9 / 19.2 \quad 1.166-19.2 / 19.3$ AUTOMATIC CYCLING.

AT 2 HOUR/ 2 HOURS OR CAPACITY (Ah) TO 0.70 VOLT

$\begin{array}{lllll}1.148 / 0.926 & 1.152 / 1.093 & 1.151 / 1.060 & 1.157 / 1.091 & 1.158 / 1.066 \\ 1.160 / 0.684 & 1.166 / 0.921 & 1.162 / 0.670 & 1.173 / 1.042 & 1.172 / 0.774 \\ 1.157 / 0.674 & 1.162 / 0.886 & 1.161 / 0.692 & 1.174 / 1.100 & 1.172 / 0.774 \\ 1.149 / 0.728 & 1.167 / 0.854 & 1.160 / 0.648 & 1.180 / 1.092 & 1.172 / 0.813 \\ 1.140 / 19.2 & 1.166 / 0.604 & 1.146 / 19.2 & 1.184 / 1.070 & 1.170 / 0.648 \\ 1.122 / 19.3 & 1.143 / 19.3 & 1.128 / 19.2 & 1.178 / 0.887 & 1.166 / 0.638 \\ 1.108 / 19.5 & 1.137 / 19.5 & 1.114 / 19.2 & 1.170 / 0.778 & 1.164 / 0.605 \\ 1.111 / 19.5 & 1.138 / 19.8 & 1.112 / 19.8 & 1.172 / 0.644 & 1.164 / 0.564 \\ 1.104 / 19.8 & 1.136 / 0.598 & 1.108 / 19.7 & 1.170 / 0.637 & 1.160 / 0.560 \\ 1.104 / 0.601 & 1.144 / 0.600 & 1.114 / 19.8 & 1.170 / 0.740 & 1.166 / 0.549 \\ 1.116 / 0.548 & 1.148 / 0.560 & 1.108 / 19.7 & 1.168 / 0.755 & 1.164 / 0.591 \\ 1.113 / 19.8 & 1.150 / 0.568 & 1.084 / 18.8 & 1.164 / 20.0 & 1.165 / 0.537 \\ 1.110 / 19.5 & 1.148 / 0.557 & 1.080 / 18.7 & 1.161 / 19.3 & 1.158 / 19.8 \\ 1.098 / 19.5 & 1.144 / 0.548 & 1.048 / 18.2 & 1.158 / 19.0 & 1.152 / 19.5 \\ 1.101 / 19.3 & 1.136 / 0.510 & 1.046 / 17.2 & 1.153 / 19.0 & 1.130 / 19.3 \\ 1.102 / 19.3 & 1.152 / 0.463 & 1.077 / 17.5 & 1.148 / 18.7 & 1.121 / 17.8\end{array}$

$1.154 / 1.086$

$1.172 / 20.0$

$1.174 / 0.831$.

$1.166 / 19.8$

$1.152 / 19.0$

$1.139 / 18.7$

$1.117 / 18.2$

$1.110 / 17.8$

$1.102 / 17.7$

$1.117 / 17.7$

$1.117 / 17.3$

$1.093 / 16.3$

Note: All results are the average of two cells. 
t:m, .

externally concentrated cobalt does not appear to be beneficial. The $33 \%$ excess caustic hydrate cells are better than those with 45\% and would appear near optimum for the wD procedure. The treatment of graphite was beneficial with an improvement in the cell discharge voltage and capacity. The treatment of the graphite also decreased cell swelling by about 25 용 compared to cells with untreated graphite. The cells fabricated with Lonza graphite were better than those with Asbury graphite and comparable to those with the treated graphite. The cells with Dixon graphite were poorer than both other grolips.

A test was made to compare treated Asbury 7102 and Lonza KS-44 graphites. Both of the treated graphites were used to make electrodes with the same $1.5 \%$ cobalt-nickel hydrate using $33 \%$ excess caustic. The 20 Ah nickel-cadmium test cells utilized standard procedures. The data for these cells ineluding 454 charge-discharge cycles are given in Table I.2

These new cells showed a utilization of $90 \%$ of theoretical in comparison to the previous $75 \%$. It is believed that part of this better utilization is due to normal cell variation in addition to the treated graphite. The cyclic capacities of cells with either treated Asbury 7102 or Lonza KS-44 were stable and equivalent through 400 cycles, after which the cell capacities started to drop off due to the development of soft shorts.

Present data indicate that the use of treated graphite leads to a $5 \%$ improvement in cell capacity due to better utilization. In addition, the discharge curve has a sharper knee and the gradual increase in cell capacity between $1.00 \mathrm{~V}$ and $0.70 \mathrm{~V}$ with cycling at the two hour rate is delayed by 150 cycles. Fage No. 10 
Table I. 2

\section{5\% COBALT-NICKEL HYDRATE TREATED GRAPHITES}

20 Ah Ni-Cd CELLS

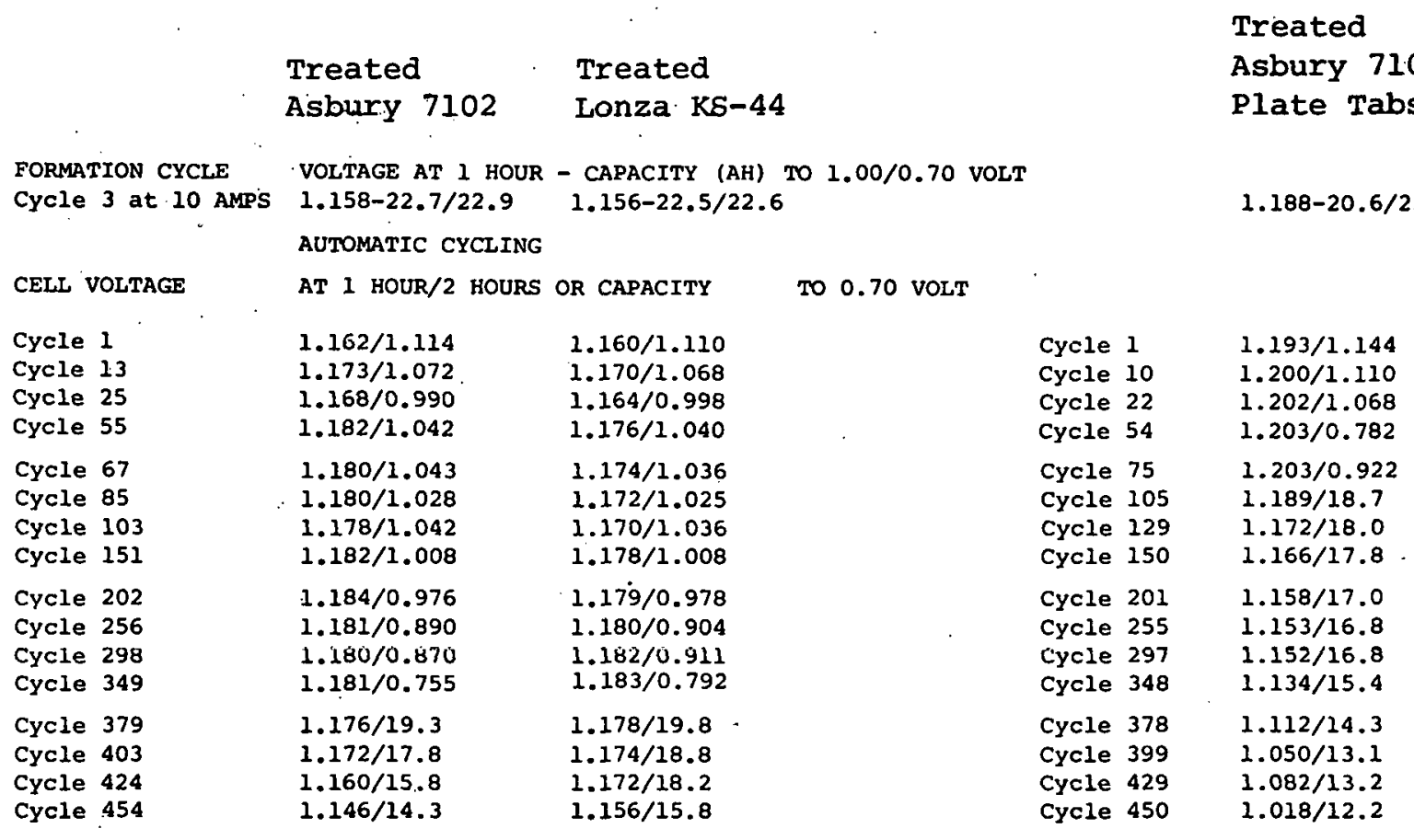

Note: All results are the average of two cells. 


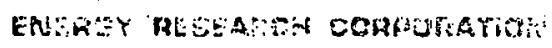

Another set of 20 Ah nickel-cadmium cells was made using the same $1.5 \%$ cobalt-nickel hydrate and treated Asbury graphite. In this case, nickel strip tabs were substituted for the usual wires so that the post connection could be spot welded for better electrical contact. The data for these cells including 450 standard charge-discharge cycles are also given in Table I.2.

The expected improvement in the discharge voltage was obtained as shown by the voltage at one hour. The initial hydrate utilization to $1.0 \mathrm{~V}$ was 808 and tu $0.70 \mathrm{~V}$ 1t excesded yus.

\subsection{GRAPHITE ADDITION DURING HYDRATE PREPARATION}

Experiments were conducted to improve electrode performance by incorporating a portion of the conducting graphite during 58 cobalt-nickel hydrate preparation. If the graphite could be used more effectively, it would be possible to use less and thereby commit a larger portion of the electrode volume to the active hydrate. In the tirst experiments, either 10 or $15 \%$ treated Asbury graphite was added to the precipitation caustic based on the expected yield of graphite plus hydrate by the wD procedure. A portion of the $10 \%$ graphite hydrate was treated as a WDW hydrate to reduce the sulfate content from 1.06 to 0.608 . The addition of cobalt was also varied from a coprecipitate to addition in sequence after the nickel was precipitated as well as being added after the graphite nickel hydrate had been washed to neutral. Positive plates were made by adding additional treated graphite to yield a total of 25\%. Otherwise, the finished 20 Ah cells were made according to standard procedures. The data for these cells as well as 302 standard charge-discharge cycles are given in Table I.3. 
Table I. 3

5\% COBALT-NICKEL HYDRATE'WITH TREATED GRAPHITE

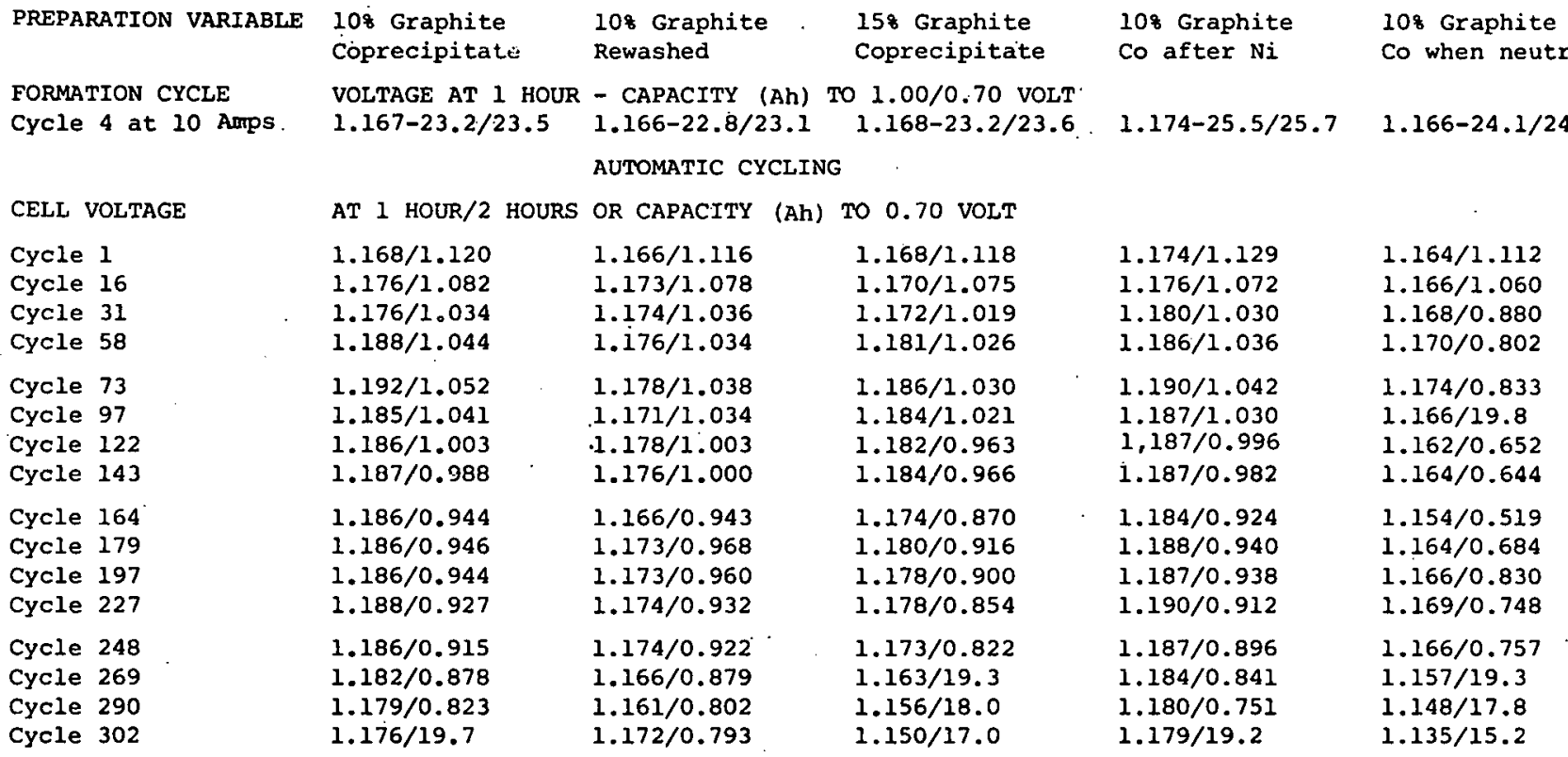

Note: All results are the average of two cells. 


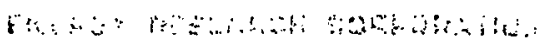

The addition of $15 \%$ rather than $10 \%$ graphite during hydrate preparation does not improve electrode conductivity or cyclic capacity maintenance. The additional washes to decrease the sulfate content below $1 \%$ do lead to improved capacity maintenance during extended cycling. The sequential addition of cobalt after nickel results in initial improved utilization of the hydrate. With cycling, this initial advantage changes to favor coprecipitation of nickel and coualt. The adaition of the cobalt to the nickel hydrate after washing to neutral does not appear to be a viable approach.

Another series of cell tests was conducted with $5 \%$ cobaltnickel hydrate to further define the relationship of graphite addition during hydrate versus electrode preparation. For these tests, treated Asbury graphite was used to make $5 \%$ and $10 \%$ graphite/nickel hydrates as well as in electrode preparatiun. The cobalt was added as a coprecipitate as well as sequentially to the nickel hydrate precipitation to confirm previous results. The total graphite was varied between $30 \%, 25 \%$ and $20 \%$ to determine the minimum requirement for satisfactory cycling. The desired electrode loadings were obtained experimentally by comparing the bulk density (scott volumeter) of the standard (30\% graphite) to the other variations. A listing of the cell formulations made as well as the formation and cyclic capacities is given in Table I.4.

The cells were given eight formation cycles to develop stable capacities prior to cycling. They were then given 151 standard charge-discharge cycles. The sequential addition of cobalt showed better initial utilization of the hydrate than 
Table. I. 4

EFFECT OF ADDED GRAPHITE ON $5 \%$ COBALT-NICKEL HYDRATE

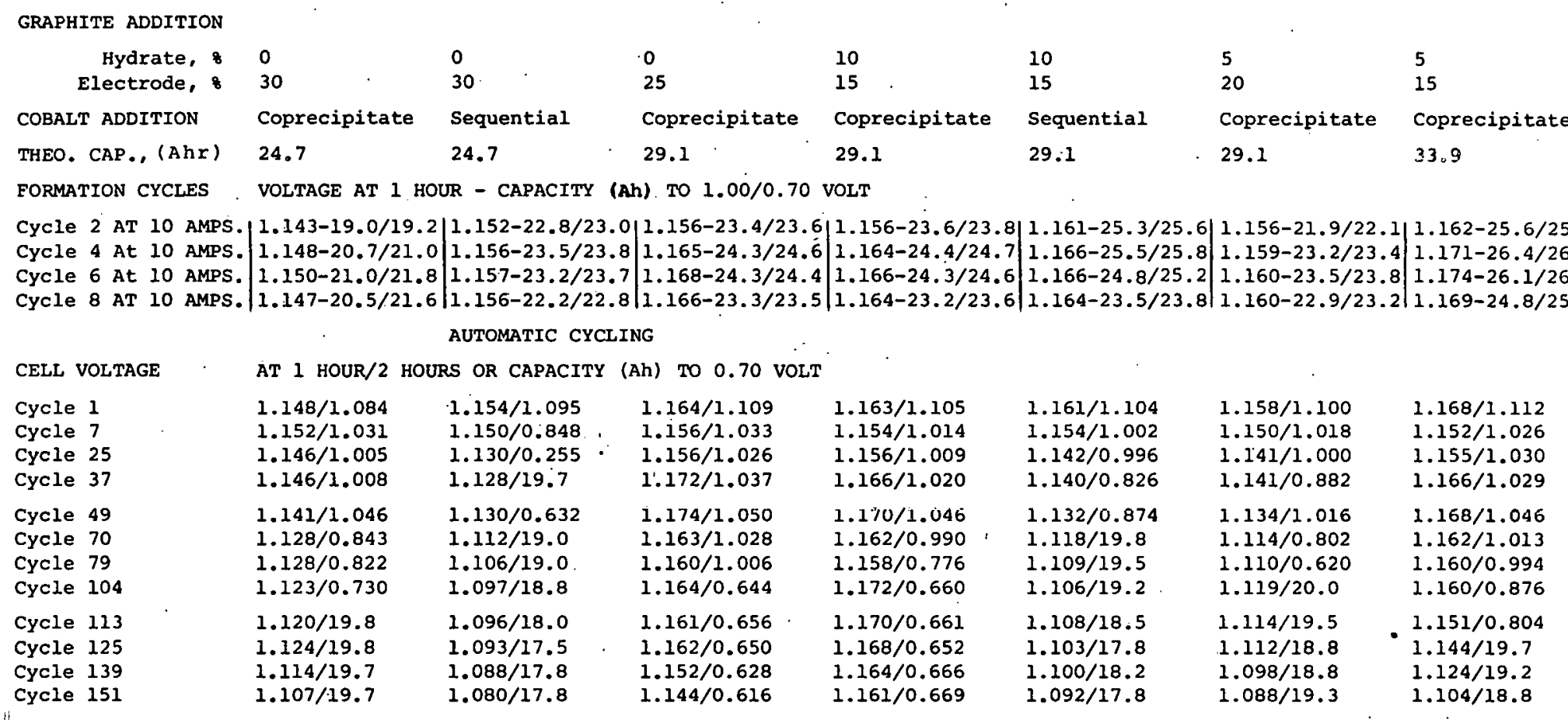

Note: All results are the average of two cells. 
the coprecipitate. This better utilization was not maintained during cycling in agreement with previous results. Decreasing the graphite content from 30 to $25 \%$ leads to an increase in cell capacity even though the utilization is decreased. Much of this increased capacity was maintained during cycling. The benefit of adding a portion of the graphite during precipitation has still not been confirmed. The scatter of the results, with a $10 \%$ addition being better and a $5 \%$ poorer, will require a re-evaluation of this technique. This work on the addition of graphite during hydrate preparation wàs eermilldted to concentrate on the study of the nickel hydrate performance in nickel-zinc cells.

\subsection{STANDARD VS CELLOPHANE WRAP}

In $20 \mathrm{Ah} \mathrm{Ni-Cd}$ test cells, the separator system consists of a $7 \mathrm{mil}$ Pellon bag on both the positive and negative plates. With this system, one of the modes of failure is the penetration of cadmium through the separator and the development of soft shorts. A possible solution to this problem is the use of a membràne barrier. Ilentical elcctrodes were made into test cells having two layers of $5 \mathrm{mil}$ Pellon on the positive plate and $\mathrm{a}$ U-wrap with $3 \mathrm{mil}$ cellophane on the negative plate. Four 20 Ah $\mathrm{Ni}-\mathrm{Cd}$ test cells were made with 108 cobalt-nickel hydrate using each separator confirguration. The data for these cells together with 405 standard charge-discharge cycles are given in Table I.5. Up to 350 cycles, the cells without cellophane were superior in voltage and cyclic capacity maintenance. After this point, these cells began to develop soft shorts that led to a 
Table I. 5

STANDARD VS. CELLOPHANE WRAP

ERC $10 \& \mathrm{CO}-\mathrm{Ni}(\mathrm{OH}) 2 ; 20$ AH Ni-Cd CELLS

STANDARD WRAP

CELLOPHANE WRAP

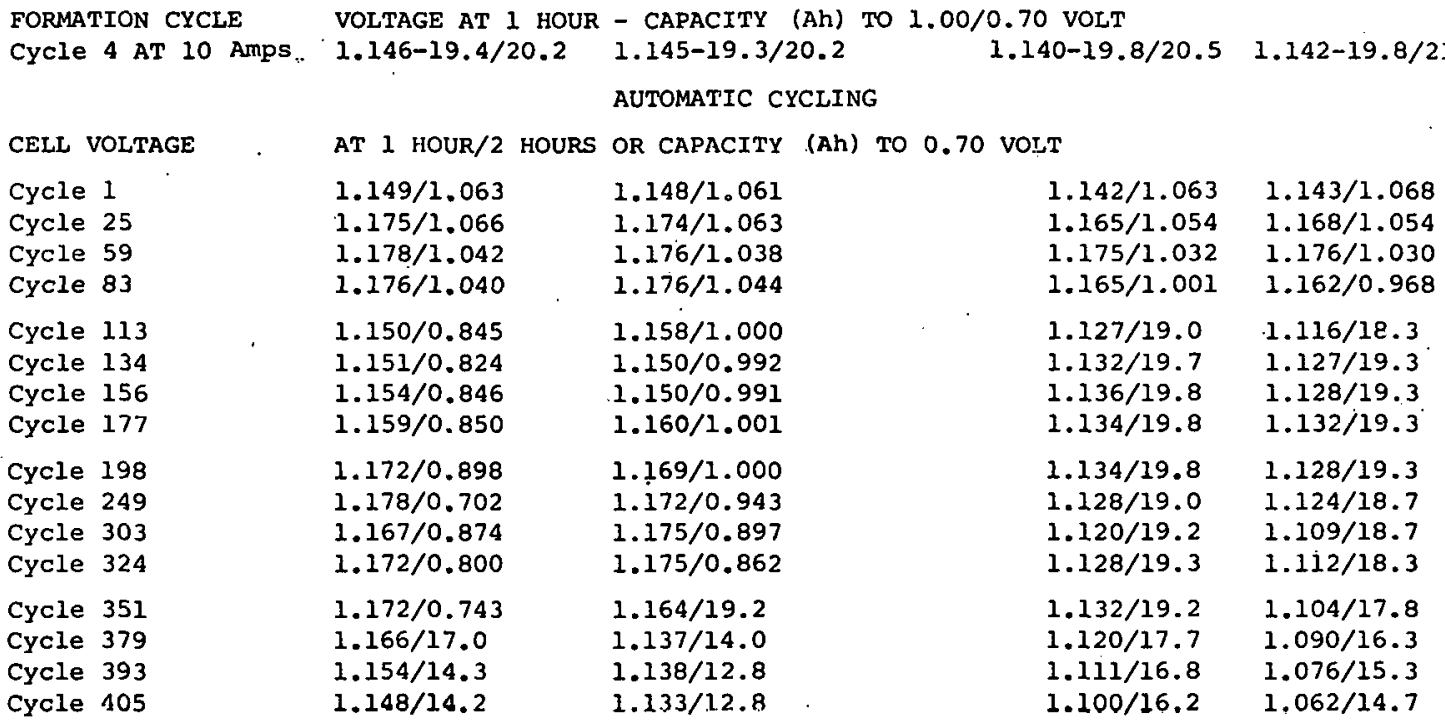

Note: All results are the average of two cells. 
more rapid decrease in capacity. Although the development of soft shorts in this case was earlier than expected, it is evident that a membrane barrier will aid in preventing them.

\section{4 SODIUM HYDROXIDE ADDITION}

In the nickel-cadmium pocket plate industry, sodium hydroxide is primarily used for hydrate preparation instead of $\mathrm{KOH}$ to achieve cost effectiveness. In addition, residual sodium ions in the nickel hydroxide lattice are reported to act similar to lithium in promoting cyclic capacity maintenance. coprecipitated $5 \%$ cobalt-nickel hydrate was prepared using $50 \%$ sodium hydroxide by the WD procedure. In addition, several tests were conducted using a partial graphite addition during hydrate preparation. In one experiment, a $10 \%$ graphite-hydrate was made by adding graphite to the caustic. In a second experiment, the graphite was first wet with $10 \%$ of the cobalt-nickel solution before adding the raustic. After this step, the remainder of the cobalt-nickel solution was added to make a $10 \%$ graphitehydrate. All of these hydrates were made into 20 Ah nickelcadmium test cells by adding the appropriato amount of treated graphite to the positive plates so that all active material contained $30 \%$ graphite. The data for these cells including 352 standard charge-discharge cycles are given in Table T. 6.

The formation data show that the cells with graphite/

nickel hydrate had a large capacity increment between 1.00 and $0.70 \mathrm{~V}$. In addition, the voltage level of these cells was suppressed during cycling. The cells with conventional sodium hyaroxide coprecipitated hydrate did perform satisfactorily 
TABLE I. 6

58 SODIUM HYDROXIDE

58 COBALT-NICKEL HYDRATE

20 Ah Ni-Cd CELLS

\begin{tabular}{|c|c|c|c|}
\hline \multirow[b]{2}{*}{$\begin{array}{l}\text { FORMATION CYCLE } \\
\text { CYCle } 5 \text { AT } 10 \text { Amps }\end{array}$} & $\begin{array}{l}\text { Coprecipitate } \\
\mathrm{Ni}+\mathrm{Co}\end{array}$ & Graphite to $\mathrm{KOH}$ & $\begin{array}{l}\text { Ni to Graphite, } \\
\text { then } \mathrm{KOH}\end{array}$ \\
\hline & \multicolumn{3}{|c|}{ 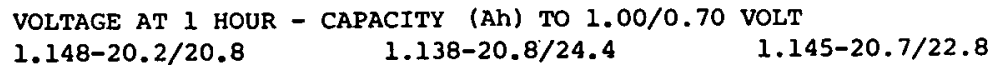 } \\
\hline & AUTOMATIC & & \\
\hline CELL VOLTAGE & AT 1 HOUR/2 HOURS & PACITY $(\mathrm{Ah})$ TO 0. & \\
\hline $\begin{array}{l}\text { Cycle } 1 \\
\text { Cycle } 25 \\
\text { Cycle } 55 \\
\text { Cycle } 76\end{array}$ & $\begin{array}{l}1.146 / 1.102 \\
1.156 / 1.036 \\
1.172 / 0.890 \\
1.176 / 0.776\end{array}$ & $\begin{array}{l}1.132 / 1.095 \\
1.128 / 1.035 \\
1.122 / 18.8 \\
1.120 / 18.2\end{array}$ & $\begin{array}{l}1.134 / 1.095 \\
1.131 / 1.032 \\
1.113 / 18.7 \\
1.114 / 17.3\end{array}$ \\
\hline $\begin{array}{ll}\text { Cycle } & 96 \\
\text { Cycle } 127 \\
\text { Cycle } 150 \\
\text { Cycle } 183\end{array}$ & $\begin{array}{l}1.176 / 0.746 \\
1.176 / 0.684 \\
1.178 / 0.682 \\
1.172 / 19.2\end{array}$ & $\begin{array}{l}1.109 / 17.8 \\
1.102 / 16.8 \\
1.120 / 19.3 \\
1.118 / 18.7\end{array}$ & $\begin{array}{l}1.108 / 17.2 \\
1.088 / 16.3 \\
1.108 / 19.7 \\
1.104 / 18.7\end{array}$ \\
\hline $\begin{array}{l}\text { Cycle } 204 \\
\text { Cycle } 222 \\
\text { Cycle } 256 \\
\text { Cycle } 277\end{array}$ & $\begin{array}{l}1.176 / 0.710 \\
1.174 / 0.708 \\
1.169 / 0.695 \\
1.164 / 19.7\end{array}$ & & \\
\hline $\begin{array}{l}\text { Cycle } 298 \\
\text { Cycle } 321 \\
\text { Cycle } 343 \\
\text { Cycle } 352\end{array}$ & $\begin{array}{l}1.151 / 19.8 \\
1.153 / 17.2 \\
1.128 / 15.7 \\
1.113 / 15.3\end{array}$ & & \\
\hline
\end{tabular}




\section{ENERGY RESEARCH CORPORATION}

and it should be possible to substitute sodium hydroxide for potassium hydroxide for cost effectiveness.

\subsection{COMPERCIAL NI HYDRATE I: EFFECT OF PARTICLE SIZE}

Previous experiments on the effect of nickel hydrate particle size were conducted by classifying ERC $10 \%$ cobaltnickel hydrate into four fractions: These tests showed that the more coarse fractions produced cells having the best cycling characteriatica. To determine whether the oame was true for the commercial hydrate I, a 50 pound portion was classified into two equal fractions. Coulter counter measurements showed an initial particle size of $16.2 \mu \mathrm{m}$ that was divided into a coarse fraction of 24 and a finer fraction of $9.6 \mu \mathrm{m}$. These fractions were made into $20 \mathrm{Ah} \mathrm{Ni}-\mathrm{Cd}$ cells using both regular and treated Asbury graphites. The cycle data for these cells are given in Table I.7.

The formation cycles showed a small improvement with the coarse hydrate. In both instances there was an additional improvement with treated graphite. None of the cells exhibited the desired cyclic stability. The scatter of the results makes meaningful interpretation difficult, but it does appear that there was no effect due to particle size and the cells with regular graphite held üp better during cycling.

2.6 COMMERCIAL NI HYDRATE.I: PREFORMED PLATES

Five 20 Ah nickel-cadmium cells were made using preformed. (April 1979) commercial $\mathrm{Ni}$ hydrate I to determine their behavior on cycling. The formation utilization of the cells was less than $75 \%$ of theoretical and the cells did not cycle well. 
Table I.7

COMMERCIAL HYDRATE: I COARSE AND FINE HYDRATE

20 Ah Ni-Cd CELLS

Coarse. Fine

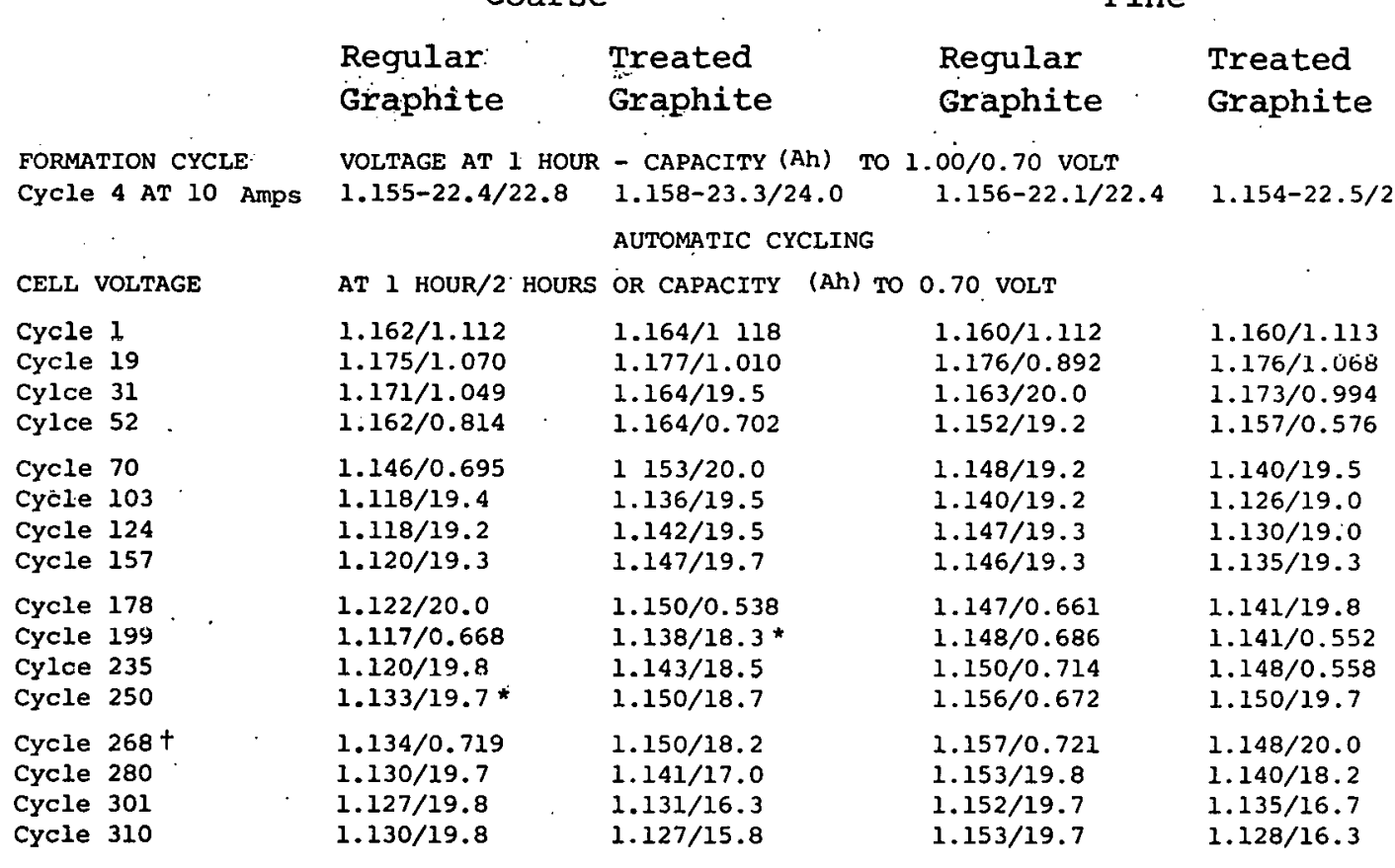

* Results are the average of two cells except those

$t$ Cycler shut down for power changeover prior to this cycle. 
This test was repeated to determine a possible reason for the behavior. The data for five new cells including 183 standard charge-discharge cycles are given in Table I.8. In addition, the average data of the previous cells are presented for ready comparison. The new formation data are better, having a utilization of $80 \%$. The cyclic capacities have not been stable and these cells also fail to duplicate old unformed cells, some of which gave over 400 cycles before falling below $20 \mathrm{Ah}$.

\subsection{COMMERCIAL NI HYDRATE I (MAY 1980)}

A new supply of commercial $\mathrm{Ni}$ hydrate I (May 1980) was reçeived, Their new specification calls for $0.6 \%$ rather than $1.5 \%$ cobalt. An agreement was made to supply ERC with $1.5 \%$ cobalt hydrate; the new $0.6 \%$ cobalt hydrate would be pretested prior to entensive use at ERC. The $20 \mathrm{Ah} \mathrm{Ni-Cd}$ test cells were fabricated with nickel hydrates containing 0.6 and $1.5 \%$ cobalt as well as ERC washed $\mathrm{Ni}(\mathrm{OH})_{2}$ containing $1.5 \%$ cobalt. The rewashing of the hydrate removes traces of free alkali and decreases the sulfate content from 1.5 to under 1\%. The data for these cells are given in Table. I.9.

The formation results for these cells are normal with $0.6 \%$ cobalt hydrate having the expected higher discharge voltage. The small difference in cyclic capacity maintenance favors the use of $1.5 \%$ cobalt. The washing of the hydrate improves the discharge voltage, but its effect on cell capacity to $0.70 \mathrm{~V}$ appears marginal. A comparison to the cyclic performance of previous unformed cells shows that the new cells are generally poorer. The results indicate that commercial $\mathrm{Ni}$ hydrate I con- 
Table I.8

COMMERCIAL NI HYDRATE I PREFORMED PLATES

20 Ah NI-CD CELLS
No. 1
No. 2
No. 3
No. 4
No. 5
Previous Cells (Av.5)

FORMATION CYCLES VOLTAGE AT 1 HOUR - CAPACITY TO $1.00 / 0.70$ VOLT

Cycle 2. AT 10 Amps 1.143-19.3/20.8 1.143-20.2/21.7 1.142-20.0/21.5 1.139-20.0/20.5 1.143-20.0/20.7

Cycle 4 At 10 Amps $1.139-19.3 / 20.81 .140-20.2 / 21.71 .139-20.2 / 21.71 .136-20.2 / 21.01 .140-20.3 / 21.5$

AUTOMATIC CYCLING

CELL VOLTAGE

Cycle 1

Cŷcle 7

Cycle 16

Cycle 25

AT 1 HOUR/2 HOURS OR CAPACITY (Ah) TO 0.70 VOLT

Cycle 34

Cycle 46

Cycle 55

Cycle 76

$1.142 / 1.101$

$1.140 / 1.101$.

$1.128 / 1.098$

$1.150 / 19.7$

$1.143 / 19.7$

$1.142 ; 19.7$

$1.135 / 1.098$

$1.142 / 19.5$

$1.135 / 19.3$

$1.135 / 19.3$

$1.140 / 19.8$

$1.133 / 19.5$

$1.139 / 1.100$

$1.134 / 19.7$

$1.131 / 18.8$

$1.129 / 19.0$

1. $145 / 20.0$

$1.131 / 19.0$

$1.126 / 19.5$

$1.125 / 19.7$

$1.136 / 19.5$

$1.132 / 20.0$

$1.127 / 19.3$

$1.122 / 18.2$

$1.120 / 18.5$

$1.131 / 19.2$

$1.124 / 19.5$

$1.123 / 18.5$

$1.128 / 19.8$

$1.121 / 0.990$

$1.119 / 19.3$

$1.113 / 19.3$

$1.126 / 18.3$

$1.123 / 19.0$

$1.123 / 18.0$

$1.120 / 17.7$

$1.121 / 19.5$

$1.121 / 18.5$

$1.124 / 17.8$

$1.121 / 18.5$

$1.112 / 17.2$

$1.118 / 17.8$

$1.122 / 17.5$

$1.104 / 15.7$

$1.109 / 15.7$

$1.122 / 16.5$

$1.100 / 14.8$

$1.114 / 16.5$

$1.097 / 14.8$

$-1-$

$1.112 / 17.5$

$1.110 / 17.3$

$1.097 / 15.2$

$1.116 / 17.2$

$1.121 / 16.7$

$1.110 / 18.3$

$1.103 / 17.5$

$1.112 / 17.5$

$1.115 / 16.8$

$1.092 / 15.2$

$1.102 / 16.0$

$1.073 / 15.0$

$1.117 / 16.5$

$1.098 / 14.8$

$1.111 / 15.5$

$1.086 / 15.0$

$1.115 / 16.8$

$1.095 / 13.8$

$1.091 / 14.0$

$1.103 / 16.3$

$1.072 / 15.5$

$1.107 / 16.3$

$1.109 / 16.0$

$1.104 / 16.3$

$\begin{array}{ll}\text { Cycle 1 } & 1.165 / 19.4 \\ \text { Cycle 4 } & 1.165 / 18.8 \\ \text { Cycle 19 } & 1.134 / 18.2 \\ \text { Cycle 25 } & 1.122 / 18.0 \\ \text { Cycle 31 } & 1.113 / 18.0 \\ \text { Cycle 40 } & 1.114 / 18.5 \\ \text { Cycle 47 } & 1.106 / 18.0\end{array}$

Note: Previous data are the average of five NIFE test cells.

Table. I. 9

COMMERCIAL NI HYDRATE I, MAY 1980

20 AH NI-CD CELLS

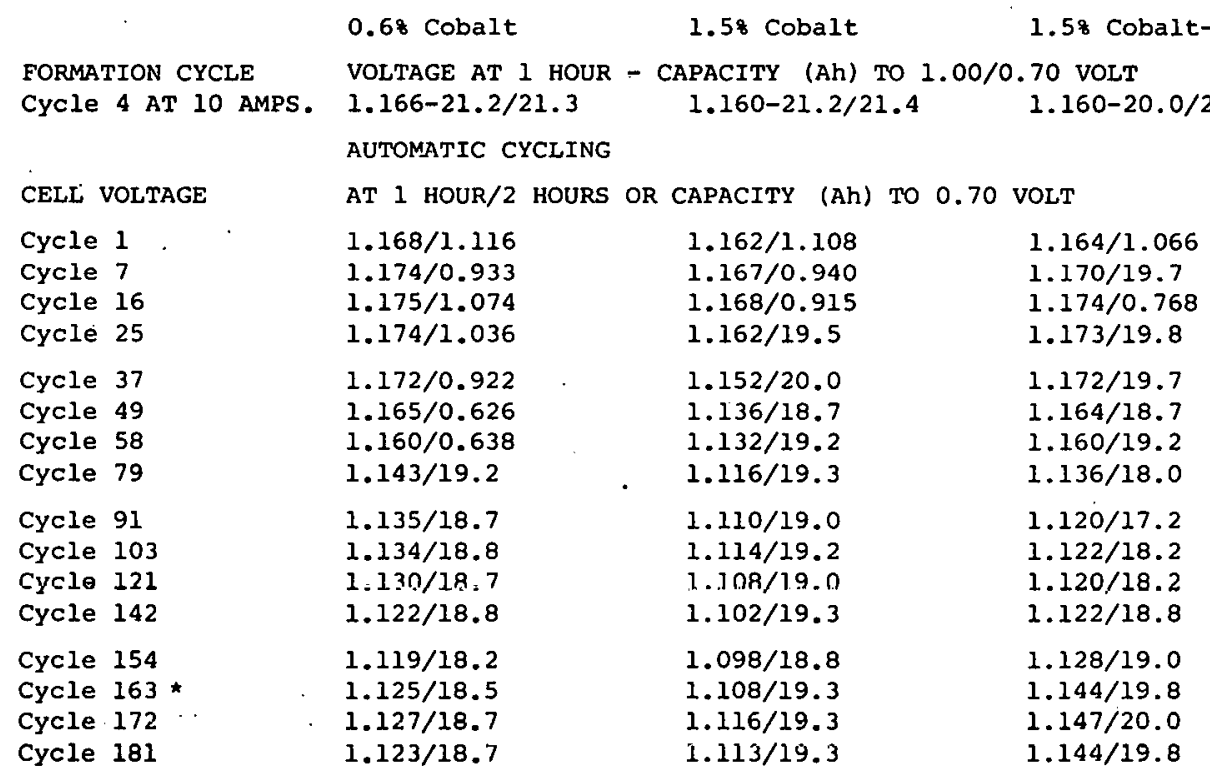

* Cycler shut down prior to this discharge due to power supply. 
taining $0.6 \%$ cobalt can be used for our work with only a minimal performance change.

\subsection{COMMERCIAL NICKEL HYDRATES II}

A cooperative effort has been made with various producers of nickel compounds to develop alternate sources of nickel hydrate. Two commercial samples of nickel hydrate II made from nickel chloride were received and the samples were designated A8078 and A8080, the latter being a portion of the former subjected to an additional WD cycle to decrease the chloride content from 0.09 to $0.02 \%$. Sample A8078 was very coarse and extensive grinding was required to screen material through $500 \mu \mathrm{m}$ openings to make a suitable layer. A8080 required only minimal grinding to pass through a $1100 \mu \mathrm{m}$ opening screen. In both cases, approximately $60 \%$ of the final material would not pass through a 200 mesh $(75 \mu \mathrm{m})$ screen.

Twenty Alı Ni-Cd test cells weite made willi these hydrates using standard procedures. The cells were subjected to 252 standard charge-discharge cycles as given in Table I.10. The hydrate utilization was $70 \%$ of theoretical and improvement will require adjustment of the hydrate or electrode preparation. The cyclic capacity was stable after the initial decrease in capacity.

Nickel chloride received from commercial source II was converted into the hydroxide at ERC using the WD procedure. No difficulties were experienced in its preparation and the 
Table I. 10

COMMERCIAL NICKEL HYDRATES II $1008 \mathrm{Ni}(\mathrm{OH})_{2}$; 20 Ah Ni-Cd CELLS

A8078 A8080 ERC Chloride Borate

FORMATION CYCLE VOLTAGE AT I HOUR - CAPACITY (Ah) TO 1.00/0.70 VOLT

Cycle 4 AT 10 AMPS.1.140-17.9/18.1 1.138-18.3/18.3 $1.145-19.2 / 19.5$

$1.132-18.7 / 22.7$

AUTOMATIC CYCLING

CELL VOLTAGE AT 1 HOUR/2 HOURS OR CAPACITY (Ah) TO 0.70 vOLT

\begin{tabular}{|c|c|c|c|c|c|c|}
\hline $\begin{array}{l}\text { Cycle } \\
\text { Cycle } \\
\text { Cycle } \\
\text { Cycle }\end{array}$ & $\begin{array}{l}1 \\
25 \\
59 \\
71\end{array}$ & $\begin{array}{l}1.136 / 19.8 \\
1.152 / 19.7 \\
1.130 / 18.8 \\
1.124 / 18.3\end{array}$ & $\begin{array}{l}1.138 / 0.936 \\
1.138 / 19.3 \\
1.115 / 18.0 \\
1.106 / 17.7\end{array}$ & $\begin{array}{l}\text { Cycle } \\
\text { cycle } \\
\text { Cycle } \\
\text { Cycle }\end{array}$ & $\begin{array}{l}1 \\
10 \\
19 \\
31\end{array}$ & $\begin{array}{l}1.144 / 1.088 \\
1.158 / 1.021 \\
1.152 / 0.994 \\
1.132 / 19.0\end{array}$ \\
\hline $\begin{array}{l}\text { Cycle } \\
\text { Cycle } \\
\text { Cycle } \\
\text { Cycle }\end{array}$ & $\begin{array}{l}92 \\
113 \\
134 \\
156\end{array}$ & $\begin{array}{l}1.125 / 17.5 \\
1.096 / 16.3 \\
1.120 / 17.2 \\
1.131 / 17.5\end{array}$ & $\begin{array}{l}1.104 / 15.7 \\
1.064 / 15.7 \\
1.077 / 14.8 \\
1.074 / 15.2\end{array}$ & $\begin{array}{l}\text { Cycle } \\
\text { Cycle } \\
\text { Cycle } \\
\text { Cycle }\end{array}$ & $\begin{array}{l}49 \\
79 \\
100 \\
120\end{array}$ & $\begin{array}{l}1.140 / 0.316 \\
1.150 / 0.674 \\
1.158 / 0.546 \\
1.157 / 0.553\end{array}$ \\
\hline $\begin{array}{l}\text { Cycle } \\
\text { Cycle } \\
\text { Cycle } \\
\text { Cycle }\end{array}$ & $\begin{array}{l}165 \\
177 \\
198 \\
207\end{array}$ & $\begin{array}{l}1.130 / 17.7 \\
1.135 / 17.7 \\
1.132 / 18.2 \\
1.128 / 17.8\end{array}$ & $\begin{array}{l}1.088 / 14.0 \\
1.092 / 14.7 \\
1.095 / 14.8 \\
1.104 / 14.0\end{array}$ & $\begin{array}{l}\text { Cycle } \\
\text { Cycle } \\
\text { Cycle } \\
\text { Cycle }\end{array}$ & $\begin{array}{l}151 \\
171 \\
204 \\
225\end{array}$ & $\begin{array}{l}1.144 / 0.376 \\
1.099 / 0.496 \\
1.052 / 0.353 \\
0.862 / 19.8\end{array}$ \\
\hline $\begin{array}{l}\text { Cycle } \\
\text { Cycle } \\
\text { Cycle } \\
\text { Cycle }\end{array}$ & $\begin{array}{l}219 \\
228 \\
240 \\
252\end{array}$ & $\begin{array}{l}1.122 / 17.8 \\
1.127 / 17.5 \\
1.126 / 17.5 \\
1.126 / 17.2\end{array}$ & $\begin{array}{l}1.121 / 15.2 \\
1.121 / 16.2 \\
1.114 / 15.3 \\
1.114 / 15.5\end{array}$ & $\begin{array}{l}\text { Cycle } \\
\text { Cycle } \\
\text { Cycle } \\
\text { Cycle }\end{array}$ & $\begin{array}{l}255 \\
276 \\
297 \\
308\end{array}$ & $\begin{array}{l}0.883 / 18.5 \\
1.013 / 17.5 \\
0.975 / 14.8 \\
0.592 / 14.5\end{array}$ \\
\hline
\end{tabular}

Cycle $1 \quad 1.128 / 0.989$

Cycle $10 \quad 1.111 / 18.2$

Cycle $19 \quad 1.094 / 18.0$

Cycle 31, $1.077 / 19.2$

Cycle $49 \quad 1.102 / 17.0$

Cycle $58 \quad 1.105 / 16.2$

Cycle $79 \quad 1.081 / 18.3$

Cycle $91 \quad 1.082 / 16.3$

Cycle $100 \quad 1.057 / 13.5$

Cycle $111 \quad 1.047 / 12.7$

Cycle $1201.071 / 13.2$

Cyclẹ $1421.045 / 12.2$

Page No. 25 


\section{ENERGY RESEARCH CORPORATION}

final hydrate contained $1.8 \%$ chloride. The 20 Ah Ni-Cd test cells were made using standard procedure. The data for 308 standard charge-discharge cycles are given in Table 1.10. The best cell gave over 200 cycles before the capacity went below $20 \mathrm{Ah}$, which is the best performance of a non-additive Ni-Cd cell produced under this program. The manufacturer's analysis listed only 4 ppm of cobalt in the initial salt, thereby eliminating cobalt as the reason for the improved cycling.

Commercial $\mathrm{Ni}$ hydrate II also supplied a nickel hydrate prepared from nickel borate. The data for this 20 Ah N.i-Cd test cell are presented in Table 1.10. In this case, there was a gradual loss of cyclic capacity.

\subsection{COMMERCIAL NICKEL HYDRATES III}

A third company supplied two samples of nickel hydrate for evaluation. One was trivalent nickel oxide to which they added $25 \%$ graphite. In making the electrodes, $30 \%$ Asbury graphite was added to the former for conductivity while to the latter only the binder was added. The assembly of the $20 \mathrm{Ah} \mathrm{Ni-Ca} \mathrm{cells} \mathrm{was} \mathrm{according} \mathrm{to} \mathrm{standard} \mathrm{procedures.} \mathrm{The}$ data for these cells including 181 standard charge-discharge cycles are given in Table I.ll.

The formation cycles showed a depressed discharge voltage level in comparison to the usual non-cobalt containing cella. In particular, the hydrate containing graphite cells did not have a sharp knee in the discharge curve as evidenced by a large capacity difference between the 1.00 and $0.70 \mathrm{~V}$ endpoints. 
Table I.1I

OTHER NICKEL HYDRATES

20 AH NI-CD CELLS

\section{Commercial Ni Hydrate III \\ Oxidized \\ Oxidized \\ Nickel \\ Nickel \\ w/graphite}

$\begin{array}{lr}\text { THEORETICAL CAP., AH } & 26.0 \\ \text { FORMATION CYCLE } & \text { VOLTAGE AT } \\ \text { Cycle 2 AT 10 AMPS } & 1.136-18.5 \\ \text { Cycle 4 AT 10 AMPS } & 1.140-19.9 / 2 \\ & \text { AUTOMA } \\ \text { CELL VOLTAGE } & \text { AT 1 HOUR/2 } \\ \text { Cycle 1 } & 1.138 / 19.8 \\ \text { Cycle 7 } & 1.145 / 0.896 \\ \text { Cycle 16 } & 1.142 / 0.854 \\ \text { Cycle 25 } & 1.134 / 19.7 \\ \text { Cycle 49 } & 1.112 / 18.7 \\ \text { Cycle 70 } & 1.100 / 18.3 \\ \text { Cycle 91 } & 1.103 / 18.8 \\ \text { Cycle 103 } & 1.107 / 19.2 \\ \text { Cycle 112 } & 1.104 / 18.8 \\ \text { Cycle 121 } & 1.104 / 19.3 \\ \text { Cycle 133 } & 1.097 / 18.8 \\ \text { Cycle } 142 & 1.105 / 19.5 \\ \text { Cycle 154 } & 1.100 / 19.3 \\ \text { Cycle 163 } & 1.101 / 19.3 \\ \text { Cycle 172 } & 1.102 / 19.2 \\ \text { Cycle } 181 & 1.098 / 19.0\end{array}$

30.6

\section{$1.101-16.2 / 23.1$}

$1.136-20.4 / 23.5$

TTOMATIC CYCLING
Commercial Ni Hydrate IV

ERC WD

5\% Cobalt

24.7

T

$1.148-19.8 / 20.3$

Note: All results are the average of two cells.

*Cracked cases repaired. Cells not cycled for 21 days.

tone cracked case repaired.

Cycle 1

Cycle $19 \quad 1.170 / 1.054$

Cycle $49 \cdot 1.156 / 1.060$

Cycle $79 \quad 1.167 / 1.049$

Cycle $100 \quad 1.183 / 1.024$

Cycle $151 \quad 1.182 / 1.016$

Cycle 154* 1.192/0.955,

Cycle $181 \quad 1.192 / 0.974$

Cycle $2051.194 / 0.969$

Cycle $226 \quad 1.192 / 0.931$

Cycle $247 \quad 1.182 / 0.943$

Cycle $277 \quad 1.176 / 0.853$

Cycle $299 \quad 1.184 / 0.806$

Cycle $309 \quad 1.178 / 0.886$

Cycle $327 \quad 1.186 / 0.888$

Cycle $348 \quad 1.184 / 0.862$ 


\section{ENERGY RESEARCH CORPORATION}

During automatic cycling, the depressed voltage has continued. The utilization of the active material and cyclic capacity stability have been marginal.

\subsection{COMMERCIAL NICKEL HYDRATE IV}

A fourth company supplied a 5\% cobalt-nickel hydrate made according to the ERC WD procedure. This hydrate required the normal grinding to make $20 \mathrm{Ah} \mathrm{Ni-Cd}$ test cells by standard procedures. These cells have had 348 standard charqe-discharge cycles and the data are given in Table I.11. The cells have shown good cyclic capacity stability.

\subsection{NICKEL-ZINC VS NICKEL-CADMIUM PERFORMANCE}

In an attempt to determine the effect of the microporous barrier on the mass transport of the electrolyte, the same hydrate was used to make nickel-zinc and nickel-cadmium cells. Identical ERC $1.5 \%$ cobalt-nickel hydrate plates were fabricated into a nickel-zinc cell with PVA, nickel-cadmium cell with FVA and nickel-cadmium cell without PVA. For'consistency, these cells were cycled to $0.8 .0 \mathrm{~V}$ çut-off noting the $1.20 \mathrm{~V}$ endpoint for the nickel-zinc and $1.0 \mathrm{~V}$ for the nickel-cadmium cells. The data for these cells are given in Table I.12.

The nickel-zinc cell initially had a small increase in capacity with cycling before the capacity decreased. Figure I.l shows the effect of cycling on the development. of a second plateau in the nickel-zinc cell leading to a decrease in cell capacity. Theories proposed for this behavior include blocking of the positive plate pores by $z$ inc oxide and electrode delamination 
FIGURE I.I

EFFECT OF CYCLING 250 AH SINIGLE PLATE NI-ZN CELL

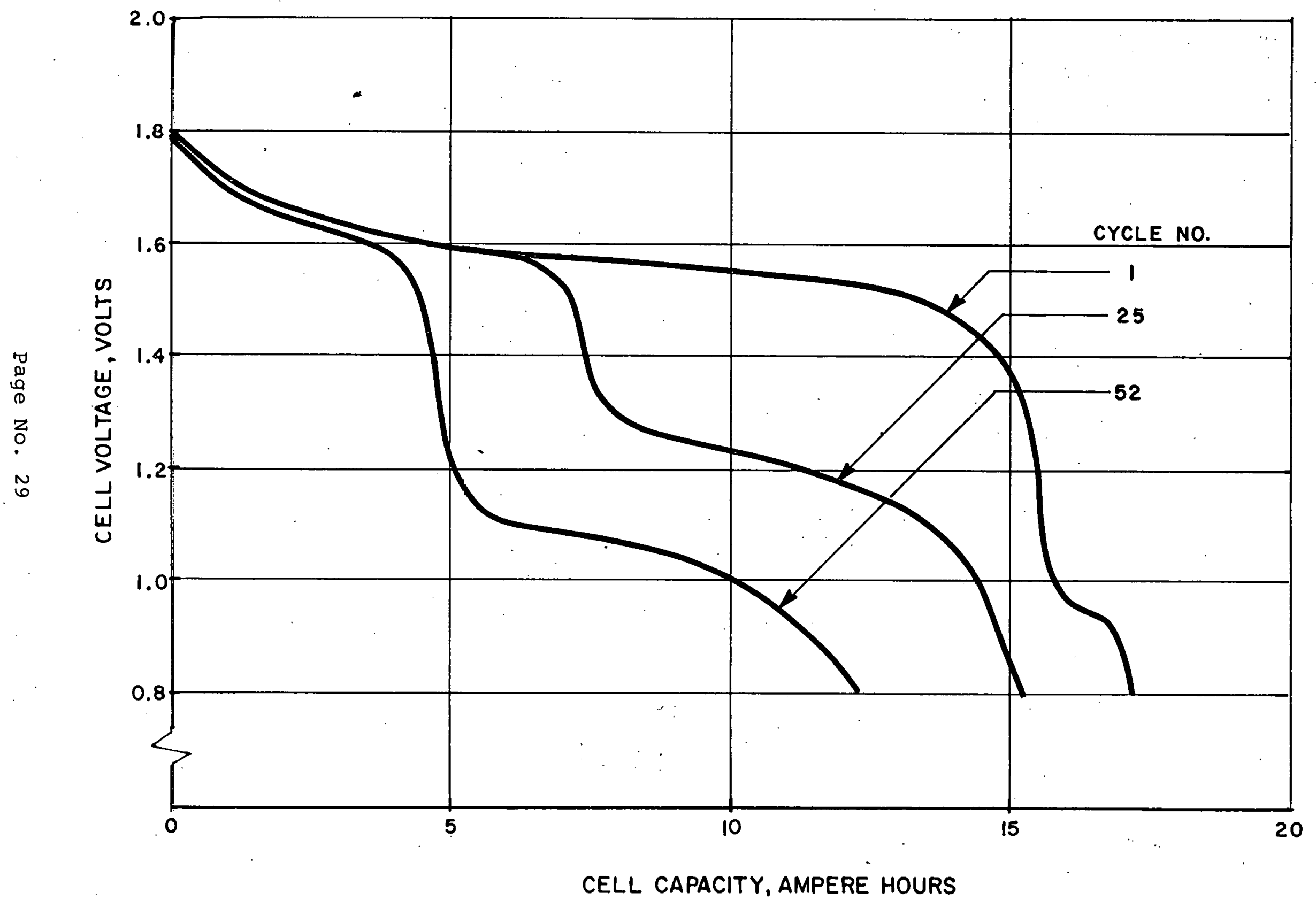


Table I.12

NICKEL-ZINC VS. NICKEL-CADMIUM

ERC 1.58 COBALT-NICKEI

250 aH SINGLE PLATE CELL

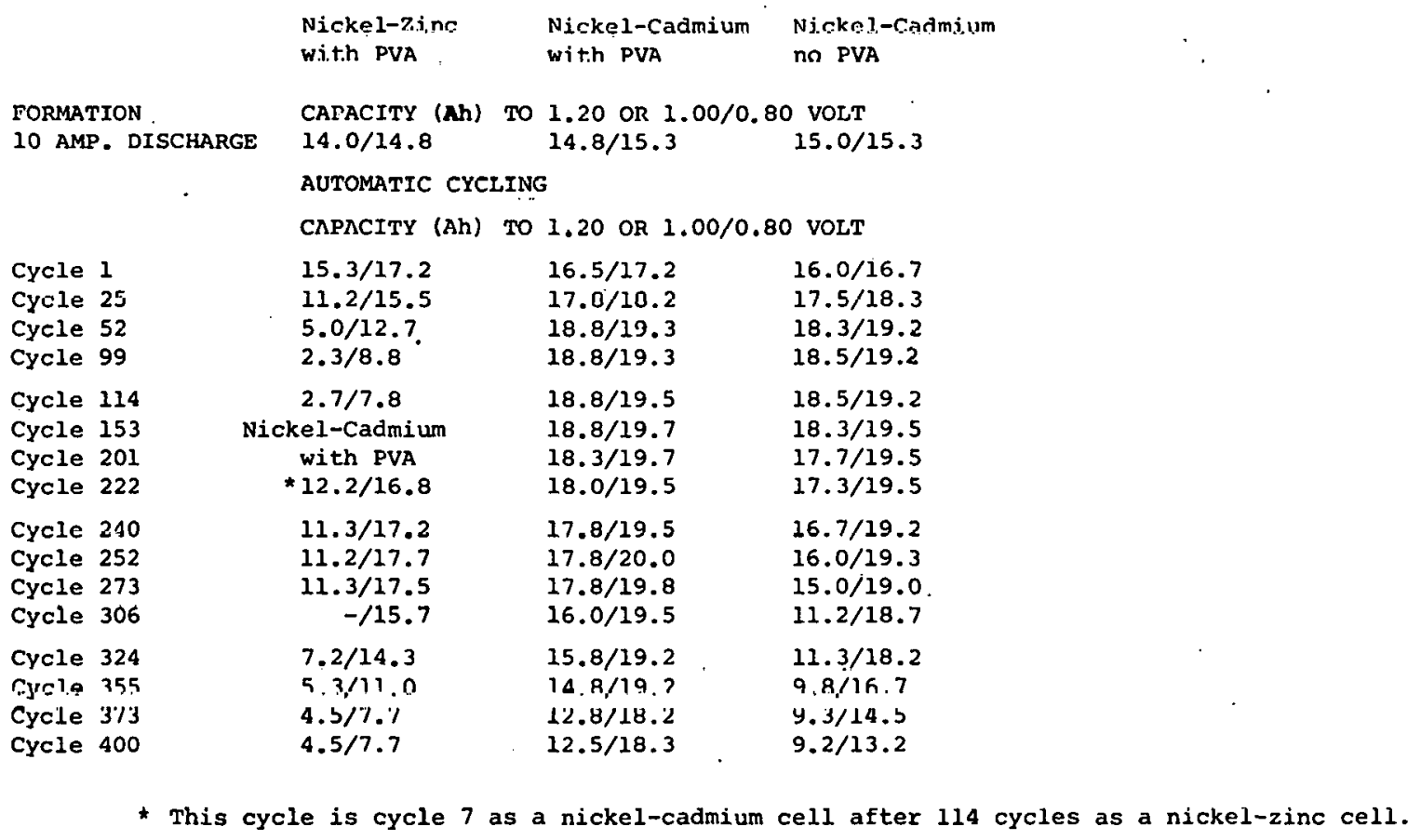


causing an increase in IR between collector and active material. The cycling was discontinued at 114 cycles and the positive plate was washed free of alkali, re-pressed and used to build a new nickel-cadmium cell with PVA. The plate recovered much of its initial capacity although it was not equivalent to the other cells. With cycling, this rebuilt cell showed the effect of its previous history. The cell developed a very high end-of-charge voltage exceeding $2.15 \mathrm{~V}$ and had an initial discharge voltage that exceeded $1.80 \mathrm{~V}$ for several minutes. This indicates. that some zinc left in the positive plate had plated onto the negative plate.

Both nickel-cadmium cells had essentially stable capacities for 250 cycles. This would imply that the mass transport of the electrolyte is not materially affected by the microporous barrier. The subsequent decrease in capacity is believed due to electrode deterioration. No long-term effect of zinc or zinc oxide contamination of the positive was evident.

\subsection{TEFLONIZED GRAPHITE}

In an attempt to eliminate the second discharge plateau and improve capacity, cells were made with pre-Teflonized graphite A diluted dispersion of Téflon 3170 was mixed with Asbury graphite until the Teflon was absorbed and formed agglomerates. These were filtered and dried at $50^{\circ} \mathrm{C}$. Teflon-graphite concentrations of

1 and: $2 \%$ were made into electrodes using commercial Ni hydrate I, and 1\% Teflon binder. For comparison, electrodes were also made with 1, 2 and 3\% Teflon binder with Asbury graphite. These were formed into 250. Ah single plate nickel-zinc cells with PVA microporous barriers. 
The cells were given 50 standard charge-discharge cycles to essentially $60 \%$ of their nominal capacity. At this point, the effect of increased Teflon content was minimal in improving cell capacity and eliminating the second discharge plateau.

Another experiment was conducted using a modification of this pre-Teflonized graphite. In an experiment which was similar to the previous one, a diluted dispersion of Teflon 3170. was mixed with Ionza graphite until the l'eflon particles were abjorbcd, forming agglomerates: These were filtered and dried at $50^{\circ} \mathrm{C}$. The mass was then heated at $300^{\circ} \mathrm{C}$ for 90 minutes so that the final product was in powder form. T'eflon-graphite concentrations of 0 , 0.25 and $0.50 \%$ were made into electrodes using commercial $\mathrm{Ni}$ hydrate $\mathrm{I}$ and 2\% Teflon binder. These electrodes were made into 250 Ah single plate nickel-zinc cells using Celgard k-30.7 microporous barriers. The cells were given a number of deep discharge cyeles after the initial cycling failed to develop full capacities. Inputs of as much as $400 \%$ made only a small improvement in the cell capacities, achieving only $60 \%$ utilization. At the end of 80 cycles, the effect of pre-Teflonization of the graphite to decrease the second plateau was minimal. It appears that the elimination of the second discharge plateau will require a different approach.

\subsection{ERC NICKEL HYDRATE VARIATIONS}

Several different nickel hydrates that showed improved results in nickel-cadmlum cells were made into nickel-zinc cell.s to determine whether there was a difference in the charge efficiency of the positive plate. These included 1.5 and $5 \%$ coprecipitated cobalt-nickel, $5 \%$ cobalt after nickel and $5 \%$ coprecipitated 
cobalt-nickel hydrate made using sodium hydroxide. These hydrąès were made into $250 \mathrm{Ah}$ single plate cells using standard procedures with PVA microporous barriers.

The celis were tested using the standard charge-discharge cycle and all were below $60 \%$ of nominal capacity after 40 cycles. These variations prociuced only nominal changes in the cell behavior. Additional cobalt aids in developing the positive plate capacity and the addition of cobalt after nickel hydroxide is precipitated imparts additional charge efficiency although the cyclic capacity loss is greater than with coprecipitated hydrate. This is similar to results with nickel-cadmium cells. Precipitation with sodium hydroxide does not appear to produce any improvement, but its use could be justified on an economic basis.

In an experiment to improve the utilization of the ERC 1.5\% cobalt-nickel hydrate, several variations were made in its preparation. Previous tests had shown that if cobalt was added after the nickel precipitation, rather than as a coprecipitate, : the positive plate obtained its maximum capacity in a fewer number of cycles. This was offset by the fact that the coprecipitated hydrate had a more stable cyclic capacity. In an experiment to combine both advantages, a portion of the cobalt was coprecipitated and a portion was added later. In addition, a test was made on the effect of adding cadmium after a coprecipitate of cobalt and nickel.

The hydrates were made into electrodes using standard procedures. The 250 Ah rell.s made using Celgard $\mathrm{K}-307$ microporous barriers and 1\% lead oxide $+2 \%$ cadmium oxide as the zinc 


\section{ENERGY RESEARCH CORPORATION}

additive. All of the variations and test data are given in Table I. 13 .

The cycling data show that adding. 1\% cobalt after a coprecipitate of $0.5 \%$ cobalt-nickel will result in a hydrate that achieves an improved capacity with fewer cycles and is more stable during cycling. Additional variations are being tried to densify the nickel hydrate to improve electrode structure and capacity for nickel-zinc cells before incorporating this improvement in our standard procedure.

\subsection{ELECTROLYTE ADDITIVES}

In another approach to improve the capacity of the positive plate, electrolyte additives are being.tried to decrease the interaction of the soluble zinc products and nickel hydrate. In this experiment, unformed cells were filled with standard electrolyte containing 5\% barium hydroxide or 5\% potassium fluoride. Although not all of the barium compound appeared to dissolve, the quantity which did dissolve should react with the zincate ion to form an insoluble species. In the case of potassium fluoride, it was expected that the formation of the relatively insoluble zinc fluoride would occur. For comparison, cells with preformed and unformed plates were tested with standard electrolyte. The data for these cells as well as 136 standard charge-discharge cycles are given in Table I.14.

The formation data show that the addition of barium and fluoride serves to increase the cell capacity between 1.20 and $0.80 \mathrm{~V}$. During automatic cycling to $1.20 \mathrm{~V}$, these additions had an adverse effect upon the development of cell capacity. 
Table $\mathrm{I} .13$

ERC 1:5\% COBALT-NICKEI VARIATIONS

250 A SINGLE PLATE NI-ZN CELLS

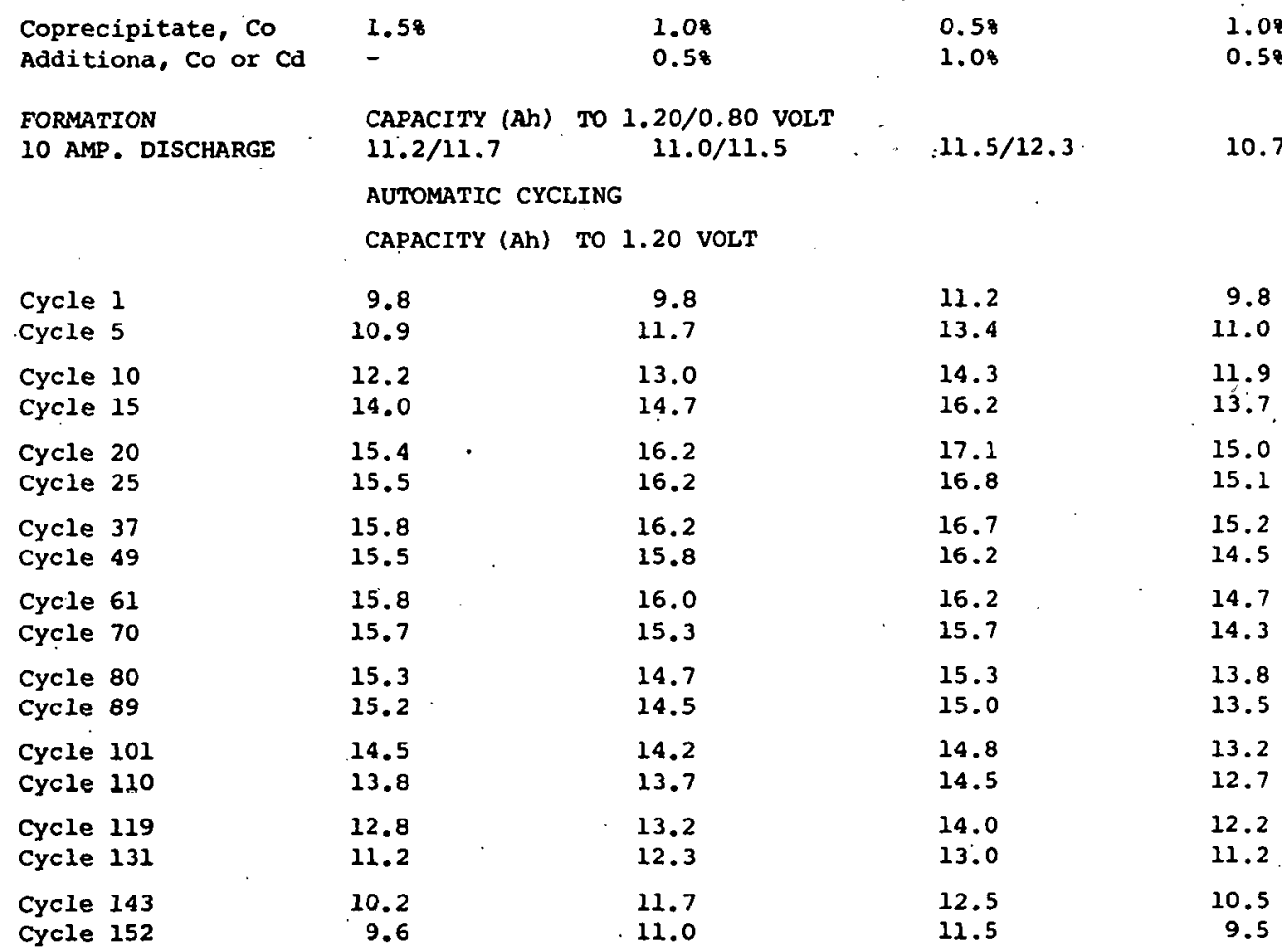

Table I.14

ELECTROLYTE ADDITIVES

COMMERCIAL NI HYDRATE I

250 Ah SINGLE PLATE NI-ZN CELLS

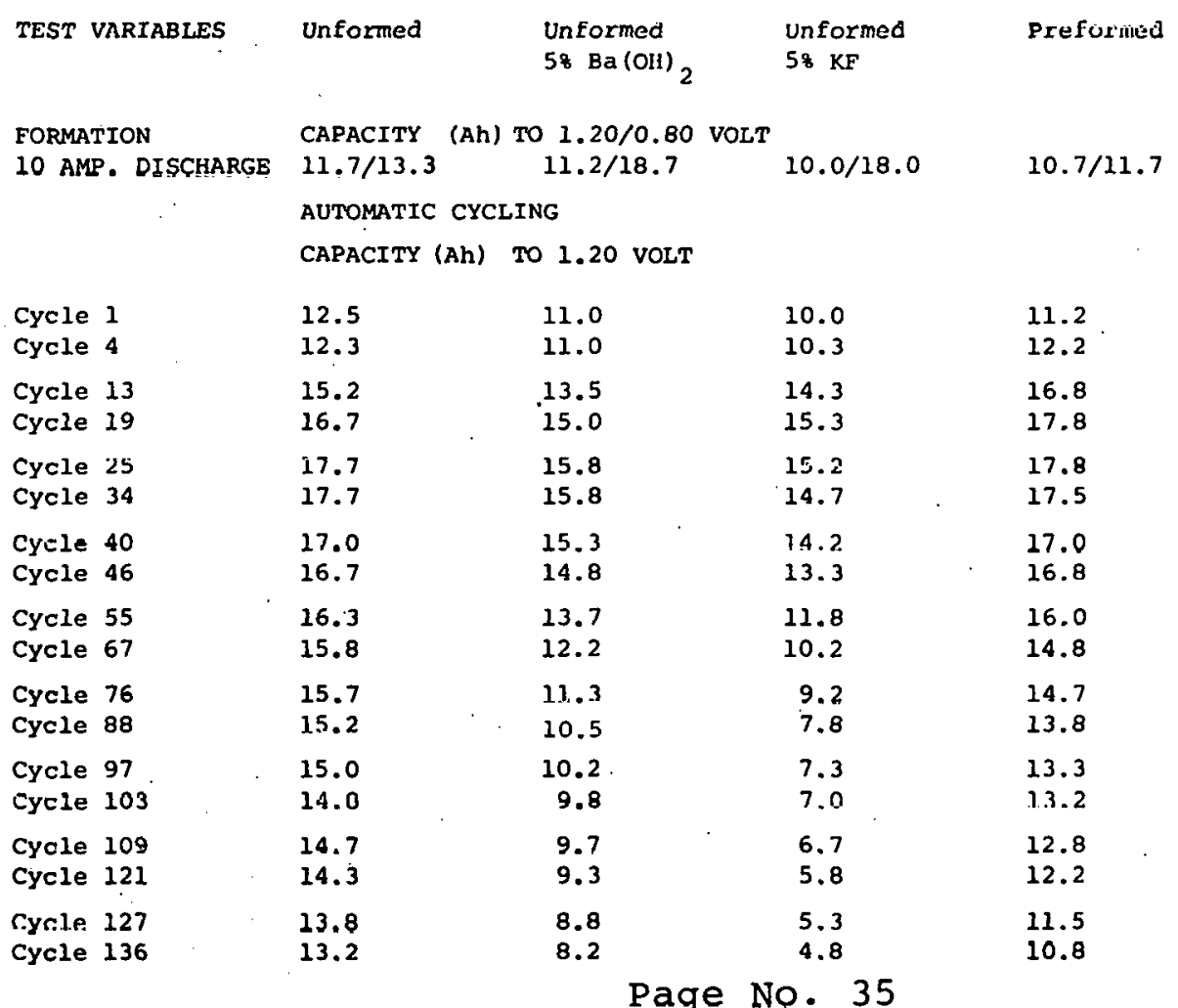


The preformed plate showed only a slight advantage over the unformed plate in developing its maximum capacity. The unformed plate however had better cyclic capacity majntenance. other compounds having an affinity for the zincate ion will be tried to determine their effect upon improving positive plate capacity with cycling. 


\section{ENERGY RESEARCH CORPORATION}

\section{0 CONCLUSIONS}

Cells with $1.5 \%$ cobalt-nickel hydrate prepared by the WD procedure gave stable cyclic capacity for over 500 cycles.

The use of treated Asbury graphite improved the discharge voltage and cell capacity of nickel-cadmium cells. Substitution of Lonza graphite for Asbury graphite produced cells that are almost equivalent to those with treated Asbury graphite.

The benefit of adding a portion of the conducting graphite during precipitation was not resolved. This technique used by some manufacturers of pocket plate nickel hydrate will require further investigation.

The sequential addition of cobalt after nickel, rather than as a coprecipitate, inproves the initial charge acceptance of the nickel hydrate. However, coprecipitated cobalt-nickel hydrate has better cyclic capacity stability.

Preparation of the hydrate with sodium hydroxide does not appear to improve its cyclic capacity stability, but its use could be economically justified.

The use of a microporous membrane barrier to prevent cadmium soft shorts is not required for 20 Ah nickel-cadmium cells up to 300 cycles although some cells have given 700 cycles prior to any indication of soft shorts. Commercial Ni hydrate I, classified into two different particle sizes, did not show any significant effect due to particle size.

Commercial nickel hydrate I, made into plates that were preformed prior to final assembly in 20 Ah nickel-cadmium cells 
did not cycle satisfactorily.

Commercial nickel hydrate I received during May 1980 produces cells having cyclic capacity stability equivalent to some previous tests. Reduction in the cobalt content from 15 . to $0.6 \%$, leads to a small loss of cyclic capacity stability.

Commercial nickel hydrate II, made from nickel chloride gave marginally acceptable performance. Nickel hydrate made from their nickel chloride at ERC was incorporated in a cell which gave over 200 cycles before falling below $20 \mathrm{Ah}$.

Experiments with commercial trivalent nickel hyarate III produced cells with acceptable performance and will require additional investigation.

A cell with commercial cobalt-nickel hydrate IV using the ERC procedure has satisfactory cyclic capacity stability

Nickel-zinc cells develop a second plateau in the discharge curve with cycling that leads to a decrease in cell capacity. Nirkel-cadmium cells made with the same microporous barrier do not show this phenomena. Zinc compounds deposited in the positive plate were shown to be responsible for this behavior.

The pre-Teflonization of graphite to improve electrode integrity and decrease possible delamination had little effect on decreasing the formation of the second plateau.

Variation in the preparation of $1.5 \%$ sobalt-nickel hydrate to add a portion of the cobalt as a coprecipitate and sequentially leads to a small improvement in the charge acceptance of the positive active material.

Additions to the electrolyte to decrease the influence of soluble zinc species on the nickel hydrate will require a systematic evaluation of known insoluble zinc compounds. 


\subsection{FUTURE WORK}

The testing of nickel hydrates in nickel-cadmium cells will be performed primarily to verify results obtained in nickelzinc cells. The aim will be to improve the utilization of the nickel electrode (Ah/g) through improved charge acceptance and utilization.

Variations will be made in the hydrate preparation procedure to modify hydrate morphology. This will lead to an improved electrode structure to obtain optimum utilization of the active material in nickel-zinc cells.

Electrolyte additions to decrease the influence of soluble zinc species on the nickel electrode will be investigated further. 
SECTION III

ZINC ELECTRODE DEVELOPMENT

FOR NI-ZN CELLS - TASK II

Page No. 40 


\subsection{INTRODUCTION}

The performance related problems of the $\mathrm{Ni}-\mathrm{Zn}$ cell (such as gas evolution during charge, decline in capacity with cycling, abrupt failure, inability to operate in the sealed condition and drying out of the electrode plates) are directly traceable to the zinc electrode. ${ }^{1}$ Some of these problems are attributed to shape change, dendritic deposition and passivation at. the zinc electrode. ${ }^{2}$ Therefore, the objective of this task is to find cost-effective solutions to these problems and develop a zinc electrode which is capable of 300 cycles in a large Ni-zn battery.

The experimental work is divided into electrode technology and basic electrochemical study of the reversible $\mathrm{zn}$ electrode. The technical approach to electrode technology is based on polymer bonded zno containing a suitable combination of substrate and additives. $^{3}$ As substrate, a thin copper foil (thickness $=0.002$ in.) has been selected based on previous results.

The objective of the basic study is to rationalize shape change and passivation. A steady state polarization study, has been initiated in order to elucidate the kinetics of zinc dissolution and deposition, particularly the sequence of partial reactions, dependence of reaction rate on temperature, $\mathrm{OH}^{-}$and zincate concentrations and repetitive cycling. An electrochemical cell consisting of a segmented zinc electrode, nickel-oxy hydroxide counter electrode and $\mathrm{Hg} / \mathrm{HgO}$ reference electrode is used for this study. 


\section{ENERGY RESEARCH CORPORATION}

\subsection{TECHNICAL DISCUSSION}

\section{I BASIC ELECTROCHEMICAL STUDY}

The kinetics of $\mathrm{Zn}$ dissolution and deposition is being investigated using a galvanostatic polarization procedure. Although the study examines the sequence of partial reactions, reaction order terms, and rate-determining steps, the primary objective is to explain the changes in the polariztion characteristics of zinc with cycling and relate these changes to shape change and passivation.

\subsubsection{Experimental}

The polarization and cycling experiments were performed with a specially designed cell consisting of one positive and one negative electrode and arranged in a Plexiglas housing. A separator system consisting of a layer of pellon and three layers of PVA was used as electrical insulation between the electrodes. The positive electrode (the counter electrode during polarization) is the standard ERC roll-bonded NiOOH pasted to a nickel exmet collector. The negative electrode (working electrode during polarization) is the usual ERC roll bonded Zno electrode with some variations. Silver foil with nine spot-welded tabs distributed over the surface of the electrode is used as the substrate for the $\mathrm{zn}$ electrode. These tabs are used to monitor overvoltages during polarization of different $\mathrm{Zn}$ electrode areas. 


\section{ENERGY RESEARCH CORPORATION}

For normal cell cycling (charge and discharge) the three strands of silver wire which are welded to the substrate at one corner are used. The roll bonded $\mathrm{Zno}$ is pasted to the side opposite the voltage monitoring tabs. The region opposite each voltage monitoring tab forms a particular section at the electrode. Thus there are nine distinct sections at the $\mathrm{zn}$ electrode for comparison of polarization characteristics. The entire assembly is oriented in the horizontal position during all experiments. The top side of the Plexiglas case has orifices which coincide with the tab locations. A Hg/Hgo reference electrode is inserted through the orifices for potential measurement. The cell is filled with $\mathrm{KOH}$ of appropriate concentration. Figure II.l illustrates the cell.

A PAR potentiostat/galvanostat, Model 371 , is used as a galvanostat to polarize the working electrode. For cycling purposes an automatic cycler with a six-hour charge and two-hour discharge regime is used.

\section{1 .2 Dependence of Kinetics on $\mathrm{OH}^{-}$Concentraton}

A zinc electrode prepared from $98 \%$ ' $\mathrm{HnU}$ and $2 \%$ 'L'E' was used for this study. The variations of potential with current under steady state conditions during reduction and oxidation of this electrode was studied in four different concentrations of $\mathrm{KOH}$. The procedure consisted of first determining the open circuit voltage (OCV) as a function of $\mathrm{pH}$. Then the electrode was polarized to a certain overvoltage in both cathodic and anodic directions. The variations of OCV with KOH concentration are given in Figure I.I.2. Note that the data correspond to a fresh electrode before any cycling, 
CROSS SECTIONAL VIEW

TOP VIEW

CELL SKETCH

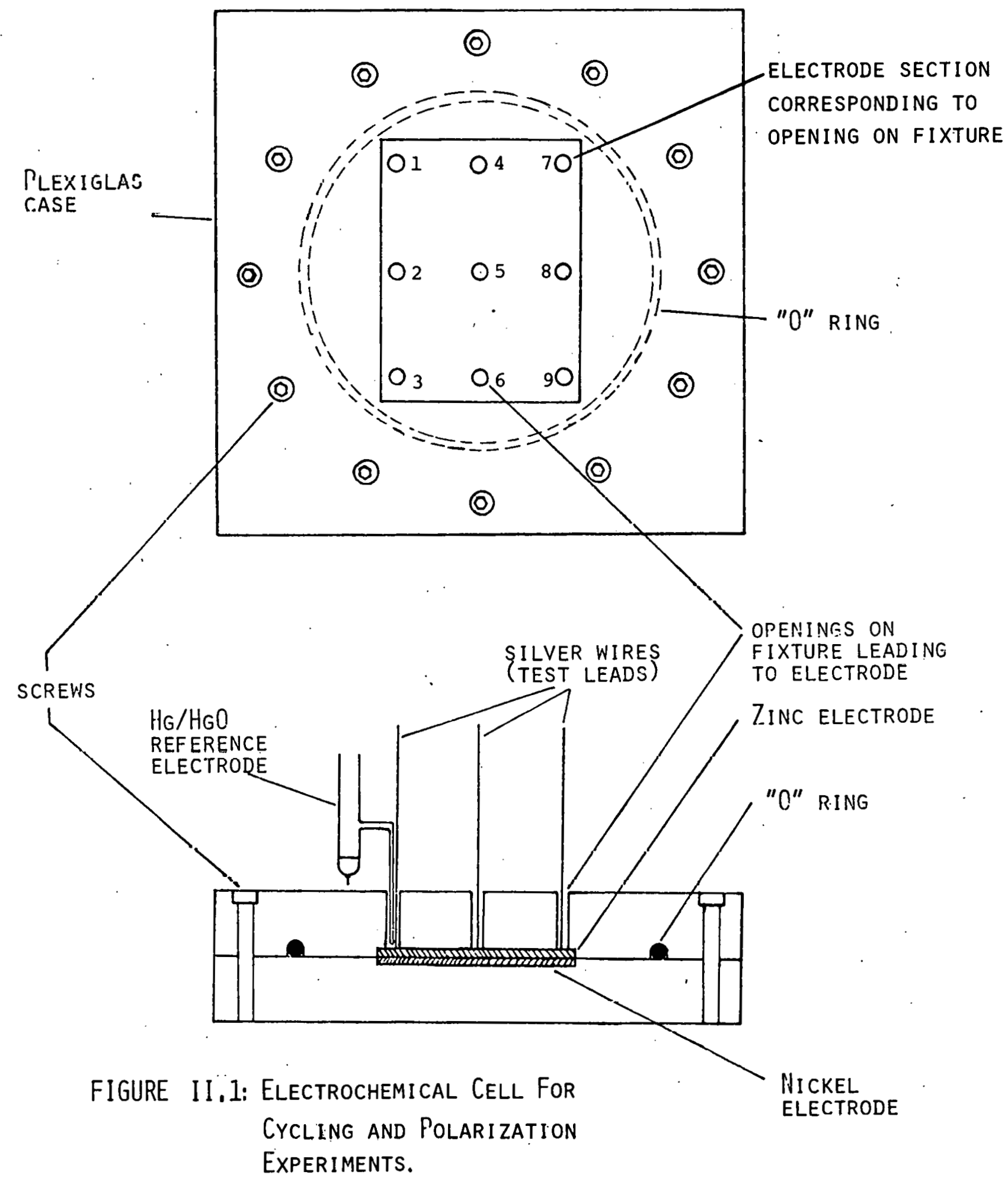




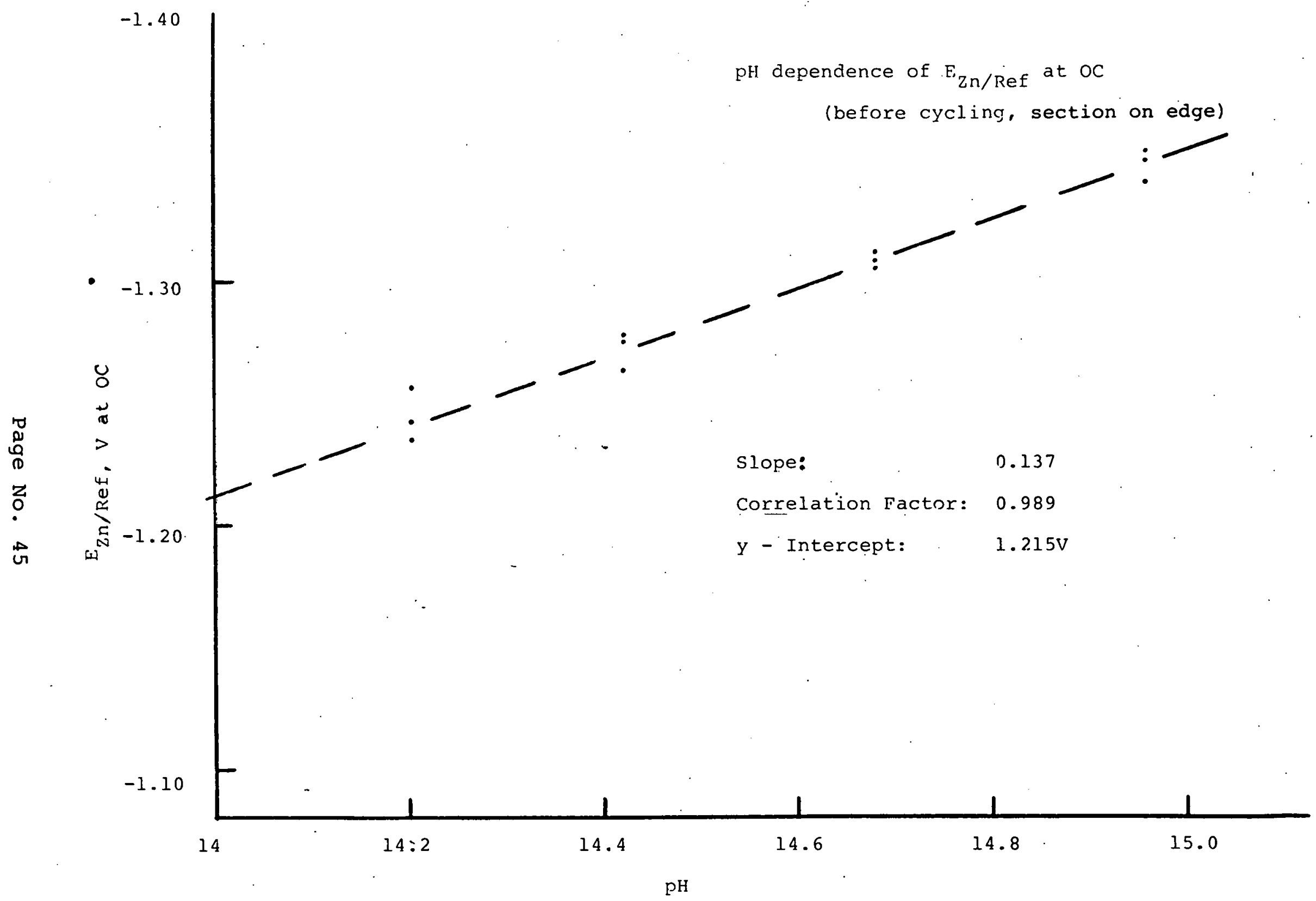

FIGIRE II.2: THE DEPENDENCE OF ZINC POTENTIAL ON $\mathrm{OH}^{-}$CONCENTTRATION AT OPEN CIRCUIT 


\section{ENERGY RESEARCH CORPORATION}

and the entire relationship is for one of the nine sections of the electrode (the one closest to the edge). The data for the other sect n studied (the one at the center) was in agreement with the edge section.

The relationship between $E_{o c v}$ and $\mathrm{pH}$ was linear with a slope of 0.137 . The intercept is $-i .215 \mathrm{~V}$. This behavior has been reported previously. It is believed that the potential is Nernstian. 5

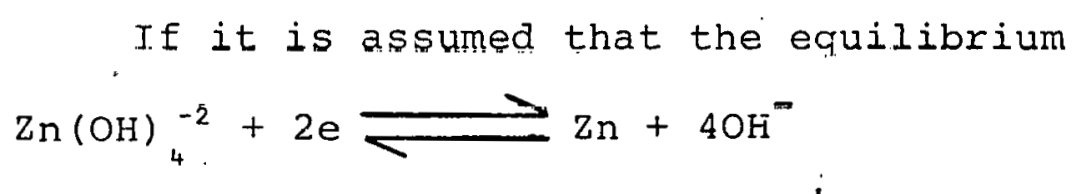

exists at open circuit, the expression for the equilibrium constant is

$$
\mathrm{K}=\frac{[\mathrm{OH}]^{4}}{\left[\mathrm{Zn}(\mathrm{OH})_{4}^{-2}\right]}
$$

substituting molarity for activity and neglecting liquid junction, the Nernst equation can be written as

$$
E=E^{O}+\frac{2.303 R T}{2 F} \log \frac{[\mathrm{OH}]^{-4}}{\left[{\mathrm{Zn}(\mathrm{OH})_{4}^{-2}}_{4}\right]}
$$

The expression predicts a slope of II: mV for the plul ur pulential versus $\mathrm{OH}^{-}$concertration. The experimental value of $137 \mathrm{mV}$ compares well with that predicted by the equation.

Figure II.3 shows the relationship between $\log i$ versus $\mathrm{pH}$ at an overvoltage of $15 \mathrm{mV}$ from E The experimental points in the curve correspond to both electrode sections studied. The relationship is linear with a slope of 0.76 . The result indicates that the rate of deposition 


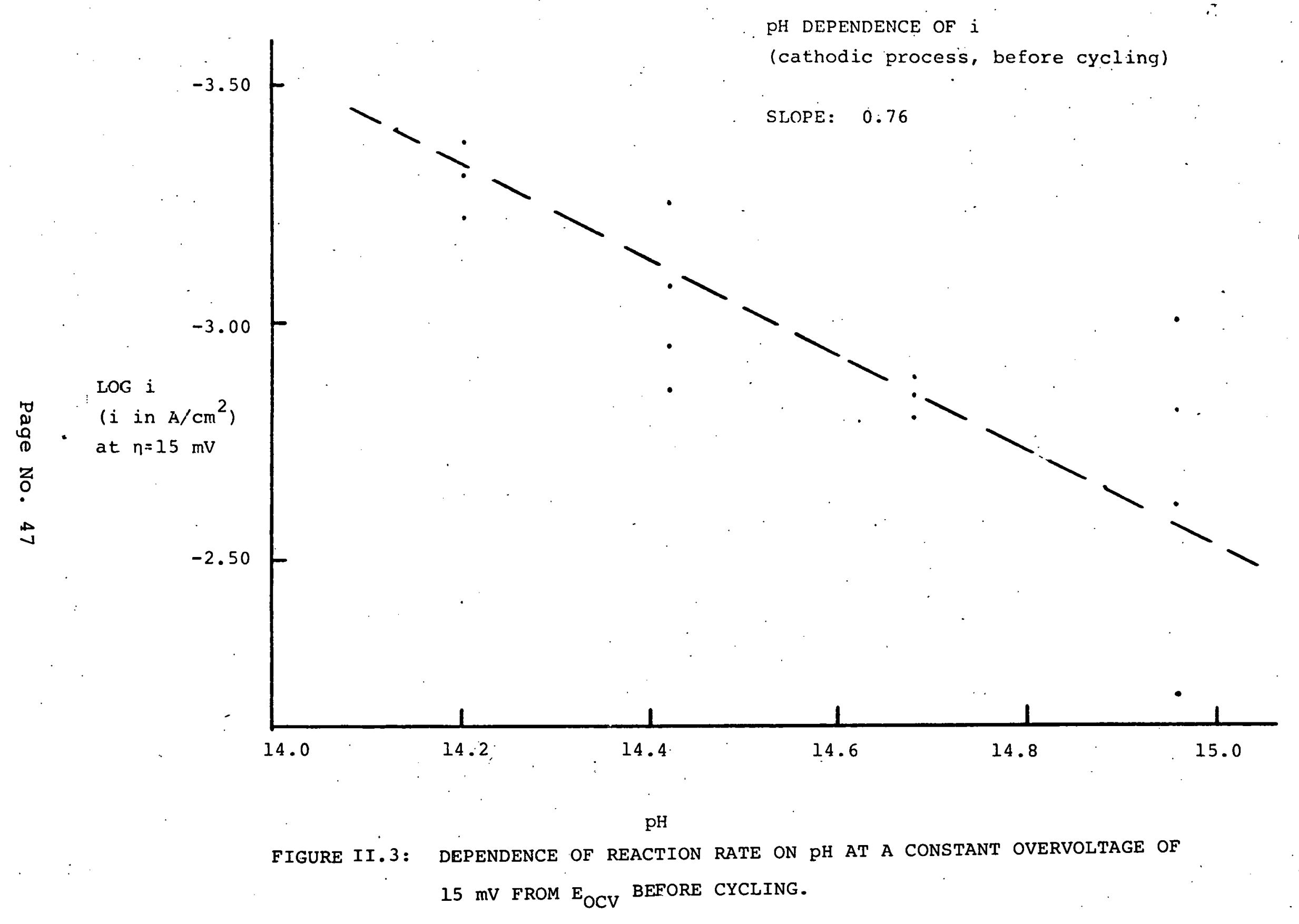


increases with an increase in $\mathrm{pH}\left(\right.$ i.e., $\left.\log (\mathrm{OH})^{-}+{ }^{\prime} 14\right)$. This is an unexpected result since the reduction of zincate yields $\mathrm{OH}^{-}$ as a product. 6

The effect of cycling on the $\log i$ vs pH relationship was also determined. The $\mathrm{Zn}$ electrode was cycled as in a normal operating battery against a $\mathrm{Ni}(\mathrm{OH})_{2}$ electrode. After several cycles (11-14) the $\mathrm{pH}$ dependency was determined. Figure II.4 shows the $\mathrm{pH}$ dependency obtained after cycling. Here again, the rate of deposition increases with $\mathrm{pH}$ but the rate of increase is diminished, as is evident from the slope of the curve. This observation suggests that as the electrode is cycled, the reaction mechanism changes. The electrode was cycled further and the $\mathrm{pH}$ dependency wa's determined. The experimental results showed a great scatter with poor reproducibility. However, the overall effect of cycling was a tendency toward lower dependence of the reaction rate on $\mathrm{pH}$. The dependence of the kinetics on the $\mathrm{OH}^{-}$concentration during anodic polarization was also determined. Figure II.5 shows the $\mathrm{pH}$ dependency for the dissolution reaction for a fresh electrode before cycling. The relationship is linear with a slope of 0.76 . The electrode was cycled as in a battery and the $\mathrm{pH}$ dependency was determined again. The value for $\dot{d}(\log i) / \partial \mathrm{pH}$ decreased after 14 cycles. Figure II.6 shows the effect of cycling on the reaction order with respect to $\mathrm{OH}^{-}$concentration. With further cycling, the value for $\partial(\log i) / \partial \mathrm{pH}$ decreases and it becomes an almost insignificant value.

The anomolous dependency of the cathodic reaction on $\mathrm{OH}^{-}$concentration; may be explained by ässuming a change in the sequence of partial reactions with cycling. In the beginning, the following sequ..lce 


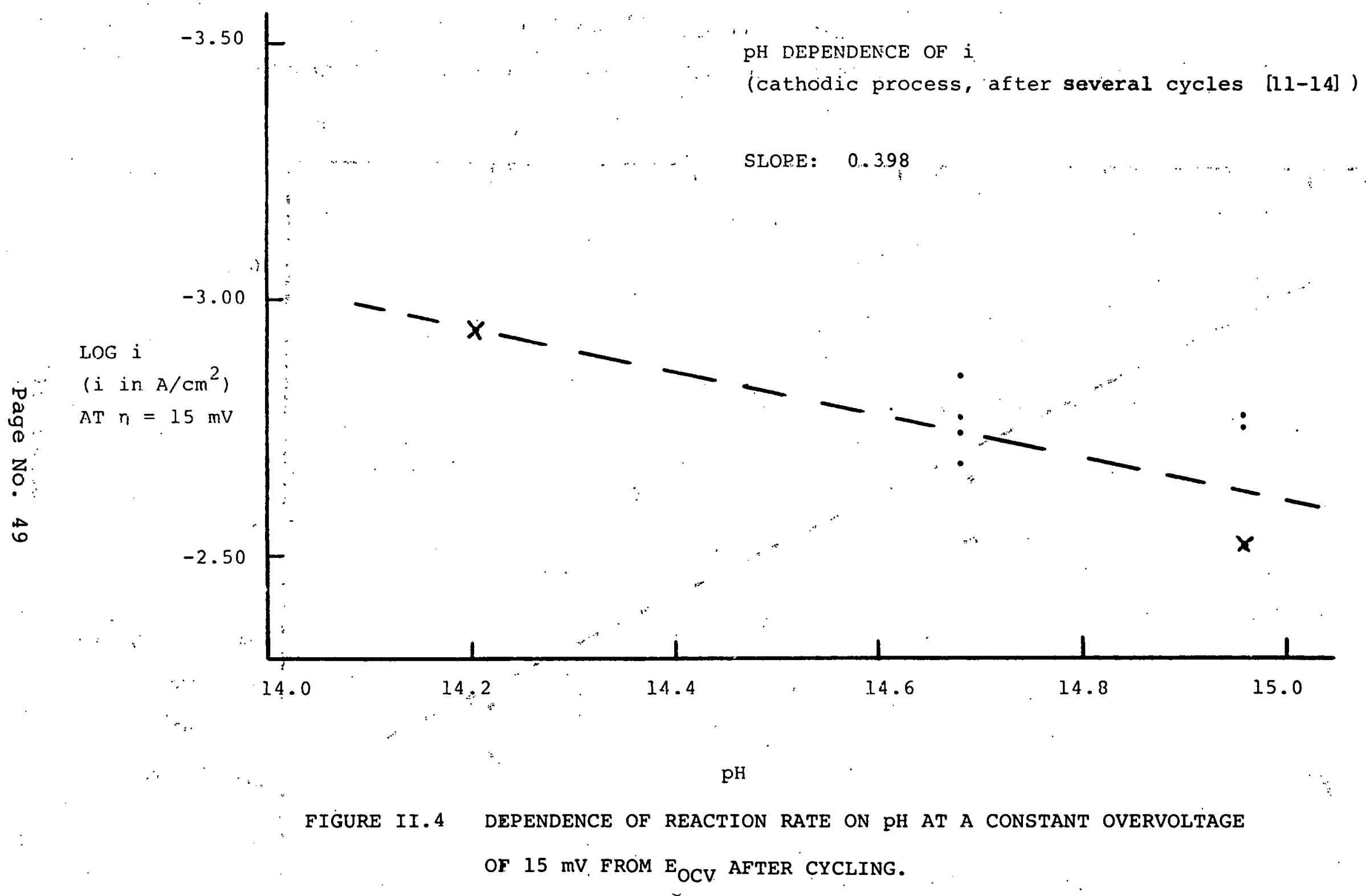




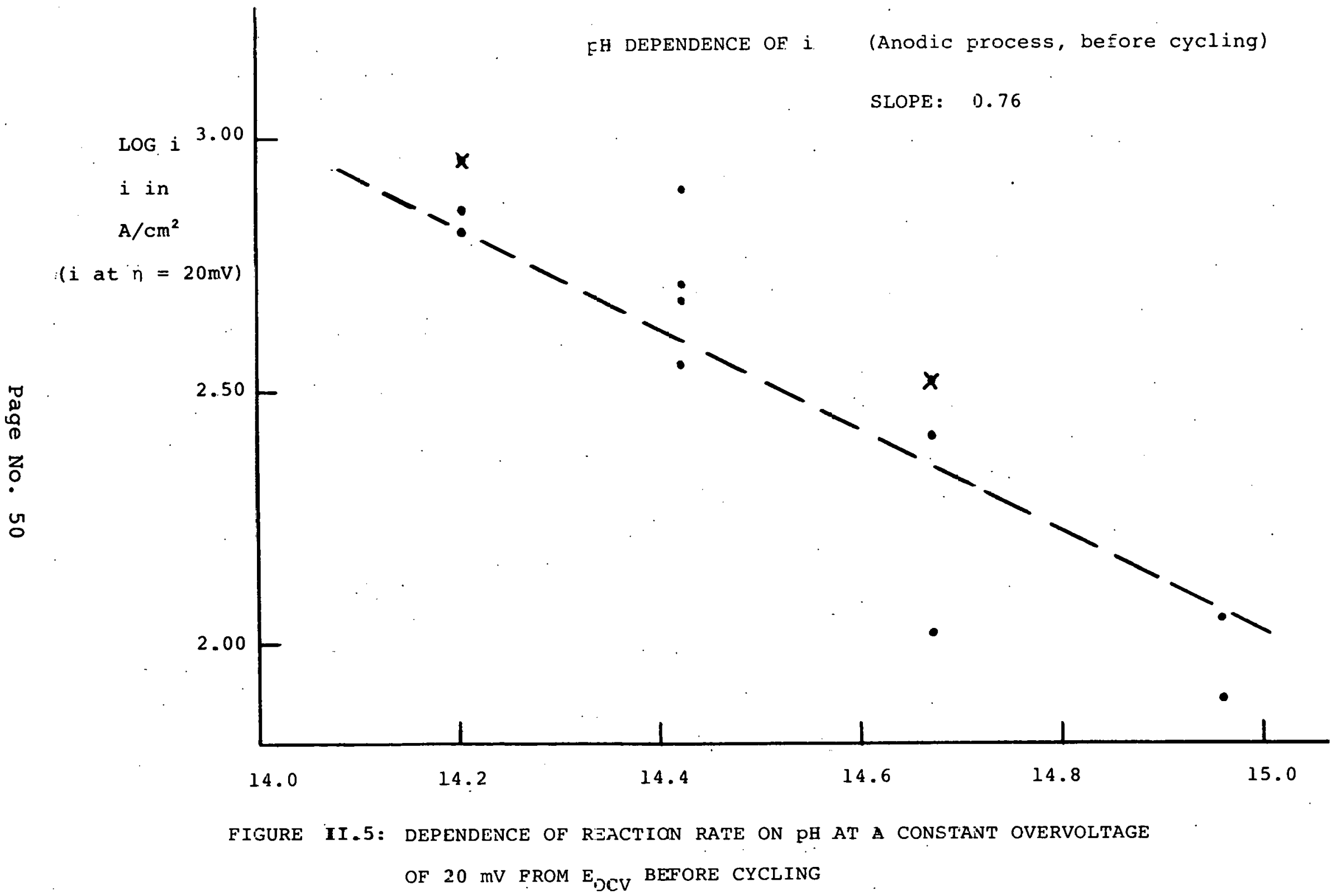




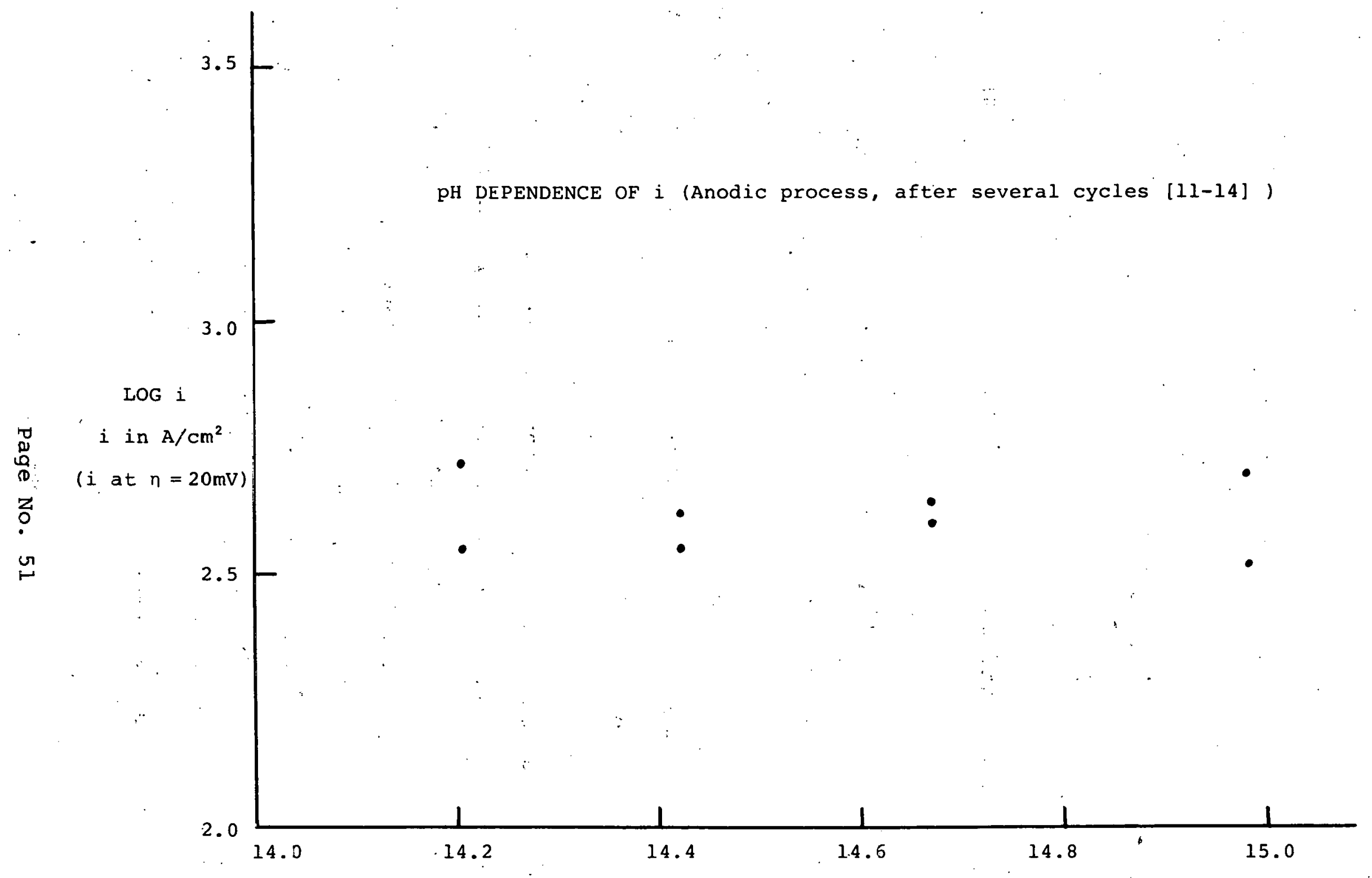

FIGURE II.6: DEPENLENCE OF REACTION RATE ON PH AT A CONSTANT OVERVOLTAGE OF $20 \mathrm{mV}$ FROM E OCV AFTER CYCLING. 
of partial reactions occur.

$$
\begin{aligned}
& \mathrm{ZnO}+\mathrm{H}_{2} \mathrm{O}+2 \mathrm{OH}^{-} \rightleftharpoons \mathrm{Zn}(\mathrm{OH})_{4}^{-2} \\
& \mathrm{Zn}(\mathrm{OH})_{4}^{-2} \rightleftharpoons \mathrm{Zn}(\mathrm{OH})_{3}^{-}+\mathrm{OH}^{-} \\
& \mathrm{Zn}(\mathrm{OH})_{3}^{-}+\mathrm{e} \rightleftharpoons \mathrm{Zn}(\mathrm{OH})_{3}^{-2} \\
& \mathrm{Zn}(\mathrm{OH})_{3}^{-2}+\mathrm{e} \stackrel{\mathrm{RDS}}{\longrightarrow} \mathrm{Zn}(\mathrm{OH})_{2}^{-2}+\mathrm{OH}^{-} \\
& \mathrm{Zn}(\mathrm{OH})_{2}^{-2} \rightleftharpoons \mathrm{Zn}(\mathrm{OH})^{-}+\mathrm{OH}^{-} \\
& \mathrm{Zn}(\mathrm{OH})^{-}=\mathrm{Zn}+\mathrm{OH}^{-}
\end{aligned}
$$

Equation 7 is assumed to be the rate determining step. (RDS). Equations 3 and 9 are included only to indicate the probable path through which metallic $\mathrm{zn}$ is produced. A kinetic expression for the rate of reduction can be formulated based on this RDS, which would explain the initial dependence of the rate on $\mathrm{OH}^{-}$concentration.

Thie sequence of partial leattions, including the RDS, changes with cycling. The importance of conversion of $\mathrm{znO}$ to $\mathrm{Zn}(\mathrm{OH})_{4}^{-2}$ as a condition for reduction diminishes. In addition, the dominant active species on the electrode is no longer the zno which was inltially present. Inotcad a "compact znn" variously described as Type II film dominates the surface (which is believed to be produced during anodic polarization). 7,8 The "compact zno" differs structurally from the normal zno with lower solubility in $\mathrm{KOH}$. On cathodic polarization the species is reduced to $\mathrm{zn}$ as symbolized in the following equation:

$$
\mathrm{ZnO}+\mathrm{H}_{2} \mathrm{O}+2 \mathrm{e} \longrightarrow \mathrm{Zn}+2 \mathrm{OH}^{-}
$$




\section{ENERGY RESEARCH CORPORATION}

Thus zincate formation is less important in the kinetics of a cycled electrode. The reduction reaction may be composed of a new set of partial reactions.

The changes observed on the reaction order term with cycling during anodic polarization may also be explained by assuming $a$ change in the mechanism of reaction. At the beginning the reaction goes through a zincate path to form $\mathrm{zno}$. The. reaction can be formulated as follows:

$$
\mathrm{Zn}+4 \mathrm{OH} \longrightarrow \mathrm{Zn}(\mathrm{OH})_{4}^{-2}+2 \mathrm{e}
$$

The zincate so produced generates zno by a decompositionprecipitation reaction

$$
\mathrm{Zn}(\mathrm{OH})_{4}^{-2} \longrightarrow \mathrm{ZnO}+2 \mathrm{OH}^{-}+\mathrm{H}_{2} \mathrm{O}
$$

which is independent of the anodic polarization reaction. Upon cycling, the reaction rate depends less on the $\mathrm{OH}^{-}$ concentration. The mechanism changes to:

$$
\mathrm{Zn}+2 \mathrm{OH}^{-} \longrightarrow \mathrm{ZnO}+\mathrm{H}_{2} \mathrm{O}+2 \mathrm{e}
$$

Where $\mathrm{ZnO}$ is the "compact $\mathrm{ZnO}$ " described in Reference 7. Equation 13 predicts a lower dependency on $\mathrm{OH}^{-}$concentration. Experiments are in progress to substantiate the observations about reaction mechanisms during cathodic and anodic processes.

\subsubsection{Electrode Polarization, Tafel Slope and Exchange Current} To obtain diagnostic criteria on the reaction mechanism, parameters such as steady-state, open circuit potential, Tafel slope and exchange current were determined for the following types of zinc electrodes and electrolyte concentrations: 


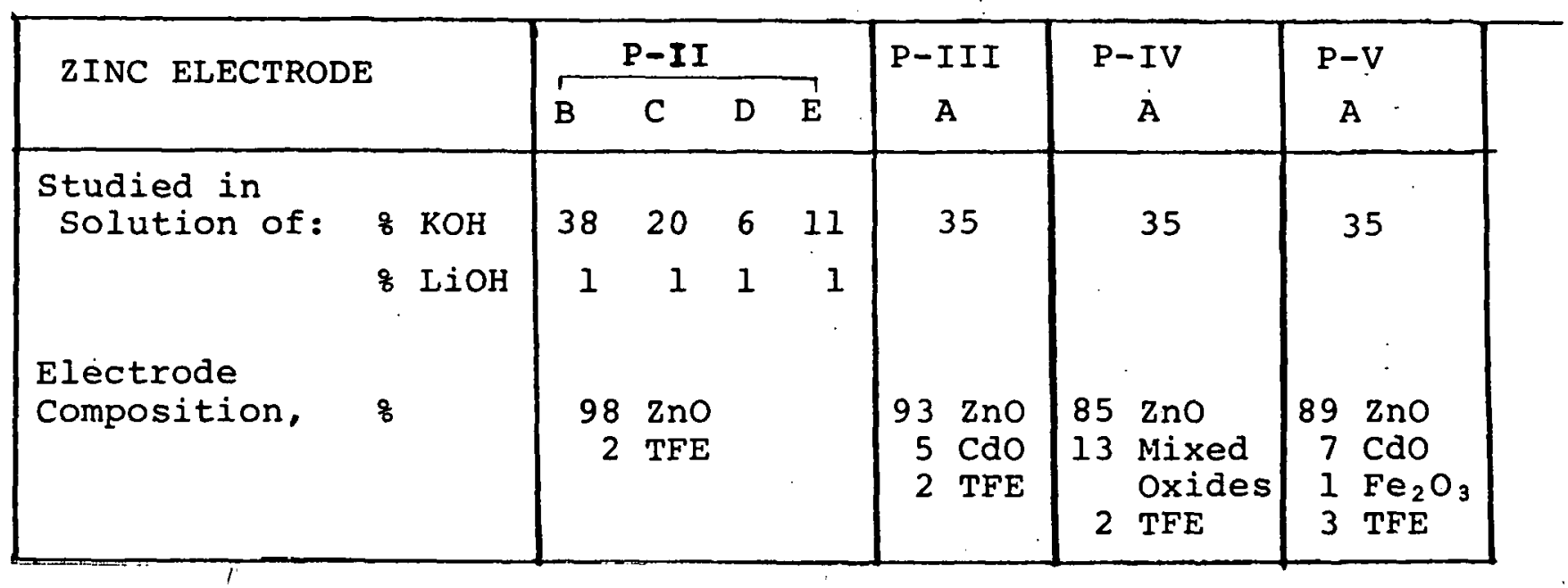

As mentioned earlier, the location of the electrode area (or section) studied was one of the variables in the experiments. The experimental results are given in Appendix A. The scatter in the experimental results for Tafel slope, polarization at a particular current-density, etc., is normal, considering the nature of the experiment and interaction of parameters. Despite this, the data show a definite trend which can be used advantageously in providing some theoretical explanations. lhe Appendix contains information for important sections of the electrode, i.e., Section 3 which corresponds to the edge and section 5 which corresponds to the center.

The OCV showed a shift to the anodic direction when the value for the edge section was compared to that of the center section. The magnitude of this shift 13 a function of the electrode type and it increases in this order: P-IIB > P-IIIA > P-IVA > P-VA (i.e., the potential distribution was more uniform for $\mathrm{P}-\mathrm{VA}$ which contains $\mathrm{CdO}+\mathrm{Fe}_{2} \mathrm{O}_{3}$ as additives, and P-IVA, which contains a mixed oxide type additive). Upon Cycling, the magnitude of the shift which is not linear with the ordinal number of cycles increases. Again, the magnitude of the 


\section{ENERGY RESEARCH CORPORATION}

shift with cycling is greater for P-IIB than for P-IVA.

The overvoltage of the $\mathrm{zn}$ during cathodic and anodic polarization at a current density of 4 and $12 \mathrm{~mA} / \mathrm{cm}^{2}$, :

respectively, was studied as a function of the same variables. A cathodic current density of $4 \mathrm{~mA} / \mathrm{cm}^{2}$ corresponds to the normal charging current density in an operating battery and the anodic current density of $12 \mathrm{~mA} / \mathrm{cm}^{2}$ corresponds to the normal discharge current density. Again, the overvoltage for the edge section was found to be greater than that for the center section in all instances, i.e., the edge sections are more polarized than the center sections. Further comparison of the electrode types shows the ability to polarize increases in the order; $\mathrm{P}-$ IIB $>\mathrm{P}-$ IIIA $>\mathrm{P}$-IVA.

The exchange current density, $i_{0}$, which is a direct measure of the reversibility of the reaction (important in rechargeabie batteries) was examined as a function of electrode type and cycling. The $i_{0}$ was generally greater for P-IVA than for P-IIB. The io decreased for P-IIIA with cycling which was not the case for P-IVA and P-VA.

The Tafel slope generally falls in the range of 30 to. 60 mV/decade of current. There are exceptions "which may be attributed to shorting, interference from trapped $\mathrm{H}_{2}$ and $\mathrm{O}_{2}$, or passivalion. When an cxpcriment was thringht. to be free of any of the above problems, the Tafel slope was 35 to $45 \mathrm{mV} /$ decade. Due to the scatter in the experimental data, it is difficult to form conclusions about the dependence of Tafel slope on cycling. 
2.1.4 Physical Significance of the Polarization Results

The trends shown by the data on open circuit potential

and overvoltage (polarization) may be related to the deactivation of the electrode by shape change. As stated in section 2.1.2. the OCV may be considered Nernstian and it provides a direct indication of $\mathrm{OH}^{-}$concentration. Since the OCV shows an anodic shift when comparing the OCV of the center to the OCV of the edges, it may be concluded that the concentration of $\mathrm{OH}^{-}$is higher at the edges than at the center. Thus a pH gradient is estahlished on the $\mathrm{Zn}$ electrode. The higher concentration of $\mathrm{OH}^{-}$contributes to increased dissolution of $\mathrm{zno}$ at the edges. Since the anodic shift increases with cycling, greater difference in $\mathrm{OH}^{-}$concentration exist and a greater amount of $\mathrm{Zno}$ can be dissolved from the edges with progressive cycling.

The overvoltage during polarization is higher at the edges than at the center. The magnitude of the difference is such that during cathodic polarization, $\mathrm{H}_{2}$ evolution begins earlier at the edges. This is equivalent to saying that the amount of $\mathrm{z}$ deposited is less at the edges than at the center. The overvoltage (or degree of polarization) increases with an increase in cycle number i.e., with progressive cycling, less and less $\mathrm{zn}$ is deposited at the edges. Now, during the anodic process, the $\mathrm{Zn}$ dissolution occurs with greater efficiency at the center than at the edges, as indicated by the anodic overvoltage data. Thus more $\mathrm{Zn}$ and $\mathrm{zno}$ are produced at the center, leading to so-called shape change.

The migration of dissolved zincate from the edges to the center occurs during the cathodic process (charging) since the predominant reaction at the center is reduction of zincate with no competition from the $\mathrm{H}_{2}$ evolution reaction. On the contrary, Page No. 56 


\section{ENERGY RESEARCH CORPORATION}

the edges support the $\mathrm{H}_{2}$ evolution reaction right from the beginning of charge.

According to our theory, the lower the anodic shift of $\mathrm{OCV}$ and overvoltage during polarization, the lower the shape change. The experimental data obtained from electrode P-IVA, which exhibited minimum shape change after 80 cycles, showed a very low anodic shift and ability to polarize. As further proof, a zinc electrode composition identical to P-IVA displayed a cycle life of 260 in a 20 Ah tri-electrode cell.

\subsection{CONCLUSIONS}

A new theory, for shape change, based on $\mathrm{pH}$ gradient and ability of the electrode to polarize is proposed which can explain some of the correlations between battery operating parameters and shape change. 


\section{REFERENCES}

1. Klein, M. et al, Proceedings 14 th Intersociety Energy Conversion Engineering Conference, Boston, 1979, pg. 646 .

2. MCBreen, J. and Cairns E.J. Advances in Electrochemistry and Electrochemical Engineering, Vol. II, Gerischer, H. and Tobias, C.W. Eds., Wiley, 1978.

3. Baker, B.S., Klein, M., U.S. Patent 3,898,099.

4. McEreen, J., U.S. Patent 3,876,470

5. Gibbard, H.F. et al., Extended Abstracts, No. 118, The Electrochemical Society, Fall 1979 Meeting, Los Anyeles, October, 1979.

6. Bockris, J.O'M.', et al. J. Electrochem. Soc., 119, 285, 1972.

7. Liu, Ming-Biann, Cook, G.M., and Yao, N.P., Report No. ANL/OEPM80-1, prepared for DOE under Contract W-31-109-Eng-38; May 1980.

8. Powers, R.W., and Breiter, M.W., J. Electrochem. Soc., 116, $719,1969$. 
ENERGY RESEARCH CORPORATION

APPENDIX A

Page No. 59 
TABLE A.I

ELECTRODE P-IIB

(in $35 \% \mathrm{KOH}$ with $18 \mathrm{LiOH}$ )

COMPOSITION: $988 \mathrm{ZnO}, 2 \% \mathrm{TFE}$

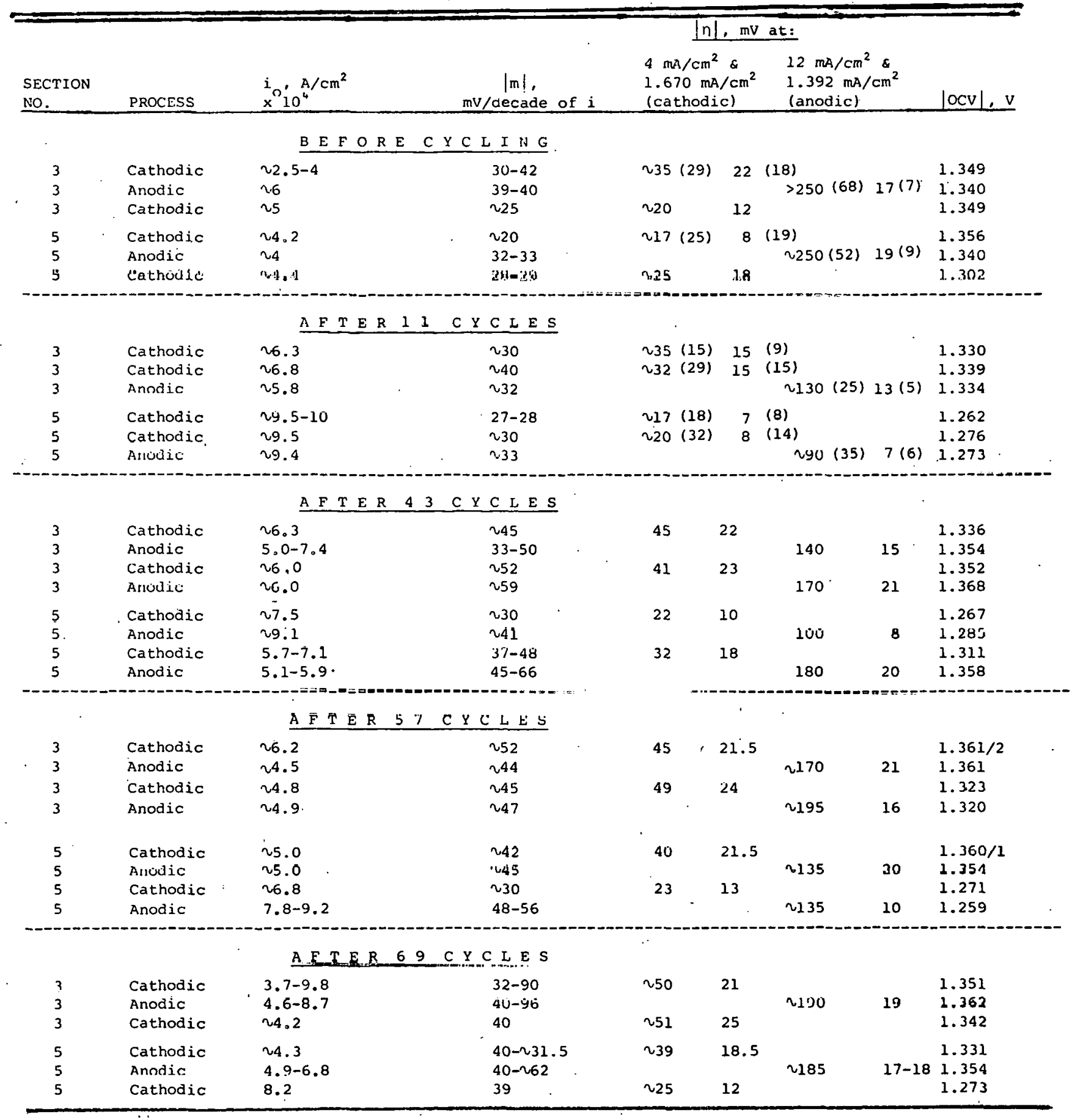

* P-IIA (in same electrolyte) appears in parentheses under first two categories. + See Figure II.l for explanation of sections. 
TABLE A:2

ELECTRODE P-IIC

(in 20\% $\mathrm{KOH}$ with $18 \mathrm{LiOH}$ )

COMPOSITION: $988 \mathrm{ZnO}, 28 \mathrm{TFE}$

\begin{tabular}{|c|c|c|c|c|c|c|c|c|}
\hline \multirow[b]{2}{*}{$\begin{array}{l}\text { SECTION } \\
\mathrm{NO} \text {. }\end{array}$} & \multirow[b]{2}{*}{ PROCESS } & \multirow[b]{2}{*}{$\begin{array}{l}i_{0} \mathrm{~A}^{\mathrm{A} / \mathrm{cm}^{2}} \\
\times 10^{6}\end{array}$} & \multirow[b]{2}{*}{$\begin{array}{c}\mid m ! \\
\text { mV/ciesace of } i\end{array}$} & \multicolumn{4}{|c|}{$n !, \mathrm{mV}$ at: } & \multirow[b]{2}{*}{$|\operatorname{locv}|, v$} \\
\hline & & & & $\begin{array}{l}4 \mathrm{~m} \\
1.6 \\
1 \mathrm{ca} \\
\end{array}$ & $\mathrm{cm}^{2}$ & $\begin{array}{l}12 \\
1.3 \\
\text { (an } \\
\end{array}$ & $1 / \mathrm{cm}^{2}-$ & \\
\hline & & $B E F$ & $C \mathrm{CLING}$ & . & & & & \\
\hline 3 & Cathodic. & $5.1-6.1$ & $34-46$ & 41 & 19 & & & 1.311 \\
\hline 3 & Anodic & $\sim 9.5$ & $v_{38}$ & & & 60 & 9 & 1.311 \\
\hline 3 & Cathodic & $\sim 4.2$ & $n_{25}$ & 25 & 17 & & & 1.305 \\
\hline 3 & Anodic & 27.6 & $\sim 32$ & . & & 60 & 9 & 1.308 \\
\hline 5 & Cathodic & 24.9 & $\sim 35$ & 34 & 18 & & & 1.301 \\
\hline 5 & Anodic & $5.5-9.5$ & $15-20$ & & & 22 & 6 & 1.300 \\
\hline 5 & Cathodic & 25.8 & $\eta_{21}$ & 22 & 15 & & & 1.296 \\
\hline 5 & Anodic & 28.8 & 230 & & & 50 & 7 & 1.300 \\
\hline
\end{tabular}

AETER 12 CYCLES

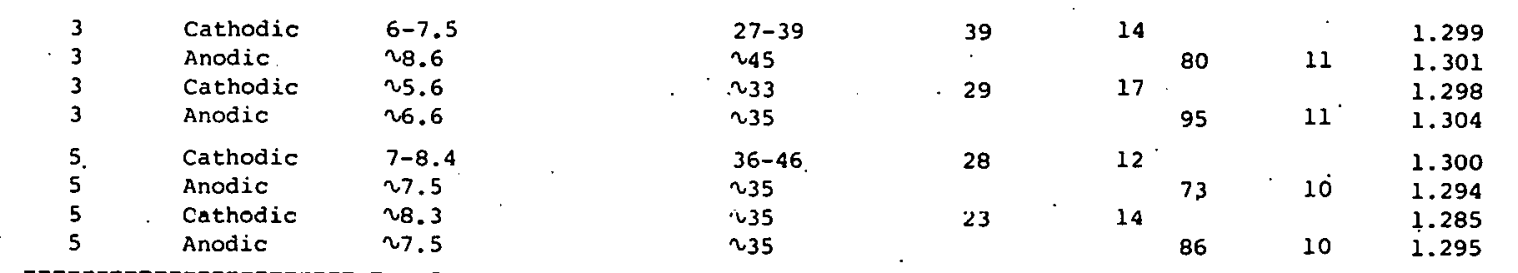

AFTER 32 CYCLES

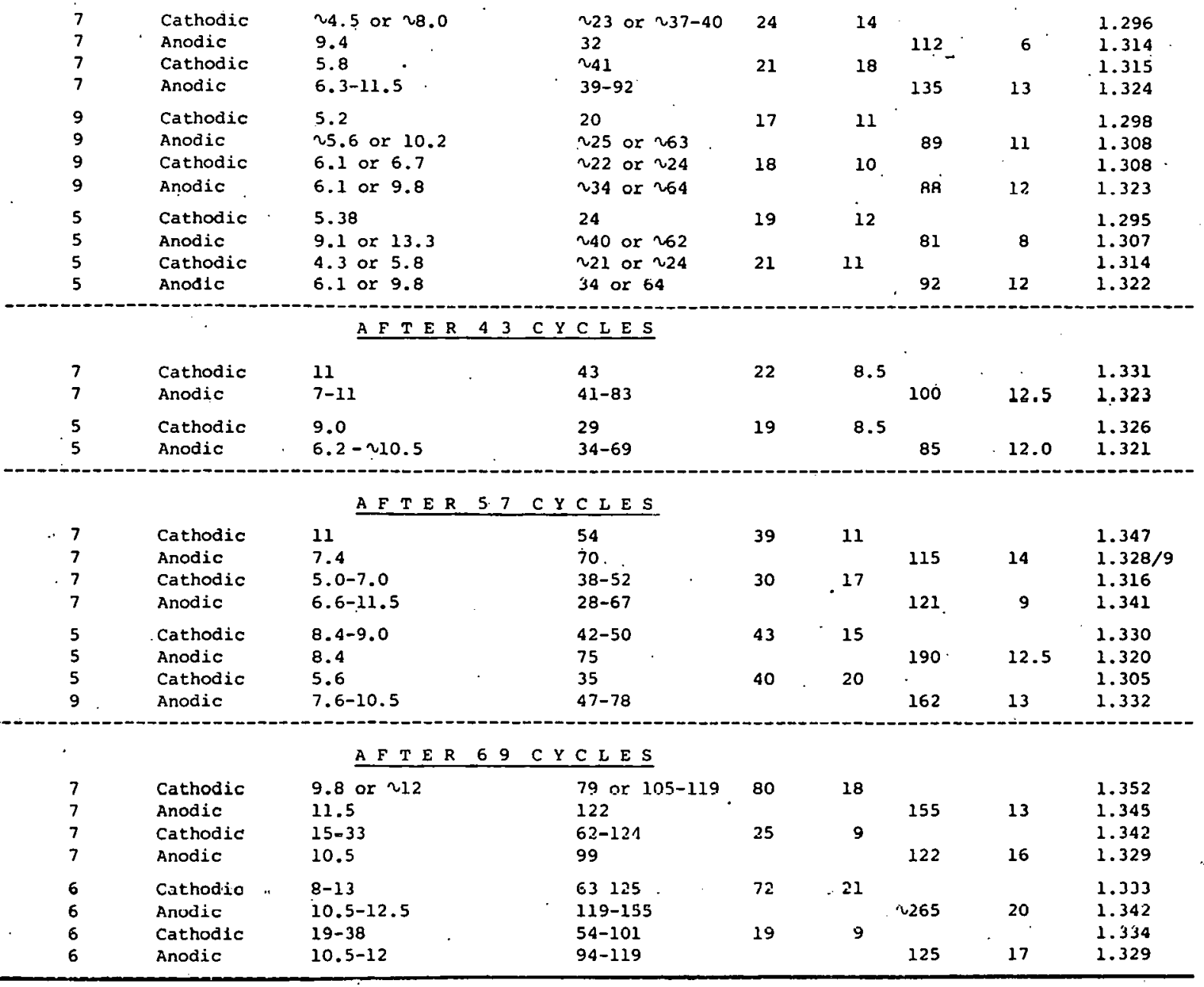


TABLE A. 3

ELECTRODE P-IID

(in $6 \% \mathrm{KOH}$ with $1 \% \mathrm{LiOH}$ )

COMPOSITION: $98 \% \mathrm{ZnO}, 2 \% \mathrm{TFE}$

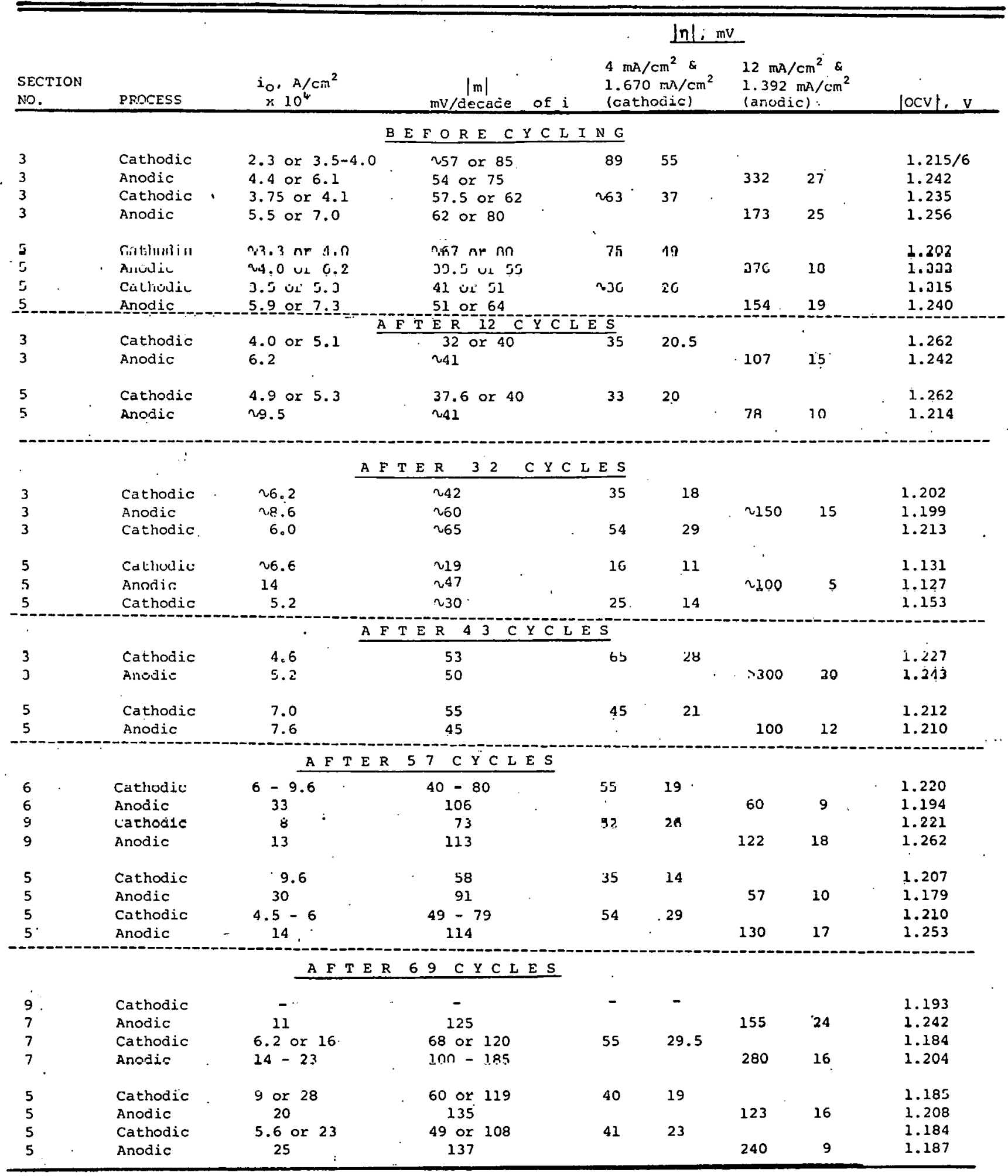


TABLE A. 4

ELECTRODE P-IIE

(in 118 KOH with $18 \cdot \mathrm{LiOH})$

COMPOSITION: $988 \mathrm{ZnO}, 28 \mathrm{TFE}$

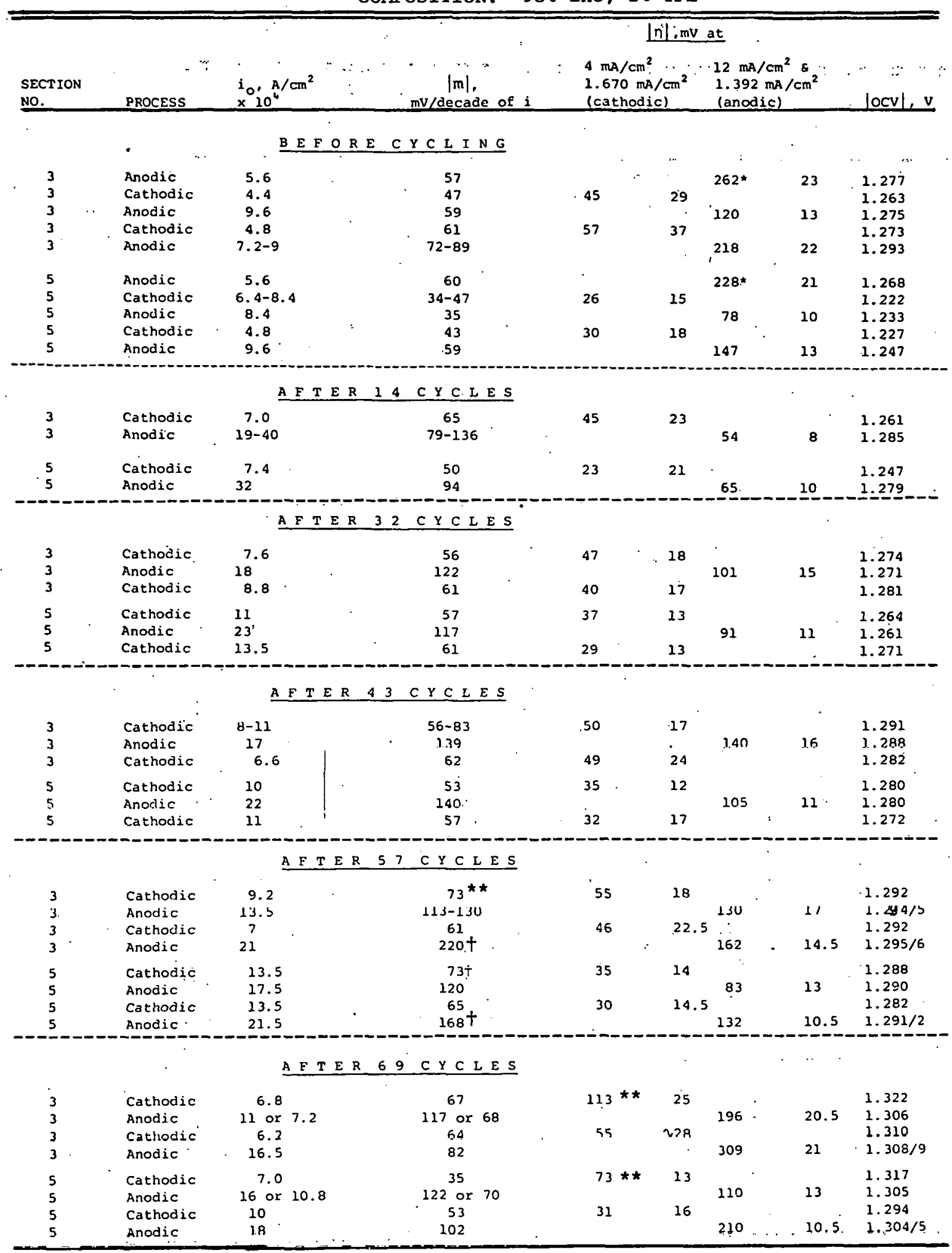

High values probably due to high degree of self dischargè. Beföre measurements, cell had been at open circuit for $\sim 60$ hrc.

* For this experiment, the rise in voltage with increase in current was more pronouged than usual, even at low currents.

+ values seem higher than they should be probably due to "reactant depletion. 
TABLE A. 5

ELECTRODE P-IIIA

(in $35 \% \mathrm{KOH}$ with $18 \mathrm{LiOH}$ )

COMPOSITION: $938 \mathrm{ZnO}_{;}, 58 \mathrm{CdO}, 28$ TFE

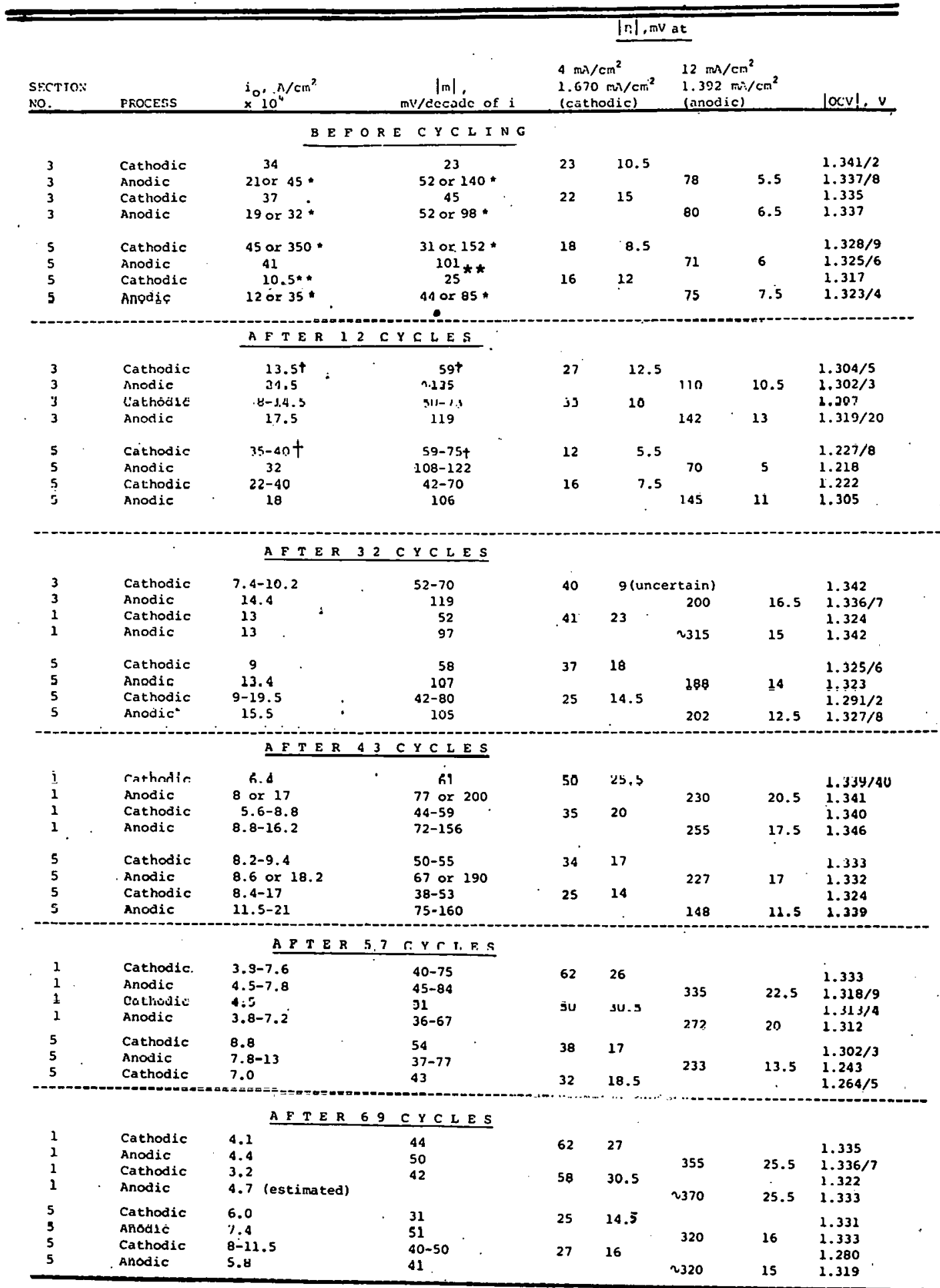

* These values depend on the points chosen to determine the Tafel slope.

** The Tafel area was probably not reached at the values of current densities used in this study, or, a short developed.

+ A sharp rise in voltage occurred prematurely and thus very few points could be used in the determination of the Tafel slope. 
TABLE A. 6

ELECTRODE P-IVA

(in $358 \mathrm{KOH}, 18 \mathrm{LiOH}$ )

COMPOSITION: 858 ZnO, 138 Mixed Oxides and 28 TFE

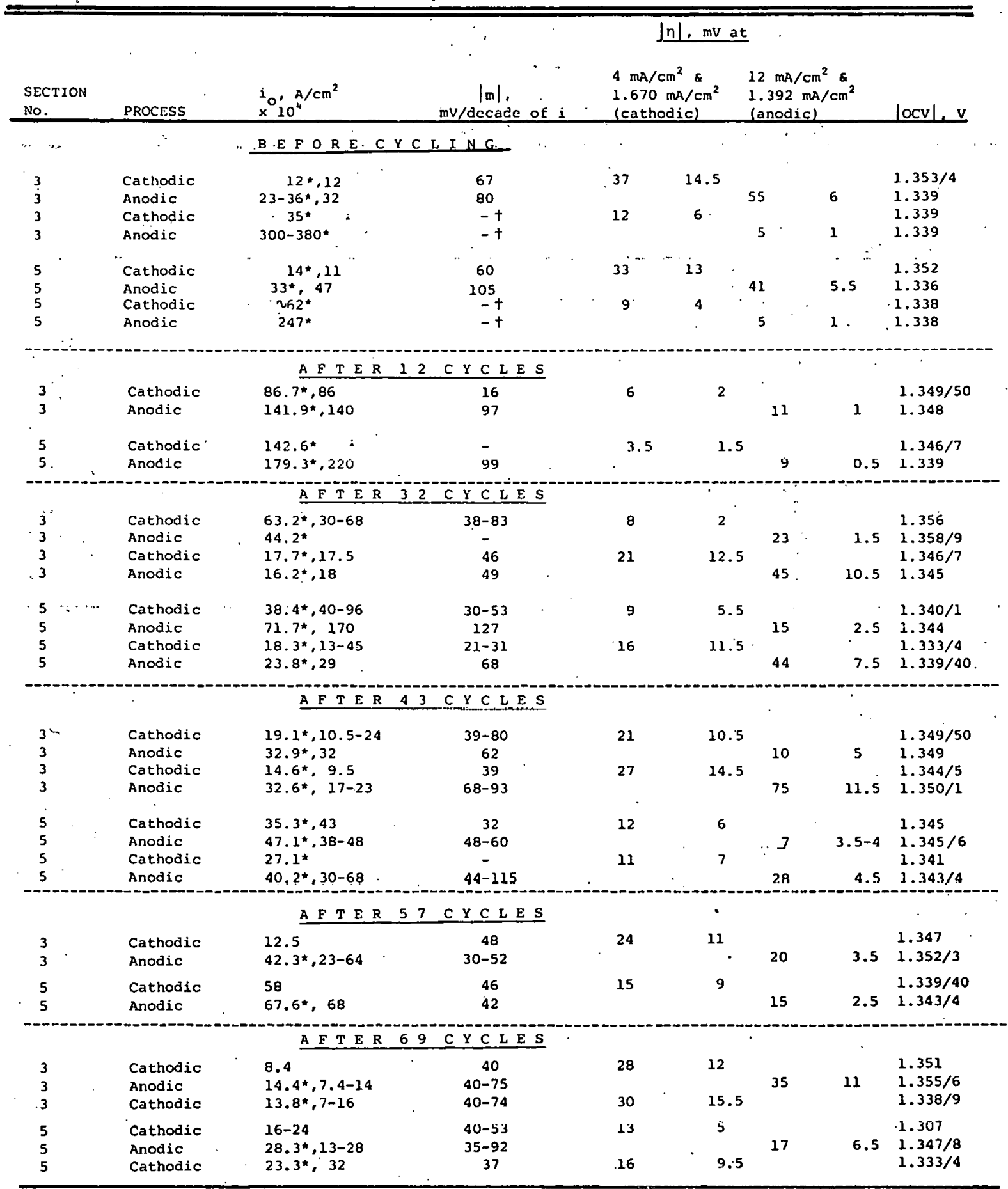

* These values were obtained from the plots of $E$ vs $i$ as opposed to the usual $E$ vs $\log i_{0}$. "In this"case, "for low values of $\eta^{\prime}$ " the slope is equal to $\mathrm{RT} / \mathrm{nFi} \mathrm{o}$ and thus ${ }^{\circ}{ }_{0}$ can be calculated from the value of the slope.

+ The Tatel region was probably not reached at the currents used in this study. (all values of $n$ were less than about $20 \mathrm{mV}$ ) 
TABLE A. 7

ELECTRODE P-VA

(in 358 with $18 \mathrm{LiOH}$ )

$898 \mathrm{ZnO}, 78 \mathrm{CdO}, 18 \mathrm{Fe}_{2} \mathrm{O}_{3}$ and $38 \mathrm{TFE}$

\begin{tabular}{|c|c|c|c|c|c|c|c|c|}
\hline \multirow[b]{2}{*}{$\begin{array}{l}\text { SECTION } \\
\text { NO. } \\
\end{array}$} & \multirow[b]{2}{*}{ PROCESS } & \multirow[b]{2}{*}{$\begin{array}{l}i_{0} \mathrm{~A} / \mathrm{cm}^{2} \\
\times 10^{4} \\
\end{array}$} & \multicolumn{5}{|c|}{$|n|, \mathrm{mv}$ at } & \multirow[b]{2}{*}{ locvl, } \\
\hline & & & $\operatorname{mv}|\mathrm{m}|$ & & $\begin{array}{l}\text { a } / \mathrm{cm}^{2} \\
\text { ic) }\end{array}$ & & $1 / \mathrm{cm}^{2}$ & \\
\hline $\begin{array}{l}3 \\
3\end{array}$ & $\begin{array}{l}\text { Calliulic } \\
\text { Anodic }\end{array}$ & $\begin{array}{l}35.8=50.9^{*} \\
38.3^{*}, 27\end{array}$ & $4 \overline{2}$ & 10 & 0 & 28 & 5 & $\begin{array}{l}1.340 \\
1.344\end{array}$ \\
\hline $\begin{array}{l}5 \\
5\end{array}$ & $\begin{array}{l}\text { Sethnotir } \\
\text { Anodic }\end{array}$ & $\begin{array}{c}34,2 * \\
39.9 *, 18-40\end{array}$ & $\begin{array}{c}= \\
10-56\end{array}$ & 11 & 6.5 & 28 & 4 & $\begin{array}{l}1.347 \\
1.343\end{array}$ \\
\hline " & & $A F T E$ & C Y C L E S & & & & & - \\
\hline $\begin{array}{l}3 \\
3 \\
3\end{array}$ & $\begin{array}{l}\text { Cathodic } \\
\text { Anodic } \\
\text { Cathodic }\end{array}$ & $\begin{array}{l}13 \\
35.1 *, 35 \\
25.7,41\end{array}$ & $\begin{array}{l}40 \\
48 \\
32\end{array}$ & $\begin{array}{l}24 \\
13\end{array}$ & $\begin{array}{l}4.5 \\
8.5\end{array}$ & 27 & 5.5 & $\begin{array}{l}1.351 / 2 \\
1: 345 / 6 \\
1.331 / 2\end{array}$ \\
\hline $\begin{array}{l}5 \\
5 \\
5\end{array}$ & $\begin{array}{l}\text { Cathodic } \\
\text { Anodic } \\
\text { Cathodic }\end{array}$ & $\begin{array}{l}23-32 \\
58.4^{\star}, 52 \\
25.2^{\star}\end{array}$ & $\begin{array}{c}35-75 \\
23 \\
-\end{array}$ & 13 & $\begin{array}{l}1.0 \\
8.5\end{array}$ & 12 & 3.0 & $\begin{array}{l}1.356 / 7 \\
1.345 \\
1.331 / 2\end{array}$ \\
\hline
\end{tabular}

* These values were obtained from plots of $E$ vs $i$, where, for low values of $n$, the slope is equal to $\mathrm{RT} / \mathrm{nF} i_{0}$. 
TABLE A. 8

COMPARISON OF POLIARIZATION DATA BEFORE CYCLING

CATHODIC PROCESS

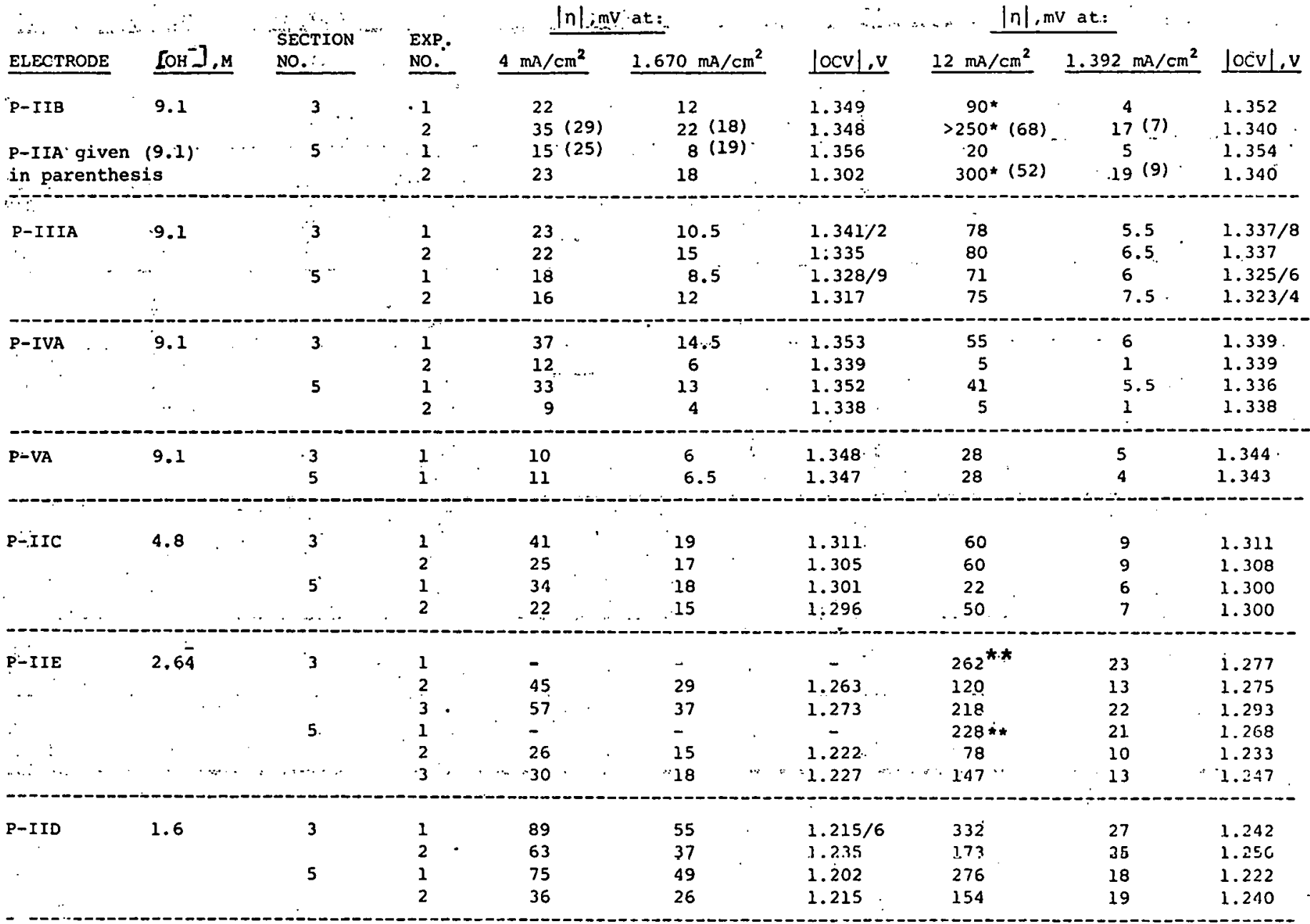

- Very sharp drops were observed in these cases after approximately $6 \mathrm{~m} \Lambda / \mathrm{cm}^{2}$, probably due to reactant depletion. These results are not considered valid.

* See note under. * for Table A.4, this report. 
TABLE A.9

COMPARISON OF POLARIZATION DATA AFTER INITIAL CYCLING

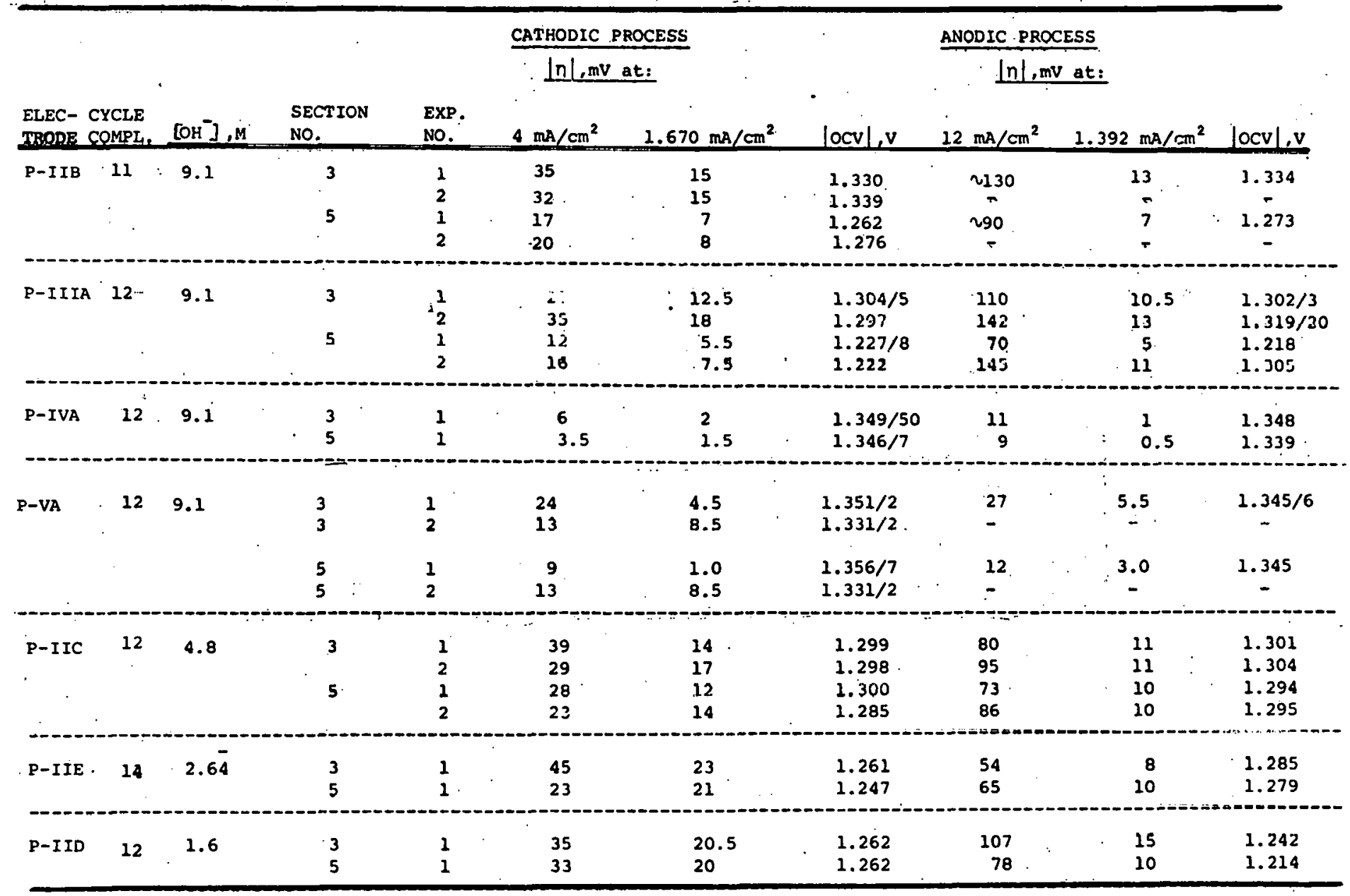


TABLE A. 10

COMPARISON OF POLARIZATION DATA AFTER 32 CÝYCLE

$\frac{\text { CATHODIC PROCESS }}{\mid \mathrm{n} l ; \mathrm{mV} \text { at: }} \quad \therefore \quad \frac{\text { ANODIC PROCESS }}{\ln \mid, \mathrm{mV} \text { at: }}$

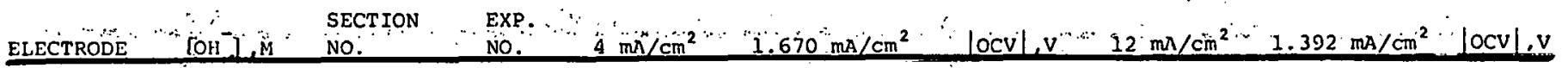

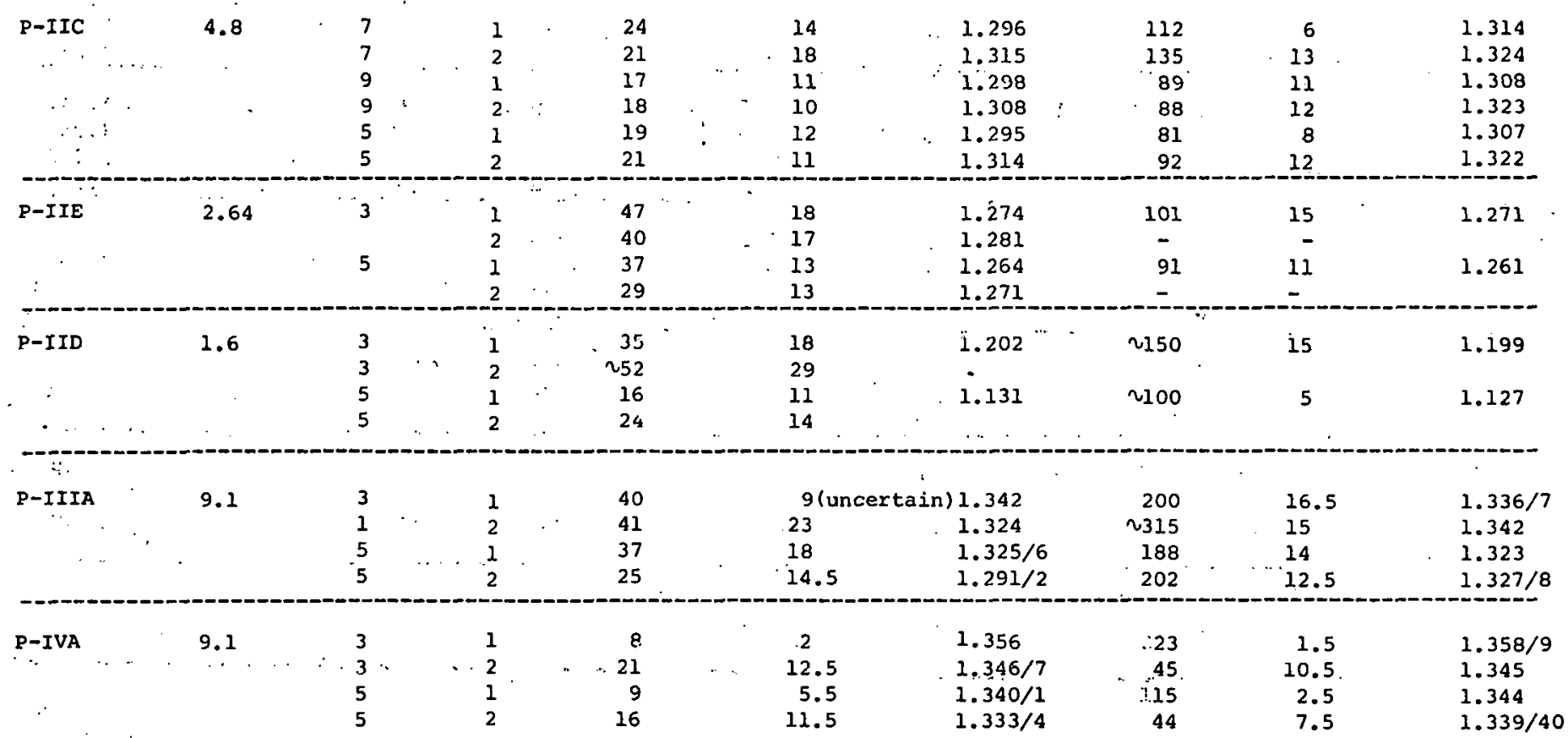


TABLE A.11

COMPARISON OF POLARIZATION DATA AFTER 43 CYCLES

\begin{tabular}{|c|c|c|c|c|c|c|c|c|c|}
\hline ELECTRODE & $\left.\mathrm{COH}^{-}\right], \mathrm{M}$ & $\begin{array}{l}\text { SECTION } \\
\text { NO. }\end{array}$ & $\begin{array}{l}\vdots \\
\text { EXP. } \\
\text { NO. }\end{array}$ & $\begin{array}{l}\frac{\text { CATHODIC }}{|\mathrm{n}|, \mathrm{ml}} \\
4 \mathrm{~mA} / \mathrm{cm}^{2}\end{array}$ & $\begin{array}{l}\text { OCESS } \\
1.670 \mathrm{~mA} / \mathrm{cm}^{2}\end{array}$ & Jocvl,v & $\frac{\text { ANODIC PRO }}{|\mathrm{n}|_{\mathrm{m}}^{\mathrm{m}}}$ & $\begin{array}{l}\text { ESS } \\
\text { at: } \\
1.392 \mathrm{~mA} / \mathrm{cm}^{2}\end{array}$ & Jocv |.v \\
\hline P-IIB & 9.1 & $\begin{array}{l}3 \\
5\end{array}$ & $\begin{array}{r}1 \\
2 \\
1 \\
2 \\
-\end{array}$ & $\begin{array}{r}45 \\
41 \\
22 \\
32 \\
-\end{array}$ & $\begin{array}{r}22 \\
23 \\
10 \\
18 \\
\end{array}$ & $\begin{array}{l}1.336 \\
1.352 \\
1.267 \\
1.311 \\
\end{array}$ & $\begin{array}{l}140 \\
170 \\
100 \\
180\end{array}$ & $\begin{array}{r}15 \\
21 \\
8 \\
20 \\
\end{array}$ & $\begin{array}{l}1.354 \\
1.368 \\
1.285 \\
1.358\end{array}$ \\
\hline D-IIIA & 9.1 & $\begin{array}{r}1 \\
1 \\
5 \\
5 \\
-\end{array}$ & $\begin{array}{l}1 \\
\mathbf{2} \\
1 \\
2 \\
-2\end{array}$ & $\begin{array}{r}50 \\
35 \\
30 \\
25 \\
-2\end{array}$ & $\begin{array}{l}25.5 \\
20 \\
17 \\
14\end{array}$ & $\begin{array}{l}1.339 / 40 \\
1.340 \\
1.333 \\
1.324\end{array}$ & $\begin{array}{l}230 \\
259 \\
227 \\
148\end{array}$ & $\begin{array}{l}20.5 \\
17.5 \\
17 \\
11.5\end{array}$ & $\begin{array}{l}1.341 \\
1.316 \\
1.3 .32 \\
1.339\end{array}$ \\
\hline P-IVA & 9.1 & $\begin{array}{r}3 \\
3 \\
\quad 5 \\
\end{array}$ & $\begin{array}{l}1 \\
2 \\
1 \\
2\end{array}$ & $\begin{array}{r}21 \\
27 \\
+\quad 12 \\
1 !\end{array}$ & $\begin{array}{c}10.5 \\
14.5 \\
6 \\
7 \\
\end{array}$ & $\begin{array}{l}1.349 / 50 \\
1.344 / 5 \\
1.345 \\
1.34 !\end{array}$ & $\begin{array}{r}10 \\
75 \\
7 \\
-28 \\
\end{array}$ & $\begin{array}{r}5 \\
11.5 \\
3.5 \\
-4.5\end{array}$ & $\begin{array}{l}1.349 \\
1.350 / 1 \\
1.345 / 6 \\
1.343 / 4\end{array}$ \\
\hline $\begin{array}{c}\text { P-IIC } \\
\cdot\end{array}$ & 4.8 & $\begin{array}{l}7 \\
5\end{array}$ & $\begin{array}{l}1 \\
1\end{array}$ & $\begin{array}{l}23 \\
19\end{array}$ & $\begin{array}{l}8.5 \\
8.5\end{array}$ & $\begin{array}{l}1.331 \\
1.326\end{array}$ & $\begin{array}{l}\sim 105 \\
\sim 90\end{array}$ & $\begin{array}{l}12.5 \\
12.0\end{array}$ & $\begin{array}{l}1.323^{\circ} \\
1.321\end{array}$ \\
\hline P-IIE & 2.64 & $\begin{array}{r}3 \\
5\end{array}$ & $\begin{array}{l}1 \\
2 \\
1 \\
2\end{array}$ & $\begin{array}{r}50 \\
49 \\
35 \\
32 \\
-\end{array}$ & $\begin{array}{l}17 \\
24 \\
12 \\
17\end{array}$ & $\begin{array}{l}1.291 \\
1.282 \\
1.280 \\
1.272\end{array}$ & $\begin{array}{c}140 \\
= \\
105 \\
-\end{array}$ & $\begin{array}{l}16 \\
11 \\
=\end{array}$ & $\begin{array}{l}1.288 \\
-- \\
1.280 \\
-=\end{array}$ \\
\hline P-IID & 1.6 & $\begin{array}{l}3 \\
5\end{array}$ & $\begin{array}{l}1 \\
1\end{array}$ & $\begin{array}{l}65 \\
45\end{array}$ & $\begin{array}{l}38 \\
21\end{array}$ & $\begin{array}{l}1.227 \\
1.222\end{array}$ & $\begin{array}{r}>300 \\
100\end{array}$ & $\begin{array}{l}20 \\
12\end{array}$ & $\begin{array}{l}1.243 \\
1.210\end{array}$ \\
\hline
\end{tabular}


TABLE A.12

COMPARISON OF POLARIZATION DATA AFTER 57 CYCLES

\begin{tabular}{|c|c|c|c|c|c|c|c|c|c|c|}
\hline \multirow[b]{3}{*}{ ELECTORDE } & \multirow[b]{3}{*}[\mathrm{OH}]{$\mathrm{M}$} & \multirow{3}{*}{$\begin{array}{l}\text { SECTION } \\
\text { NO. }\end{array}$} & \multirow{3}{*}{$\begin{array}{l}\text { EXP. } \\
\text { NO. }\end{array}$} & \multicolumn{2}{|c|}{ CATHODIC PROCESS } & \multicolumn{4}{|c|}{ NiHODIC process: } & \multirow[b]{3}{*}{$\mid r(x), x$} \\
\hline & & & & \multicolumn{2}{|c|}{ InI, mV at: } & \multicolumn{4}{|c|}{$\left|r_{1}\right|$, my at: } & \\
\hline & & & & $4 \mathrm{~m} \lambda / \mathrm{cm}^{2}$ & $1.670 \mathrm{mn} / \mathrm{cm}^{2}$ & locvi,v & $12 \mathrm{~m} / \mathrm{cm}^{2}$ & $.39 \%$ & $\mathrm{nin} / \mathrm{cm}^{2}$ & \\
\hline \multirow[t]{4}{*}{ P-IIB } & 9.1 & 3 & 1 & 45 & 21.5 & $1.362 / 1$ & 120 & & 21 & 1.361 \\
\hline & & & 2 & 49 & 24 & 1.323 & 195 & & 16 & 1.320 \\
\hline & & 5 & 1 & 40 & 21.5 & $1.360 / 1$ & 135 & & 20 & 1.354 \\
\hline & . & & 2 & 23 & 13 & 1.271 & 135 & & 10 & 1.259 \\
\hline \multirow[t]{2}{*}{ P-IIIA } & 9.1 & 3 & 1 & 62 & 26 & 1.333 & 335 & & 22.5 & $1.318 / 9$ \\
\hline & & 3 & 2 & 50 & 30.5 & $1.313 / 4$ & 272 & & 20.0 & 1.312 \\
\hline \multirow[t]{2}{*}{ 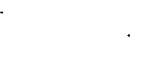 } & & 5 & 1 & 38 & 17 & i. $302 / 3$ & 233 & & 13.5 & 1.243 \\
\hline & & 5 & 2 & 32 & 18.5 & $1.264 / 5$ & 165 & & 9.0 & 1.212 \\
\hline \multirow[t]{2}{*}{ P-IVA } & 9.1 & 3 & 1 & 24 & 11 & 1.347 & 20 & & 3.5 & $1.352 / 3$ \\
\hline & & 5 & 1 & 15 & 9 & $1.339 / 40$ & 15 & & 2.5 & $1.343 / 4$ \\
\hline \multirow[t]{4}{*}{ P-IIC } & 4.8 & 7 & 1 & 39 & 11 & 1.347 & 115 & & 14 & $1.328 /:$ \\
\hline & & & 2 & 40 & 20 & 1.316 & 121 & & 9 & 1.341 \\
\hline & & 5 & 1 & 43 & 15 & 1.330 & 190 & & 12.5 & 1.320 \\
\hline & & 5 (Cath.) & 2 & 30 & 17 & 1.305 & 162 & & 13 & 1.332 \\
\hline \multirow{2}{*}{$\ldots$} & & $9(A n:)$ & & & & & & & & \\
\hline & & & & & & & & & & \\
\hline \multirow[t]{4}{*}{ P-IIE } & 2.64 & 3 & 1 & 55 & 18 & 1.292 & 130 & & 17 & $1.294 / 5$ \\
\hline & & & 2 & 46 & 22.5 & 1.292 & 162 & & 14.5 & $1.295 / 6$ \\
\hline & & 5 & 1 & 35 & 14 & 1.288 & 83 & & 13 & 1.290 \\
\hline & & & 2 & 30 & 14.5 & 1.283 & 132 & & 10.5 & $1.291 / 2$ \\
\hline \multirow[t]{4}{*}{$P-I I T D$} & $1.6 \%$ & 6 & 1 & $55 \cdots$ & $\therefore 9$ & 1.220 & $\cdots \quad 60^{\circ}$ & & 9 & 1.194 \\
\hline & & 9 & 2 & 52 & 26 & 1.221 & 122 & ' & 18 & 1.262 \\
\hline & & 5 & 1 & 35 & 14 & 1.207 & 57 & . & 10 & 1.179 \\
\hline & & & 2 & .54 & 29 & 1.210 & .130 & & 17 & 1.25 .3 \\
\hline
\end{tabular}


TABLE-A.13

COMPARISON OF POLARIZATION DATA AFTER 69 CYCLES CATHODIC PROCESS

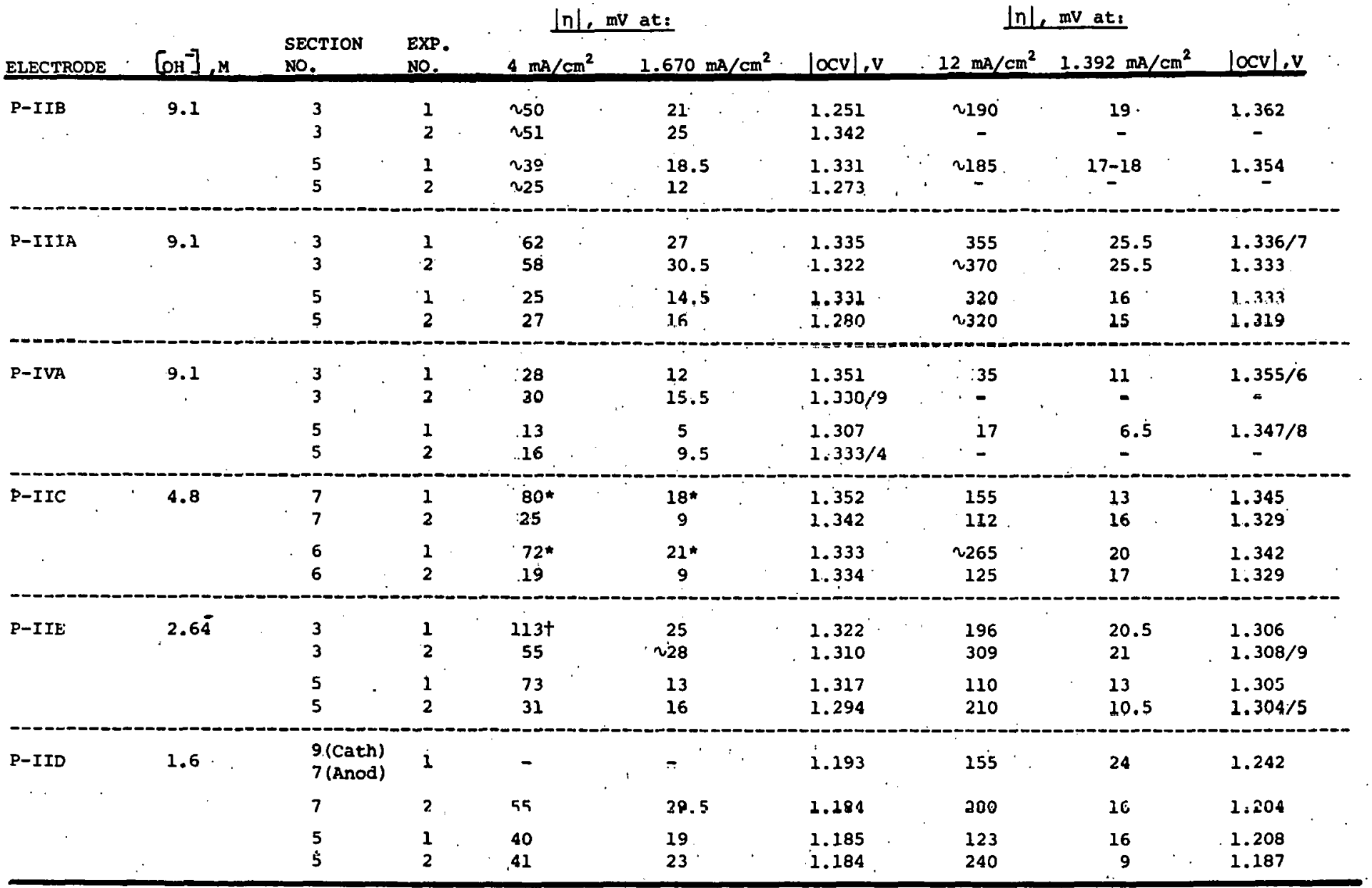

* Early gassing is presumed to have caused the high $n$ value (compare with result from Experiment No. 2).

** See note under ** for Table A.4, this report 


\section{SECTION IV \\ SEPARATOR DEVELOPMENT FOR \\ NICKEL-ZINC CELLS - (TASK III)}

Page No. 73 


\subsection{INTRODUCTION}

Separators which are used in secondary batteries have two primary functions; To keep positive and negative plates physically apart so electronic current will be constrained to flow outside the cell; and to allow ionic transport in the electrolyte between plates, as necessary. These functions lead to the following requirements and objectives for the separator:

- physically and chemically stable in the cell environment,

- Low electrical resistance,

- retards shape change of the zinc electrode and dendritic growth.

To meet the first requirement, organic or inorganic material proposed for the separator should be chemically inert and not sweil in the electrolyte. To satisfy the second requirement, it is necessary to have material which swells in the electrolyte or possesses a large pore size. The mechanism of shape change of the negative electrode and zinc dendritic growth are not fully understood but it is possible to formulate two main properties for the separator material which are desirable: To prevent zinc diffusion through the separator; and create conditions for uniform zinc deposition on the negative electrode during battery charging. Reduction of the zinc diffusion rate can be achieved by a separator material which swells in electrolyte. In this case the separator works as a selective membrane. Another way to prevent $z$ inc penetration is to produce the separator material with a uniform pore size which is smaller than the diameter of $\mathrm{Zn}(\mathrm{OH}){ }_{4}$ ions and larger than $\mathrm{OH}^{-}$ion. 


\section{ENERGY RESEARCH CORPORATION}

Analysis of these requirements indicates that the material should possess properties which are not necessarily compatible:

- to swell and have high chemical and physical stability

- to be easily permeable for $\mathrm{OH}^{-}$and impermeable for the $\mathrm{ZnO}_{2}=$ ion; however the ions are almost the same size $\mathrm{COH}^{-}=15 \AA$; $\mathrm{ZnO}_{2}=20$ to $25 \AA$ ).

Therefore attempts to produce separator material focused on three areas:

1. To make a wettable separator, with membrane type permeability which can prevent rapid zinc penetration but which is not stable in an electrolyte environment (cellulosics and PVA separators).

2. To produce microporous non-wettable separator material with capillary type permeability. This class of separator materials is stable in the electrolyte environment but cannot prevent zinc penetration, (polyethylene (polypropylene-based separators):

3. To produce a family of separator materials which combines properties of both classes. This was achieved by grafting or coating wettable polymer on a non-wettable porous matrix. These separator materials exhibit improved properties but are much more expensive and are still limited in durability by degradation of the wettable layer.

ERC production of separator materials has concentrated on

several areas:

- improving the chemical and physical stability of PVA material by crosslinking with different reagents.

- formation of a microporous separator which has excellent stability in the electrolyte environment.

- creating a polymer-based separator material which has uniform properties.

ERC has found a new way to produce material possessing the overall desired properties: The separator is formed as a thin film from a polymex blend solution which contains a polymer matrix, and uniformly incorporated in this matrix is a wettable polymer. Variation of composition and formation parameters allows production 


\section{ENERGY RESEAACH CORPORATION}

of films with a wide range of properties.

ERC has concluded that, together with creating a separator material, it is necessary to design a separator system which can combine all the desired properties and will not be expensive to produce.

optimum design of the separator system and separator material should be based on an understanding of the processes occurring in the battery over a large number of cyclic tests under real cell conditions.

Basic work in developing several new compositions and in improving existing materials to meet requirements for separator films in Ni-Zn batteries has already been reported. The most important laboratory tests for evaluation of the separator materials were also developed.

The goals of research efforts during this year were:

- improvements in composition and production technology of the separator materials previously devcloped.

- study of the work conditions and failure modes of various $\mathrm{Ni}$ Zn cells containing different components.

- creation of new separator systems which substantially increase the cycle life of $\mathrm{Ni}-\mathrm{Zn}$ cells.

\subsection{TECHNICAL DISCUSSION}

2.1 IMPROVED COMPOSITION AND PRODUCTION TECHNOLOGY FOR CROSSLINKED PVA SEPARATOR FILMS

Commercially available PVA films which are used in alkaline batteries show low electrical resistance but poor long-term stability in the electrolyte environment. Attempts to improve the chemical stability by crosslinking have led to increased brittleness and cracking of the separator film. Therefore, 


\section{ENERGY AESEARCH CORPORATION}

employing a crosslinking agent which can correct the chemical deficiencies and not aggravate mechanical properties of PVA should increase the cycle life of the cell.

\subsubsection{Various Compositions for Improved Crosslinked PVA} Separator

Crosslinked PVA films were prepared by film casting on a metal sheet utilizing doctor blades. PVA was crosslinked by reaction with:

1. A mixture of dimethylol urea (DMU) and boric acid

2. Only boric acid

3. Only DMU

4.. Heating in oper air

Films were evaluated for various properties prior to testing. in cells with only one layer of separator film. Results of the evaluation are given in Tables III.l through III.3. Stability of mechanical properties in KOH for PVA based films was also détermined. Different films were tested before and after exposure in $\mathrm{KOH} . "$ Tensile strength and defiection were measured (see Table III.3).

Results of testing PVA based separator films (Table III.3) indicated that the best properties are obtained with PVA films which were crosslinked by a mixture of DMU and boric acid. PVA crosslinked only by DMU exhibited excessive swelling. Both of the films show an increase in cycle life in cells with only one layer of separator.

Another variation was tested in which PVA was crosslinked by reaction with sucrose and DMU and by heating in air. A filler was added to reduce swelling and wrinkling of PVA films in $\mathrm{KOH}$. Another method ${ }^{1}$ was usea for crosslinking a PVA and sucrose blend. 
TABLE III. 1

CHARACTERISTICS OF VARIOUS PVA FILMS

\begin{tabular}{|c|c|c|c|c|c|}
\hline \multirow[b]{2}{*}{ COMPOSITON } & \multicolumn{2}{|c|}{ ELECTRICAL RESISTANCE DATA } & \multirow{2}{*}{$\begin{array}{c}\text { DEGREE OF } \\
\text { CROSSLINKING } \\
q\end{array}$} & \multirow[b]{2}{*}{$\begin{array}{l}\text { MEASURING } \\
\text { CONDITIONS }\end{array}$} & \multirow[b]{2}{*}{ COMMENTS } \\
\hline & $\begin{array}{l}\text { ELECTRICAL RESIS., } \\
\mathrm{m} \Omega \cdot \mathrm{in}^{2} / \mathrm{mil} .\end{array}$ & COMMENTS & & & \\
\hline $\begin{array}{l}\text { PVA + DMU } \\
903+108\end{array}$ & $40-60$ & $\begin{array}{l}\text { Film } \\
\text { Turns } \\
\text { Brown }\end{array}$ & $85-90$ & $\begin{array}{l}\text { Heated at } \\
130^{\circ} \mathrm{C} \text { in } \\
\text { Vacuum oven } \\
\text { for } 3 \mathrm{hre} \text {. }\end{array}$ & $\begin{array}{l}\text { Not soluble in } \\
\text { water, only } \\
\text { swells. }\end{array}$ \\
\hline $\begin{array}{l}P V A+B A^{*} \\
87 \%+13 \%\end{array}$ & $40-50$ & $\begin{array}{l}\text { Turns } \\
\text { less } \\
\text { brown }\end{array}$ & $\begin{array}{l}\text { Soluble } \\
\text { in water }\end{array}$ & $"$ & $\begin{array}{l}\text { Dissolved in } \\
\text { water }\end{array}$ \\
\hline $\begin{array}{l}\mathrm{PVA}+\mathrm{DMU}+\mathrm{BA} \\
87 \%+8.5 \% \div \\
+4.5 \%\end{array}$ & $50-75$ & $\begin{array}{l}\text { Turns } \\
\text { less } \\
\text { brown }\end{array}$ & $85-90$ & $"$ & $\begin{array}{l}\text { Not soluble in } \\
\text { water, only } \\
\text { swells. }\end{array}$ \\
\hline $\begin{array}{l}\text { COMMERCIAL } \\
\text { PVA }\end{array}$ & $30-50$ & $\begin{array}{l}\text { Turns } \\
\text { brown }\end{array}$ & $70-80$ & $\begin{array}{l}\text { Heated at } \\
130^{\circ} \mathrm{C} \text { until } \\
\text { it turned } \\
\text { jruwn }\end{array}$ & $"$ \\
\hline
\end{tabular}

* Boric Acid

t All films had a dry thickness of 2.0-2.5 mil. and were aged at $50^{\circ} \mathrm{C}$ for 4 days. 
TABLE III. 2

TESTING OF VARIOUS PVA FILMS

\begin{tabular}{|c|c|c|c|c|c|}
\hline \multirow[b]{2}{*}{ COMPOSITION } & \multicolumn{2}{|c|}{ TENSILE HANGING TEST } & \multicolumn{3}{|c|}{ WATER ABSORPTION TEST } \\
\hline & $\begin{array}{c}\text { NO. OF } \\
\text { DAYS }\end{array}$ & COMMENTS & $\begin{array}{l}\text { \% WT. } \\
\text { GAIN }\end{array}$ & CONDITIONS & COMMENTS \\
\hline COMMERCIAL PVA & $3-4$ & Film turned brown & 40.90 & $\begin{array}{l}\text { Heated at } \\
135^{\circ} \mathrm{C} \text { until } \\
\text { it turned } \\
\text { brown. }\end{array}$ & $\begin{array}{l}\text { Not soluble in } \\
\text { water, only swells. }\end{array}$ \\
\hline $\begin{array}{l}\text { PVA + DMU } \\
90 \%+10 \%\end{array}$ & $8-9$ & Film turned brown & 32.83 & $\begin{array}{l}\text { Heated at } \\
135^{\circ} \mathrm{C} \text { for } \\
2 \text { to } 3 \text { hrs. }\end{array}$ & $\begin{array}{l}\text { Swells but not } \\
\text { solbule. }\end{array}$ \\
\hline $\begin{array}{l}P V A+B A * \\
87 \%+13 \%\end{array}$ & $3-6$ & $\begin{array}{l}\text { Film turned less } \\
\text { brown }\end{array}$ & $\begin{array}{l}\text { Soluble } \\
\text { in water }\end{array}$ & $\begin{array}{l}\text { Heated at } \\
135^{\circ} \mathrm{C} \text { for } \\
2 \text { to } 3 \text { hrs. }\end{array}$ & $\begin{array}{l}\text { Dissolved in water. } \\
\text { Film very brittle. }\end{array}$ \\
\hline $\begin{array}{l}\mathrm{PVA}+\mathrm{DMU}+\mathrm{BA} \\
87 \%+8.5 \%+4.5 \%\end{array}$ & $8-9$ & $\begin{array}{l}\text { Film turned less } \\
\text { brown. }\end{array}$ & 34.79 & $\begin{array}{l}\text { Heated at } \\
130^{\circ} \mathrm{C} \text { in } \\
\text { oven for } \\
2 \text { to } 3 \text { hrs. }\end{array}$ & $\begin{array}{l}\text { Swells only. Not } \\
\text { soluble. }\end{array}$ \\
\hline
\end{tabular}

* Boric Acid

+ Conditions: $45 \% \mathrm{KOH}$ at $65^{\circ} \mathrm{C}$; hanging length of film was $1-1 / 2$ to 2 inches. 
TABLE III. 3

TENSILE STRENGTH AND DEFLECTION OF VARICUS PVA FILMS

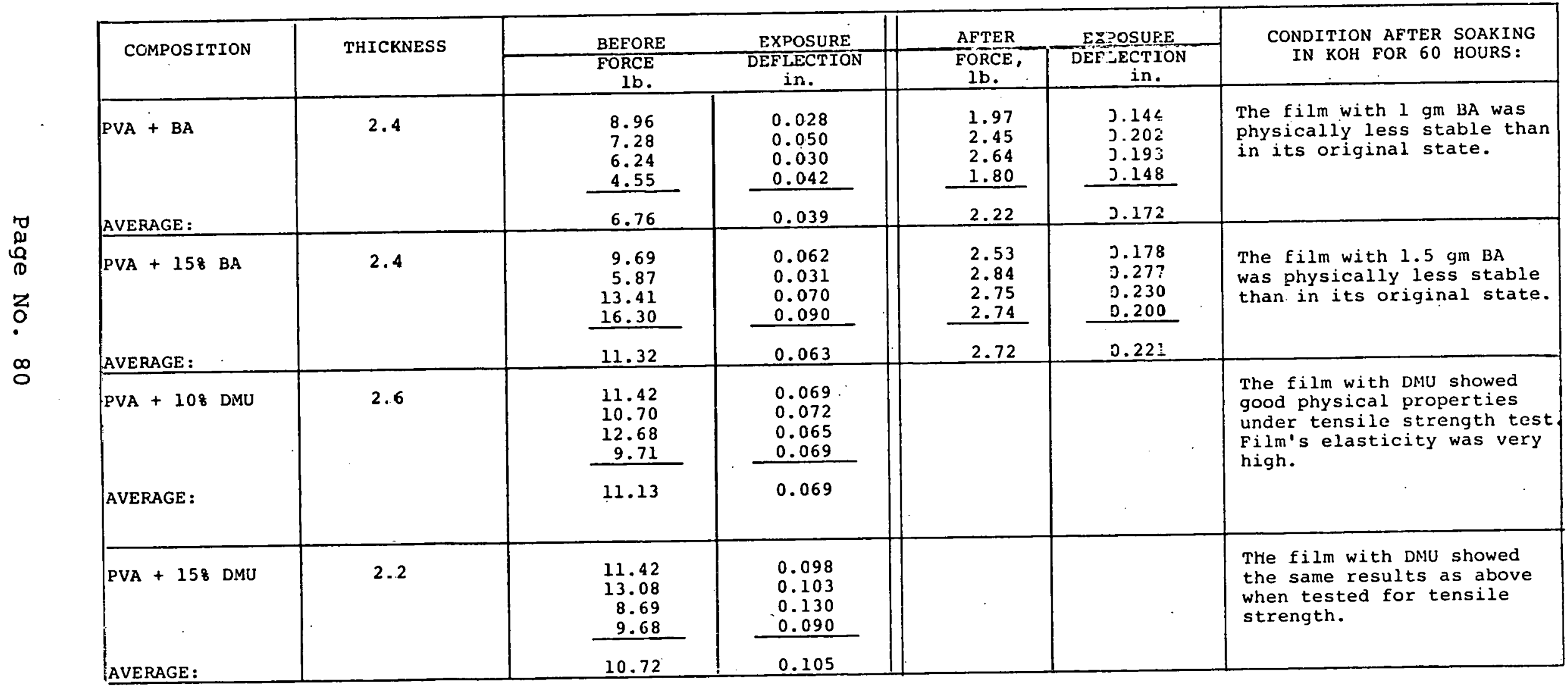


A PVA film containing 5을 sucrose was post-treated and crosslinked by the following method: $200 \mathrm{~g}$ of $\mathrm{Na}_{2} \mathrm{SO}_{4}$ was added to one liter of water along with $20 \mathrm{cc}$ of $\mathrm{H}_{2} \mathrm{SO}_{4}$. The film was treated with this solution for 15 minutes, then washed thoroughly with water and dried at room temperature. Because the film swells somewhat during washing and wrinkles during drying, it is difficult to make bags from this film. Therefore, the zinc electrode was coated with PVA solution + 5\% sucrose.

Measurements of electrical resistance and durability in $\mathrm{KOH}$ for PVA based films are given in Tables JII.5 and III.6. Results obtained indicate that the degree of crosslinking was low for all films tested. Electrical resistance and stability in $\mathrm{KOH}$ is almost the same for different PVA based compositions. Cells with these separator films were tested and the results, given in Table III.4, indicate that the shape change of the $\mathrm{zn}$ electrode depends on the degree of swelling of the separator material. Addition of the filler resulted in reduction of the degree of swelling and shape change in the $\mathrm{Zn}$ electrode. But cycle life of the colle did not insrease hecause zinc dendrites grew through the separator. This fact is probably related to low adhesion between PVA polymer and filler. Therefore, space for $\mathrm{zinc}$ dendrites to grow was created around the particles of the filler.

In another attempt to increase chemical stability, PVA was crosslinked by reaction with glutraldehyde and p-phenylenediamine. 
TABLE III. 4

TEST RESULTS FOR SMALL CELLS

\begin{tabular}{|c|c|c|c|c|c|c|c|c|}
\hline & & THEO. & & & $\mathrm{CHG/}$ & & & \\
\hline LECTRODE & ELECTRODE & $\mathrm{ZINC}$ & SEPARATOR & & DSCH . & & PAILURE & \\
\hline TYPE \& NO. & SIZEＩIN. & $\mathrm{CAP}(\mathrm{AH})$ & CONF IGURAT ICN & DISCHARGE. & RATIO, & CYCLE & MDE & COMMENTS \\
\hline
\end{tabular}

(1) 2 Full Sintered $\mathrm{Ni}$

1 Full zinc

$\mathrm{ZnO}-93 \%$
$\mathrm{CdO}-5 \%$

TFE - 28

$\mathrm{H}-3-7 / 8$

$\mathrm{W}-2-7 / 8$ "

$\mathrm{T}-.07 "$

(2) SAME

SAME

SAME

linked with

$.5 \mathrm{~A} \times 1 \mathrm{hr} .120$

42

Finhole

- I layer

15\% Boric Acid

(3) SAME

SAME

SAME

PVA cross-

linked with

108-20\%,DMU

SAME

42

Smal1

Pinhole

要

Z (4) 2 Full sintered Ni 1 Full Zinc

$\infty$

$\begin{array}{ll}\text { ZnO }-938 & \mathrm{H}-3-7 / 8^{\prime \prime} \\ \text { CdO }-58 & \mathrm{~W}-2-7 / 8^{\prime \prime} \\ \text { TFE }-28 & \mathrm{~T}-.07^{\prime \prime}\end{array}$

14.4

One layer 2

mil thick PVA

cross-linked with

128 Boric Pcid

(5) SAME

SAME

SAME

$1.8 \mathrm{mil} \mathrm{trick}$

SAME

film - one

layer of FVA.

vis. $(28-32 \mathrm{cp})$

$2.5 \mathrm{~A} \times 1 \mathrm{hr} .120$

52

Dendrite

Growth

Film looks brittle. No change in color.

brown. Shape of zinc electrode has been changed, dendrite growth.

Film swells less than commercial PVA. Turned slightly brown, cracked from edges.

Swells, turned slightly brown but still had good

strength. Zinc electrodes shape changed in a way and film swelled.

1 layer $1.9 \mathrm{mil}$

thick PVA cross-

linked with $15 \%$

Boric Acid and

filtered before

casting

(7) SAME

SAME

SAME

$1.7 \mathrm{mil}$ thick SAME

- 1 layer of high

mol.wt. PVA, vis.

SAME

SAME

45

Dencirite

Growth

through

sides

Film swells, little change in color

SPME

(52-65 cP)

very

small

one

pininole
Swells less, turns less brown, little change in shape of zinc electrode. 
TABLE III. 4

TEST RESLILTS FOR SMALL CELLS

ELECTFODE

TYPE \& NO.

2 Full Sintered $\mathrm{Ni}$

1 Full Zinc

$$
\begin{aligned}
& \text { ZnO - 938 } \\
& \text { CdO - } 58 \\
& \text { TFE - } 28
\end{aligned}
$$

(9) SAME

(10) SAME

$\infty$

(11) SAME

(12) SAME
THEO.

ELECTRODE ZINC SEPARATOR

SIZE/IN. CAP. (AH) CONFIGURATION

$H-3-7 / 8^{\prime \prime} \pm$

$1 / 16$

ง $-2-7 / 8+$

$1 / 16$

T-.07"

$.002^{\prime \prime}$

SAME

SAME

FVA + DMU

Cne layer

$90 \%+10 \%$

SAME

SAME

one layer of (PVA + Boric facid)

$87 \%+13 z$

SAME: SAME

One layer of

(PVA + Boric

Acid + DMU)

$878+4.58+$

$8.58)$

SAME

one layer of

\section{DISCHARGE}

CHG/

DSCH.

RATIO $\%$ CYCLE MODE

MODE

$2.5 \mathrm{~A} \times 1 \mathrm{hr} .120$

60

Pinhole

in $\mathrm{film}$

SAME

SAME

75

SAME

SAME

SAME

68

Pinehole

in $\mathrm{film}$

SAME

SAME

PVA on neg-

ztive plate

PVA + filler

$70 \%+30 \%$

$$
\begin{aligned}
& \text { th } \\
& \text { in } \\
& \text { Fi }
\end{aligned}
$$

There was not any shape

change in negative electrode. 


\section{ENERGY RESEARCH CORPOAATION}

TABLE III. 5

ELECTRICAL RESISTANCE OF PVA-BASED FILMS

\begin{tabular}{|c|c|c|c|c|}
\hline & COMPOSITION & $\begin{array}{c}\text { THICKNESS } \\
\text { MIL. }\end{array}$ & $\begin{array}{c}\text { DAYS IN } \\
\mathrm{KOH}\end{array}$ & $\begin{array}{l}\text { ELECTRICAL } \\
\text { RESISTANCE } \\
M \Omega \cdot i n^{2} / \mathrm{mil}\end{array}$ \\
\hline PVX & + sucrose & $2.0-2.5$ & 4 & 10 \\
\hline 889 & $+12 \%$ & & & \\
\hline $\begin{array}{l}\text { PVA } \\
70 \%\end{array}$ & $\begin{array}{l}+ \text { filler } \\
+30 \%\end{array}$ & 1.5 & 7 & 15 \\
\hline $\begin{array}{l}\text { PVA } \\
65 \%\end{array}$ & $\begin{array}{l}+\mathrm{DMU}+\mathrm{Eiller} \\
+5 \%+30 \%\end{array}$ & 2.5 & 5 & 25 \\
\hline $\begin{array}{l}\text { PVA } \\
83 \%\end{array}$ & $\begin{array}{l}+ \text { DMU } \\
+12 \%\end{array}$ & 2.5 & 5 & 25 \\
\hline $\begin{array}{l}\text { Brow } \\
\text { Comm }\end{array}$ & $\begin{array}{l}\text { Nn, post-treated } \\
\text { nercial PVA }\end{array}$ & 1.5 & 5 & 35 \\
\hline $\begin{array}{l}\text { PVA } \\
75 \%\end{array}$ & $\begin{array}{l}+ \text { filler } \\
+25 \%\end{array}$ & 1.9 & 1 & 25 \\
\hline $\begin{array}{l}\text { FVA } \\
75 \%\end{array}$ & $\begin{array}{l}+ \text { fillel + DHU } \\
+20 \%+5 \%\end{array}$ & 2.0 & 2 & 15 \\
\hline $\begin{array}{l}\text { PVA } \\
95 \%\end{array}$ & $\begin{array}{l}+ \text { Sucrose } \\
+5 \%\end{array}$ & 1.5 & 1 & 15 \\
\hline
\end{tabular}


TABLE III. 6

TENSILE HANGING TEST FOR PVA-BASED FILMS

\begin{tabular}{|l|r|r|}
\hline \multicolumn{1}{|c|}{ COMPOSITION } & TIME IN KOH & COMMENTS \\
\hline $\begin{array}{l}\text { Post-treated brown } \\
\text { Commercial PVA } \\
\text { Commercial PVA }\end{array}$ & 4 days \\
PVA + Eiller & $3-4$ days & stretched \\
$75 \%+25 \%$ & stretched \\
PVA + filler + DMU & 4 days \\
$75 \%+20 \%+5 \%$ & $4-5$ days & stretched \\
& & stretched slightly \\
\hline
\end{tabular}




\section{ENERGY RESEARCH CORPORATION}

The following method of crosslinking was used: $25 \mathrm{~g}$ of high molecular weight PVA was dissolved in $500 \mathrm{cc}$ of water at $50^{\circ} \mathrm{C}$ and cooled to $20^{\circ} \mathrm{C}$. Then $0.1 \mathrm{~g}$ of gluteraldehyde was added as $5 \%$ aqueous solution and $0.1 \mathrm{~g}$ of p-phenylenediamine anti-oxidant. The ph was adjusted to 2 with $\mathrm{H}_{2} \mathrm{SO}_{4}$. The film was cast on a glass sheet and dried in an oven at $100^{\circ} \mathrm{C}$ for 15 minutes. The PVA film obtained is not soluble but swells in water.

Electrleal reslstance of these crusslinked PVA fllms was measured and is given in Table. III.7. Results obtained show that the degree of crosslinking is not high and the quality of the film is not good. Data from the tensile hanging test (see Table III.8) verify these observations.

2.1 .2 zinc Penetration Test

The zinc penetration test was established for better characterization of the separator materials.

\section{Apparatus and Frocedure}

The test equipment consists of a cell assembly which holds the separator being investigated between two zinc electrodes: One serves as the anode, the other as the cathode. The use of zinc instead of silver for the anode avoids possible silver attack and contamination, and provides for replenishment of the zincate as the plating proceeds. Current is passed between the electrodes at a controlled current density until a zinc trail traverses the separator; for a single test, this distance traversal can be detected optically, but for mass testing, it is more conveniently detected electronically. 
TABLE III. 7

ELECTRICAL RESISTANCE OF PVA FILMS

CROSSLINKED WITH GLUTARALDEHYDE

AND P-PHENYLENEDIAMINE

\begin{tabular}{|l|c|c|c|}
\hline COMPOSITION & $\begin{array}{l}\text { THICKNESS } \\
\text { Mil. }\end{array}$ & $\begin{array}{c}\text { DAYS IN } \\
\text { KOH }\end{array}$ & $\begin{array}{c}\text { ELECTRICAL } \\
\text { RESISTANCE }\end{array}$ \\
& & & $\mathrm{m} \Omega^{\circ}$ in $^{2} / \mathrm{mil}^{\prime}$ \\
& & 2 & 20 \\
ERC PVA+ & 1.5 & 5 & 5 \\
Glutaraldehyde + & & 11 & 45 \\
P-phenylenediamine & & 12 & 20 \\
& & 14 & 5 \\
& & 17 & 5 \\
& & 20 & 5 \\
\hline
\end{tabular}

TABLE III. 8

TENSILE HAINGING TEST FOR PVA FILMS

CROSSLINKED WITH GLUTARALDEHYDE

AND P-PHENYLENEDIAMINE

\begin{tabular}{|c|c|c|c|}
\hline COMPOSITION & TIME & STAYED & \\
\hline $\begin{array}{l}\text { Film } \\
\text { Commercial PVA } \\
\text { ERC PVA } \\
\text { PVA + Glutaraldehyde } \\
+ \text { P-Phenylenediamine } \\
\text { ERC Polymer Blend }\end{array}$ & & $\begin{array}{l}\text { days } \\
2 \text { weeks }\end{array}$ & \\
\hline
\end{tabular}




\section{ENERGY RESEARCH CORPORATION}

Figure III.l shows the test cell. In preparation for a test, a disc of paper is die cut and the separator is cut along a template to the shape shown in segment $A$ of the figure. The separator and disc are soaked for 24 hours in a solution prepared by adding $76.5 \mathrm{~g}$ of zinc oxide (USP) to a liter of $44 \% \mathrm{KOH}$ solut.ion.

To start the assembly, sheet of zine (99.98 gradc) is inserted in the notch in the dnule comparlment and the wet piece of Viskon paper is lifted with tweezers from the soaking vessel and placed on the inner end of the cyclindrical zinc cathode. The four threaded rods are put through the anode compartment which is then placed with outer face downward on the table. Sections are successively placed in position in the order shown in the exploded view (Segment A). The wet separator is handled by the edges with two pairs of tweezers to avoid marring the test area.

After assembly, the test cell is placed in the upright position and the anode compartment is filled with the above solution. It should be noted that the only electrolyte in the cathode compartment is that held by the paper.

The assemhly, even when tightly rompressed, is not. rompletely liquid-tight. Each test cell is thereafter placed in a separate plastic dish for the obvious purpose of holding the leakage, but also to eliminate the possibility of stray current from cell to cell. Segment $C$ of the. figure shows the wiring diagram.

Results of zinc penetration test are given in Table III.9. Comparision of time for zinc penetration through PVA-based and nylon-based separators proved that PVA has better zinc-stopping 
TABLE III. 9

TIME OF ZINC PENETRATION

FOR PVA-BASED SEPARATOR FILMS

\begin{tabular}{|l|c|c|c|}
\hline COMPOSITION & $\begin{array}{c}\text { THICKNESS, } \\
\text { mil }\end{array}$ & $\begin{array}{c}\text { ELECTRICAL } \\
\text { RESISTANCE } \\
\text { m } \Omega \text { in }^{2} / \mathrm{mil}\end{array}$ & $\begin{array}{c}\text { TIME, } \\
\text { HOURS }\end{array}$ \\
\hline PVA + DMU + filler & 2 & 30 & 10.0 \\
PVA + DMU & 1.5 & 25 & 7.5 \\
PVA & 1.5 & 20 & 7.0 \\
ERC Polymer Blend & 1.5 & 85 & 4.0 \\
\hline
\end{tabular}



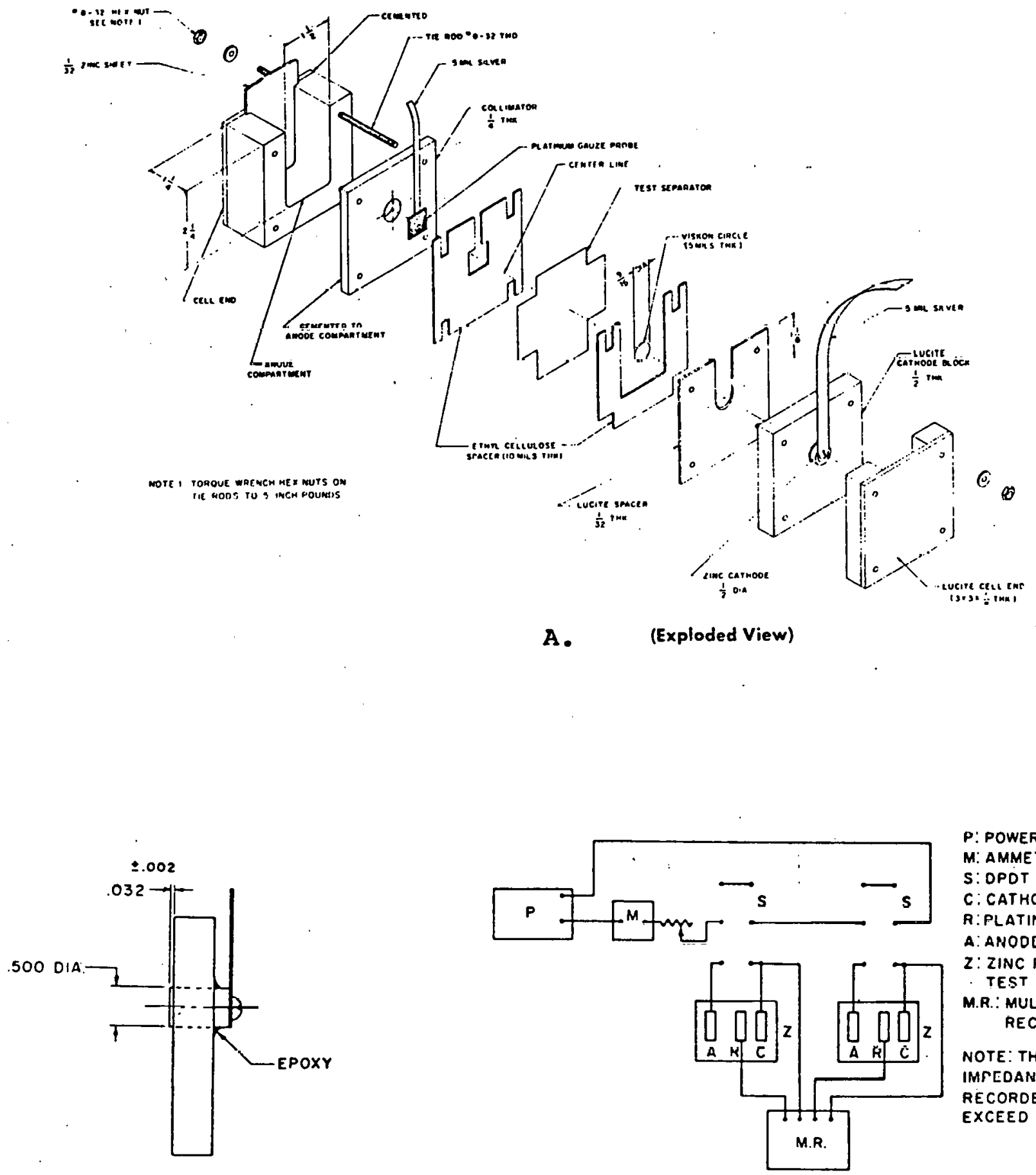

P: POWER SUPPLY

M: AMMETER

S: DPDT SWITCH

C. CATHODE

R:PLATINUM REF.

A: ANOOE

Z: ZINC PENETRATION

TEST CELL M.R.: MULTIPOINT RECOROER

NOTE: THE INPUT IMFEDANCE OF THE RECOROER SHOULD EXCEED O.5 MEGO.

Side View of Zinc Cathode Plate

B.

C. Wiring Diagram 


\section{ENERGY RESEARCH CORPORATION}

ability.

\subsubsection{The Permeability Mechanism Through PVA Films}

study of the permeability mechanism through PVA films was continued for better understanding of the criteria to develop improved separator materials.

PVA is a hydrophilic polymer and transport of electrolyte through hydrophilic films was the object of extensive study. The theory that transport of electrolytes through hydrophilic polymers is a process of diffusion permeability ${ }^{3}$ has found general recognition. The process of permeability consists of three stages: sorption, diffusion in polymer, and desorption. The basic principle is that the electrolyte should be dissolved in polymer for the process of permeability to occur. Transport of electrolytes can be described by the permeability coefficient P. "

$$
P=D K
$$

Where:

$$
\begin{aligned}
D= & \text { diffusion coefficient } \\
K= & \text { distribution constant, which determines concen- } \\
& \text { tration of electrolyte in the polymer }
\end{aligned}
$$

Solubility of salts in hydrophilic polymers is related to presence of water in the polymer. 5 Therefore concentration and distribution of water in polymer are very important for the permeability process. ${ }^{6}, 7$ Concentration of electrolyte in the polymer becomes equal to concentration of electrolyte in external solution at a high concentration of water in the polymer. ${ }^{5}$ The coefficient of electrolyte diffusion is also a function of concentration of water in the polymer. Theory of free (void) volume was the basis for deducing the following formula, ${ }^{5}$ " 
which correlates the coefficients of electrolyte diffusion in water $\left(D_{O}\right)$ and in the polymer (D).

$$
\log D=\log D_{O}-K\left(\frac{1}{H}-1\right)
$$

Where:

$$
\begin{aligned}
\mathrm{K}= & \text { constant which does not depend on the nature of } \\
& \text { the polymer } \\
\mathrm{H}= & \text { concentration of water in the polymer (v.p.) }
\end{aligned}
$$

Acrnriing to Eq. 2, the diffusion coefficient should monotonically decrease with an increase in the quantity of water in the polymer film.

Variation in the electrical resistance (permeability) of PVA films as a function of exposure time in aqueous electrolyte was studied. Experimental data show a very sharp decrease of electrical resistance during the first three to four days (see Figure III.2). A further four to five months in KOH does not essentially change the electrical resistance of PVA. The results obtained indicate that electrolyte (which had been absorbed for three tc four days), created conditions in PVA for equilibrium permeability. The same effect has been achieved during formation of PVA film from aqueous solution by variation of the temperature or time of drying. Such variation results in a different. quantity of residual solvent (water) in film and different electrical resistance (see Table III.10). These data indicate that electrical rccictanoe of PVA depends on the quantity of residial water in the film: An increase in quantity of water results in a sharp decrease in electrical resistance. This dependence is valid up to the quantity of residual solvent equal to $\sim 6 \%$. A further increase in quantity of water in PVA film does not in- 
TABLE III. 10

CONCENTRATION OF RESIDUAL SOLVENT AND ELECTRICAL RESISTANCE OF PVA FILMS

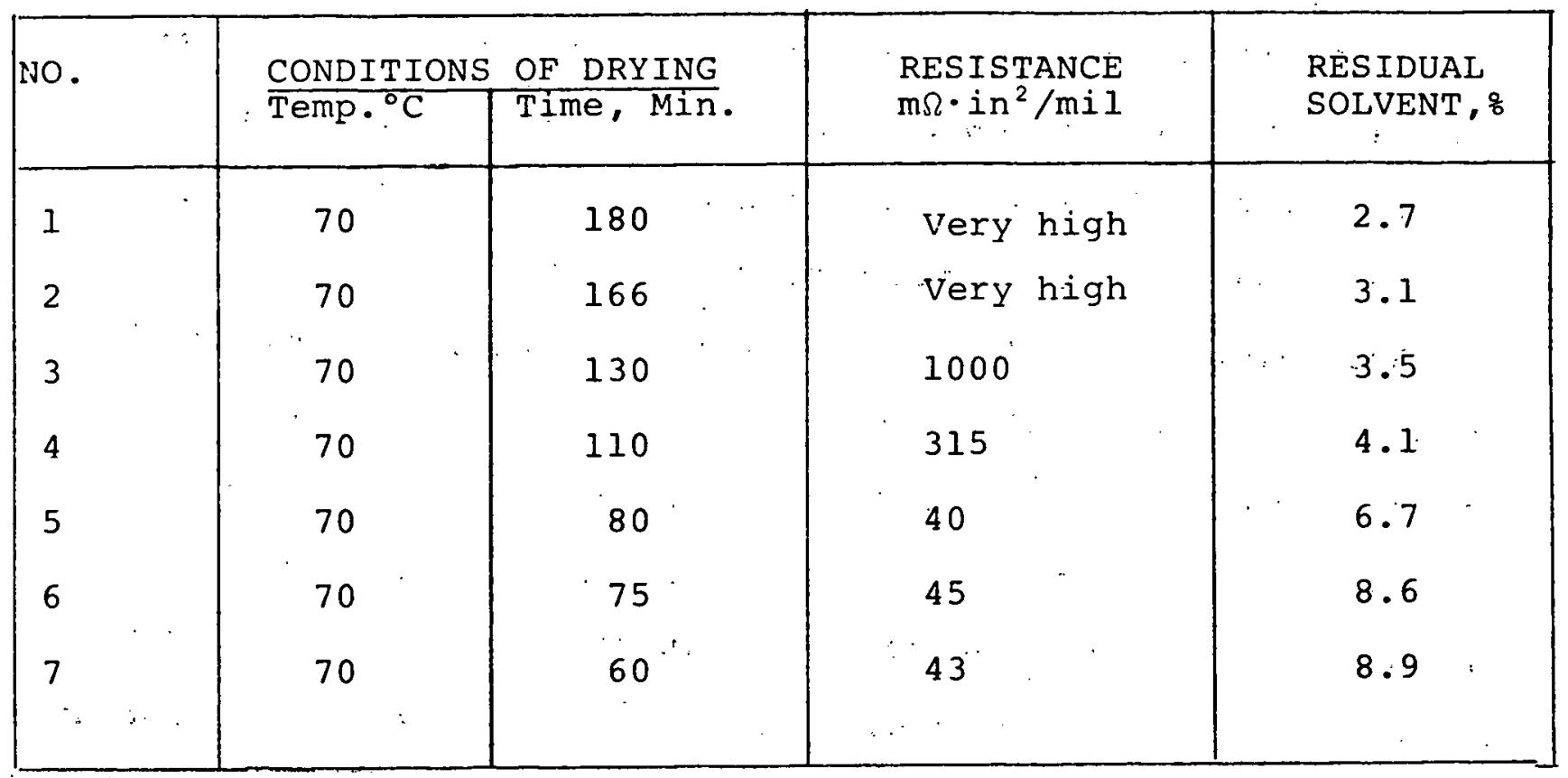

Page No. 93 
fluence the electrical resistance (permeability) which reaches an equilibrium value for this film.

After these experiments, dry film (with approximately 1 to $1.5 \%$ residual water) and wet film (with more than $6 \%$ residual water) were tested for 10 days in $\mathrm{KOH}$ (see Table III.11). Variation in value of electrical resistance during the first ten days of aging in $\mathrm{KOH}$ has the same character as shown in Fiqure III.2. Electrical resistance of wet film ( $6 \%$ water) does not change during this period.

According to the data, dry. PVA film absorbs aqueous $K O H$ solution: Presence of water in PVA creates the conditions for higher permeability of the film to ionic flow. This results in a decrease of electrical resistance during the first days up to a certain equilibrium level, which does not change over the next five to six months. Therefore low electrical resistance of the PVA films can be achieved by employing two methods: 1) preliminàry exposure of PVA film in aqueous elcctrolyte for three to four days, and 2) production of wet PVA films containing more than $6 \%$ residual water.

Production parameters for PVA films with a definite quantity of residual water can be calculated by the following equation:

$$
t=B \exp \left[\frac{\Omega_{0}-a \log c}{R}\left(\frac{i}{T}-\frac{1}{T}\right)\right]
$$

Where; $t=$ time of film formation

$Q_{0}=$ activation energy of solvent diffusion

$\mathrm{B}=$ constant

$\alpha=$ constant of polymer-solvent system

$\mathrm{T}=$ temperature of film formation, $\mathrm{K}$

$\mathrm{T}_{\mathrm{p}}=$ constant of polymer-solvent system.

$\mathrm{C}=$ concentration of the residual solvent in film

Page No. 94 
TABLE III. 11

VARIATION IN ELECTRICAL RESISTANCE OF PVA FILMS CONTAINING DIFFERENT QUANTITIES OF RESIDUAL SOLVENT

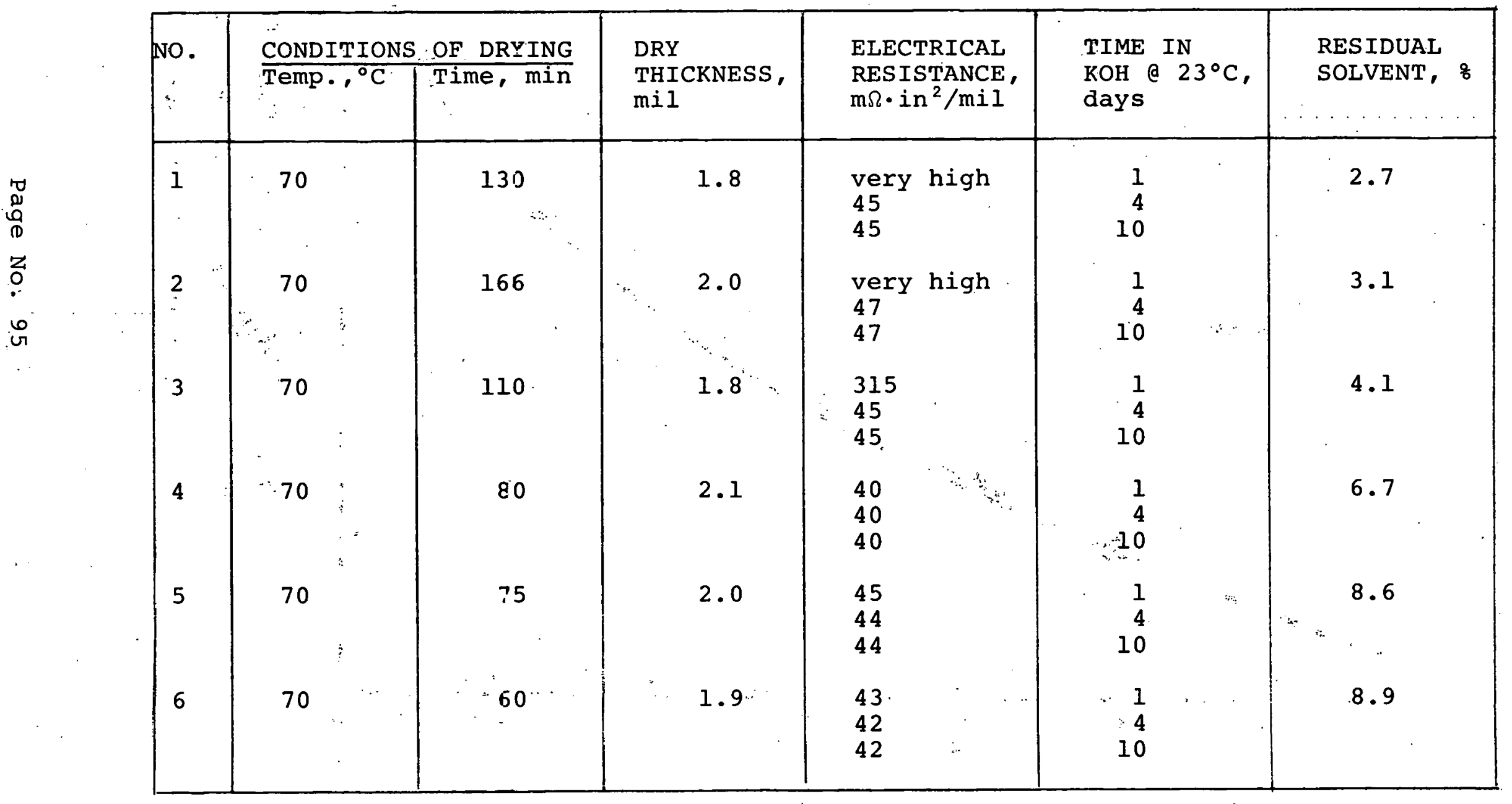




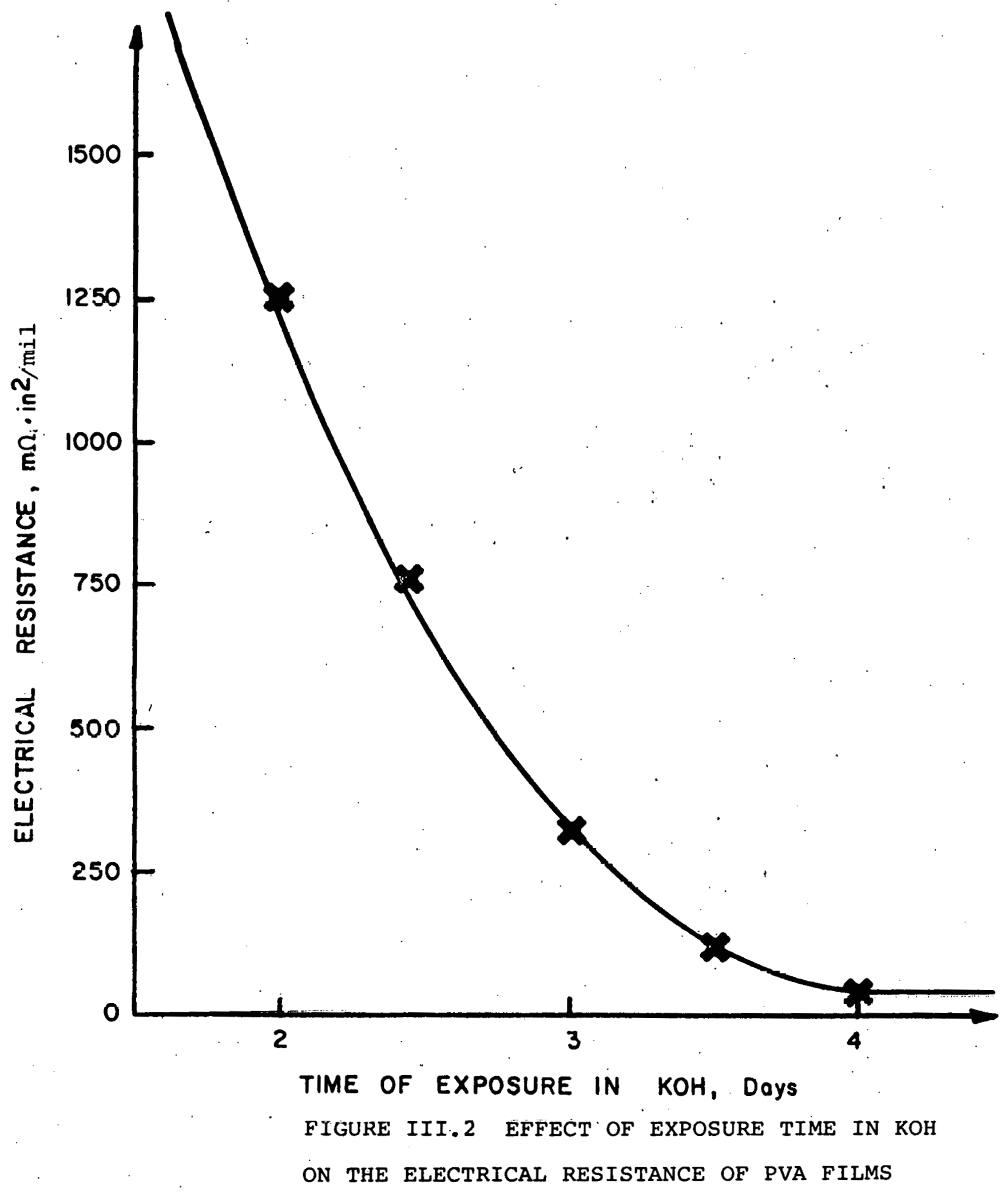

Page No. 96 


$$
R=\text { gas constant }
$$

Constants of Eq. 3 for PVA based systems tested are presented in Table III.12.

Eq. 3 can be used up to about $20 \%$ residual solvent in the film for all systems tested. Existence of the concentration limit is related to a change of the diffusion mechanism at the region of about $20 \%$ solvent in a polymer. Eq. 3 describes the last stage of film formation when solvent bonded with the polymer takes part in the diffusion process. Approximately $20 \%$ of the solvent is necessary to localize intermolecular interaction in the polymer. ${ }^{10}$ So if the concentration of the solvent in the polymer is higher than $20 \%$, transference of the solvent to the evaporation surface is carried out by self-diffusion of the solvent. The process of self-diffusion proceeds with an activation enery, which is essentially lower than the value of $Q_{0}$ in Eq. 3 and does not depend on concentration of the solvent in the polymer. 11

The permeability mechanism of aqueous electrolytes through the PVA membrane has the same solvent-polymer character. Therefore, by analogy with the desorption process, there are two periods of diffusion transfer which should occur during electrolyte permeability through the hydrophilic polymers:

1) Non-equilibrium permeability which is controlled by diffusion of water bonded with the polymer. Transport of the electrolyte is realized by formation and breakdown of intermolecular bonds between the polymer and solvent. Activation energy of diffusion depends on quantity of water absorbed in the polymer according to the following equation:

Where

$$
Q=Q_{0}-\alpha \log c
$$

$$
\begin{gathered}
Q=\text { effective activation energy of diffusion } \\
\text { Page No. } 97
\end{gathered}
$$


TABLE III. 12

CONSTAETS OF EQUATION (3) FOR PVA-BASED SYSTEMS

\begin{tabular}{|c|c|c|c|c|c|c|}
\hline SYSTEM & $Q_{0}, \frac{\mathrm{Kcal}}{\mathrm{mol}}$ & $\alpha \cdot \frac{\mathrm{Kcal}}{\operatorname{moI}}$ & $\mathrm{T}_{\mathrm{p}},{ }^{\circ} \mathrm{C}$ & B, min & $c_{1 i m, 8}$ & $\begin{array}{l}\text { Correlation } \\
\text { Coefficient }\end{array}$ \\
\hline $\begin{array}{l}\text { PVA (88-398 hydrolyzed) } \\
+ \text { Water }\end{array}$ & 32.0 & 23.45 & 100 & 17.2 & 23 & 0.978799 \\
\hline $\begin{array}{l}\text { PVA }(88-898 \text { hydrolyzed }) \\
+ \text { Water }\end{array}$ & 32.5 & 23.87 & 98 & 19.0 & 23 & 0.978072 \\
\hline $\begin{array}{l}\text { PVA }(88-898 \text { hydrolyzed }) \\
+ \text { water }+ \text { Methanol }(75: 25) \\
\left(T<65^{\circ} \mathrm{C}\right)\end{array}$ & $\quad 31.6$ & 23.21 & 82 & 24 & 23 & 0.986987 \\
\hline $\begin{array}{l}\text { Pva }(88-898 \text { hydrolyzed }) \\
+ \text { Water }+ \text { Methanol }(75: 25) \\
\left(65^{\circ} \mathrm{C}<\mathrm{T}<100^{\circ} \mathrm{C}\right)\end{array}$ & 14.9 & 10.94 & 100 & 24 & 23 & 0.987168 \\
\hline $\begin{array}{l}\text { PVA }(99-100 \% \text { hydrolyzed }) \\
+ \text { Water }\end{array}$ & 37 & 27.21 & 100 & 15.9 & 23 & 0.993685 \\
\hline $\begin{array}{l}\text { PVA }(99-1008 \text { hydrolyzed) } \\
+ \text { Water + Boric Acid (IO\&) }\end{array}$ & 37.3 & 27.39 & 98 & 3.3 & 23 & 0.981097 \\
\hline $\begin{array}{l}\text { PVA }(99-1008 \text { hydrolyzed) } \\
+ \text { water }+ \text { Methanol }(75: 25) \\
\left.\text { (T } 565^{\circ} \mathrm{C}\right)\end{array}$ & 36.5 & 26.8 & 82 & 27 & 23 & 0.987345 \\
\hline $\begin{array}{l}\text { PVA } 199-1008 \text { hydro-yzed) } \\
+ \text { watez }+ \text { Methano }(75: 25) \\
65^{\circ} \mathrm{C}<\mathrm{T}<100^{\circ} \mathrm{C}\end{array}$ & 18.0 & 13.22 & 100 & $2 \pi$ & 23 & 0.952007 \\
\hline
\end{tabular}


While increasing the quantity of absorbed water (decreasing the effective activation energy of diffusion), the intermolecular interaction in polymer weakens and the rate of diffusion increases. This process will continue until the local concentrations of water reach the level when the intermolecular interaction is neutralized in certain amorphous regions, and

2) The process of diffusion transport changes near this concentration from diffusion of molecules bonded with a polymer to self-diffusion of the solvent which is not attached to the polymer. Self-diffusion has low activation energy which does not depend essentially on the concentration of water in polymer. Non-equilibrium permeability transforms into equilibrium permeability, which can be described by Fick's laws. The rate of diffusion is not dependent on quantity of absorbed or residual water if this quantity is higher than the quantity necessary to reach the equilibrium permeability (self-diffusion) level.

The amount of water which should be obtained in the polymer to achieve the self-diffusion level is different for the process of film formation and for electrolyte diffusion. Such difference is related to the fact that aqueous electrolyte is not a solvent for PVA and, therefore, the diffusion process occurs mostly through the channels in amorphous regions where the local concentration of water is higher than in the bulk film.

Dependence of electrolyte permeability on quantity of residual water in the film is not an individual property of FVA. Other polymers which absorb water or can be dissolved in water or solvent mixtures containing water exhibit similar properties. Some polymers do not have the ability to absorb water from aqueous electrolyte solutions. Therefore another way to increase their permeability is to leave a certain quantity of residual water in film during production of these membranes from the solution containing water. For example, polyethylene oxide or polyamides do not absorb or lose water in an electrolyte environment and permeability properties formed during the production process are fixed in the membrane. Consequently, it is possible to regulate permeability 
properties of plastic films for aqueous solutions simply by changing the quantity of residual water in film.

Correctness of Eq. 3 for different polymer-solvent systems ${ }^{9}$ shows that permeability of any polymer membrane for any solution can be increased if the polymer membrane contains a certain quantity of solvent which is employed in the solution. Solvents present in the film other than those used in solution intended for permeation do not essentially influence the rate of permeability.

\subsubsection{Failure Mode Observation of Ce11s Containiriğ PVA Based} Separator Films

As indicated in Table III.4, the shape change of the $\mathrm{Zn}$ electrode depends on degree of swelling of the separator film. Addition of a filler or supporting layer resulted in considerable reduction of degree of swelling and shape change in the $\mathrm{zn}$ electrode. But cycle life of the cells did not increase because zinc dendrites grew through the separator.

Work carried out with PVA separators thus far allows the conclusion that PVA material has high stopping ability for zinc dendrites because it works as a selective membrane. Increasing the chemical stability of PVA by crosslinking permitted an increase in the cycle life of the cell by 1.5 to 2 times but did not solve the problem of shape change of the zinc electrode. Decrease of swelling and wrinkling of PVA separator film leads to decreasing shape change of the neyative electrode but did not increase cycle life of the cell.

Crosslinking increases mechanical strength and chemical stability of the PVA based films which results in reducing the 
danger of dendritic growth through the separator. However crosslinking could not reduce shape change of the negative electrode and, therefore, does not substantially increase cycle life of the cell: Cycle life of the cells with both modes of failure is almost identical. Acceleration of the shape change process in cells containing PVA based separators can probably be explained by specific properties of the PVA separator as a selective membrane which creates high concentration gradients and causes reduction and precipitation of metallic zinc and zinc oxide from the separator bag and zinc electrode. Consequently crosslinking of PVA increases the probability of cell failure by the shape change mode and reduces the hazard of zinc penetration but does not result in a substantial increase in cycle life of the cells. These results necessitate that ERC. look for a combination microporous/membrane type material combined in one separator system.

\subsection{IMPROVED COMPOSITION FOR POLYMER-BLEND SEPARATOR FIIMS}

Chemically stable polymer-blend compositions with low electrical resistance were developed during the first year of work under the program. Use of these polymer-blend separators in Ni-zn cells, resulted in reduction of shape change of the $\mathrm{zn}$ electrode but did not result in an increase in cycle life of the cells up to the required level. Therefore, attempts to improve the composition were continued during the second year of work. 


\subsubsection{Evaluation of Polymer-Blend Films as a Separator Material}

Continuing work this period included measurement of the stability of electrical resistance and appearance of the films as a function of exposure time in $\mathrm{KOH} \mathrm{(Table \cdot III.13).} \mathrm{According}$ to results obtained, electric resistance and appearance of the film did not change during a six month exposure in $45 \% \mathrm{KOH}$ solution.

Tensile strength of polymer-blend films was measured for different compositions of solutions. The results presented in Table III.14 indicate that strength and elasticity of the polymerblend films are in the range which could be considered acceptable for separator materials in $\mathrm{Ni}-\mathrm{Zn}$ cells. Such a conclusion is based on stability in $\mathrm{KOH}$ environment and on electrical tests of the material in a number of cells. Degradation of polymer-blend films was not observed in cells which have been taken apart after sysling.

Results nf the zinr penetration test. given in Table III.15 show that variation in the zinc penetration time of several samples taken from one piece of film is between one and six hours. Such large differences indicate non-uniformity of the properties in films made by a doctor blade. Comparison of zinc penetration time in PVA-based and polymer-blend separators proved that PVA has better zinc-stopping ability. Therefore, employment of polymer-blend and PVA-based materials together in a separator system results in reducing shape change (by the polymer-blend separator component) and increasing zincstopping ability (by the PVA coating). 
TABLE III. 13

ELECTRICAL RESISTANCE OF NYLON-BASED FILMS

DURING EXTENDED EXPOSURE TIME IN KOH

\begin{tabular}{|c|c|c|c|c|c|c|c|c|c|c|c|}
\hline \multirow{2}{*}{\multicolumn{3}{|c|}{ COMPOSITION }} & \multirow{2}{*}{$\underset{\text { mil }}{\text { THICKNES5, }}$} & \multicolumn{8}{|c|}{ RESISTANCE, $\mathrm{m} \Omega^{\circ} \mathrm{in}^{2} / \mathrm{mil}^{2}$} \\
\hline & & & & INITIAL & AFTER 2 & Mos. & AFTER 3 & 3 mos. & AFTER 4 MOS. & AFTER 5 MOS. & AFTER 6 MOS. \\
\hline $\begin{array}{l}\mathrm{Pa}+\mathrm{Po}+ \\
30: 10:\end{array}$ & $\begin{array}{l}\text { vic + } \mathrm{Ce} \\
6: \quad 4:\end{array}$ & & 2.5 & 25 & 30 & & 32 & & 20 & 25 & 30 \\
\hline $\begin{array}{l}\mathrm{Pa}+\mathrm{SiO}_{2} \\
35: \quad 6:\end{array}$ & $\begin{array}{c}+\mathrm{CeO}_{2} \\
4:\end{array}$ & $\begin{array}{c}+v i c+\text { po } \\
6: \quad 3:\end{array}$ & 3 & 185 & 175 & & 190 & & 170 & 180 & 160 \\
\hline $\begin{array}{l}\mathrm{Pa}+\mathrm{SiO}_{2} \\
35: \quad 6:\end{array}$ & $\begin{array}{c}+\mathrm{CeO}_{2} \\
\quad 4:\end{array}$ & $\begin{array}{c}+v_{i c}+\text { Po } \\
6: \quad 3:\end{array}$ & 3 & 15 & 25 & & 30 & & 20 & 25 & 20 \\
\hline $\begin{array}{l}\mathrm{Pa}+\mathrm{SiO}_{2} \\
35: \quad 6:\end{array}$ & $\begin{array}{c}+\mathrm{CeO}_{2} \\
4:\end{array}$ & $\begin{array}{c}+V i c+P o \\
6: \quad 4:\end{array}$ & .3 .5 & 85 & 40 & & 50 & & 60 & 70 & 55 \\
\hline $\begin{array}{l}\mathrm{Pa}+\mathrm{Po}+ \\
30: \quad 10:\end{array}$ & $\begin{array}{l}\text { Vic } \\
\text { 3: }\end{array}$ & - & 2.2 & 20 & 25 & & 30 & & 35 & 20 & 25 \\
\hline $\begin{array}{l}\mathrm{Fa}+\mathrm{PO}+ \\
30: 10:\end{array}$ & $\begin{array}{l}\text { vic + cec } \\
6: \quad 4:\end{array}$ & $\begin{array}{l}\mathrm{E}_{2} \div \mathrm{TEA} \\
=2:\end{array}$ & 3.5 & 45 & 50 & & 40 & & 45 & 35 & 40 \\
\hline
\end{tabular}


TABLE III. 14

TENSILE STRENGTH OF POLYMER-BLEND FILMS

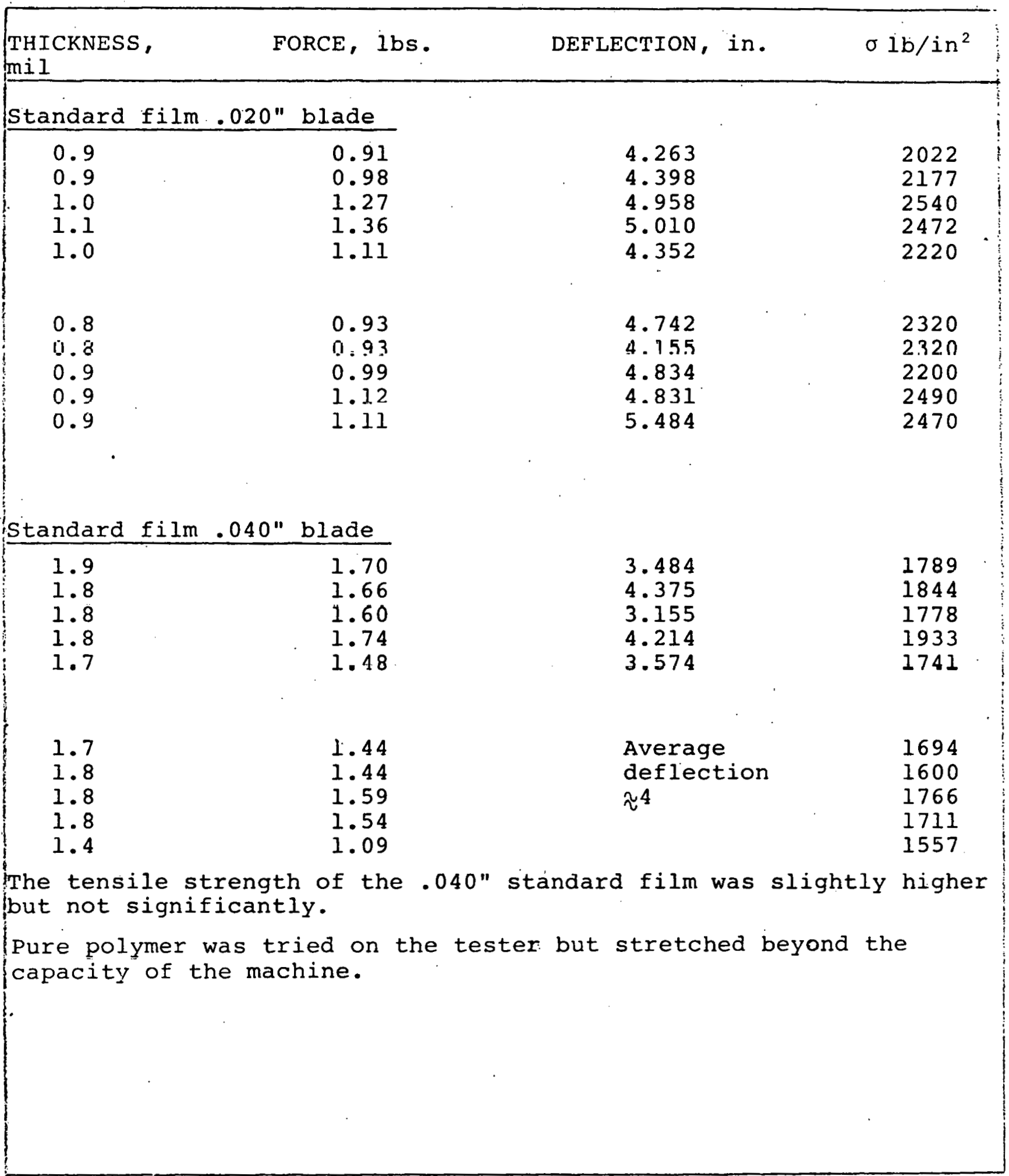

Page No. 104 
TABLE III.15

COMPARISON OF ZINC PENETRATION TIME FOR POLYMER-BLEND AND PVA-BASED SEPARATOR FILMS

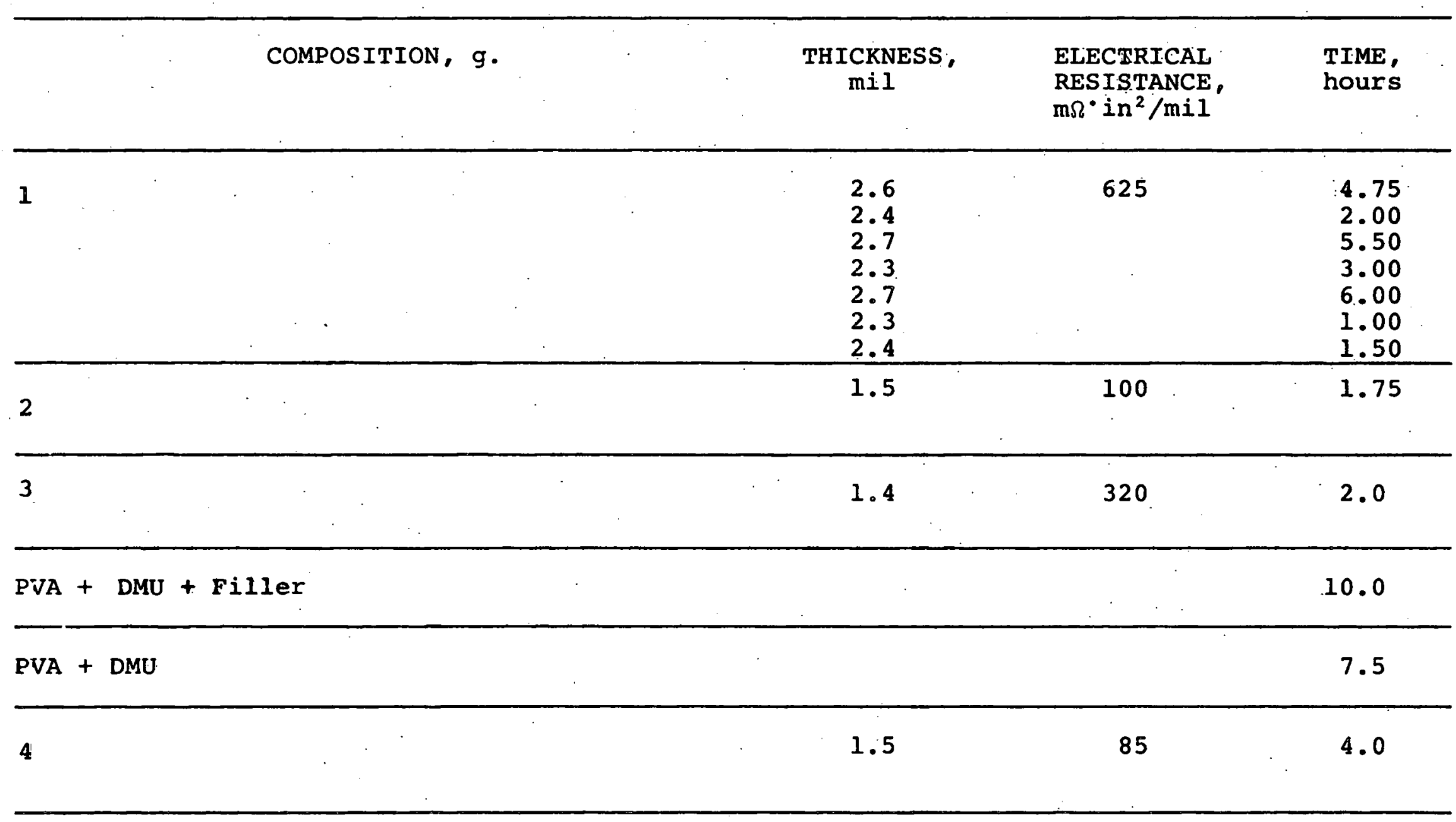


An attempt was made to find a correlation among various methods of testing and the properties of separator materials. Three methods were evaluated:

- The rate of $\mathrm{OH}^{-}$ion diffusion (see Table III.16)

- Electrical resistance, and,

- Time of zinc penetration through the separator.

Polymer-blend films were produced with different

resistances, An $\mathrm{OH}^{-}$diffusion test was conducted for the same films, then zinc penetration time through the films was measured. The data obtained are presented in Table III.17 and in Figure III.3. According to the results obtaired, there is some correlation between electrical resistance of the film and its permeability to $\mathrm{OH}^{-}$. However, the data are not linear which would be expected as a result of the similarity of test conditions.

Time of zinc penetration does not correlate with electrical resistance of the film, or the rate of $\mathrm{OH}^{-}$diffusion. This can be explained by the difference in sensitivity of the tests: Electrical resistance and rate of diffusion relate to average porosity of the sample while the time of zinc penetration depends on the largest pore of the sample. Therefore, if different films have different pore size distributions, variations in diffusion rate and electrical resistance will result. The same films can have the same largest pore diameter and time of zinc penetration does not vary (see Table III.i7). 


\section{TABLE III. 16}

ELECTROLYTE DIFFUSION RATE MEASUREMENTS

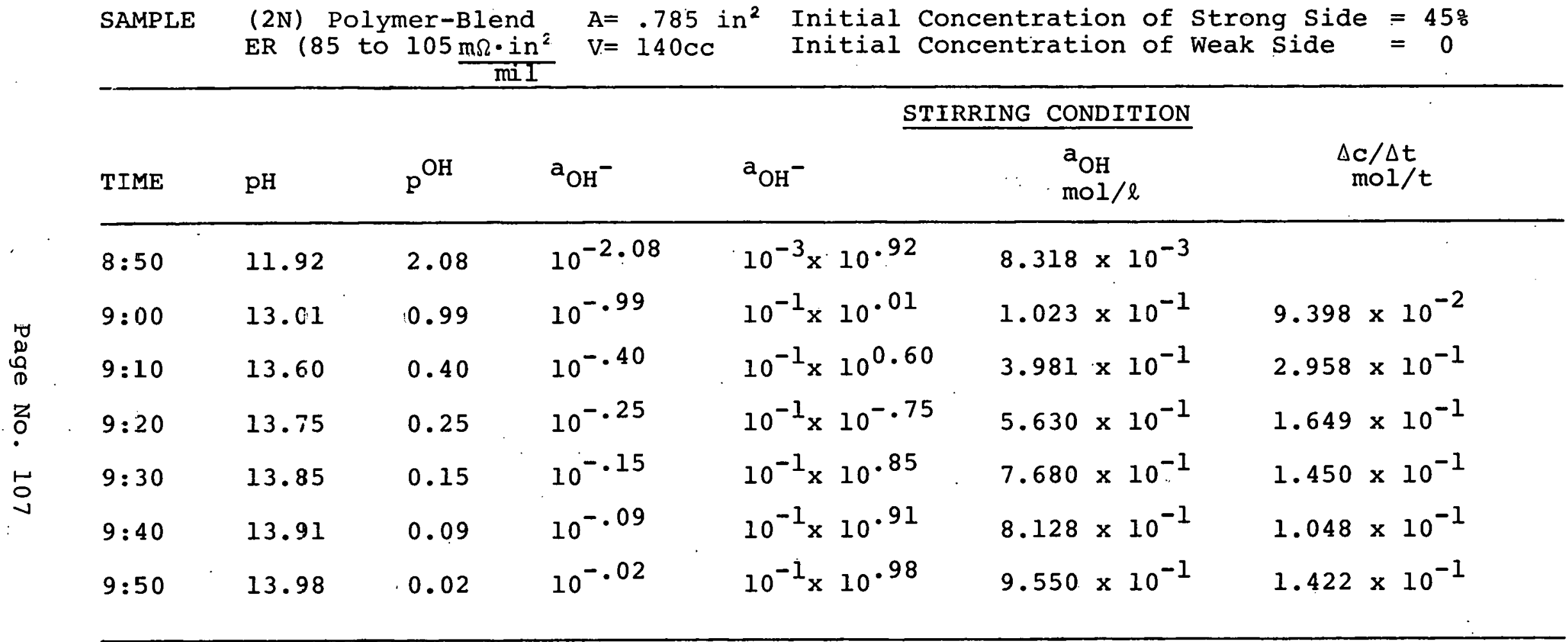

$\frac{\Delta \mathrm{M}}{\mathrm{A} \Delta \mathrm{t}}=\frac{\Delta \mathrm{c}}{\Delta \mathrm{t}} \times \frac{\mathrm{V}}{\mathrm{A}}=\frac{.140 \times 1.3208 \times 10^{-1}}{.785 \times 10}=2.3555 \times 10^{3} \mathrm{~mol} / \mathrm{min}^{\mathrm{in}} \mathrm{in}^{2}$ 
TABLE III. 17

RESULTS OF TESTING DIFFERENT POLYMER-BLEND FILMS

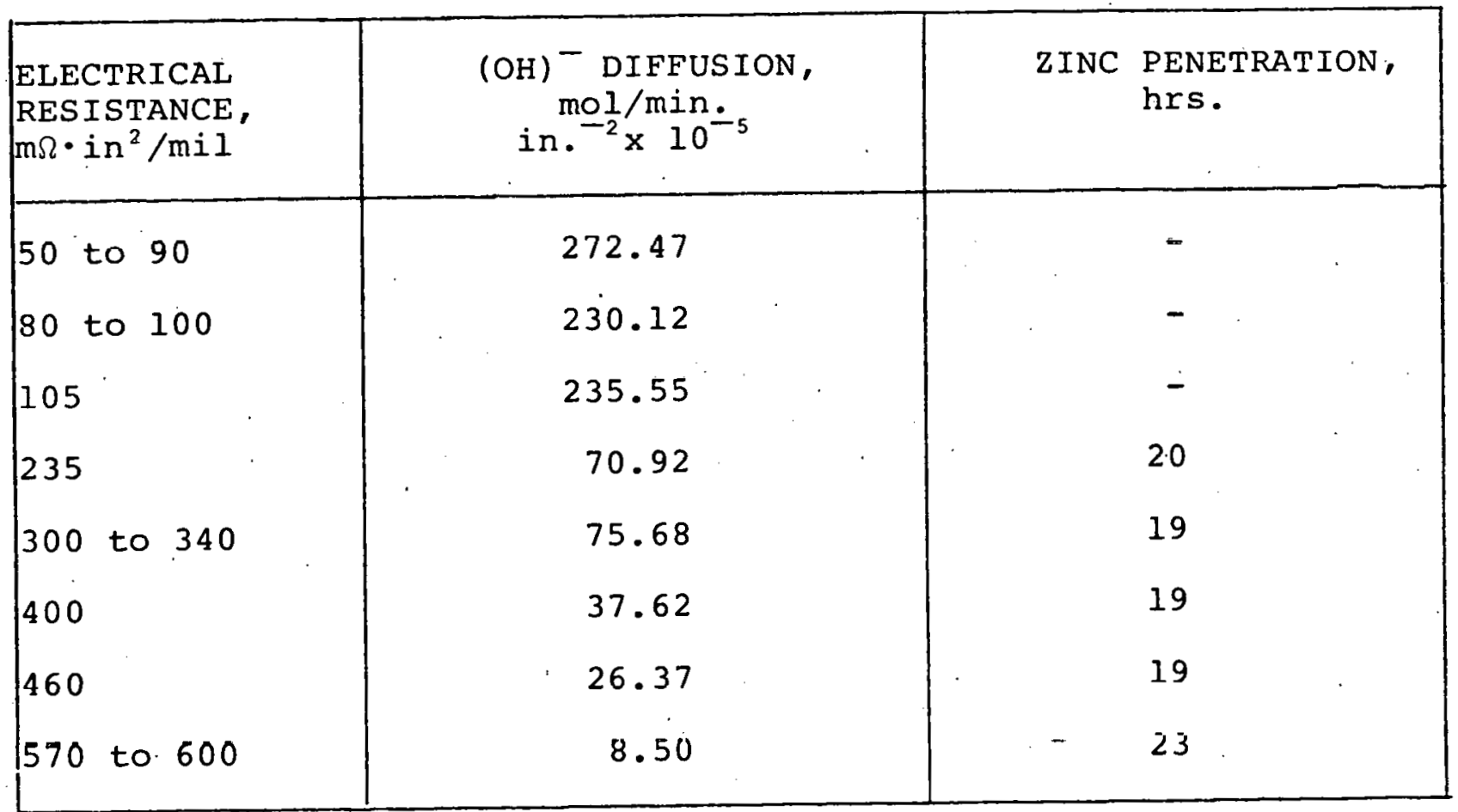




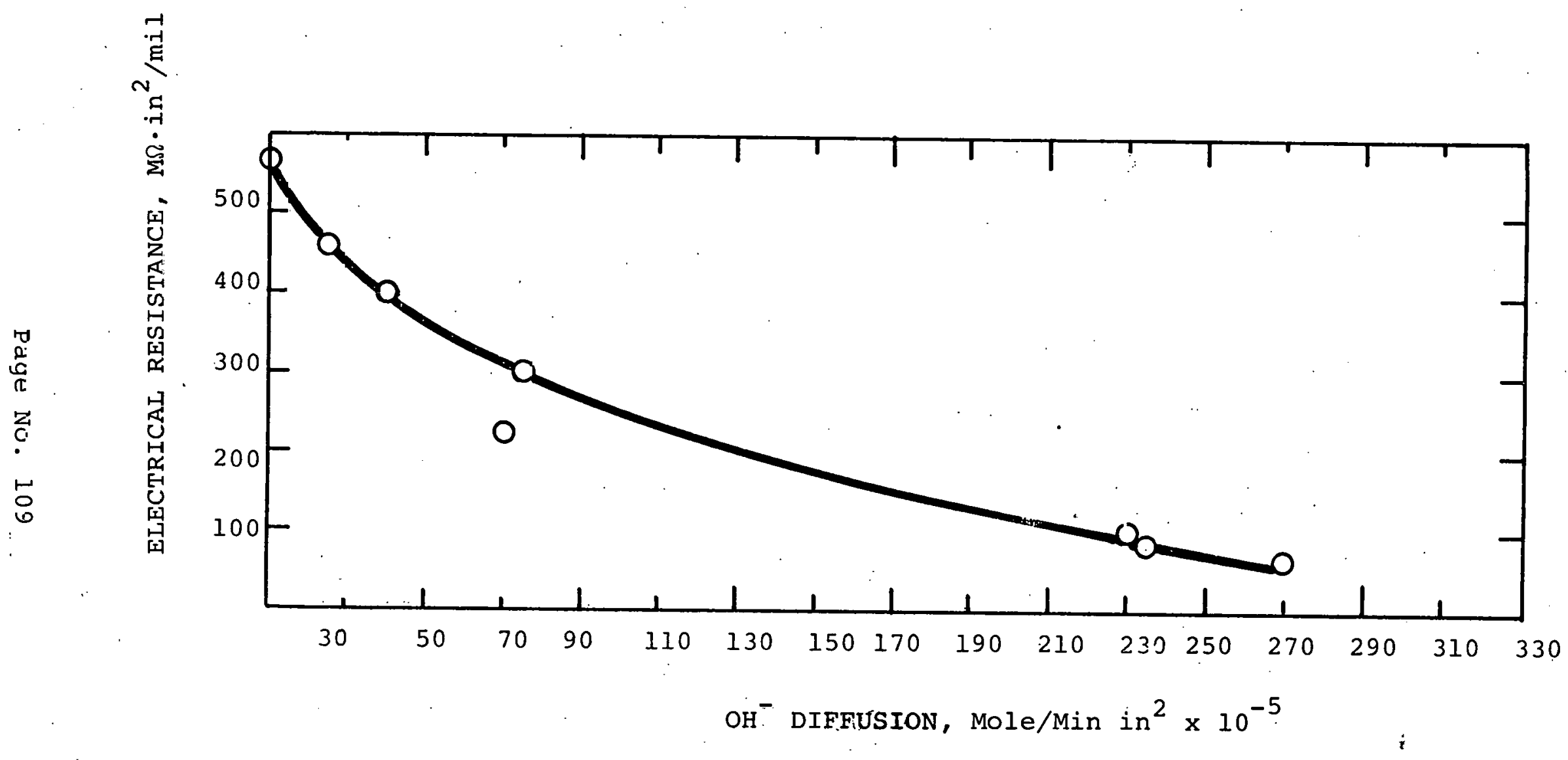

FIGURE III.3 ELECTRICAL RESISTANCE VS $\mathrm{OH}^{-}$DIFFUSION FOR (2N) POLYMER-BLEND 
Pore size distribution in the polymer-blend film was measured by mercury-porosimeter and initial results are given in Figure III. 4 and Table III.18.

Quaritity of residual solvent in the separator film also has an influence on the properties of the material and, therefore, parameters of polymer-blend film formation were determined. Results of measuring the quantity of residual solvent in films formed under differenl conditions are given in Table III.19. After completing this part of the work, the properties of polymer-blend films can be compared under similar conditions (the same quantity of residual solvent in film). 2.2.2 Testing of cells containing one Layer of Polymer-Blend

For the purpose of studying the interaction between the zinc electrode and the separator systell, several pilymer-blend separators with different electrical resistances were prepared and Ni-zn cells with one layer of these materials were built and tested. Some of the cells were terminated on cycle test before they failed in order to learn how fiailure progresses during cycling.

Test Conditions:

$\begin{array}{ll}\text { Charge } & 3 \text { hours at } 1.2 \mathrm{~A} \\ \text { Discharge } & 1 \text { hour at } 3 \mathrm{~A} \\ \text { Overcharge } & 20 \% \\ \text { Depth } & 75 \%\end{array}$




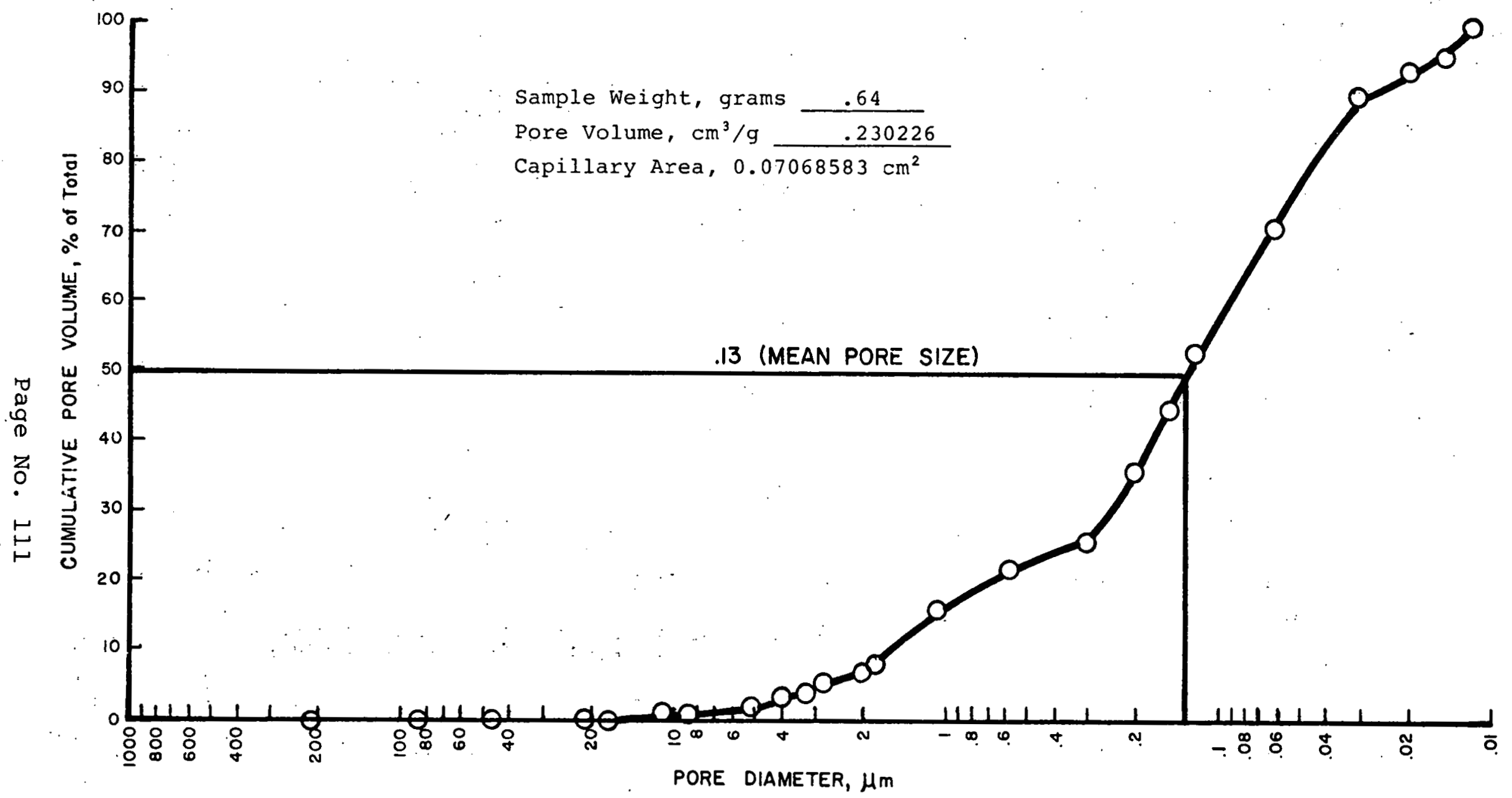

FIGURE III.4 PORE SIZE DISTRIBUTION OF POLYMER-BLEND FILM 
TABLE III. 18

CUMULATIVE .PORE SIZE DISTRIBUTION OF POLYMER-BLEND FILM

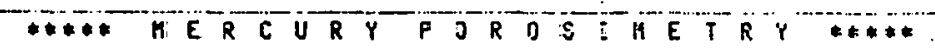

-..-- CUKULATIVE PORE SIZE OISTRIBUTIOM-..--

\section{TEST NO.PT-14}

SAHPLE VEICHT, (CRAKST.640

GATE $6 / 8 / 80$

OPERATOR. MICHEEL MOHHERAT

EHGIHEER H. COOIH

PRESSURE (KG/CA2) *OIRIEETER(HICRONS) = 12.46

(COHTACT ANGLE $=130$ OECREES, SURFACE TEHSIOH $=484$ OYHESTCH)

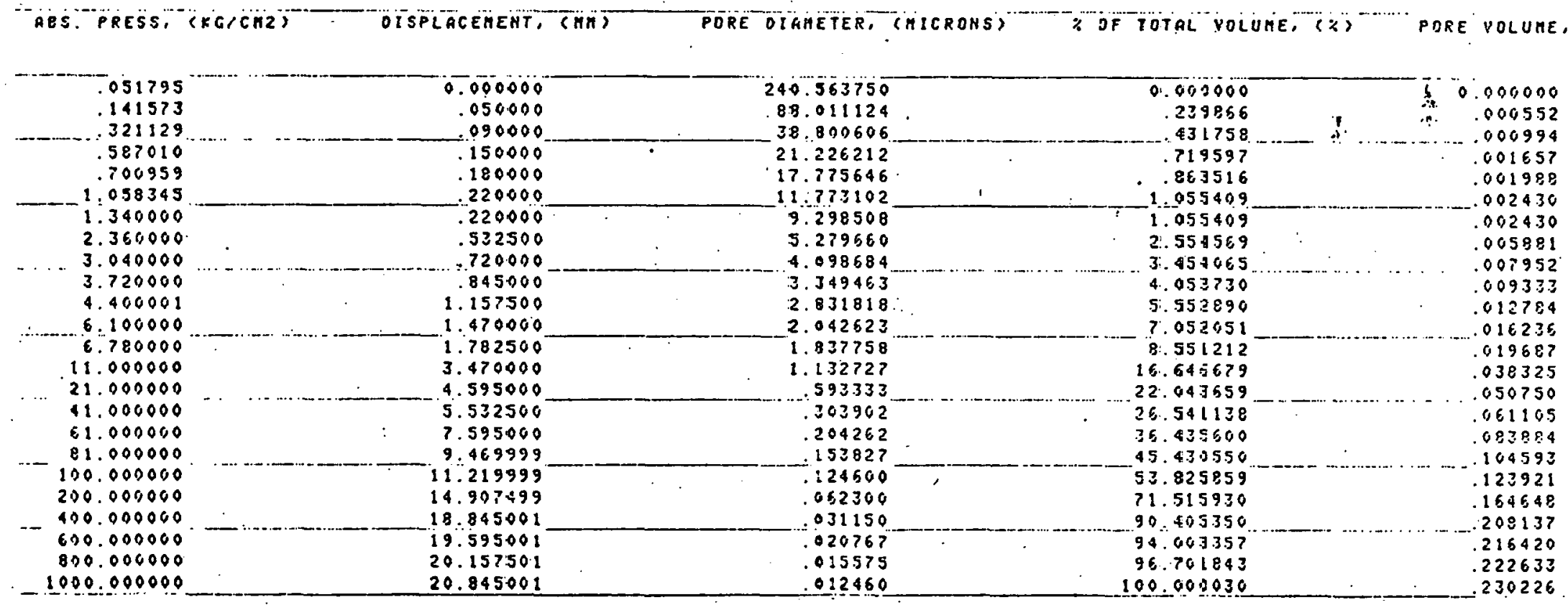


TABLE III. 19

QUANTITY OF RESIDUAL SOLVENT IN POLYMER-BLEND FILMS

(Thickness of the film, $\delta=2.5 \mathrm{mil}$ )

\begin{tabular}{|c|c|c|c|}
\hline No. & $\begin{array}{l}\text { TEMP } . ~ O F \\
\text { FORMATION, }{ }^{\circ} \mathrm{C}\end{array}$ & $\begin{array}{l}\text { TIME } \\
\text { Min. }\end{array}$ & $\begin{array}{c}\text { QUANTITY OF } \\
\text { RESIDUAL SOLVENT, }\end{array}$ \\
\hline $\begin{array}{l}1 \\
2 \\
3 \\
4 \\
5 \\
6 \\
7 \\
8\end{array}$ & $\begin{array}{l}23 \\
23 \\
23 \\
23 \\
23 \\
23 \\
23 \\
23\end{array}$ & $\begin{array}{l}20 \\
35 \\
30 \\
35 \\
40 \\
45 \\
50 \\
55\end{array}$ & $\begin{array}{l}35.57 \\
35.52 \\
27.40 \\
39.64 \\
20.28 \\
21.92 \\
17.13 \\
14.68\end{array}$ \\
\hline $\begin{array}{l}9 \\
10 \\
11 \\
12 \\
13 \\
14 \\
15 \\
16\end{array}$ & $\begin{array}{l}40 \\
40 \\
40 \\
40 \\
40 \\
40 \\
40 \\
40\end{array}$ & $\begin{array}{l}20 \\
25 \\
30 \\
35 \\
40 \\
45 \\
50 \\
55\end{array}$ & $\begin{array}{r}35.14 \\
34.48 \\
29.98 \\
29.26 \\
23.07 \\
18.40 \\
10.11 \\
7.02\end{array}$ \\
\hline $\begin{array}{l}17 \\
18 \\
19 \\
20 \\
21 \\
22 \\
23 \\
24\end{array}$ & $\begin{array}{l}60 \\
60 \\
60 \\
60 \\
60 \\
60 \\
60 \\
60\end{array}$ & $\begin{array}{l}20 \\
25 \\
30 \\
35 \\
40 \\
45 \\
50 \\
55\end{array}$ & $\begin{array}{r}32.80 \\
30.63 \\
25.85 \\
23.65 \\
22.04 \\
17.90 \\
9.35 \\
4.03\end{array}$ \\
\hline
\end{tabular}




$$
\begin{array}{ll}
\text { Discharge Rate } & C / 1.5 \\
\text { Cycle Time } & 4 \text { hours }
\end{array}
$$

The separator and zinc electrode were examined after the cells were disassembled. Results of the tests, given in Table III.20, indicated that different separator materials (PVA and polymer-blend) interact with the zinc electrode in different ways and that the design of the separator system also influences the cyele lifc of the cell. Results obtained demonstrate that cycle life of the cells varied from 11 to 106 cycles for one composition of film. Such variation is a function of electrical resistance and uniformity of components and pore size distribution in the separator. The last factor is probably the most important. By using one layer of low electrical resistance and uniform polymer-blend film, it is possible to achieve more than 100 cycles during accelerated test conditions and a drop of only 758 of initial cell capacity. Moreover, polymer-blend separators are considerably more stable in KOH than crosslinkcd PVA tested under the same conditions.

The second task was to compare the performance of the Celgard K-307 separator material with ERC type polymer-blend separators. Celgard $\mathrm{K}-307$ is cellulose acetate coated Celgard 2400 with a total thickness about $1.5 \mathrm{mil}$. The ooating was applied on both sides of the polypropylene film. Cells with one and two layers of Celgard $k-307$ were prepared and two cells with one layer of polymer-blend separator were tested for comparison. The thickness of the polymer-blend film was about $3 \mathrm{mils}$. These single electrode cells were all tested under the same conditions. The results, presented in Table III.21 (cells 1 through 4), indicate 
INFLUENCE OF SEPARATOR DESIGN ON THE ZINC ELECTRODE AND ON CYCLE LIFE OF THE CELI

\section{Electrode}

Type No.

2 Full sintered $N$

1 Full zinc

2no -938

TFE - 28

\section{Electrode Theo. \\ Charge/ \\ Disch.}

Szie/In.

H-3-7/8" $\pm 1 / 16$

in-2-7/8" $\pm 1 / 1$

$\mathrm{T}-.007 " \pm .002$

$14.4 \mathrm{Ah}$

$2.5 \mathrm{~A} \times 1 \mathrm{hr}$.

120

Failure

Cap. (Ah) Resistance Discharge Ratio,

26

pinlioles in film.

\section{Comments}

Film does not swcll.

2 ine electrode does not change shape. Separator is clcar. No zinc out of separator.

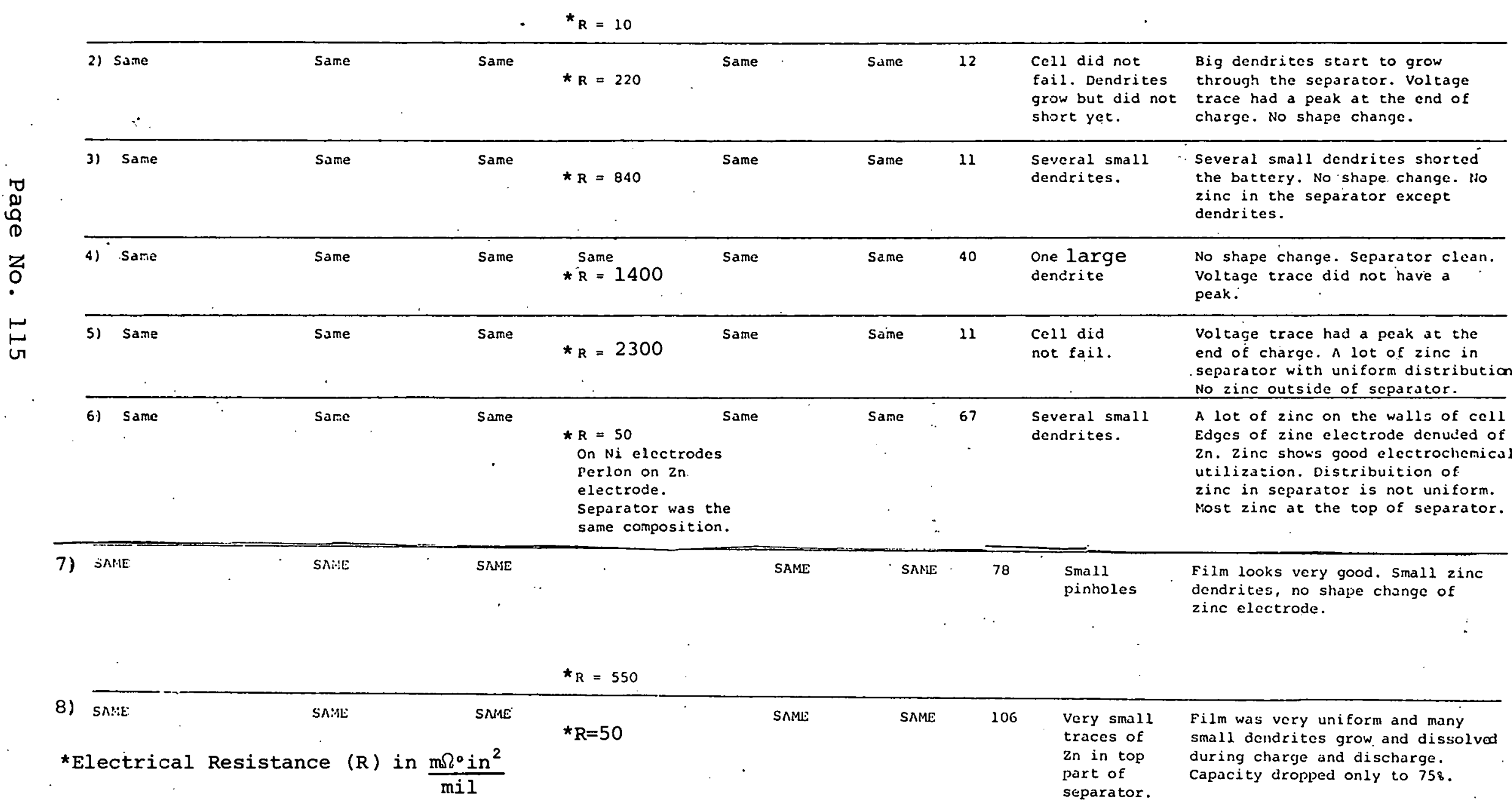


that the cells with the Celgard $\mathrm{K}-307$ separator lasted 120 cycles regardless of whether one or two layers of the film were employed. The failure mode was shape change of the zinc electrode for both cells. The cells did not short and a lot of zinc particles were outside the separator bag. Cells with one layer of polymer-blend separator film, cycled 132 and 138 times, also failed as a result of shape change. The cells did not short and all zinc was inside the separator baqs. Comparieon of cell performance shows that cycle life and failure mode are very similar for cells with one layer of polymer-blend film and with one or two layers of composite material like celgard $\mathrm{K}-307$.

The dependence of cell capacity and the end of discharge voltage on number of cycles is presented in Figure III.5. Comparison of the curves related to Celgard $\mathrm{K}-307$ and polymer-blend separators shows that capacity of the cells with Celgard $\mathrm{K}-307$ starts to decline after 80 cycles and drops very sharply. Cells with polymer-blend separators begin to decline in capacity after 60 cycles but the capacity decline is much slower and cells worked a little longer until $60 \%$ of nominal capacity was reached.

As a result of this work, a polymer-blend composition for separators is being developed for further use in Ni-zn batteries. The film combines properties of selective and microporous membranes and, therefore, cells, with one layer of this separator could work more than 100 cycles. Such results essentially exceed cycle life of cells with any commercially available separator material under the same testing conditions. However, technology of production has not been perfected yet and uniformity of the properties must be improved before development of a reliable 
COMPARISON OF K-307 AND POLYMER-BLEND SEPARATORS

THEORETICAL ZINC CAPACITY $(\mathrm{AH})=14.4 \mathrm{~A}$

ELECTRODE SIZE: $\mathrm{H}-3-7 / 8 " \pm 1 / 16 "$

DISCHARGE $=2.5 \mathrm{~A} \times 1 \mathrm{hr}$.

$W-a-7 / 8^{\prime \prime} \pm 1 / 16^{\prime \prime}$

CHARGE/DISCHARGE RATIO $(\%)=120 \%$

$T-.07 " \pm .002^{\prime \prime}$

\begin{tabular}{|c|c|c|c|c|}
\hline $\begin{array}{l}\text { ELECTRODE } \\
\text { TYPE \& NO. }\end{array}$ & $\begin{array}{l}\text { SEPARATOR } \\
\text { CONFIGURATION }\end{array}$ & CYCLE & $\begin{array}{l}\text { FAILURE } \\
\text { MODE }\end{array}$ & COMMENTS \\
\hline 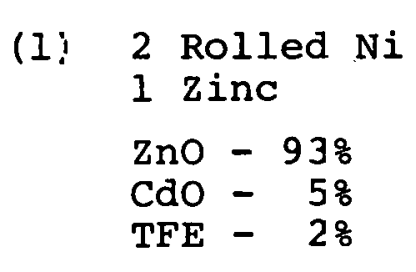 & $\begin{array}{l}\text { One layer of } \mathrm{k}-307 \\
\text { on negative plate }\end{array}$ & 120 & Shape change & $\begin{array}{l}\text { Separator looks good. } \\
\text { There were no pinholes } \\
\text { Separator was some- } \\
\text { what brittle and there } \\
\text { was shape change in } \\
\text { zinc plate. }\end{array}$ \\
\hline
\end{tabular}

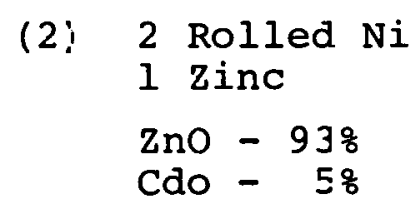

4

Two layers of $\mathrm{K}-307$

on negative plate and

120

Pellon on the plates

\section{Shape change}

Separator looks somewh brittle but still good There was shape change and too much zinc goes through separator.

$(3 i)$
2 Rolled Ni
1 Zinc
Zno - $93 \%$
Cdo $-5 \%$
TFE $-2 \%$

(4) 2 Rolled $\mathrm{Ni}$

1 zinc

One layer of (2N) polymer-blend 138

Zno - 938

Cdo - 58

TFE - $2 \%$
One layer of (2N) polymer-blend 132 on negative plate. Only

Pellon on the plates.

\section{on negative plate}

Shape change Separator looks good. There was no zinc dendrite coat on the sepa rator or in cell. cel dried because of shape change.
Shape change Cell was too tight. N electrode swelled and compressed the zinc pl $\mathrm{Zinc}$ was on Pellon absorbers. 


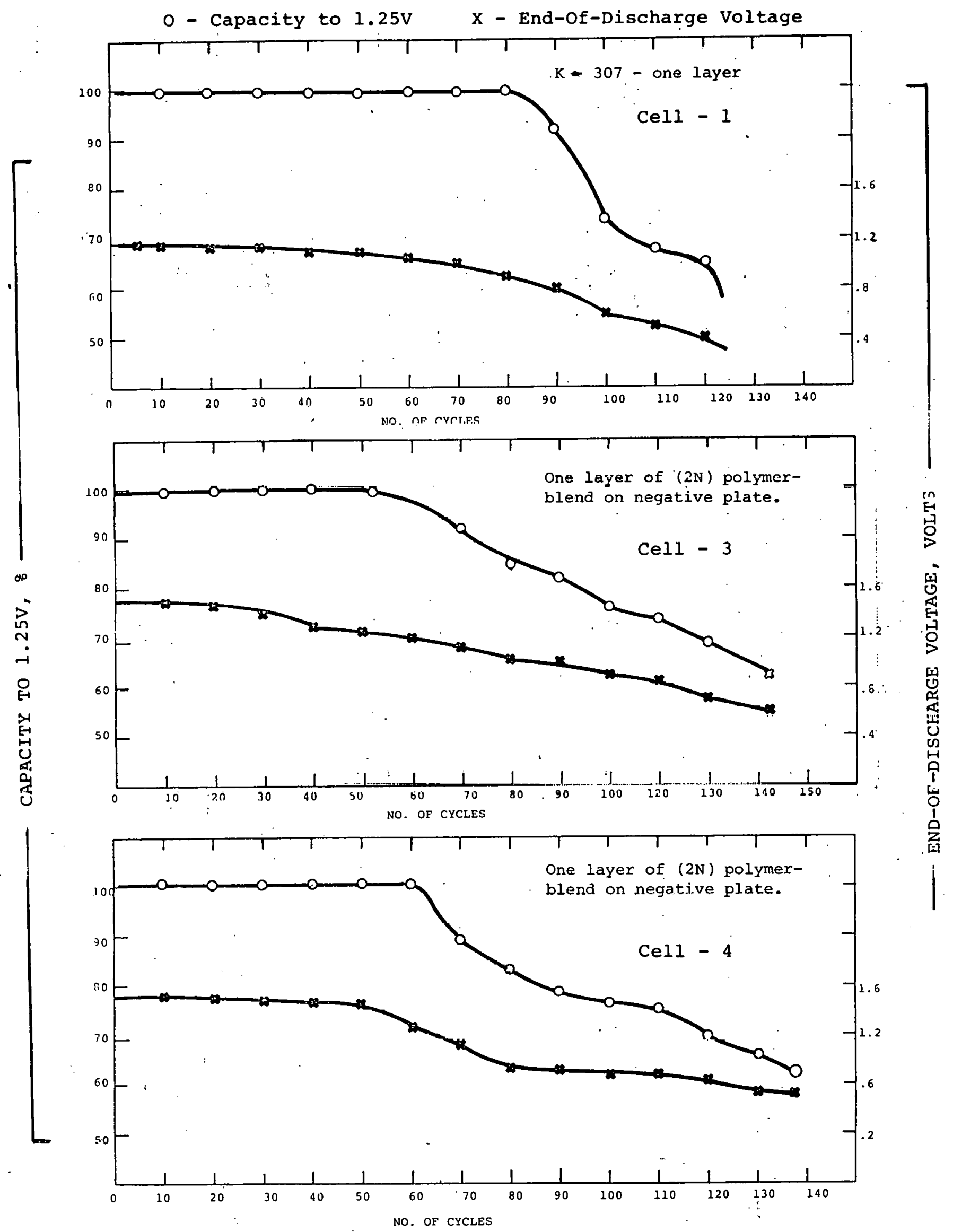

FIGURE III.5 DEPENDENCE OF CELL CAPACITY AND END-OF-DISCHARGE YOLTAGE ON NUMBER OF CYCLES

Page No. 118 
separator material can be achieved. Cycle life of the cells can probably be increased if uniform polymer-blend films can be produced on a casting machine.: The new separator material reduces. shape change of the negative electrode and does not degrade in the cell environment. Appearance and dimensions of film do not change significantly during the cycle life of the cell. So, the new separator material may withstand 500 deep cycles without chemical and mechanical degradation. But it is difficult to assume that any simple single layer or multi-layer separator system can prevent zinc penetration or shape change of the negative electrode for such a long cycle life in a $\mathrm{Ni}-\mathrm{Zn}$ battery. Therefore several attempts were made to design a special separator system for preventing zinc shorting the cell.

\subsection{DESIGN AND TEST RESULTS OF THE IMPROVED SEPARATOR SYSTEM}

\subsubsection{Small Cell Testing of Various Separator systems}

As discussed earlier, PVA-based separators can be classified

as selective membranes which prevent zinc penetration but do not retard shape change of the negative electrode. Polymer-blend separators are a combination of perm-selective and microporous materials, which prevent shape change but zinc dendrites grow through the films with cycling. To achieve both desirable properties, several approaches were evaluated:

1. A duplex separator consisting of the polymer-blend layer which was cast on the top of the PVA film.

2. A separator system consisting of a coating on the negative electrode of PVA in combination with one layer of polymer-blend film on the same electrode.

3. A separator system was prepared with three layers of polymer-blend films. Two external layers had the same composition. The internal layer contained a conductive powder in an amount of 50 wto of the polymerblend. The internal layer was rendered somewhat electroconductive (discharging metallic zinc dendrites). 
Before fabrication of celis, the separator films were tested for zinc penetration time. Test results are given in Table III.22. According to the data obtained, duplex material (PVA + polymer-blend) exhibited very good zinc stopping properties in comparison with crosslinked PVA which gave the best results prior to this test. The separator system with three layers of polymerblend films also showed a substantial increase in zinc penetration time... This experiment indicates that the combination of polymer-blend material and PVA materials increases time to zinc penetration.

Several cells were made and tested to examine the idea described above. Cycle life and results of failure analysis for severai celis are given in Table III. 23.

A cell with a duplex PVA and polymer-blend separator lasted 145 cycles until. the capacity dropped to $60 \%$. The presence of the polymer-blend layer reduced swelling and wrinkling of PVA film and, therefore, substantially descreased shape change of the negative electrode. zinc penetration was slowed by the PVA layer. Ihe cell worked much longer than cells with two layers of polymer-blend separator or two layers of PVA-based separator which both shorted after $56-70$ cycles.

The second design was a combination of PVA coating and one layer of polymer-blend formed as a bag on the negative electrode. The electrode was coated with solutions of the polymer-blend compocition and PVA; the hest resilt was the PVA coating. The cell performed for 146 cycles up to $80 \%$ of initial capacity which dropped very slowly. The PVA swelled but did not wrinkle and improved resistance to zinc penetration. Small amounts of zinc 
TABLE III. 22

TIME OF ZINC PENETRATION FOR IMPROVED SEPARATOR SYSTEM

\section{COMPOSITION}

Commercial PVA

PVA + Filler

75응 25 웅

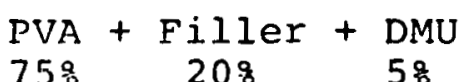

Multi-Layer (PVA + Polymer-Blend)

Polymer-Blend + (Polymer-Blend + Conductive Filler) + Polymer-Blend

Polymer-Blend + (Polymer-Blend + Conductive Filler) + Polymer-Blend
TIME, HrS.

7

8

11

$170(\sim 1 w k)$ 
TABLE III.23

EFFECT OF SEPARATOR CONFI GUPATI ON ON C YCLE LIFE AND F.AILURE MODE

Theo. Zinc Cap。 $(\mathrm{AH})=14.4 \mathrm{Ah}$

Electrode Size - H - 3-7/8" $\pm 1 / 16 "$

W- 2-7/8" $\pm 1 / 16 "$

$\mathrm{T}-.07^{\prime \prime} \pm .002 "$

Discharge $=2.5 \mathrm{~F} \times 1 \mathrm{hr}$

Charge Discharge Rätio $\left(\frac{\circ}{b}\right)=120 \%$

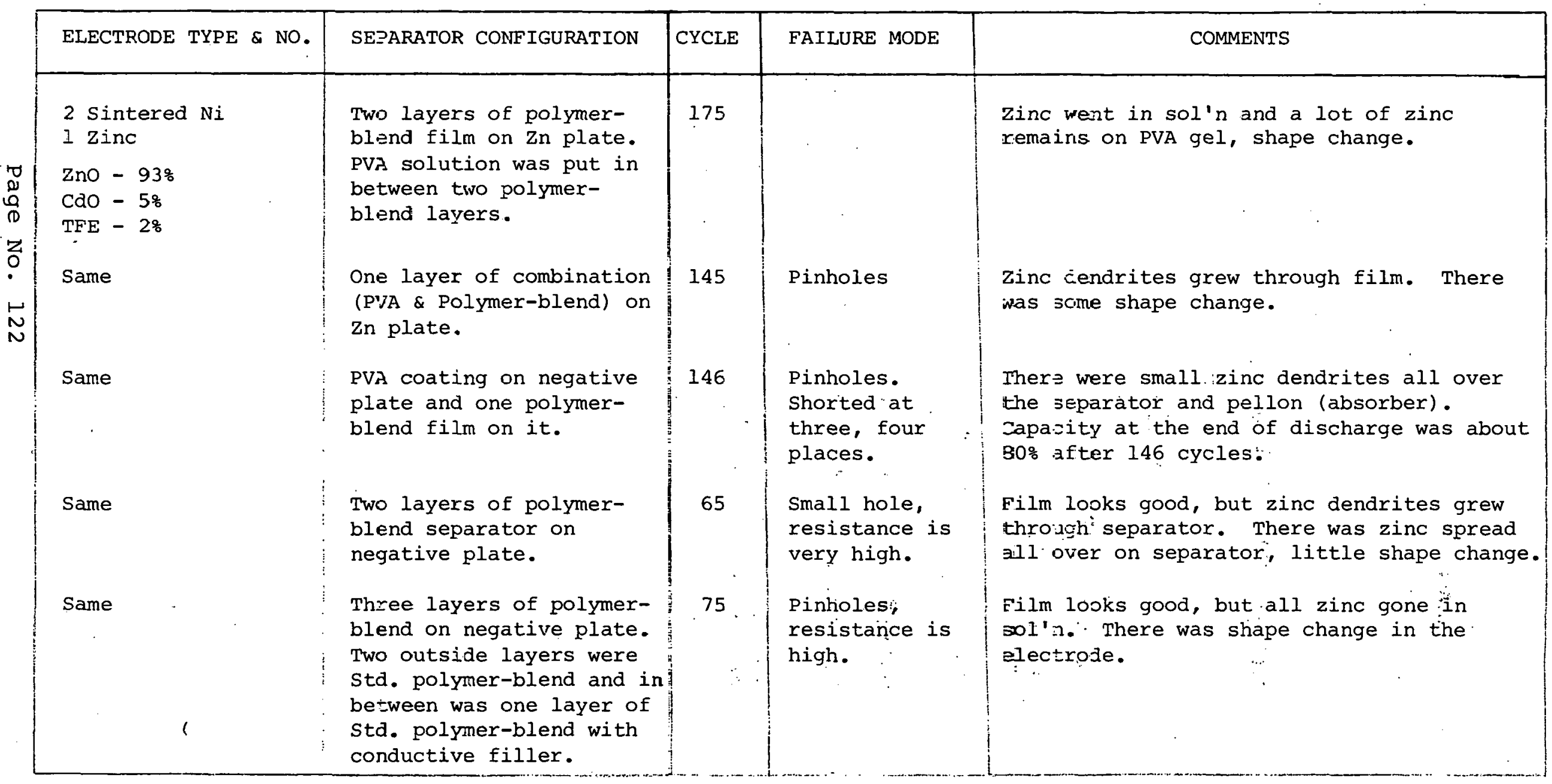




\section{ENERGY RESEARCH CORPORATION}

which could grow through the PVA coating were uniformly distributed in the polymer-blend separator so zinc did not form large dendrites. The cell with PVA solution between two layers of polymerblend films worked 175 cycles until the capacity dropped to $60 \%$. Failure analysis showed that a uniform layer of metallic zinc was deposited on PVA film (solution dried out) but PVA film did not swell or wrinkle at all. Therefore if the polymer-blend layer uniformly distributes zinc which penetrates the film, the PVA layer stops the penetration of zinc. The external layer of polymer-blend prevents PVA from excess swelling and wrinkling. This, combination resulted in the longest cycle life; and shape retention of the negative electrode was excellent.

Cells with three layers of separator material were tested in several different combinations:

1. Two polymer-blend external layers had the same composition. The internal polymer-blend layer contained a conductive filler in addition to components in the external layers.

2. The same two external layers of polymer-blend film but the internal layer contained PVA with 50\% conductive filler.

3. One external polymer-blend layer, an internal layer with PVA $+50 \%$ condutive filler and one external layer with PVA.

Different-cells tested with this separator system containing three layers of polymer-blend films did not exhibit promising results: Cycle life did not exceed 75 cycles. The main reason for such low performance was the high electrical resistance of the separator system. Cells with cellulose acetate coatings were tested and the results are given in Table III.24. The coating lost its physical integrity and dendrites 
TABLE III. 24

TEST RESULTS FOR CELLS WITH VARIOUS SEPARATOR SYSTEMS

THEORETICAL ZINC CAPACITY (AH) $=14.4 \mathrm{AH}$

ELECTROLE SIZE:

$$
\begin{array}{ll}
\text { H }-3-7 / 8^{\prime \prime} \pm 1 / 16 " & \text { DISCHARGE }=2.5 . \mathrm{A} \times 1 \mathrm{hr} . \\
\mathrm{W}-2-7 / 8^{\prime \prime} \pm 1 / 16^{\prime \prime} & \text { CHARGE/DISCHARG } \mathrm{RATIO}(\mathrm{z})=120 \% \\
\mathrm{~T}-.07 " \pm .002^{\prime \prime} &
\end{array}
$$

ELECTRODE

SEPARATOR

FAILURE

TYPE \& NO.

CONFIGURATION

CYCLE

MODE

COMMENTS

(1) 2:Full sintered $\mathrm{Ni}$ one layer of cross-linked

PVA on regat:ve plate.

52

Pinholes

sinc dendrites grow through

1 Full zinc

Plate was coated with

Cell shorted

seperator: There was shape change.

Zno - 938

Cellulose Acetate

CdO - 58

TFE -28

(2) 2 Full sintered $\mathrm{Ni}$ 1 Full zinc

Zno -938

CdO - 5\%

TEE -28
Negative plate: was

coated with polymer-blend

solution and Pellon

wrapped on both plates
46

Cell shorted

There were zinc dendrites. Coating vas rot thick enough.
(3) 2 Full sintered $\mathrm{Ni}$ Three-throw separator 1 Full zine

Zno -938

$\mathrm{CdO}-58$

TFE -28

(4) 2 Full sintered $\mathrm{Ni}$ 1 Full zinc

Zno $-93 \%$

CdO -58

- TFE_- 28

(5) 2 Full sinterea $\mathrm{Ni}$ I Full zinc

ZnO -938

CaO -58

- TFE - 28 polymer-blend.

The thira layer is PVA. film. One layer of standand

polymer-blend. The second yayer of

standard polvmer-blend + . conductive

filler. The thrid layer is standard

Very high
resistance
shape change
cell did nct
short

The first layer is standard polymer-blend. The seçond layer

156

Several

is polymer blend + conductive filler.

small

dendrites

shorted the

cell

Polymer-blend layer was adjacent to the In electr. Separator looks good. PVA does not swell. Not a lot of $\mathrm{Zn}$-was outside of separator bag. Shape change but not too much.
The first laver is standara

Folymer-blend. The second layer is Folymer-blend + conductive filler. The third layer is PVA
120

Shape chanse cell did not short
?VA layer was adjacent to the $\mathrm{zn}$ electr. A lot of $\mathrm{Zn}$ was outside of the separator bag. Cell lost capacity because of shape change 


\section{TABLE III.24}

TEST RISULTS FOR CELLS WITH VARIOUS SEPARATOR SYSTEMS

$\because$ THEORETICA ZINC: CAPACITY $(A H)=14.4 \cdots A H$

- FTRCTRODE SIZE: $\mathrm{H}-3-7 / 8^{\prime \prime} \pm 1 / 16^{\prime \prime}$

DISCHARGE $=2.5 \mathrm{~A} \times 1 \mathrm{hr}$.

$$
\begin{gathered}
W \stackrel{2}{-} 2-7 / 8 " \pm 1 / 16 " \\
\mathrm{~T}=.07 " \pm .002 " .
\end{gathered}
$$

CHARGE/DISCHARGE RATIO $(\xi)=120 \%$

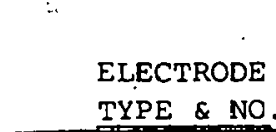

SEPARATOR

CONFIGURATION

FAILURE

MODE

COMENTS

(6) 2 Fill sintered $\mathrm{Ni}$ 1 Full zinc

One layer of standard

114 zinc made

Zinc went to the plate through wire

a bridge

and shorted it. There was shape change. polymer-blend on the

over the

zinc remains or film. It was uniformily

Zno -938 .

negative plate. Plate

separator.

distributed.

-.--TEE_-2 28

was coated with (PVA
$B A+D M U)$ solution

Cell shorted.

(7) 2 Full sintered $\mathrm{Ni}$.

One layer of PVA

(PVA + DMU) on

162

A small

It shorted. There was less shape change.

1 Full zinc

negative plate and

pinhole

Film looks good. Color of PVA did not

plate was coatec with

no - 938

a polymer-blend solution.

TFE - 28

(8) 2 Rolled $\mathrm{Ni}$

1 zinc

zna $-93 \%$

$\mathrm{CdC}-5 \mathrm{z}$

TFE $-.2 \%$
Two layers of palymer-blend. Pure PVA solution was inside

the polymer-bler.d bag.
Cell

increased

the internal resistance
PVA solution dried up and made the gap ketween the electrodes. There was shape change: 


\section{ENERGY RESEARCH CORPORATION}

grew through the separator. The coating consisting of a thin layer of polymer-blend without the separator bag was not sufficient to prevent zinc penetration and the cell shorted. Employing a polymerblend coating and a one layer bag of crosslinked PVA resulted in increased cycle life up to 162 cycles (see cell 7).

Three cells were fabricated with a separator system which. contained a layer of polymer-blend film filled with a conductive filler. Separator systems were made in three layers and electrically conductive standard polymer-blend film with conductive filler comprised the internal layer. The cell with this separator system worked for 75 cycles and lost capacity because of shape change. The cell did not short but the resistance of the separator system became very high. The second separator system contained one external layer of standard polymer-blend, an internal layer of standard polymerblend with a conductive filler, and one external PVA layer.' This system was tested in two variations. A layer of standard polymerblend, or PVA was in contact with the zinc electrode (see celis 4 and 5, accordingly). The cell in which the layer of standard polymerblend contacted the zinc electrode lasted 156 cycles and small dendrites grew through the separator. Very little $\mathrm{Zn}$ was outside of the separator bag. Shape change of the zinc electrode was not significant. The cell with the separator bag in which the PVA layer contacted the zinc electrode worked for 120 cycles and lost capacity as a result of shape change. Almost all zinc was outside of the separator bag and the cell was not shorted.

The cell with PVA coating on the negative plate and one layer of standard polymer-blend shorted after 114 cycles but zinc grew along the lead and created a bridge over the separator. The 


\section{ENERGY RESEARCH CORPORATION}

separator film looked very good; zinc did not penetrate through the polymer-blend film.

A zinc penetration test wa's performed on commercial separator systems. Two commercially available separator materials were tested: Celgard k-307 (polypropylene microporous film coated on both sides by cellulose acetate) and Celgard $\mathrm{K}-317$ (similar to $\mathrm{K}-3.07$ but the coating on one side is cellulose acetate to which $\mathrm{Ni}$ powder is added as a filler). Results obtained were comparad with data of zinc penetration time for ERC-developed separator systems (see Table III.25).

As indicated in the table, the zinc stopping ability of the polymer-blend film is higher than that of celgard $k-307$ and two layers of polymer-blend film with PVA solution between lasted twice as long as Celgard $\mathrm{K}-317$.

As discussed above, several separator systems developed at ERC allow an increase in cycle life of Ni-Zn cells (approximately two to three times greater than any other separator system with two or three layers of commercial material under the same cycling conditions). Development of more uniform polymer-blend film, with optimum properties of component and production technology for separator systems will permit a substantial increase in the cycle life of the $\mathrm{Ni}-\mathrm{zn}$ battery. Only after optimization of the properties for the described systems will it be possible to determine. which separator systen is the best for Ni-Zn batteries.

Moreover, performance differences between small and large cells will require changes in separator system properties.

Separator systems were also tested to examine optimum combinations and ability to reproduce materials. Three systems 
TABLE III. 25

Zn PENETRATION TIME FOR ERC-DEVELOPED AND COMMERCIALLY AVAILABLE SEPARATOR SYSTEMS

COMPOSITION

1. PVA solution ineidc

2. $\mathrm{K}-317$ (Celgard)

3. $\mathrm{K}-3.07$ (Celgard)

4. One layer polymer-blend
TIME IN HKS.

\section{0}

24

11.5

24 


\section{ENERGY RESEARCH CORPORATION}

tested were:

1. Crosslinked PVA coating and one layer of polymerblend separator bag on the zinc electrode.

2. Crosslinked PVA coating on two positive electrodes and one layer of polymer-blend separator bag on the zinc electrode.

3. Two-layer bag of polymer-blend separator film on the zinc electrode and crosslinked PVA solution between the layers of the polymer-blend film.

The cycle life and failure modes of the cells tested are given in Table III. 26 (for cells 1 thru 9). The cycle life of cells employing one layer of polymer-blend separator and PVA + boric acid + DMU coating on the negative electrode varied from 162 to 276 cycles, indicating that the combination tested has high potential to increase the durability of the Ni-zn batteries.. However, the optimum properties of coating and the polymer-blend film must first be determined.

The second combination was one layer of polymer-blend separator bag on the negative electrode and PVA + boric acid + DMU coating on the two positive electrodes. Cells with this system worked for 78 and 84 cycles. The reason for short cycle life of the cells was that too thick of a coating was used on the $\mathrm{Ni}$ electrodes. Therefore, electrical resistance of the separator system was too high. Experiments with this separator system will be continued.

The last combination was two layers of polymer-blend separator film and crosslinked PVA solution between the polymer-blend layers Cells with this configuration lasted 150 and 301 cycles. Two other cells performed for 310 and 440 cycles. The cell with an aqueous polymer solution worked for 310 cycles and maintained $100 \%$ 
TABLE III. 25

EFFECT OF OTHER SEPARATOR CONFIGURATIONS ON CYCLE LIFE AND FAILURE MODE OF THE CELLS

THEORETICAL EINC CAPACITY $(\mathrm{AH})=14.4 \mathrm{AH}$

$$
\begin{aligned}
\text { ELECTRODE SIZE: } & \text { H }-3-7 / 8 " \pm 1 / 16 " \\
& \text { W }-2-7 / 8 " \pm 1 / 16 " . \\
& T-.07 " \pm .00{ }^{\prime \prime}
\end{aligned}
$$

DISCHARGE $=2.5 \mathrm{~A}^{\prime \prime} \times 1 \mathrm{hr}$.

CHARGE/DISCHARGE RATIO $(8)=120 \%$

\section{ELECTRODE \\ SEPARATOR}

TYPE \& NO.

(1) 2 Rolled $\mathrm{Ni}$

1 Zine

Zno - 938

CdO - 5\%

TFE - 28

CONFIGURATION

One layer of (2N) polymer-blend

on negative plate and the

positive plate was coated

five times with (PVA + DMJ +

BA) solution.

\section{FAILURE}

MODE

High

Resistance

$\begin{array}{ll}78 & \text { MODE } \\ \because & \text { Resigh } \\ & \end{array}$

\section{COMMENTS}

Separator looks good. There was shape change in negative plates. Plates was dried, resistance was too high.

(2) 2 Rolled $\mathrm{Ni}$ 1 zinc

One layer of (2N) polyner-blend

84 on negative plate and the positive

High plate was coated five times with

Resistance

Shape change evident. Coating swells (PVA + DMU + BA) solution.

Zno - 938

Cdo - 5\%

TFE - 28

(3) 2 Rolled Ni 1 zinc

one layer of (2N) polyraer-blend

162

Shape on negative plate. Plate was coated with (PVA + DMU + EA)

Change

solution.

$\mathrm{CdO}-58$

TFE - 28

(4) 2 Full Sintered $\mathrm{Ni}$

1 Zinc

$\mathrm{ZnO}-938$

$\mathrm{CAO}-5 \%$

TFE - 28

(5) 2 Rolled $\mathrm{Ni}$

1 Zinc

Zno - 938

Cdo - 58

TFE - 28

One layer of NPB on negative

plate. Plate was coated with

(PVA + $\mathrm{BA}+\mathrm{DMU}$ ) solution.

Pelion on the plates.
276

Two layers of polymer-jlend on negative plate with pure ?VA solution inside the bag.
150

เ

$\mathrm{High}$

Resistance
Separator looks good. There was shape change. All zinc was gone in solution. Cell was too light.
Shape There was zinc in cell. Shape

$\begin{array}{ll}\text { Shape } & \text { There was zinc in cell. Shape } \\ \text { Change } & \text { change observed. Separator was goód. }\end{array}$ 
TABLE III. 26

EFFECT OF OTHER SEPARATOR CONFIGURATIONS ON CYCLE LIFE AND FAILURE MODE. OF THE CELLS

THEORETICAL ZINC CAPACITY $(\mathrm{AH})=14.4 \mathrm{AH}$

ELECTRODE SIZE: $\mathrm{H}-3-7 / 8 " \pm 1 / 16 "$

$$
\begin{aligned}
& W-2-7 / 8 "-1 / 16^{\prime \prime} \\
& T-.07 " \pm .002 "
\end{aligned}
$$

DISCHARGE $=2.5 \mathrm{~A} \times 1 \mathrm{hr}$.

CHARGE/DISCHARGE RATIO $(\%)=1208$

ELECTRODE

SEPARATOR

TYPE \& NO.

\section{CONFIGURATION}

MODE

(6) 2 Rolled $\mathrm{Ni}$

Two layers of polymer-blend with

301

Shape

$(P V A+B A)$ solution inside

Change

on negative plate. Pellon

on the plates.

Zno - 938

CdO - 58

TFE - 28

a

Two layers of polymer-blend with

polymer solution inside the

bag on negative plate. Pelion

310

on the plates.

Shape

Change.

Pinholes

ZnO -938
CdO -58

TFE - 28

(8) 2 Rolleä $\mathrm{Ni}$

1 Full Zinc

Zno - 938

CdO - 58

TFE - 28

(9) 2 Rolled $\mathrm{Ni}$

1 Full zinc

$\mathrm{ZnO}-938$

CdO - 58

TFE - 28

One layer of $\mathrm{NP}_{\mathrm{B}_{2}}$ on

negative plate was coated

with (PVA + BA) solution.

Pellon on the plates.

Two layers of polymer-blend on

negative plate (PVA + BA + DMU)

440

solution inside the bag. Pellon

on the plates.
Shape

Change
Cell Dried

Up." Shape

change.

plates swell and dry

zinc plate. There was shape change.

zinc dendrites grow through separator.

All

zinc remains on the lower half of

plate. There were some pinholes.

Solution inside the bag dried up and

took the form of thick layer. Too

much zinc on that layer.

pinholes solution aries up

and took the form of thick layer. 


\section{ENERGY RESEARCH CORPORATION}

capacity up to 100 cycles. A cell with an aqueous PVA + boric acid + DMU solution lasted 440 cycles with over 375 cycles above $75 \%$ of initial capacity. The cell which lasted 150 cycles was made with an extra quantity of the solution. Therefore, the internal resistance of the cell increased when the solution dried up. Data obtained show that the separator system containing a liquid yields the longest cycle life thus far and reproducibility of the results is very good.

Test conditions for small Ni-7n single electrode cells were changed in order to achieve a greater acceleration of the test. The discharge current was increased from 2.5 to 3 amperes for the same discharge time (one hour). The charge remained at 120\%. Cells which were under test during this changeover adjusted their performance after 3 to 4 cycles and show almost the same capacity after an additional 50 cycles.

The dependence of cell capaoity and the end of discharge voltage on number of cycles is presented in Figures III.6 thru III.8. Comparison of the curves of cells containing different separator systems shows that several cells which worked for more than two hundred cycles had a second step on the curves in coordinates capacity versus number of cycles. The capacity started to decline after 60 or 80 cycles like prevlous curves. But at a certain level, the capacity stopped decreasing and did not change during the next 120 to 200 cycles. Understanding the nature of the second step and gaining the ability to produce cells having long second steps at high capacity levels can probably solve the problem of durability for $\mathrm{Ni}-\mathrm{Zn}$ batteries. Results obtained with two layers of microporous separator 
o- Capacity to $1.25 \mathrm{~V} \quad \mathrm{X}$ - End-Of-Discharge Votlage
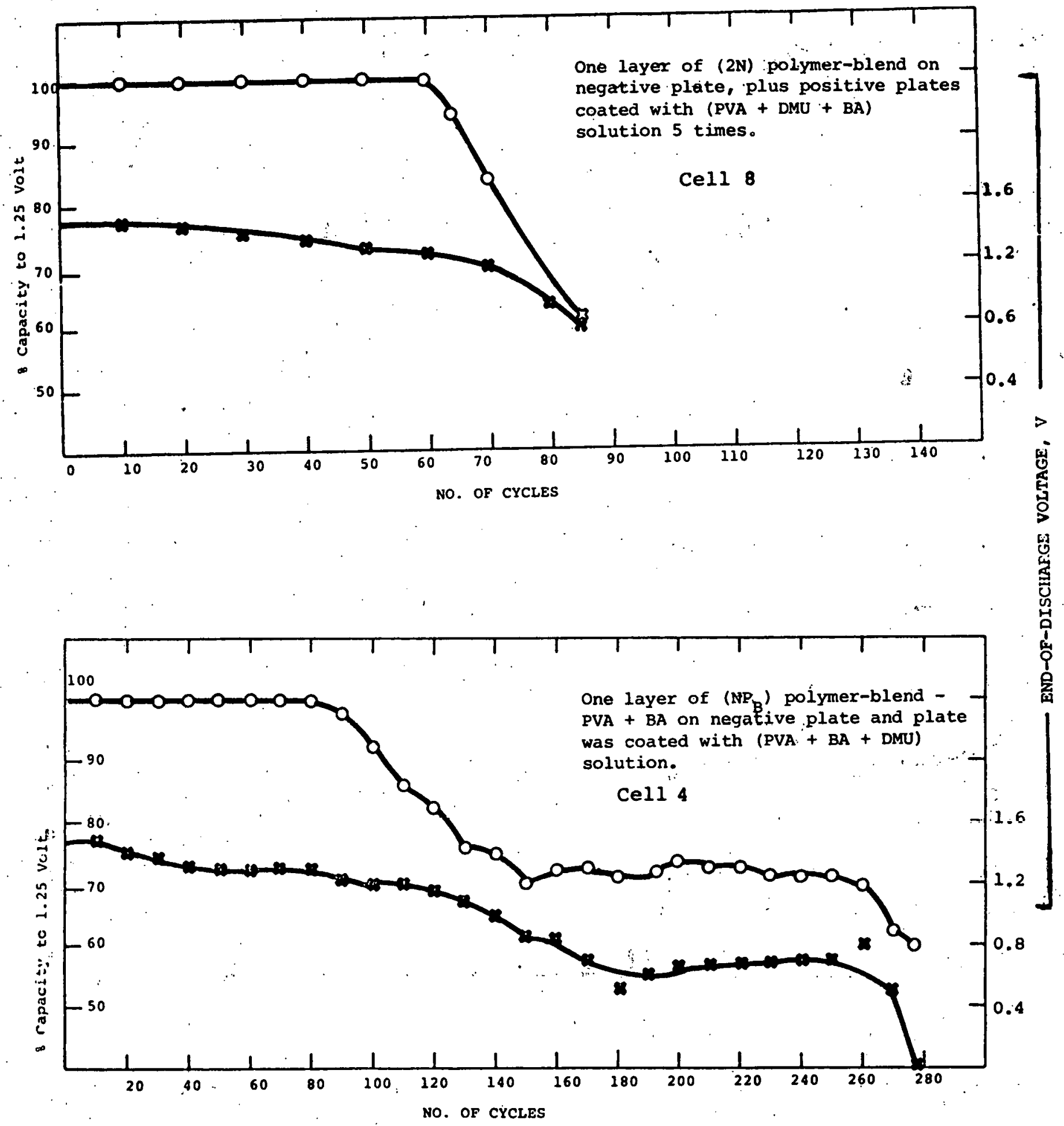

FIGURE III.6 DEPENDENCE OF CELL CAPACITY AND END-OF-DISCHARGE VOLTAGE ON NUMBER OF CYCLES, CELLS 6 AND 8 

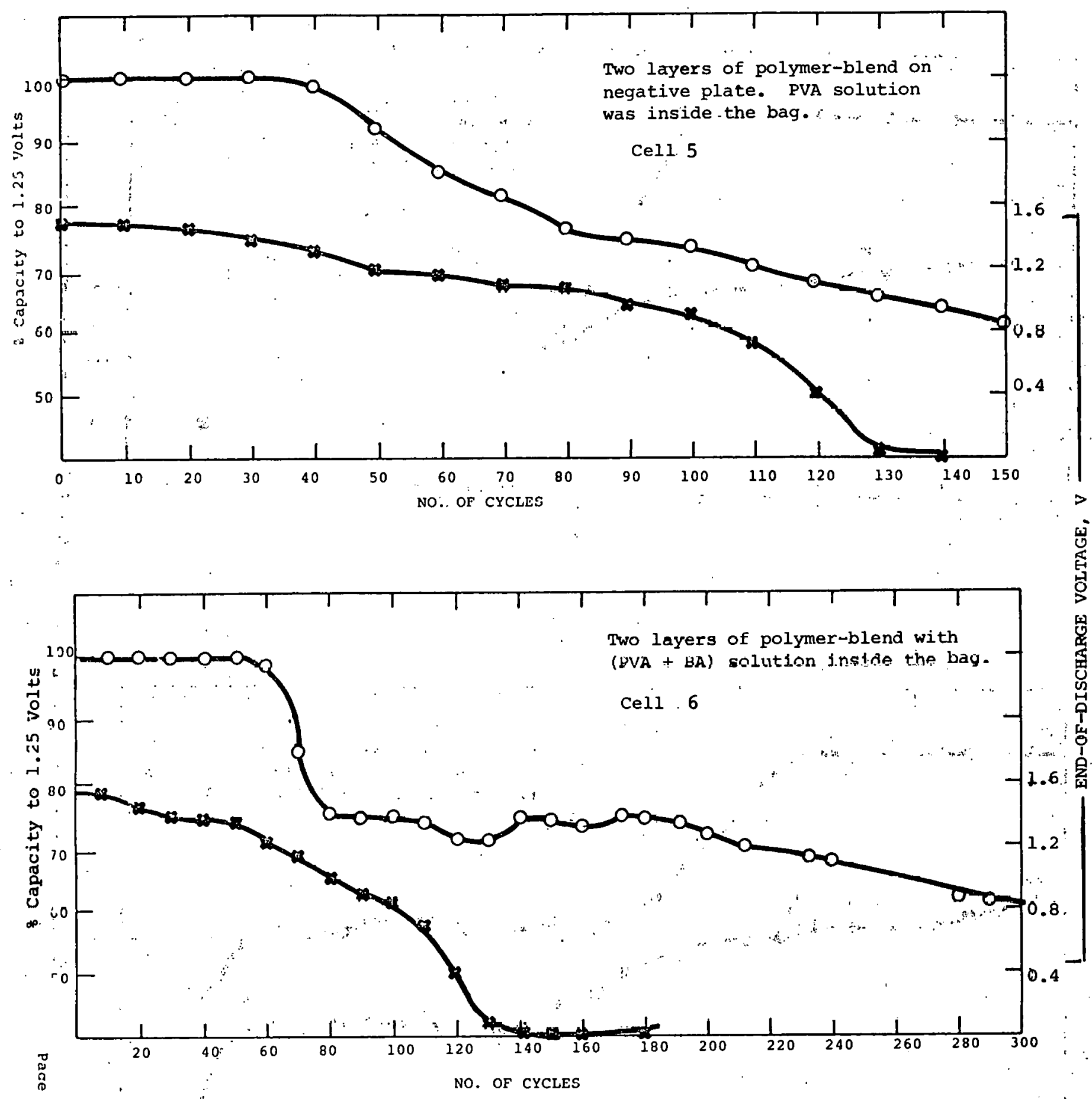

FIGURE III.7 DEPENDENCE OF CELL CAPACITY AND END-OF-DISCHARGE VOLTAGE ON NUMBER OF CYCLES, CELLS 9 AND 10 


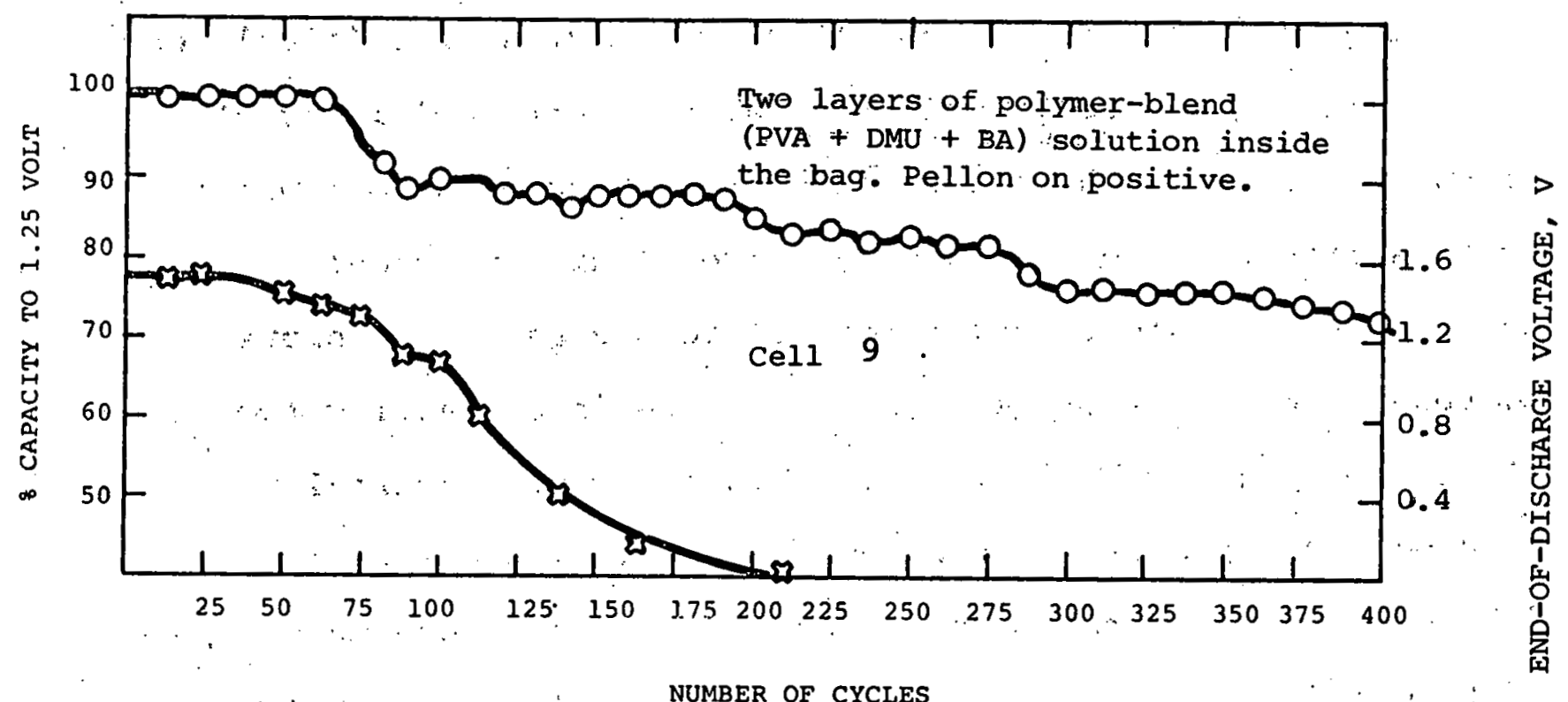

NUMBER OF CYCLES

FIGURE III.8 DEPENDENCE OF CELL CAPACITY AND END-OF-DISCHARGE

VOLTAGE ON NUMBER OF CYCLES, CELL 9 


\section{ENERGY RESEARCH CORPORATION}

film and polymer solution between the layers show promise in improving cycle life of Ni-zn small cells. The problem is to immobilize the polymer solution which is used in liquid form between two layers of microporous separtor film. The presence of a liquid layer in the separator system creates difficulties in assembling the cells and in obtaining reproducibility of results. To keep the liquid layer entrapped in a form which wash suitable for cell assembly, several highly porous. materials were used: nylon net, fibrous glass mat, porous carbon sheet and fibrous nickel mat. Cells containing two layers of polymer-blend film and highly porous material impregnated in aqueous an polymer solution were made and tested. Results are given in Table III.27. According to the data obtained, introduction of an additional porous layer impregnated in liquid solution resulted in a sharp increase in electrical resistance of the separator system and in loss of substantial cycle life of the cells. Other methods for immobilizing the liquid layer are presently being investigated. Development of a more uniform duplex separator film comprised another part of the development studied. Duplex separator material containing a polymer-blend film cast on top of improved PVA film has more uniform properties. Electrical resistance of the separator film is between 100 and $135 \mathrm{~m} \Omega-\mathrm{in}^{2} / \mathrm{mil}$ and zinc penetration time is about 92 hours (almost three times higher than for Celgard $\mathrm{K}-317$ ). 
TABLE III. 27

CYCLE LIFE OF THE CELLS CONTAINING IMMOBILIZERS FOR LIQUID LAYER IN SEPARATOR SYSTEM THEORETICA.L ZINC CAPACITY (AH) $=14.4 \mathrm{AH}$

$$
\begin{aligned}
\text { ELECTRODE SIZE: } & \text { H }-3-7 / 8^{\prime \prime} \pm 1 / 16^{\prime \prime} \\
& \text { W }-2-7 / 8^{\prime \prime} \pm 1 / 16^{\prime \prime} \\
& T-.07 " \pm .002^{\prime \prime}
\end{aligned}
$$

DISCHARGE $=2.5 \mathrm{~A} \times \mathrm{ihr}$

CHARGE DISCHARGE RATIO(z) $=1208$
ELECTRODE
TYPE \& NO

(1) 2 Rolled Ni 1 zinc

Zno - 938

CdO -58

TFE - 28
SEPARATOR

CONFIGURATION

Two layers of polymer-blend and PVA solution in the bag on negative plate. Pellon on the positive plates.

\begin{tabular}{ll} 
FAILURE \\
CYCLE \\
\hline
\end{tabular}

30 Very high resistance
COMMENTS

\begin{tabular}{|c|c|c|c|c|}
\hline $\begin{array}{l}\text { (2) } 2 \text { Rolled } \mathrm{Ni} \\
1 \text { Zinc } \\
\text { ZnO }-938\end{array}$ & $\begin{array}{l}\text { Two layers of polymer-blend and } \\
\text { polyurethane net and polymer } \\
\text { solution was in bag on negative } \\
\text { plate. Pellon on the positive }\end{array}$ & 24 & $\begin{array}{l}\text { High } \\
\text { resistance }\end{array}$ & $\begin{array}{l}\text { Polyurethane net does not have any } \\
\text { resistance against kOH. It dissolved } \\
\text { and made a thick layer with polymer } \\
\text { solution. Resistance was too high. }\end{array}$ \\
\hline
\end{tabular}

Made a very thick spongy layer of

PVA. Resistance was high.

CdO - 5q

TFE - 28

(3) 2 Rolled $\mathrm{Ni}$

1 Zinc

plate.

solution. Resistance was too high.

Zno - 938

CdO -58

TFE - 28

(4) 2 Rolled $\mathrm{Ni}$

1. Zinc

(2N) polymer-blend bag on negative

24

High

Net combines with solution.

plates. Polymer solution and (nylon

resistance

net) was in the bag. Pellon on

negative plates.

Zno $-93 \%$
cao $-5 \%$

TFE - 28

(5) 2 Rolled Ni

1 Zinc

Zno - 938

CdO -58

TFE - 28
(2N) polymer-blend bag on negative
plates. Polymer solution and a fil

24

bag.
High

resistance
Net looks very sticky.
(2N) polymer-blend bag on negative plate and nickel net was inside the bag. Pellon on positive plates.
High

resistance zinc dendrites grow and stay in net.

48 High Zinc dendrites grow and stay in net.


Results presented in this section prove that specially designed separator systems have better properties than any single separator material or simple multi-layer separators. For example:

\section{Cell Description}

1. With one layer of crosslinked PVA

2. With nne layer of

polymer-blend separator

3. With two layers of. crosslinked PVA

4. With two layers of polymer-blend separators

5. With two layers of Celgard $\mathrm{K}-307$ (Celgard is the best commercially available separator material so far).
Maximum Cycle Life

85 ćycles

138 cyclec

89 cycles

105 cycles

Employing a combination of a polymer-blend separator material and crosslinked PVA results in an increased cycle life of the Ni-Zn small cells up to 250 cycles. The use of ERC separators with liquid semi-permeable membranes results in cells which can perform for more than 300 reproducible cycles. However, data obtained during cycling small cells do not always correlate with testing results for large cells. Therefore, assembling and testing of small cells were discontinued and full size, single eletrode cells have been produce.

2.3.2 Testing Different Separator Systems in Full size, Single Electrode Cells

Several separator systems which showed promise in small cells were tested in full size, single electrode cells containing one negative and two positive electrodes. 


\section{ENERGY RESEARCH CORPORATION}

Cell Design

2 Full Rolled Ni Plates

1 Full zinc Plate

$$
\begin{array}{ll}
\text { Ni Plate: } & H-9 " \pm 1 / 16^{\prime \prime} \\
& \text { W }-6-1 / 2 " \pm 1 / 16^{\prime \prime} \\
& \text { T }-.082^{\prime \prime} \pm .002^{\prime \prime} \\
\text { Zinc Plate: } & \text { H }-9 " \pm 1 / 16^{\prime \prime} \\
& \text { W }-6-1 / 2 " \pm 1 / 16^{\prime \prime} \\
& \text { T }-.053^{\prime \prime} \pm .002^{\prime \prime}
\end{array}
$$

Theoretical capacity of $\mathrm{Ni}: 24.4 \mathrm{Ah}$

Theoretical Capacity of $\mathrm{Zn}: \quad 80 \mathrm{Ah}$

\section{Test Conditions}

1. Charge at 4 amp. for 6 hours

2. Discharge at 10 amp. for 2 hours

3. Overcharge $20 \%$

4. Depth of Discharge on Negative $25 \%$

5. Rate of Discharge $C / 2$

Test results are given in Table III.28. A cell with one layer of polymer-blend separator worked for 96 cycles, down to $60 \%$ of initial capacity. The failure mode was shape change of the zinc electrode and no traces of zinc penetration through the separator were visible. The second cell tested contained one layer of duplex PVA + polymer-blend film and two positive plates were coated by PVA + BA. The cell lasted 105 cycles and the failure mode was also shape change. The positive electrodes swelled and the center of the negative electrode dried out in both cases and essentially reduced the working area of the electrodes and the capacity of the cell. Very similar results could be seen after Cells 3 and 4 were taken apart. The first preliminary conclusions 
TABLE III. 28

CYCLE LIFE OF FUL: SIZE SINGLE ELECTRODE CELLj

\section{THEORETICAL NI CA.PACITY (AH) $=24 \mathrm{AH}$}

ELECTRODE SIZE: H $-9^{\prime \prime} \pm 1 / 4 "$

$$
\begin{aligned}
& w-6-1 / 2 " \pm 1 / 4 " \\
& T-.082 " \pm .002 "
\end{aligned}
$$

ELECTRODE TYPE \& NO.

(1) 2 Rolled Ni

\section{SEPARATOR} COMFEGURATION

(2N) Polymer-blend cn negative plate and Pellon on the

\begin{tabular}{|c|c|}
\hline CYCLE & $\begin{array}{l}\text { FAILURE } \\
\text { MGDE }\end{array}$ \\
\hline 96 & Shape \\
\hline & \\
\hline
\end{tabular}
positive plates.

\section{COMMENTS}

Separator looks good. There was no pinhole in it. Ni plates swell too much and dries up the plate.

1 Full zine

$\mathrm{znO}-888$

$\mathrm{Bi}_{2} \mathrm{O}_{3}-10$

\begin{tabular}{|c|c|c|c|c|c|}
\hline & $\begin{array}{l}2 \text { Rolled Ni } \\
1 \text { Full zinc } \\
\text { ZnO - } 938 \\
\text { CdO - } 58 \\
\text { TFE - } 28\end{array}$ & $\begin{array}{l}\text { One layer of NPB on negative } \\
\text { plate. and Pellon on positive } \\
\text { plate. The positive plates } \\
\text { weze coated with (PQA + BA) } \\
\text { solu=ion. }\end{array}$ & 105 & $\begin{array}{l}\text { Shape } \\
\text { Change }\end{array}$ & $\begin{array}{l}\text { Tieze was significant shape change } \\
\text { o.: zinc plate. Ni plates swell } \\
\text { a.d dries the zinc plate. }\end{array}$ \\
\hline (3) & 2 Positive Rolled Ni & $\begin{array}{l}\text { One layer of polymer-blend on neg. } \\
\text { plate. plate was coated with } \\
\text { PVA solution. Only Pellon } \\
\text { on tile plate. }\end{array}$ & 75 & $\begin{array}{l}\text { Shaoe } \\
\text { Change }\end{array}$ & $\begin{array}{l}\text { Separator looks good. There was } \\
\text { siape change. Separator looks } \\
\text { strong without any pinholes. }\end{array}$ \\
\hline & $\begin{array}{l}\text { I Full } \mathrm{zin}=\text { (règative) } \\
\mathrm{ZnO}-88 \mathrm{z} \\
\mathrm{Bi}_{2} \mathrm{O}_{3}-10 \mathrm{~B} \\
\mathrm{TFE}-2 \mathrm{z}\end{array}$ & $\begin{array}{l}\text { Only Pellon on the positive } \\
\text { plates. }\end{array}$ & & & $\therefore$ \\
\hline 14: & 2 Positive Solled Ni & $\begin{array}{l}\text { Thze? layers separazor \& polymer- } \\
\text { blend film. Inside layer was } \\
\text { filled with a condactive filler. }\end{array}$ & 75 & $\begin{array}{l}\text { Stape } \\
\text { Change }\end{array}$ & $\begin{array}{l}\text { A. lot of zinc outside of the } \\
\text { separator bag. Too high electrica } \\
\text { resistance of the separator system }\end{array}$ \\
\hline
\end{tabular}

TFE - 28

1 Full zinz (negative)

$\mathrm{ZnO}-88 \mathrm{~m}$

$\mathrm{Bi}_{2} \mathrm{O}_{3}-10 \mathrm{~B}$

$M F F .=23$ 


\section{ENERGY RESEARCH CORPORATION}

to be made from these tests are that large zinc electrodes are more sensitive to shape change than small electrodes, and pressure developed in big cells is much higher than in small cells.

Several full size, single electrode cells were produced with the most promising separator systems (see Table III.29). A cell with two layers of polymer-blend filin and PVA + BA + DMU solution worked 105 cycles down to $60 \%$ of initial capacity. The failure mode was shape change of the zinc electrode. The positive electrodes swelled and squeezed the solution out of the negative which dried up the center of the plate. Swelling of the positive electrodes reduced the electrode working area and the capacity of the cell. The dependence of cell capacity on number of cycles (see Figure III.9). started to decline after 30 cycles and did not exhibit a second step as found in small cells with the same separator system.

The cell with two layers of polymer-blend film and a polymer solution between the layers of separator film worked for 90 cycles and showed $67 \%$ of initial capacity (see Figure III.10). A cell with two sintered positive electrodes had $100 \%$ capacity up to 60 cycles and showed about $80 \%$ of initial capacity after 84 cycles. Only one layer of polymer-blend separator film was used in the last cell. These facts indicate that the swelling phenomenon influences full-size cell performance much more than cycle life of small cells since sintered positive plates do not swell to any great extent.

Negative electrodes are now being developed which are much less sensitive to the pressure exerted by the positive electrodes. Several cells with the improved zinc electrode and different 
$20 \mathrm{Ah}$



FIGURE : III. 9

DEPENDEMCE OF CETL CAPACITY ON NUMBER OF CYCLES 
$20 \mathrm{Ah}$

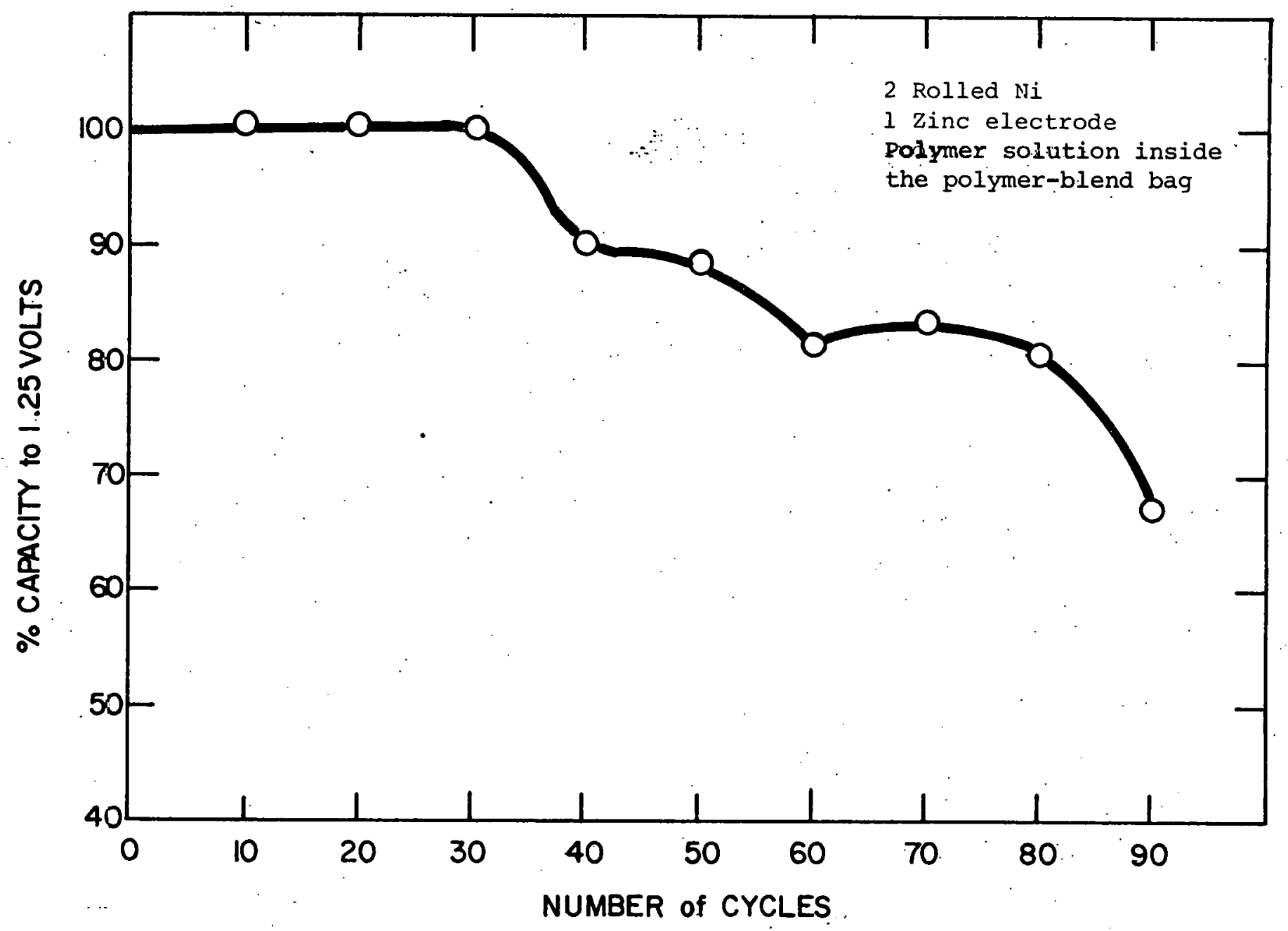

FIGURE III. 10

DEPENDENCE OF CEIL CAPACITY ON NUMBER OF CYCLES 
TABLE III. 29

CYCLE LIFE OF THE FULL SIZE CELLS CONPAINING LIOUID LAYER IN THE SEPARATOR SYSTEM

THEORETICAL NI CAPACITY $(A H)=24 \mathrm{AH}$

ELECTRODE SIZE: H - 9"

พ $-6-1 / 2 " \pm 1 / 4 "$

$T-.082 " \pm .002 "$

ELECTRODE

SEPARATOR

CONFIGURATION

CYCLE FAILURE

PVA solution inside polimer-

105

MODE

(1) 2 Rolled Ni

blend bag.

shape

Change

COMMENTS

1 Zinc

2no - 888

$\mathrm{Bi}_{2} \mathrm{O}_{3}-108$

TFE - 28

(2) 2 Sintered Ni

1 Zinc

Zno - 888

$\mathrm{Bi}_{2} \mathrm{O}_{3}-108$

TFE - 28

(3) 2 Rolled $\mathrm{Ni}$

1 zinc

Zno - 958

CdO - 18

$\mathrm{PbO}-28$

TFE - 28

(4) 2 Rolled Ni

1 Zinc

(2N) polymer-blend bag. on

90

Pinholes

There were too many zinc dendrites

negative plate. Polymer

on separator. It had pinholes,

solution was in the bag..

salution dried and made thick layer

of -polymer.

solution dried up and there was

shape change. Ni plates swell too

mish, separator looks a little brittle.

żno - 958

PbO - 28

TFE - 28

CaO - 18

(5) 2 Rolled Ni

1 zinc

Zno - $95 \%$

$\mathrm{PbO}-28$

TFE - 28

CdO - 18
(2N) polymer-blend on

115

\begin{tabular}{|c|c|c|c|}
\hline $\begin{array}{l}\text { ( } 2 \mathrm{~N}) \text { polymer-blend bag in } \\
\text { negative plate. PVA solution }\end{array}$ & 98 & $\begin{array}{l}\text { Shape } \\
\text { Change }\end{array}$ & $\begin{array}{l}\text { Sclution dried and made thick layer. } \\
\text { sinc dendrites were all over the layer. }\end{array}$ \\
\hline
\end{tabular}

in the bag.

negative plate. Pelion on

Shape

Change.

There was shape change but more uniform. 
TABLE III. 29

CYCLE LIFE OF THE FULI SIZE CELLS CONTAINING LIQUID LAYER IN THE SEPARATOR SYSTEM THEORETICAL Ni CAPACITY $(\mathrm{AH})=24 \mathrm{AH}$

ELECTRODE SIZE: H-

W - 6-1/2" $\pm 1 / 4^{\prime \prime}$

T - .082" $\pm .002^{\prime \prime}$

ELECTRODE

SEPARATOR

TYPE \& NO.

CONFIGURATION

\begin{tabular}{cl} 
CYCLE & $\begin{array}{l}\text { FAILURE } \\
\text { MODE }\end{array}$ \\
\hline 2 & $\begin{array}{l}\text { Shape } \\
\text { Change }\end{array}$
\end{tabular}

COMMENTS

(6) 2 Rolled $\mathrm{Ni}$

One layer of $x-317$ and one 1 Zinc

layer of $\mathrm{K}-307$ on negative

plate. PVA solution was

Change

Solution dried. There was too much zno - 888

$3 \mathrm{i}_{2} \mathrm{O}_{3}-108$

inside two layers. Pellon

zinc on film. Ni coating comes off

TFE - 28

on positive plates.

(7) 2 sintered $\mathrm{Ni}$

1. Zinc

Zno - 888

$\mathrm{Bi}_{2} \mathrm{O}_{3}-108$

TFE - 2\%
Two layers of (2N) polymer-

blend on negative plate.

Polymer solution was inside the

bag. Pellon on positive plates.
92

Shape

Change

Separator looks good. Zinc dendrites grow and remain on film. There was shape change. 


\section{ENERGY RESEARCH CORPORATION}

separator systems were produced and they are now on test.

According to data obtained, cells with different separator

systems had almost the same cycle life (between 90 and 115 cycles).

This fact indicates that other limiting factors exist. Compari-

son of dependencies of capacity on number of cycles for small and

full size single electrode cells shows that the number of cycles attained before capacity decline is about equivalent and the rate uf this decline is almost the same. Therefore, average ryole life is about 100 to 120 cycles. However, in small cells it. was. possible to get a second capacity plateau for the dependence of capacity on number of cycles by employing a liquid membrane type separator. Only cells having a second plateau worked for more than 200 cycles. Conditions for obtaining a second plateau in performance for full-size cells have not been determined thus far. Attempts were continued to immobilize the polymer solution, which ic uocd in liquid form leLwenll rwo layers of microporous. separator film. Plastic bags were constructed from microporous Celgard film; and PVA or other polymer agueous solutions were put in the baqs which were then sealen nn top. The bags were thon put in a freezer to immohilize the polymer colution. Frozen flat bags with polymer solution were used as a separator in the cells. Cells with one negative and two positive electrodes containing one layer of Celgard k-306 or polymer-blend film and one frozen bag on each side of the negative electrode were assembled and tested. The cells performed for 90 and 80 cycles to $60 \%$ of initial capacity (see Table III.30). The capacity of the cells started to decline after 40 cycles (see Figures III.11 and III.1.2). Postfailure examination has shown that all solution was squeezed out 
TABLE III. 30

TEST RESULTS OF THE FULL SIZE CELLS CONTAINING DIFFERENT SEPARATOR SYSTEMS

\section{THEORFTICAL CAPACITY OF CELL $=24 \mathrm{AH}$}

EIECTRODE SIZE: H $-9^{\prime \prime}$

$$
\begin{aligned}
& w-6-1 / 2 " \\
& T-.082 \pm .002 "
\end{aligned}
$$

ELECTRODE

TYPE \& NO

SEPARATOR

CONFIGURETITN

One layer of $\mathrm{K}-306$ and bag

of $\mathrm{k}-306$ with polymer solution

inside on the negative plate.

FAILURE
CYCLE MCDE

1) 2 Rolled $\mathrm{Ni}$

1 zinc

Zno - 958

Pbo -28

Cdo -18

TEE - 28

\section{$90 \quad$ Strape}

Change
COMMENTS

Excessive zinc dendrites were in

the cell. Eelgard turned brown

at some places. Polymer solution

dried up. There was shape change.

$\mathrm{CdO}-18$

TFE - 28

(3) 2. Rolled $\mathrm{Ni}$

1 Zinc

Owe layer of $(2 \mathrm{~N})$ polymer-

80

end on pcsitive plates.

Shape

Two bags of K-306 and polymer

solution irside the bag.

$\mathrm{ZnO}-958$

$\mathrm{PbO}-28$

CdO -18

TFE - 28 
TABLE III. 30

TפST RESULTS OF THE FULL SIZE CELLS CONTAINING DIFFERENT SEPARATOR SYSTEMS

$$
\begin{aligned}
& \text { THEORETICAL CAPACITY OF CELL }=24 \mathrm{AH} \\
& \text { ELECTRODE SIZE: } \mathrm{H}-9^{\prime \prime} \\
& \mathrm{W}-6-1 / 2^{\prime \prime} \\
& \mathrm{T}-.082 \pm .002^{\prime \prime}
\end{aligned}
$$

ELECTRODE

TYPE \& NO.

(5) 2 Rolled $\mathrm{Ni}$

1 Zinc

$\mathrm{ZnO}-95 \%$

$\mathrm{PbO}-28$

$\mathrm{CdO}-1 \%$

TFE - 28
SEPARATOR

\section{CONF IGURATĨON}

One layer of (2N) polymer-

blend and one layer of $\mathrm{k}-306$ on negative plate. Pellon on positive plates.

\section{FAILURE}

CYCLE MODE COMMENTS

120 Cell Dried, cell dried up. Special middle part Shape of both positive and negative

Change electrode was too dry. Most of the zinc was on pellon and separator. dimost all zinc was gone from plate. Shape change.
Three layers of Celgard negative plate. Pellon on positive plates.
47 Three layers of Japanese

PVA on negative plate. Fellon on positive plates.
Shape

Change
Separator swells. Shape change in zinc electrode.
1 zinc

Zno - 958

PbO - 28

CdO - 18

TFE - 28 
from the space between the electrodes and therefore the use of a polymer solution layer in a separator system of full-size cells does not result in increasing the cycle life of the cells.

The problem of optimum void space in the cell case relates to optimum pressure in the cell during cycling. Three similar cells were assembled with three layers of Celgard $\mathrm{K}-306$ on the negative plates. The difference was only in the number of shims which filled the void space in the case. The cell with eight shims represented normal, assembling conditions. The second cell had seven shims with 1/16" more void space than the first cell. The third cell contained six shims of 1/8" more void space than the first cell. The cells were assembled and tested during this month.

The cell with $1 / 8$ " void space could not be charged up during eight manual cycles and was disassembled. The negative electrode was not charged up at all. The cells with normal void space and with 1/16" extra void space were charged up after four manual cycles and were put on automatic cycling. During the first 48 to 50 cycles the cells performed identically but after that the cell with 1/16" extra void space started to decline whereas the cell which represented normal assembling conditions continued to show $100 \%$ of capacity. $:$ After 80 cycles, the "normal" cell was still yielding $100 \%$ of capacity but the cell with extra void space was showing only $60 \%$ of initial capacity. The cell with normal pack pressure performed 160 cycles down to $60 \%$ of initial capacity. This experiment shows that lack of pressure in cell case is probably as detrimental as excessive pressure.

Two cells containing three layers of Celgard $\mathrm{K}-306$ as a 
FIGURE III.11

CELL 1

DEPENDENCE" CF CELI CAPACITY ON NLMBER OF CYCLES

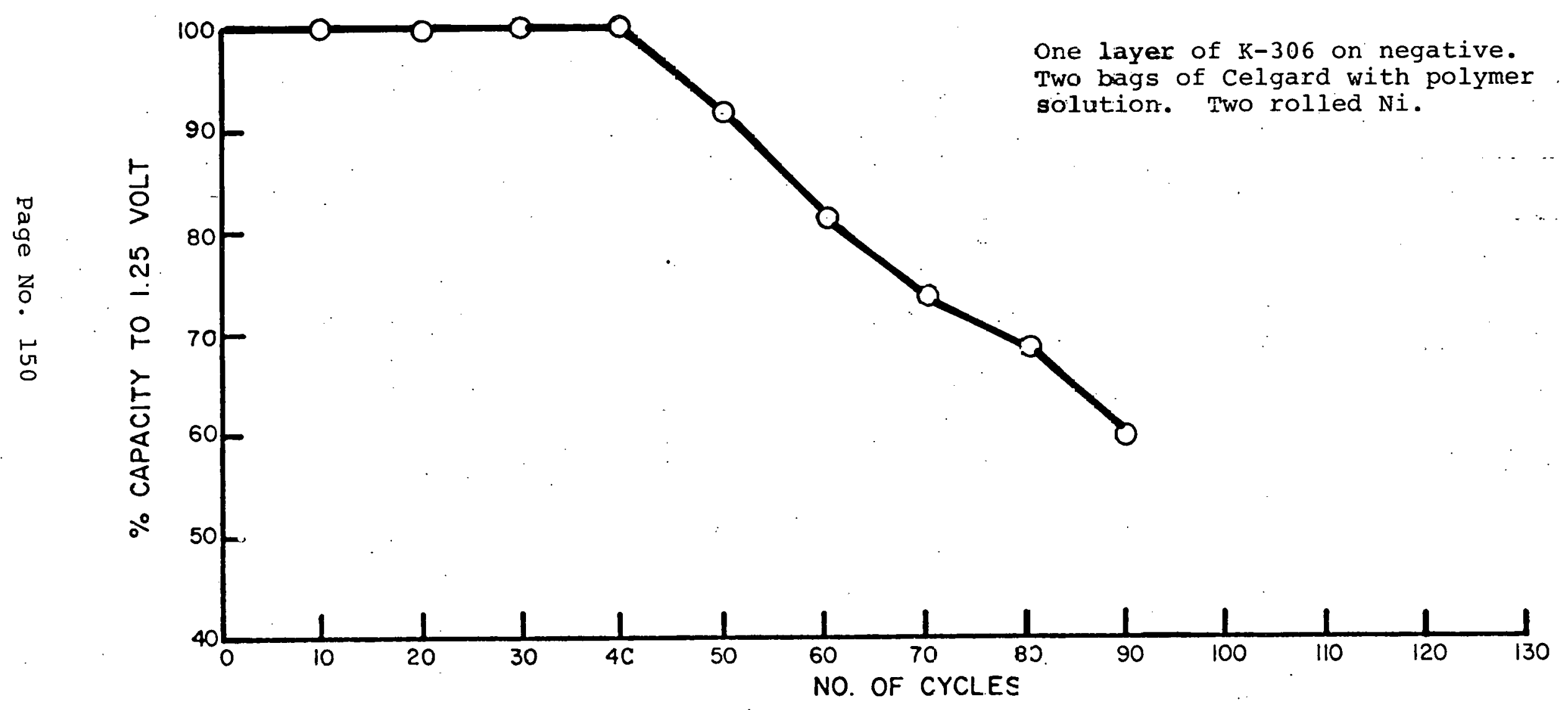




\section{FIGURE III. 12}

CELL 2

DEPENDENCE OF CELL CAPACITY ON NUMBER OF CYCLES

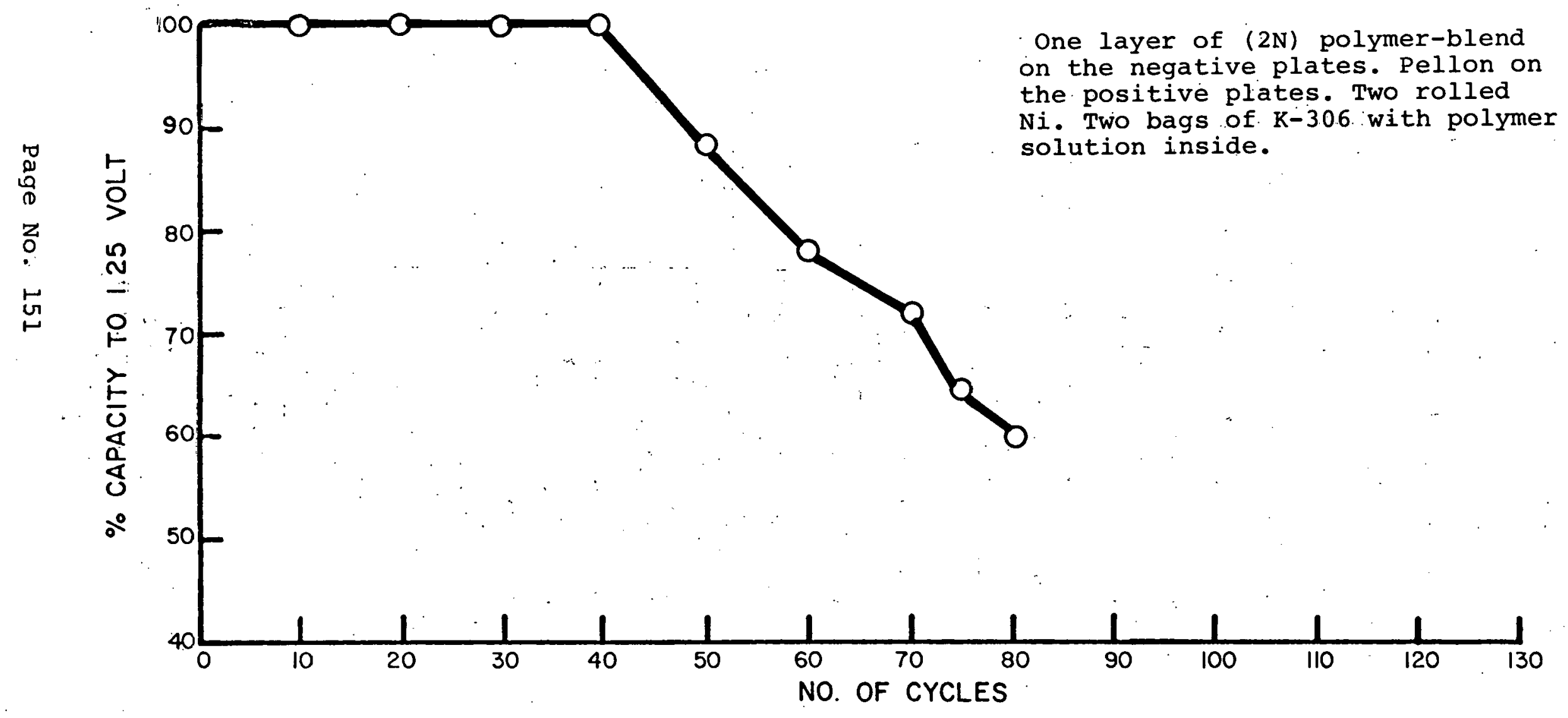


separator in one cell and one layer of Celgard K-306 with two. layers of nylon-based separator film in another showed 126 and 120 cycles, relatively, in full-size, 20 Ah cells (see Table

III.30 and Figures III.13 and III.14).

3.0 CONCLUSIONS

3.1 PVA-BASED SEPARATOR MATERIALS

- PVA crosslinked by using a mixture of DMU and boric acid has shown improved chemical stability in an alkaline cnvironmont.

- Evaluation of crosslinked PVA indicates that it has improved mechanical and physical properties, Cycle life of the cells with one layer of separator increased the 8.5 cycles compared to the 60 cycles of commercial PVÁ:

- Attempts to increase the degree of crosslinking by using other reagents did not result in improvement of the properties in comparison with PVA crosslinked by DMU and boric acid.

- The mechanism of electrolyte permeability in PVA films was studied. The presence of non-equilibrium and equilibrium conditions for electrolyte permeabjility of PVA films containing agueous KOH solution or residual water was explained from the view point of changing the diffusion mechanism of permeability

Diffusion of the electrolyte through the relatively dry polymer is realized hy formation and hreaking down of intermolecular bonds between the polymer and solvent. Activation energy of diffusion depends on the quantity of residual or absorbed solvent in the film. Change in this quantity results in variation of permeability properties and causes a non-equilibrium period of permeability.

- Diffusion of the electrolyte through the wet polymer is realized by the mechanism of solvent self-diffusion. Activation energy of self-diffusion is low and does not depend on quantity of solvent in the film. Therefore, permeability through the wet polymer has an equilibrium characteristic.

- Usually about $20 \%$ of the solvent is necessary to localize intermolecular interaction in the polymer and proceed from concentration-dependent diffusion to self-diffusion of the solvent. Local concentration of water in PVA is much higher than the average concen-

Page No. 152 
FIGURE III. 13

CELL 5

DEPENDENCE OF CELL CAPACITY ON NUMBER OF CYCLES

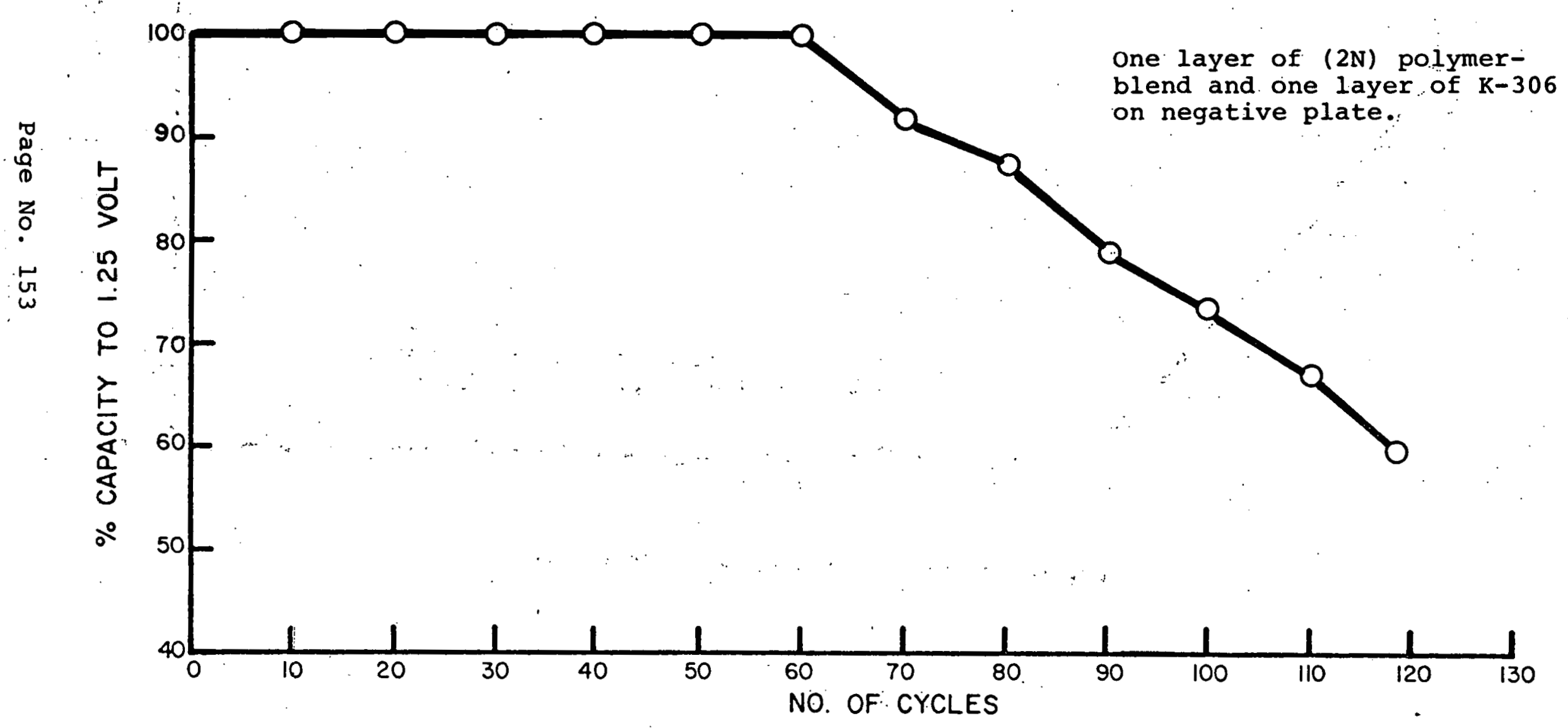


FIGURE III:14

CELL 6

DEPENDENCE DF CELL CAPACITY ON NUMBER OF CYCLES

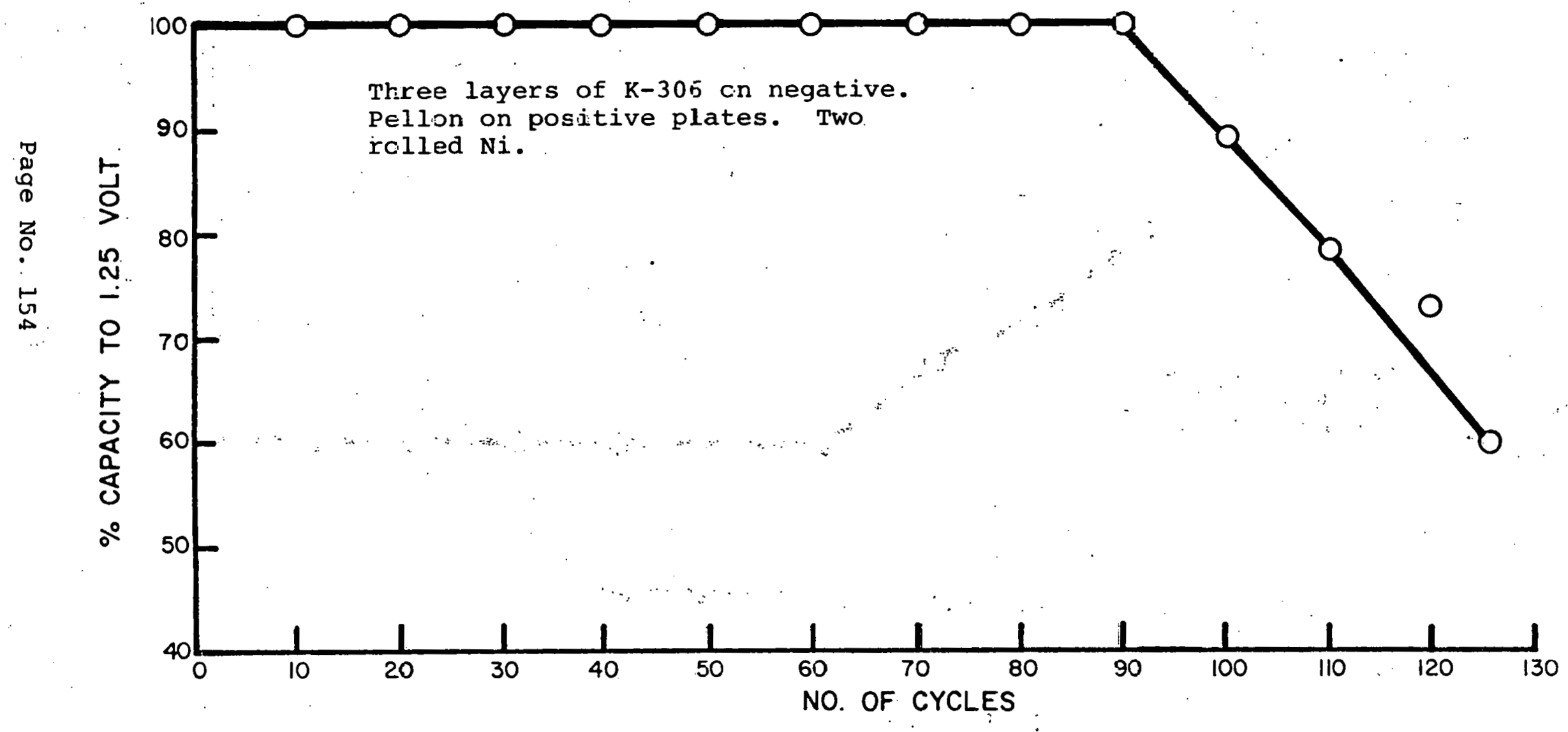


and, therefore, only $6 \%$ of the average weight concentration of water is enough to create conditions for equilibrium electrolyte permeability through PVA membranes.

- Crosslinking PVA as a separator material increases the probability of cell failure by shape change, and reduces. the hazard of $z$ inc penetration.

3.2 POLYMER-BLEND SEPARATOR MLTERIALS

- Properties of polymer-blend separator film were improved considerably during the period under review.

- Electrical resistance of the film is in the range of 30 to $150 \mathrm{~m}-i \mathrm{n}^{2} / \mathrm{mil}$ and can be regulated. Employing polymer-blend films in $\mathrm{Ni-Zn}$ cells results in a substantial reduction of shape change in the negative electrode.

- Comparison of cycle life of cells containing celgard K-307 (cellulose acetate coated on both sides of Celgard 3400) and polymer-blend separator film shows that the cells with one layer of polymer blend film achieved 132 and 138 cycles. Cells with one and two layers of Celgard $\mathrm{k}-307$ lasted 120 cycles regardless of whether one or two layers of the film were employed.

\subsection{DESIGN AND TEST RESULTS OF THE IMPROVED SEPARATOR SYSTEM}

- Duplex separator material consisting of the polymerblend layer which was cast on the top of the PVA film results in an increase in cell life up to about 200 cycles.

- The combination of one layer of polymer-blend film with a PVA coating on the negative electrode results in an increase in the cycle life of $\mathrm{Ni}-\mathrm{Zn}$ cells up to 150 cycles.

- A separator system with three layers of PVA and polymerblend films in which the inner polymer-blend layer (in addition to the normal components) contains a conductive filler amount of 50\%, gives a maximum of 156 cycles.

- The best results were obtained with a separator system containing two layers of polymer-blend film and polymer solution in a liquid form placed between the polymer-blend layers. Reproducible results were obtained in the range of 300 to 400 cycles.

- Any improved separator system allows achievement of longer cycle life compared to simple multi-layer systems of similar materials. 


\section{ENERGY RESEARCH COAPOAATION}

4.0 FUTURE WORK

During this period, several improved separator systems were developed and tested. These systems are promising candidates for use in full size Ni-Zn cells. Therefore the tasks for the next period of work will include:
a) Detailed evaluation of performance in large plate, 20 Ah and 250 Ah size cells.
b) Improvement of the separator system to achieve max- imum cycle life of full-size cells.
c) Development of the production technology for polymer-blend and PVA base separator films.
d) Study of long-term stability of separator materials. 


\section{REFERENCES}

1. Philipp, W.H. and Hsu, Li Chen, "Method for the In-Situ Crosslinking of Polyvinyl Alcohol Films for Battery separator Application in $\mathrm{KOH}$ Electrolyte", paper presented at $156 \mathrm{th}$ Electrochemical Society Meeting, Los Angeles, CA, October, 1979.

2. Design of the zinc penetration test cell and description of apparatus and procedure were taken from the book "Characteristics of Separators for Alkaline Silver Oxide Zinc Secondary Batteries", Edited by J.E. Cooper and Arthur Fleischer.

3. Lonsdale, H.K., Merten, U., Riley, R.L., J. Appl. Polymer Sci., 4. 1341,1865 .

4. Reitlinger, S.A. "Pronitsaemost' Polimernykh Materialov", Khimiya, Moskva, 1974 .

5. Yasuda, H., Lamaze, C.E., Ikenberry, L.D., Makromol Chem., 19, 118,1968 .

6. Vieth, W.., Douglas, A.S. Am. Chem. Boc., Polymer Prepr., 9 , 1556,1968 .

7. Riley, R.L,, Lyons, C.R., Merten, U., Desalination, 2, 177, 1970.

8. Rosenbau, S., Mahon, J.J., Cotton, O., J. Appl. Polymer Sci., $10,2041,1967$.

9. Dodin, M.G., ACS 179th National Meeting, Houston, Texas, March 1980.

10. Tager, A.A., "physical Chemistry of Polymers" Khimiya, Moskva, 1968 .

11. Chalykh, A.E., Vasenin, R.M., Vysokomolekulyarhye Soedineniya, Seriya A., 8, No. $11,1966$. 
ENERGy RESEARCH CORPORATION

SECTION V.

DEVELOPMENT OF SEALED

NICKEL-ZINC CELLS - (TASK IV) 


\section{ENERGY RESEARCH CORPORATION}

\subsection{INTRODUCTION}

The goal of this phase of the ANL nickel-zinc program is to determine the feasibility of operating large size cells in a sealed condition. Exploratory studies are being carried out in 20 Ah size cells to establish baseline construction and mode of operation parameters for sealed cells. The benefits of running $\mathrm{Ni}-\mathrm{Zn}$ cells sealed include low maintenance and extended life due to oxygen recombination, which reduces zinc electrode state-of-charge, thereby inhibiting dendrite growth.

Early work in the program had developed 20 Ah cells which had good initial performance but poor cycle stability. Major problems which have inhibited cycle performance are electrolyte redistribution and hydrogen gas build-up. The hydrogen buildup has been solved with the development of catalytic recombination devices. To improve cell wetting, work has been done in the past year with experimental separator and absorber materials, as well as sealed cell designs which are run with an excess of electrolyte. This report presents the progress and results achieved over the past year in the program. 


\section{ENERGY RESEARCH CORPORATION}

\subsection{TECHNICAL DISCUSSION}

\subsection{EXPERIMENTAL SEPARATOR AND ABSORBER DESIGNS}

Early in the year, the best separator design tested in sealed cells consisted of four layers of Celgard 3401 separator interspersed with layers of Pellon polyamide absorber felt. The importance of the extra layers of absorber is due to the fact that the cells are run electrolyte-starved.

cells with the celgari//Pellon separatur design cxhibited good initial performance, but were limited to about 30 cycles due to electrolyte redistribution during cycling. Over the past year, new materials from Celanese, Kimberly-Clark, and in-house were tested in sealed cells.

Experimental polymer-blend made at ERC was tested in sealed cells with separator designs as follows:

Ce11 2W

Woven 2 layers

(+) Nylon Bag/ ERC Film/Pellon///Pellon/ERL E'lim/Pellun(-)

Ce11 2X

Same 3eparator system but with Pellon absorber on (+) plate

The F.RC material had exhibited good performance in small cell testing performed under the separator development task of this project. However cells $2 \mathrm{~W}$ and $2 \mathrm{x}$ showed high voltages and gassing rates on charge, accepting less than 6 Ah charge input before pressure built up to 20 psig. Cell voltages at the end-of-charge were above $2 \mathrm{~V}$ for both cells. The performance of these cells suggests that the polymer-blend film does not wet sufficiently for use in electrolyte-starved cells. 
Sealed cells were also tested with three variations of Celgard separator materials. Cell CE-l was built with a Celgard/ cellophane laminate, CE-2 contained cellulose-acetate coated Celgard (coated on one side), and $\mathrm{CE}-3$ contained Celgard coated on both sides with cellulose acetate. Each cell contained three layers of the Celgard film, with Pellon absorber wraps on the positive and negative electrodes. Flooded formation cycles were run on the cells prior to sealed testing, with the following results:

\begin{tabular}{|c|c|c|c|c|}
\hline Ce11 & Separator & $\begin{array}{c}\text { Flooded Formation } \\
\text { Capacity, Ah }\end{array}$ & $\begin{array}{c}\text { Charge Input } \\
\text { To 20 psig, Ah }\end{array}$ & $\begin{array}{c}\text { Drained Sealed } \\
\text { Capacity, Ah }\end{array}$ \\
\hline CE-1 & $\begin{array}{l}\text { Celgard/Cellophane } \\
\text { Laminate }\end{array}$ & 20 & 14.3 & 0 \\
\hline CE-2 & $\begin{array}{l}\text { Cellulose Acetate } \\
\text { Coated Celgard } \\
(1 \text { side) }\end{array}$ & 19.2 & 20.9 & 12.2 \\
\hline CE-3 & $\begin{array}{l}\text { Cellulose Acetate } \\
\text { coated Celgard } \\
(2 \text { sides) }\end{array}$ & 20 & 18.1 & 17.0 \\
\hline
\end{tabular}

Capacity for Cell CE-1 did not improve in subsequent tests and the cell was not cycle tested. When drained and sealed, the cell exhibited charge voltages in excess of $2.5 \mathrm{~V}$ and delivered no capacity, indicating that the laminate film did not retain enough liquid for use in electrolyte starved cells. Cells $\mathrm{CE}-2$ and $\mathrm{CE}-3$ were cycle tested with platinum catalyst packets in the cells to recombine hydrogen and oxygen. The cells were equipped with pressure switches which terminated charge when cell pressure reached 20 psig. The cells were. 
charged at 3.67 amps to 20 psig (or $22 \mathrm{Ah}$ ) and discharged at 10 amps to $1.25 \mathrm{~V}$ (or $20 \mathrm{Ah}$ ). Test results are given in Table IV. 1 .

While the cell with the coating on one surface never delivered more than 13.8 Ah capacity, Cell CE-3 with Celgard coated on both sides ran for 32 cycles before capacity fell below $60 \%$ of nominal (12 Ah). This cycle performance is comparable to cells with a Celgard/Pelion separator system and indicates that tle vellulose acctate coating significantly improves wetting of the Celgard material.

The three $C E$ cells contained 5\% cdo zinc electrode additive. Three more cells were made with the coated celgard film (designated $\mathrm{K}-306$ ) and zinc electrodes with $2 \% \mathrm{Pbo}$ and $1 \% \mathrm{CdO}$ binary additive. As in the CE cells, 3 layers of $\mathrm{K}-306$ were used with Pellon electrode wraps. Two cells, designated $5-1-1$ and S-1-2, were built with sintered positive electrodes. A third cell, s-2 was built with rolled, pressed electrodes. Formation and cycle test data for these cells are given in Table IV. 2 .

During flooded, vented formation cycles, the cells delivered more than $20 \mathrm{Ah}$. On the second cycle the electrolyte was drained from the culls and they were acaled prior to the discharge. The only cell to be adversely affected by the electrolyte removal was $\mathrm{s}-2$, with the rolled positive electrodes. This indicates that the rolled positive plate is more sensitive to reduced electrolyte inventory than is the sintered plate. 
TABLE IV. 1

CYCLE TEST RESULTS OF CELLS WITH COATED CELGARD FILM

\begin{tabular}{|c|c|c|c|}
\hline \multicolumn{4}{|c|}{ CELL CE-2 } \\
\hline CYCLE \# & $\begin{array}{l}\text { CHARGE INPU } \\
\text { TO } 20 \text { PSI } \\
\end{array}$ & $\underline{\mathrm{ECV}}$ & CAPACITY (Ah) \\
\hline 1 & 15.1 & 2.00 & 13.8 \\
\hline 3 & 14.2 & 1.97 & 12.5 \\
\hline 5 & 13.3 & 2.01 & 10.0 \\
\hline 7 & 12.4 & 2.01 & 8.8 \\
\hline 9 & 12.4 & 2.02 & 8.8 \\
\hline 11 & 12.0 & 2.05 & 8.3 \\
\hline 13 & 11.5 & 2.05 & 8.1 \\
\hline \multicolumn{4}{|c|}{ CELL CE-3 } \\
\hline CYCLE \# & $\begin{array}{l}\text { CHARGE INPUT } \\
\text { TO } 20 \text { PSI } \\
\end{array}$ & $\begin{array}{l}\text { END OF } \\
\text { CHARGE VOLTAGE }\end{array}$ & $\begin{array}{l}\text { DISCHARGE } \\
\text { CAPACITY TO } 1.25 \mathrm{~V}\end{array}$ \\
\hline 1 & 1.3 .3 & 1.90 & 11.2 \\
\hline 3 & 14.2 & 1.95 & 10.2 \\
\hline 5 & 22 & 1.95 & 16.9 \\
\hline 7 & 22 & 1.92 & 17.5 \\
\hline 9 & 22 & 2.00 & 18.1 \\
\hline 11 & 22 & 1.97 & 18.1 \\
\hline 13 & 22 & 1.95 & 17.5 \\
\hline 15 & 22 & 1.95 & 17.5 \\
\hline 17 & 21 & 1.95 & 15.0 \\
\hline 20 & 19 & 1.95 & 14.3 \\
\hline 24 & 18 & 1.92 & 13.8 \\
\hline 28 & 16.5 & 1.92 & 12.5 \\
\hline 32 & 16.0 & 1.92 & 11.8 \\
\hline 35 & 15.5 & 1.90 & 10.0 \\
\hline
\end{tabular}

TABLE IV. 2

PERFORMANCE DATA FOR SEALED CELLS

$S-1-1, S-1-2$, and $s-2$

ALL DISCHARGES AT 1OAMPS

Flooded formation cycle $32 \mathrm{Ahr}$ charge

CELL NO. :

s-1\# 1

$\mathrm{s}-1 \# 2$

$\mathrm{S}-2$

Positive Electrode sintered

Sintered Rolled-Pressed

Capacity

rapasity Capacity

to $1.25 \mathrm{~V}$ ECV to $1.25 \mathrm{~V}$ ECV to $1.25 \mathrm{~V}$

Flooded 32Ahr charge. Sealed, starved loAmp discharge

Sealed $4 \mathrm{Amp}$ charge, 32.5Ahr input

ECV to 1.25

\begin{tabular}{ll|ll}
1.931 & 22.2 & 1.879 & 21.3 \\
\hline
\end{tabular}

Automatic cycle: $3.67 \mathrm{Amp}$ charge $\times 6 \mathrm{Hrs}$; 10Amp discharge $\times 2 \mathrm{Hrs}$.

CYCLE NO.

\begin{tabular}{|l|ll||ll||ll|}
\hline 1 & 1.75 & 18.9 & 1.79 & 17.9 & 1.75 & 19.0 \\
\hline 5 & 1.85 & 18.6 & 1.90 & 19.1 & 2.00 & $\begin{array}{c}>20 \mathrm{Ahx} \\
1.4 \mathrm{EDV}\end{array}$ \\
\hline 10 & 1.88 & 17.6 & 1.90 & 18.1 & 1.91 & 14.5 \\
\hline 15 & 1.90 & 18.5 & 1.90 & 16.0 & 1.90 & 13.0 \\
\hline 20 & 1.90 & 12.8 & 1.90 & 16.0 & 1.95 & 16.1 \\
\hline 25 & 1.90 & 11.8 & 1.87 & 15.0 & 1.96 & 14.0 \\
\hline 30 & & & 1.90 & 12.0 & 1.90 & 11.5 \\
\hline
\end{tabular}


FIGURE IV.1 PRESSURE AND VOLTAGE ON A 4A CHARGE FOR CELLS S-1-1, S-1-2 \& S-2
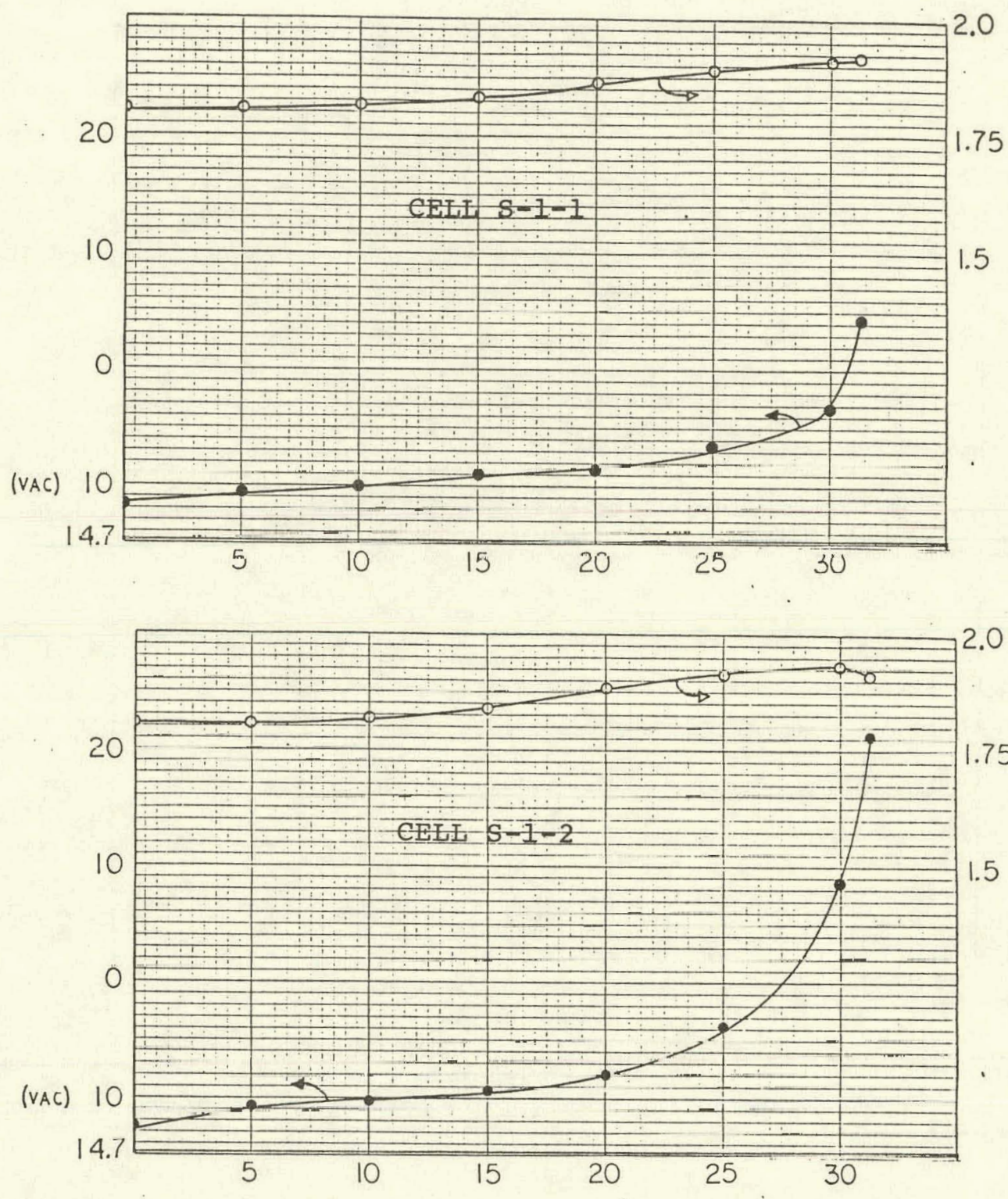

2.0

.75

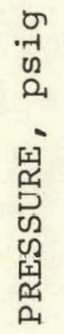

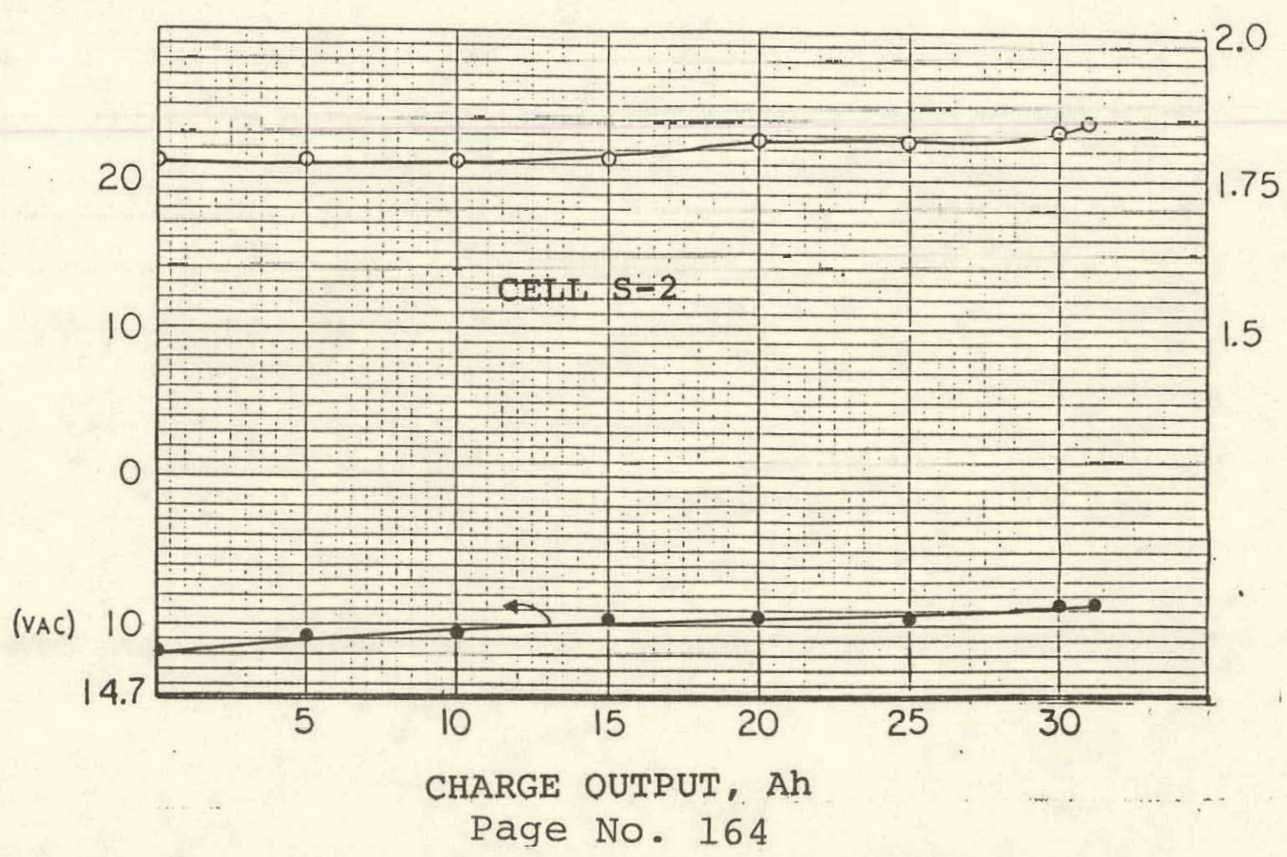




\section{ENERGY RESEARCH CORPORATION}

The cells were then given a 4 amp charge in the sealed condition which lasted for 8.1 hours. Only one cell had built up pressure to 20 psig at this point. The pressure in cell s-2 rose to only 3.4 psia (from a 25 in. $\mathrm{Hg}$ vacuum) during charge. After this, the cell

delivered only $8.5 \mathrm{Ah}$, but capacity improved during cycling, with the cell eventually delivering a full 20 Ah discharge.

Cell S-1-1 developed 19 psia during charge and delivered 22.7 Ah capacity. Cell s-1-2 developed 33.5 psia on charge and delivered 21.2 Ah capacity. Figure IV.1 shows the pressure and voltage behavior of these cells during charge. Immediately following charge, the pressure decayed in cells s-1-1 and s-1-2 at 15.7 and $10.7 \mathrm{psi} /$ hour, respectively. Pressure increased in cell s-2 just after charge at a rate of $0.65 \mathrm{psi} /$ hour.

Following this test, the cells were put on the automatic cycle test described above. Relief valves set at 20 psig were used to allow full charge input. The cycle results are given in Table IV.2. Between Cycles 10 and 15, an equipment malfunction caused the cells to receive a $100 \%$ overcharge. The cells were then conditioned by discharging them to $0.0 \mathrm{~V}$, but the overcharge probably accelerated their failure.

In terms of cycle life (number of cycles with capacity more than 12 Ah) the three cclls were similar, although the cells with sintered Plales exhibited a more stable capacity. Following the cycle test, the cells were refilled, and tested vented to determine the extent to which dry-out had caused failure. Cell performance did not improve significantly and the data indicated that the cells were short-circuited. Open circuit voltage. of the cells declined significantly with time and end-of-charge voltages were low, indicating the presence of shorts. 


\section{ENERGY RESEARCH CORPORATION}

\subsection{CELLS WITH Ag-HgO RECOMBINATION ELECTRODE PARTITIONS}

A major problem in developing sealed $\mathrm{Ni}-\mathrm{Zn}$ cells has been their poor performance in the electrolyte starved condition. (The cells are run starved to allow oxygen transport for recombination.) One approach to this problem is running the cell pack flooded, with auxiliary electrodes used for the oxygen recombination reaction. A design was evolved in which AgHgo recombination electrodes were run along the sides of the cell pack with one side" wet by electrolyte and the other side exposed to the cell gas. The side of the electrode exposed to gas is laminated with a layer of 2 mil unsintered Teflon film to prevent flooding of the electrode. A diagram of the cell is shown in Figure IV.2.

The first cell built with this design, cell 2R-5, contained $2 \%$ CdO $+1 \%$ Pbo zinc additive and 3 layers of PVA separator. Pellon was used as the electrode absorber wrap.

initial performance of the celi wis very good. Vented. capacity was 19.7 Ah after a 24 Ah charge. Figure IV.3 shows the pressure $r i s e$ ard recombination current on the first sealed charge. After 30.3 Ah of charge the cell was 4 in. of Hg below atmospheric pressure (the cell was at 25 in. $\mathrm{Hg}$ vacuum at the start of charge). Discharge capacity of the cell was 21.2 A..

The recombination current on charge is a measure of the positive electrode charge ettjciency at any point during the charge. It represents the proportion of the charge current lost in oxygen production at the positive electrode. Figure IV. 4 shows the charge efficiency. curve for cell 2R-5, with efficiency ćalculated as: 


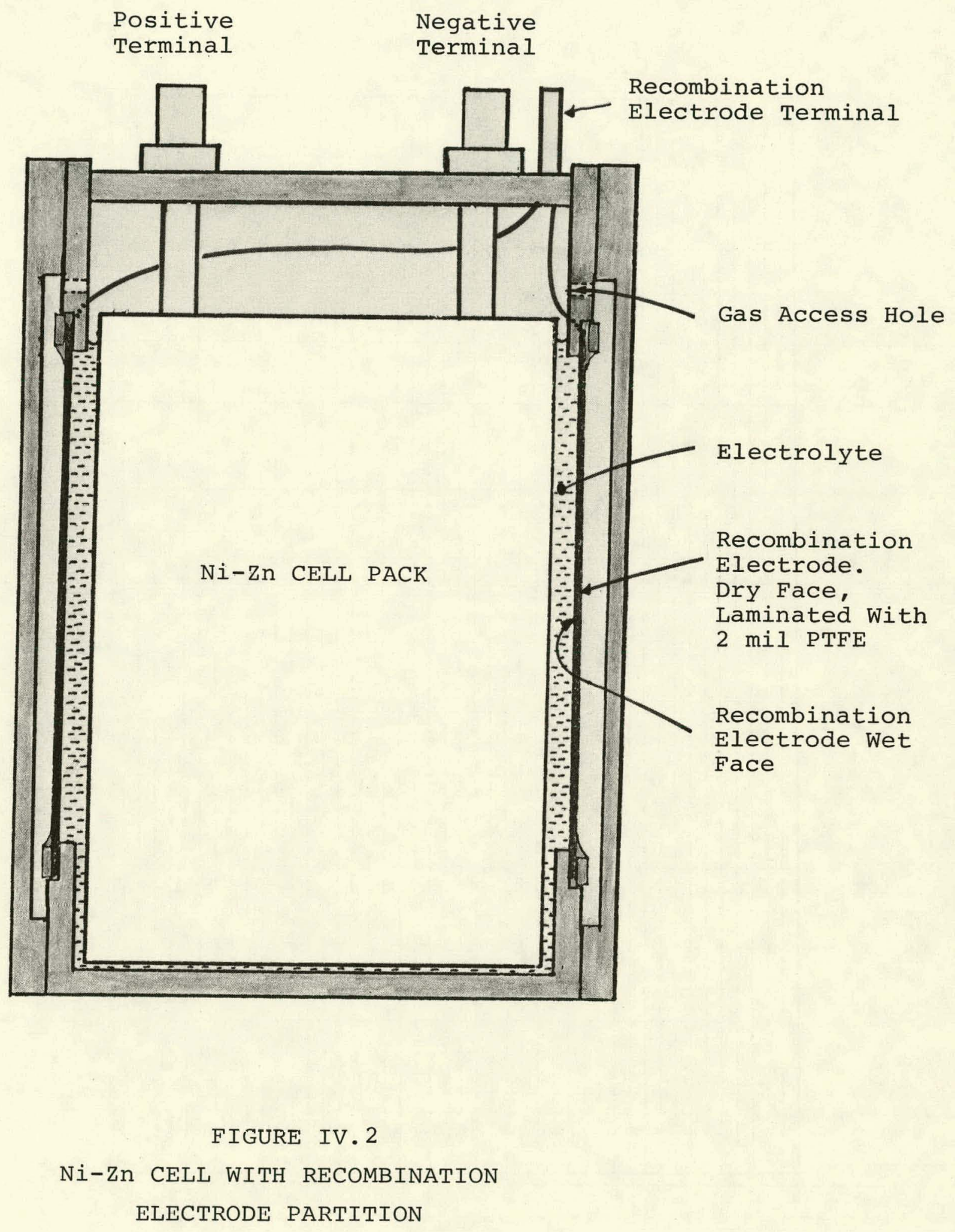

Page No. 167 


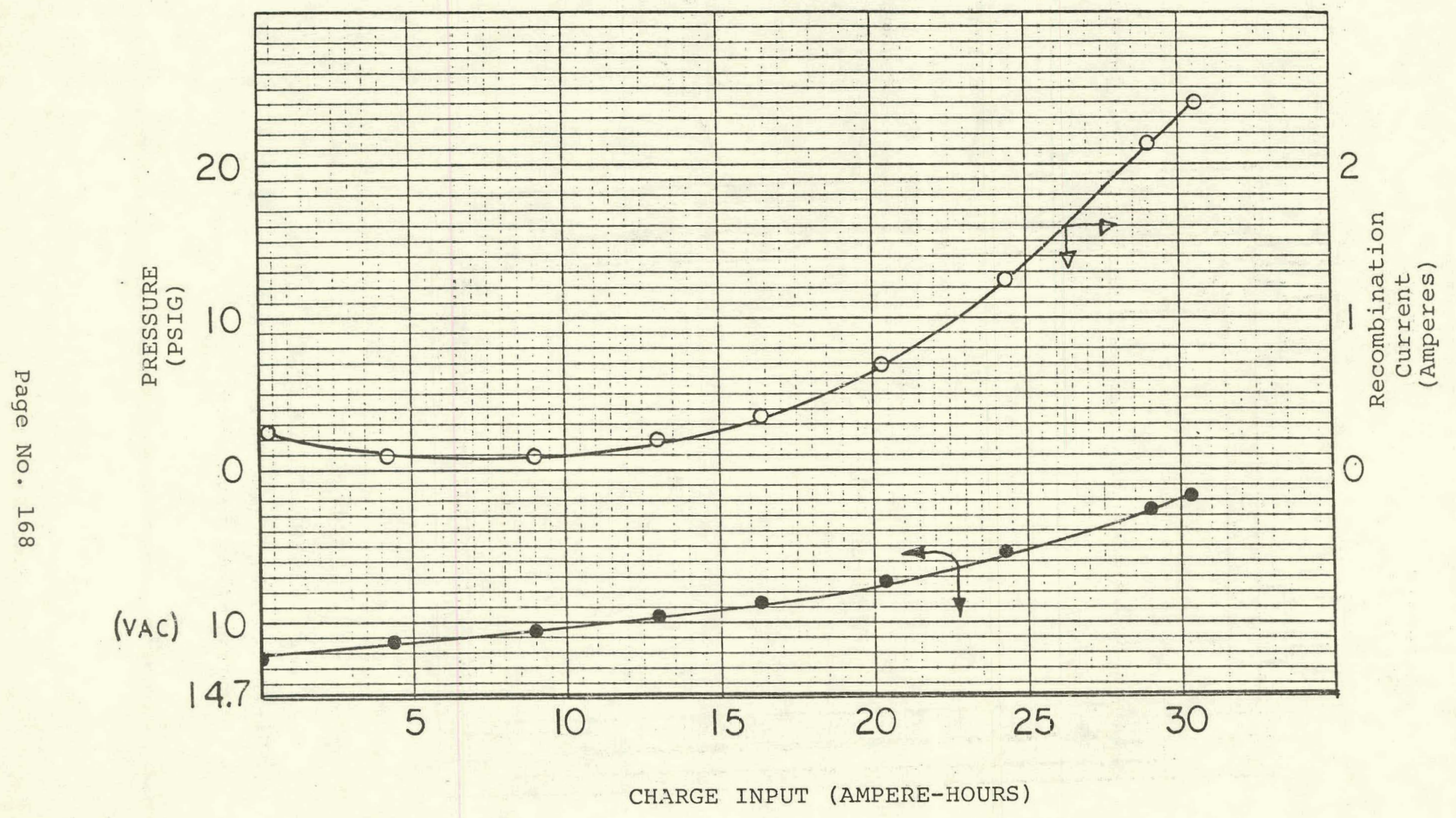

FIGURE IJ.3 PRESSURE AND RECOMBINATION CURRENT CN 4A CHARGE FOR CËLL 2R-5. 
CHARGE

EFFICIENCY

(PERCENT)

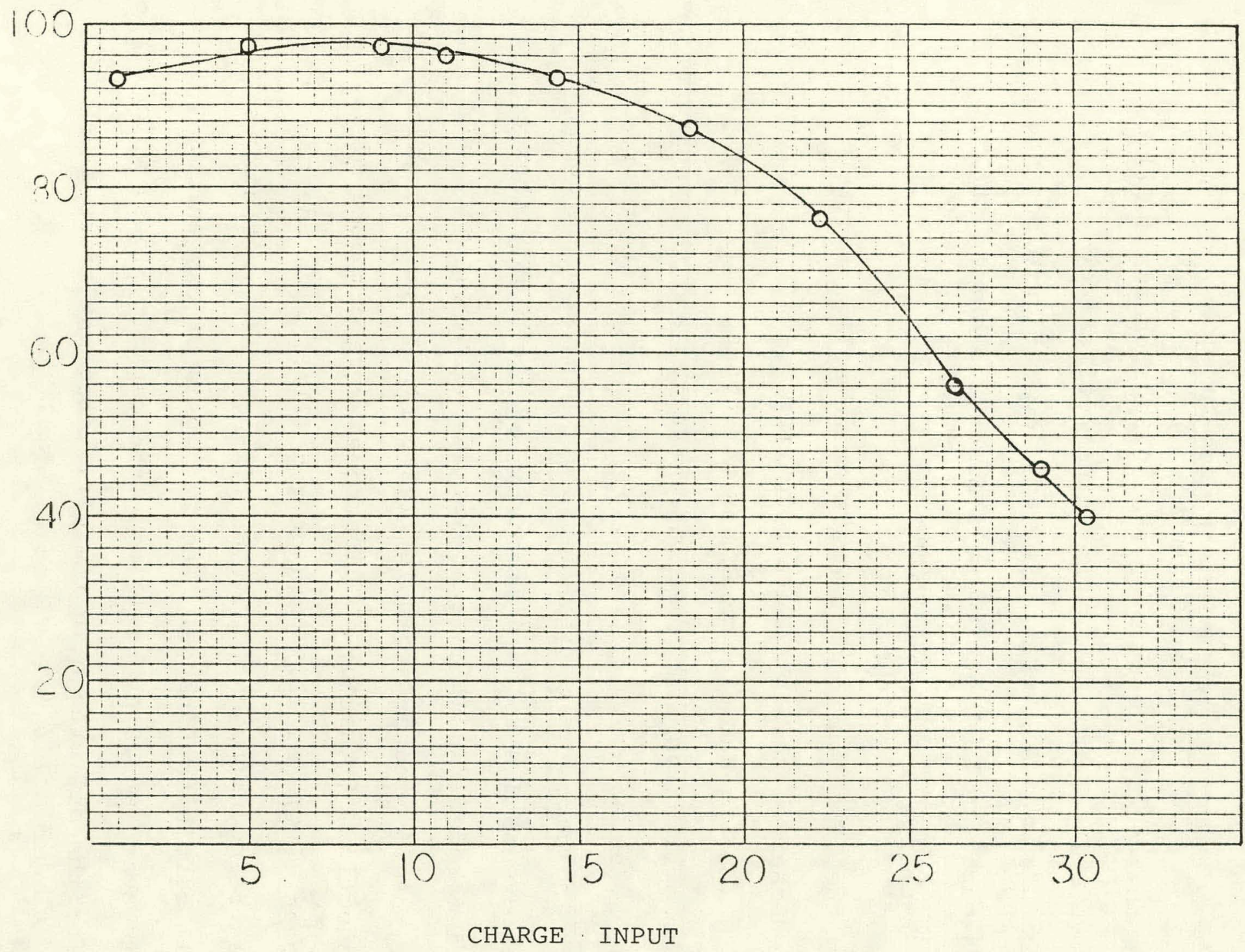

FIGURE IV. 4 CHARGE EFFICIENCY ON CHARGE FOR CELL 2R-5 (BASED ON $\mathrm{O}_{2}$ RECOMBINATION CURRENT) 
Charge Efficiency $=\frac{\text { Charge Current }- \text { Recombination Current }}{\text { Charge Current }}$

The average charge efficiency over the $30.3 \mathrm{AH}$ charge (Cell S-1-2 in Figure IV.1) was $83 \%$. The actual efficiency ( $\frac{\text { discharge capacity }}{\text { charge input }}$ ) was $70 \%$. This is a lower figure because it includes capacity lost due to self-discharge during the time between charge and discharge.

During the 15.6 hour open circuit stand following the first sealed charge, cell pressure rose from a 4 in. Hg vacuum to 18.5 psig (the Ag-Hgo electrode was not connected). At this point the recombination electrode was connected and the pressure began to decay as shown in Figure IV.5. The high rate of recombination indicates that much of the gas generated on open circuit was oxygen due to self-discharge of the highly charged positive electrode. Assuming that all of the oxygen was consumed over the 45 minutes shown in Figure IV.5, the cell gases, hefore connection of the Ag-Hgo electrode, were composed of 7.25 psia hydrogen (22\%) and 23.5 psia oxygen (71\%), with the remaining gas being nitrogen from the 2.49 psia of air that was in the cell before the charge. The 23.5 psia of oxygen corresponds to about a 3.5 Ah positive plate capacity loss, which accounts for the difference in the efficiency estimates discussed above.

The results shown in Figure IV. 5 were used to determine the dependence of recombination current on oxygen partial pressure. This relationship, shown in Figure IV.6, appears to be linear, with some limiting of the reaction rate occurring above 6 amps. 
CURRENT

(AMPERES)

to

เ)

긍

๒

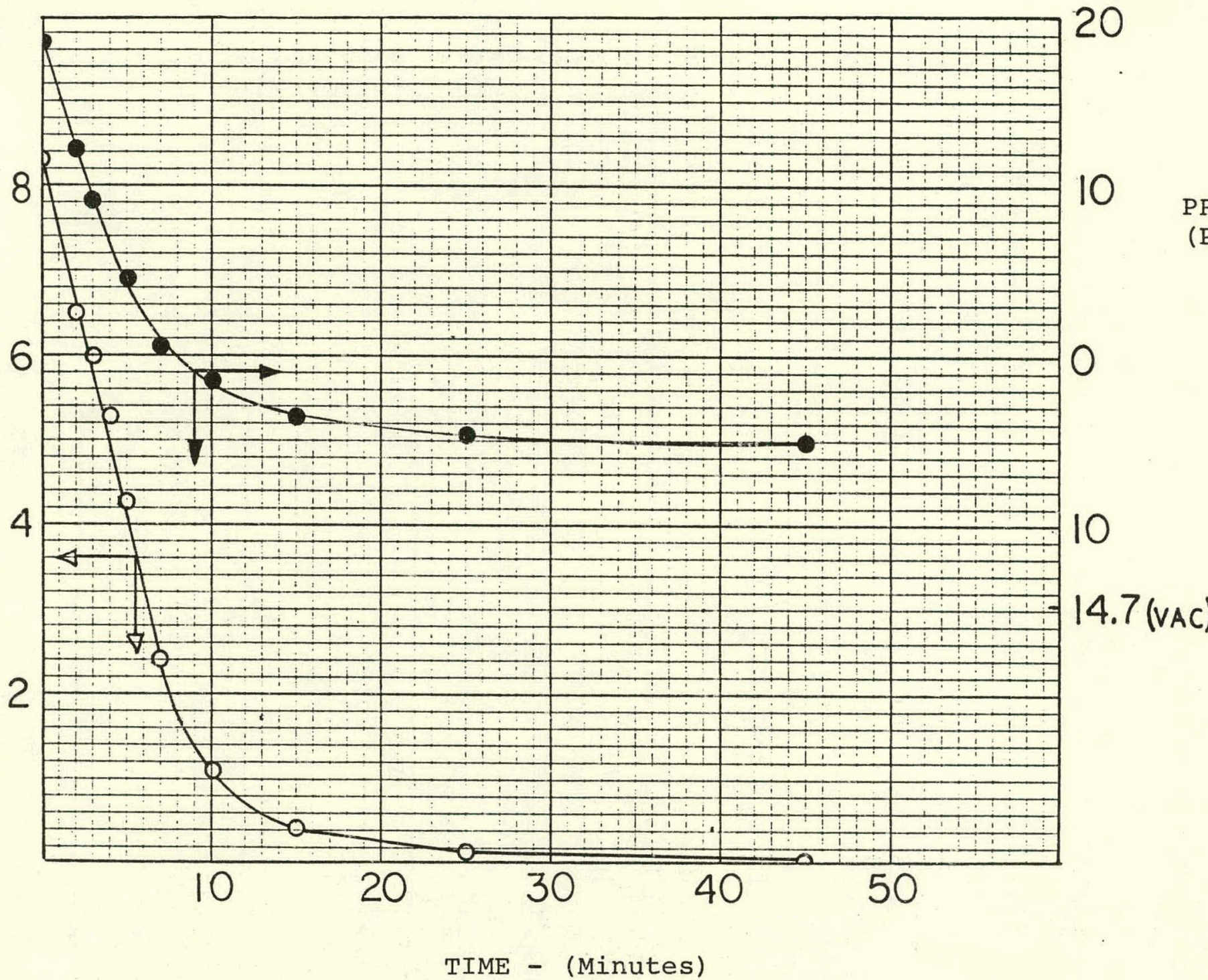

FIGURE IV.5 OPEN CIRCUIT OXYGEN RECOMBINATION FOR CELL 2R-5
PRESSURE

(PSIG) 


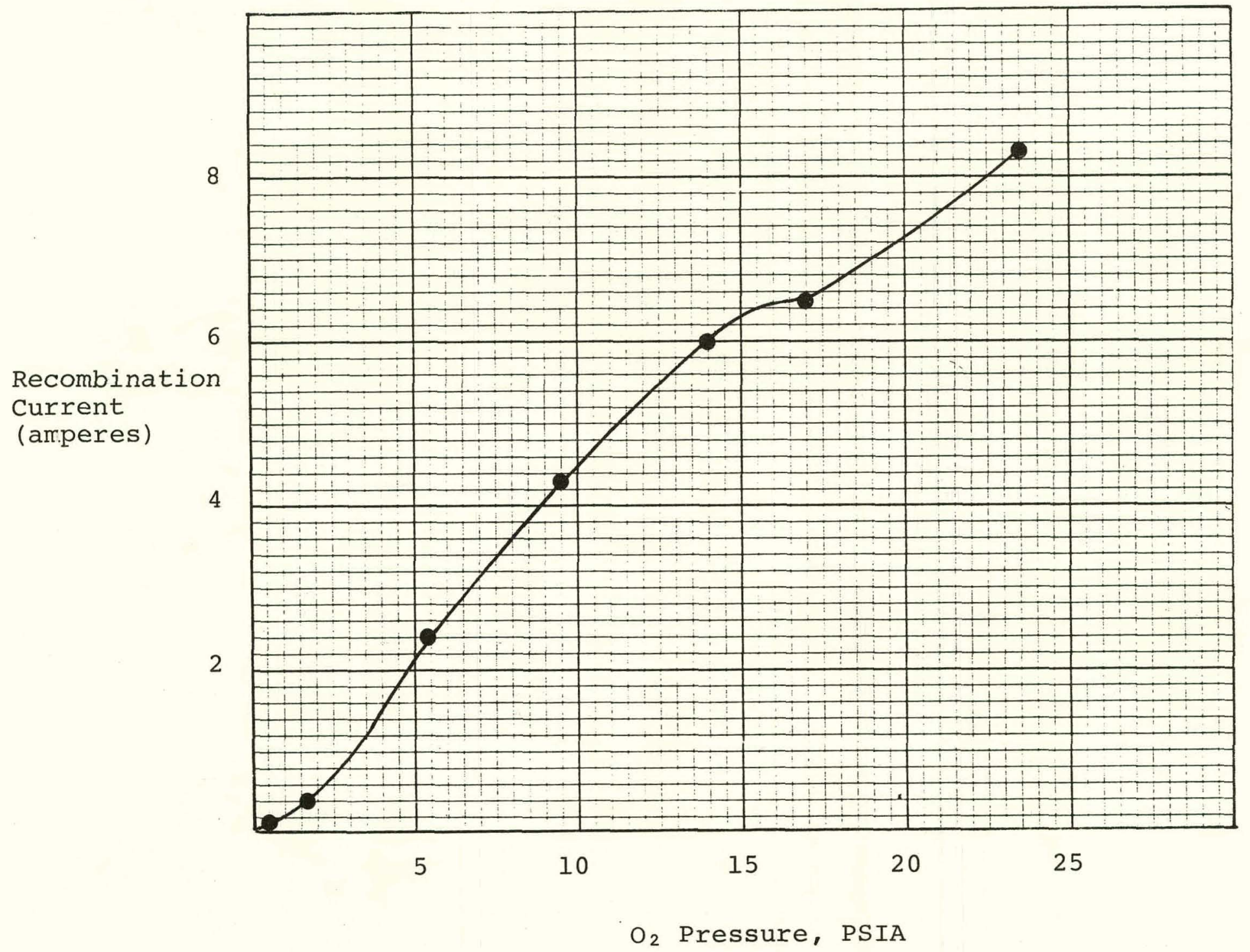

FIGURE IV. 6

RELATIONSHIP BETWEEN RECOMBINATION RATE AND OXYGEA PRFSSURE DURING OPEN CIRCUIT RECOMBINATION, CELL 2R-5 
While initial pressure behavior and discharge capacity were good, performance declined with cycling. The cell was cycle tested with pressure switches set to terminate charge at 20 psig. Platinum catalyst packets were used in the cell to prevent hydrogen build up. The cycling results were as follows:

\begin{tabular}{|c|c|c|c|}
\hline $\begin{array}{c}\text { Charge } \\
\text { Number }\end{array}$ & $\begin{array}{c}\text { Charge Input } \\
\text { To 20 psi, Ah }\end{array}$ & $\begin{array}{r}\text { End-of-Charge } \\
\text { Voltage, Volts }\end{array}$ & $\begin{array}{c}\text { Discharge Capacity } \\
\text { to 1.25V, Ah }\end{array}$ \\
\hline 1 & 22.0 & 1.89 & 15.0 \\
3 & 19.5 & 1.80 & 10.0 \\
5 & 22.0 & 1.87 & 13.1 \\
7 & 14.5 & 2.05 & 10.0 \\
8 & 12.8 & 2.10 & 9.4 \\
9 & 11.0 & 2.12 & 8.1 \\
\hline
\end{tabular}

Following the cycle test, the cell was. given a vented 24 Ah. charge. Discharge capacity was $16 \mathrm{Ah}$.

The cell was dissected to determine why capacity had fallen so quickly. The separator material was generally in good condition although the PVA at the electrode edges was wrinkled and darkened due to occasional high current densities and high temperatures near the Ag-Hgo electrode. Very little zinc penetration was found; however the zinc electrodes exhibited severe shape change. Shape change appears to be accelerated by the recombination electrodes, which discharge the zinc electrode non-uniformly at the edges to a greater extent than the inner portion of the electrode.

Design modifications were made to allow more uniform utilization of the zinc electrode. In one design, the zno 


\section{ENERGY RESEARCH CORPORATION}

active material at the electrode edges was replaced by strips of cdo electrode material, shifting much of the recombination discharge to an insoluble active material. Another approach involved replacing the PVA separator system with Celgard materials with more open pore structures, allowing greater mass transport of electrolyte to the inner portion of the cell pack. rithe Celgard/Pelion system and the 3 layer $\mathrm{K}-306$ separator system were user.

Cell 2R-6 was built with the Celgard/Pellon system and electrode designs identical to Cell 2R-5. Cell 2R-7 contained the same electrode formulations and a separator system consisting of 3 layers of $\mathrm{k}-306$ with an extra layer of Pellon absorber inserted between two of the layers. Woven nylon was used as the positive plate wrap in both cells to allow room for the extra fellon layers. Cell 2R-8 contained the same separator system as cell 2R-5 ( 3 layers PVA) but was built with zinc electrodes in which $1 / 2$ inch strips on each side had been replaced with active material composed of $94 \% \mathrm{CdO}, 5 \%$. Ag powder and $1 \%$ Teflon binder. Data for these cells on vented formation cycles are given in Table IV.3.

Discharge capacities for Cell 2R-6 were low: Dissection analysis indicated that much of the Celgard had not wet and zinc penetration was severe in the areas that had wet. Failure of the cell was due to the poor wetting of the $3500 \mathrm{film}$ (earlier cells with the Celgard/Pellon system were built with 3401 , which contains an improved wetting agent).

Cells $2 \mathrm{R}-7$ and $2 \mathrm{R}-8$ were cycle tested with relief valves set to vent at $30 \mathrm{psig}$. The cells were charged at 4 amps for 


\begin{tabular}{|c|c|c|c|c|c|c|}
\hline \multirow[b]{2}{*}{ CELL NO. } & \multirow[b]{2}{*}{ DESIGN FEATURES } & \multicolumn{2}{|c|}{ FIRST CYCLE } & \multicolumn{2}{|c|}{ SECOND CYCLE } & \multirow[b]{2}{*}{$\begin{array}{l}\text { Discharge } \\
\text { Midpoint } \\
\text { Voltage }\end{array}$} \\
\hline & & $\begin{array}{l}\text { End of } \\
\text { Charge } \\
\text { Voltage }\end{array}$ & $\begin{array}{l}\text { Discharge } \\
\text { Capacity } \\
\text { to } 1.25 \mathrm{~V}\end{array}$ & $\begin{array}{l}\text { End of } \\
\text { Charge } \\
\text { Voltage }\end{array}$ & $\begin{array}{l}\text { Discharge } \\
\text { Capacity } \\
\text { to } 1.25 \mathrm{~V}\end{array}$ & \\
\hline $2 \mathrm{R}-6$ & $\begin{array}{l}\text { Celgard } \\
\text { Separator: Nyion/3400/Pellon/2xCelgard/Pellon/Celgard///Pellon } \\
28 \text { Cdo + } 18 \text { Pbo additive }\end{array}$ & 1.987 & 6.8 & 1.984 & 8.2 & 1.32 \\
\hline $2 R-7$ & $\begin{array}{l}\text { (+) Nylon } / 2 \times 306 / \text { Pellon } / K-3.06 / / \text { Pellon }(-) \\
28 . \text { Cdo }+18 \text { PbO additive }\end{array}$ & 1.865 & 20.2 & 1.895 & 24.0 & 1.59 \\
\hline $2 R-8$ & $\begin{array}{l}\text { (+) Pellon/2PVA///1PVA/Pellon (-) } \\
28 \mathrm{CdO}+18 \mathrm{PbO}+c d \text { strips on electrode edges }\end{array}$ & 1.849 & 5.2 & 1.909 & 16.2 & 1.59 \\
\hline
\end{tabular}

TABLE IV. 3

FORMATION DATA FOR CELLS WITH RECOKBINATION ELECTRODES 


\section{ENERGY RESEARCH CORPORATION}

6 hours and discharged at 10 amps to $1.25 \mathrm{~V}$ for 2 hours. The recombination electrodes were connected to the negative electrode through a shunt resistor, through which current readings could be taken. Cycling results for these cells are given in Table IV. 4. The pressure, voltage and recombination current monitored during Cycle 7 are shown in Figures IV. 7 and IV.8. It is apparent in both cells that recombination current reaches a maximum and then arops as the relief valve vents and oxygen partial pressure decreases (due to increasing rates of hydrogen generation). In Cell 2R-7, recombination current reached a maximum of 3.8 amps, or $95 \%$ of the charge current. In cell 2R-8, recombination current reached a maximum of only 2.2 amps, or $55 \%$ of charge current. This difference in recombination current, an indication of positive electrode efficiency, is consistent with the discharge capacity data.

prior to being placed on automatic cycle, cell $2 \mathrm{R}-7$ was tested to determine the characteristics of the recombination electrodes. The cell was vacuumed and then filled with various pressures of pure oxygen. Pressure was maintained by a regulator, which continuously fed oxygen to the cell. The readings at higher pressures were taken first. Equilibrium current values were reached fairly quickly (within two minutes) at each pressure. Figure IV.9 shows a linear relationship between reaction rate and $\mathrm{O}_{2}$ pressure up to about 21 psia 16.3 psig), where current becomes limited. Because this test involved sustained reaction rates, the current values are lower than in Figures IV.5 and IV.6 (with Cell 2R-5). The limitations in recombination rate seen in Figures IV.6 and IV.9 
TABLE IV. 4

Cycle Performance of Sealed Cells with Recombination Filectrodes

\begin{tabular}{|c|c|c|c|c|}
\hline \multirow[b]{2}{*}{ Cycle \# } & \multicolumn{2}{|c|}{ CEIL 2R7 } & \multicolumn{2}{|r|}{ CELL 2R8 } \\
\hline & $\begin{array}{l}\text { End of } \\
\text { Charge } \\
\text { Voltage }\end{array}$ & $\begin{array}{l}\text { Discharge } \\
\text { Capacity } \\
\text { To } 1.25 \mathrm{~V}\end{array}$ & $\begin{array}{l}\text { End of } \\
\text { Charge } \\
\text { Voltage }\end{array}$ & $\begin{array}{l}\text { Discharge } \\
\text { Capacity } \\
\text { to } 1.25 \mathrm{~V}\end{array}$ \\
\hline & (Volts) & $\begin{array}{c}\text { (Ampere } \\
\text { Hours) }\end{array}$ & (Volts) & $\begin{array}{c}\text { (Ampere } \\
\text { Hours) }\end{array}$ \\
\hline 3 & 1.90 & 18.1 & 1.91 & 18.0 \\
\hline 5 & 1.89 & 14.4 & 1.89 & 14.8 \\
\hline 7 & 1.90 & 13.8 & 1.98 & 16.0 \\
\hline 9 & 1.91 & 13.0 & 2.12 & 16.0 \\
\hline 11 & 1.97 & 14.9 & 2.15 & 16.9 \\
\hline 13 & 2.00 & 15.2 & 2.15 & 17.5 \\
\hline 15 & 1.90 & 13.8 & 2.12 & 16.0 \\
\hline 17 & 1.90 & 11.8 & 2.05 & 14.2 \\
\hline 19 & & & 2.00 & 13.2 \\
\hline 21 & & 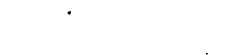 & 1.90 & 11.2 \\
\hline . 23 & & & 1.80 & 8.0 \\
\hline
\end{tabular}

All Charges: 4 Amps $\times 6$ hours

All Discharges: at 10 Amps 


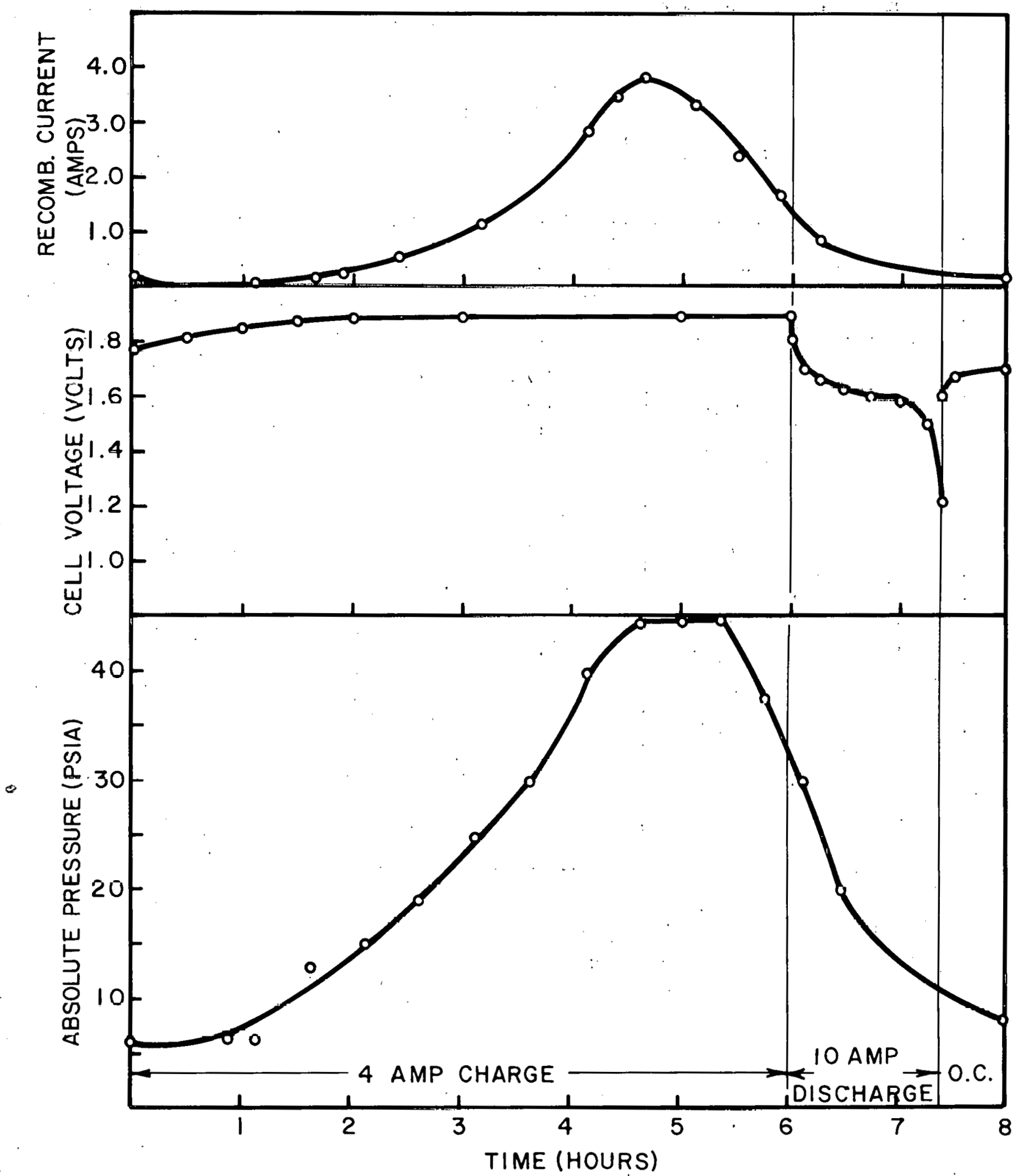

PIGURE IV. 7 PERFORIMNCF OF CELL 2 R7 ON CYCLE

Page No. 178 


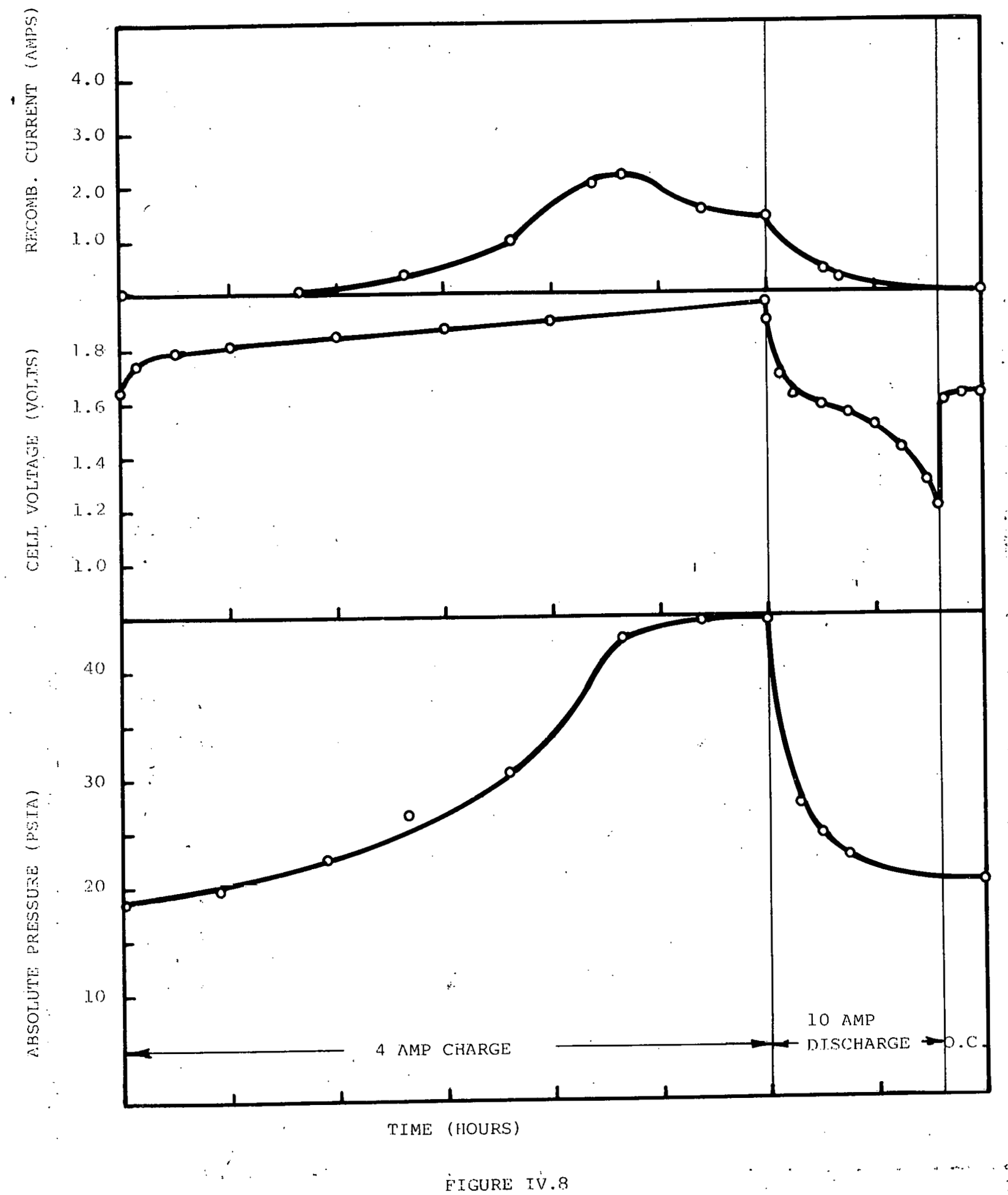

EFRTIORMANCF: OF CFIIJ, 2R8 ON CYCLE \#7

Page No. 179 


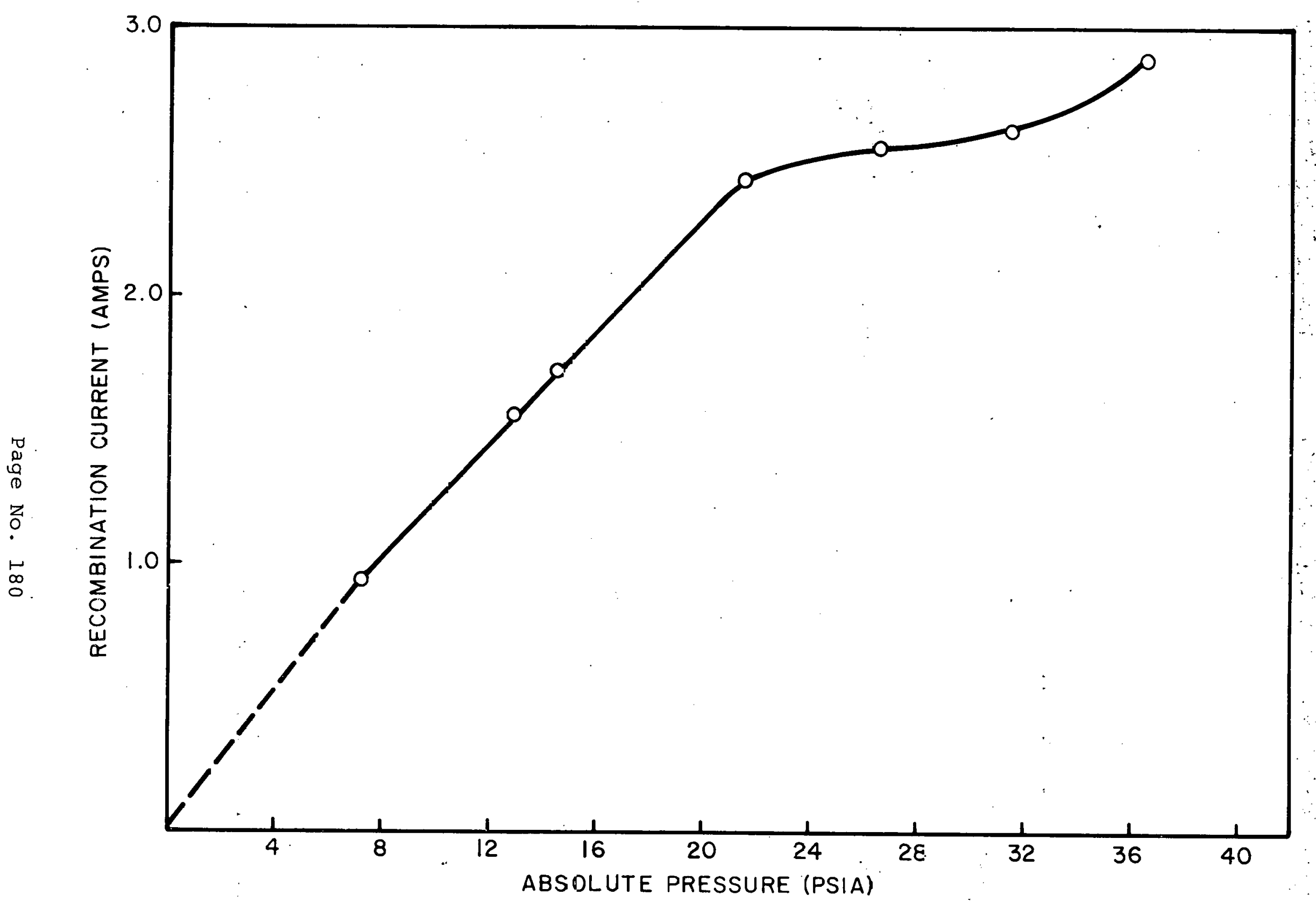

FIGURE IV. 9 CELL ¿R? RECOIMBINATIJN RATE VS $\mathrm{O}_{2}$ PRESSUfE 
are due to limitations in ion transport from the plates through separator wraps to the recombination electrode.

While initial performance of cells $2 R-7$ and $2 R-8$ was good, the data in Table IV.4 show a rapid decline in capacity during cycling, with both cells failing within 20 cycles. Dissection of 2R-7 showed considerable shape change and zinc penetration throughout the center portion of the separator wrap. The separator was wet and had not lost much strength. Zinc had saturated the center portion of the Pelion wrap, which was fused to the plate.

Shape change was also evident in the negative plates in Cell 2R-8, but it was not as severe as in Cells $2 \mathrm{R}-7$ or $2 \mathrm{R}-5$. The cadmium strips were intact and showed a change in color toward the edges, indicating a variation in the state of charge. The PVA separator had oxidized considerably, losing much of its strength and appearing black near the electrode edges. zinc penetration could be seen throughout the separator area covering the zinc portion of the negative plates.

The performance of cells with the recombination electrode partition indicates that the benefits provided by the flooded cell pack may be outweighed by the uneven utilization of the zinc electrode. Cycle test performance in these cells was inferior to cells run electrolyte-starved, where the recombination reaction was more evenly distributed on the zinc electrode. 


\subsection{CONCLUSIONS AND FUTURE WORK}

The potential benefits of the sealed cell configuration have not yet been realized in Ni-Zn cells. The two best sealed cell designs (containing Celgard/Pelion or coated Celgard separator systems) are Iimited to about 30 cycles. This result has been achieved in cells with charge-terminating pressure switches as well as cells with relief valves which allow a full charge input.

The predominant failure mechanism in the cells is dryout, due to electrolyte redistribution during cycling. One approach to this problem, using the recombination electrode partition, increased the shape change problem by distributing the oxygen recombination reaction unevenly over the zinc electrode to the plate edges.

Another approach is to improve the electrode retention capability of the separator layers, absorber wraps and electrodes. Future work in the sealed cell task should focus on this approach.

Future work should also include evaluation of various electrode constructions, such as split zinc electrodes and low density electrodes that may improve cell wetting. Separator systems combining the K-306 film with membrane dendrite barriers and nickel-coated celgard film should also be evaluated to aetermine if the increased dendrite protection can extend cell life. Because of budget limitations in FY 1981 work in this area will be discontinued. 
ENERGY RESEARCH CORPORATION

SECTION VI

SYSTEM ENGINEERING (TASK V)

Page No. 183 


\section{ENERGY RESEARCH CORPORATION}

\subsection{INTRODUCTION}

The objective of this phase of the ANL nickel-zinc program is the optimization of the $\mathrm{Ni}-\mathrm{Zn}$ electric vehicle battery. Included in the effort are the design and testing of EV type Ni- $\mathrm{nn}$ cells incorporating advances made in component technology, manufacturing methods, and design concepts. The system engineering task also includes the development of charging procedures and charge control techniques.

Three test vehicles have been used to evaluate variations in cell design. Before testing design cuncepls in full-size cells, it is advantageous to have a less expensive, accelerated test to screen experimental designs. Small cells of $20 \mathrm{Ah}$ nominal capacity have been used for this purpose. Because these cells fail to provide information on the scale-up problems encountered in larger culls, more recent teeting has been thne in single electrode test cells. The single electrode cell consists of a full-size positive electrode between two negative plates. The cells provide test data which have been found to be more indicative of large cell performance.

The most promising design concepts are tested in fuld-size cells of 250 Ah nominal capacity. Full-size cells have undergone constant current and constant voltage cycle tests, as weil as J-227D vehicle simulation tests.

This section of the report will present data from 20 Ah full-size, single electrodes and. $250 \mathrm{Ah}$ cells on constant current cycle tests. Results of 250 Ah cells on constant voltage, two step charge and vehicle simulation tests will also be given. 


\subsection{TECHNICAL DISCUSSION}

2.1 TESTING OF 20 AMPERE-HOUR CELLS

Evaluation of various zinc electrodes and electrolytes was performed on 20 Ah nickel-zinc cells. The cells consisted of six pairs of $3-7 / 8 \times 2-7 / 8$ in. electrodes. The separator design ased in the cells was as follows:

\section{(+) Nylon/ 3 layers PVA/: Pellon (-)}

To accelerate the accumulation of data, the cells were tested on a $100 \%$ cepth of discharge cycle test. The cells were discharged at 10 amps for two hours or until cell voltage dropped to $0.8 \mathrm{~V}$. The cells were charged at 3.67 amps for 6 hours. 2.1.1 Zinc Electrode Tests

A series of 20 Ah cells were built with various additives in the zinc electrode. The results of these tests are given in Table V.l, which lists the cycle life and half life capacity of the cells.

The cell with the longest cycle life was cell 117, with $2 \% \mathrm{PbO}+1 \% \mathrm{O}$ Cdo zinc electrode additive. This cell and the cells with $10 \% \mathrm{Bi}_{2} \mathrm{O}_{3}$ delivered the most capacity while on cycle test (the best of the three cells delivered a maximum of 19.4 Ah at some point in their cycle life).

At the time of these tests, the $10 \% \mathrm{Bi}_{2} \mathrm{O}_{3}$ additive was the baseline zinc electrode formulation. Cells were built with lower and higher concentrations of $\mathrm{Bi}_{2} \mathrm{O}_{3}$ and cycle tested. The results, given in Figure V. 1, show an improvement in performance with higher concentrations of $\mathrm{Bi}_{2} \mathrm{O}_{3}$ in the negative plate. The 
TABLE V.1

EVALUATTGN OF ZINC ELECTRODE ADDITIVES IN

$20 \mathrm{AH} \mathrm{Ni-Zn} \mathrm{CELLS}$

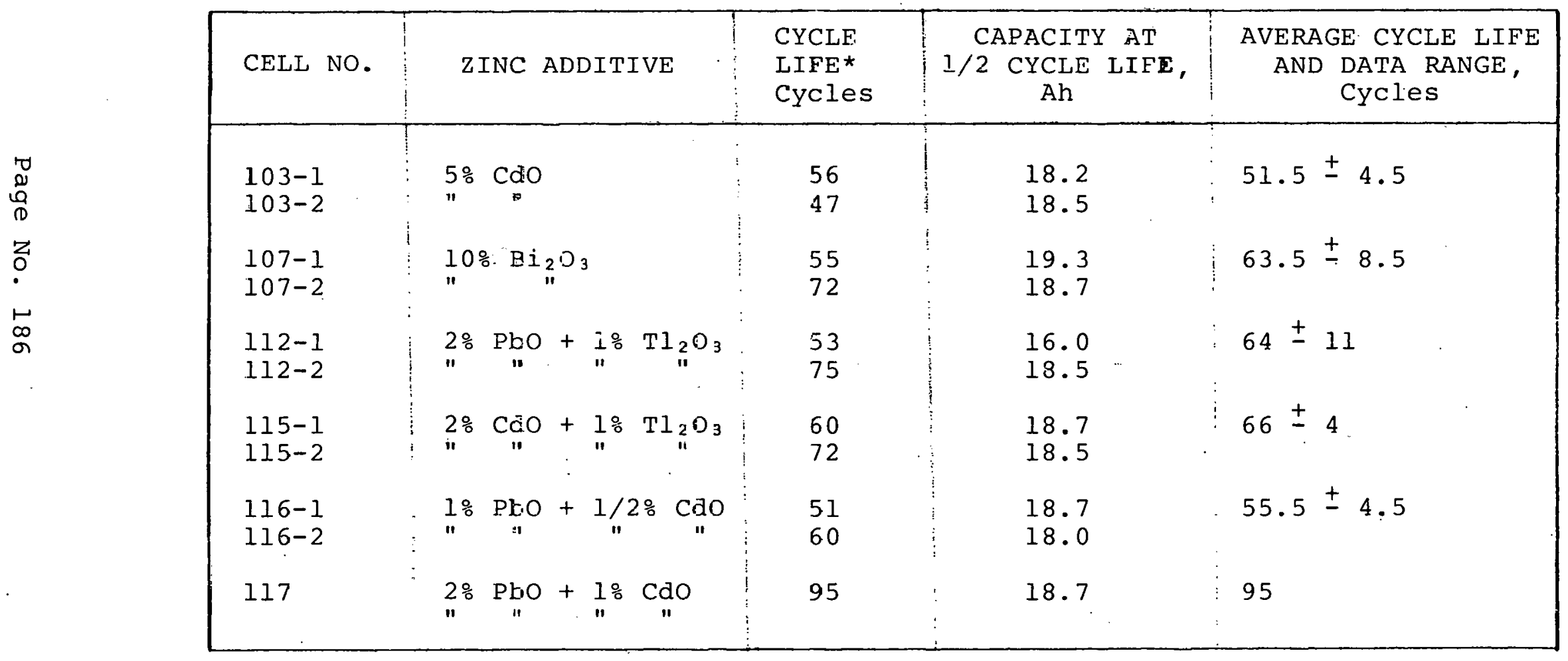

* Number of cycles a cell rar before capacity fell to $12 \mathrm{Ah}$. 


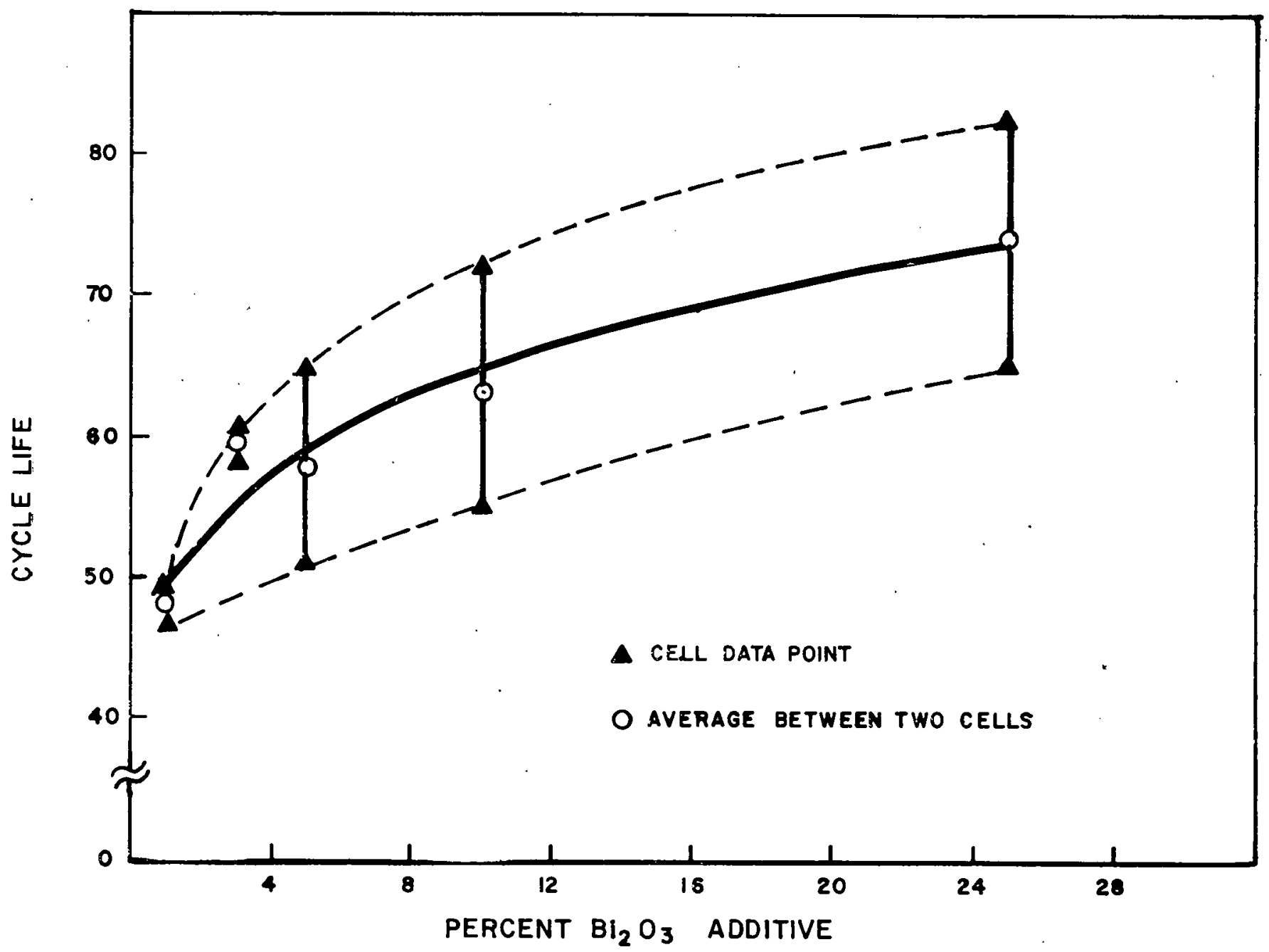

FIGURE V.I

CYCLE PERFORMANCE OF CELLS WITH $\mathrm{Bi}_{2} \mathrm{O}_{3}$ ADDITIVE 


\section{ENERGY RESEARCH CORPORATION}

improvement in performance is most pronounced below the 3\% level. Above this level, cycle life continues to improve with increased $\mathrm{Bi}_{2} \mathrm{O}_{3}$ concentration, but at a diminishing rate. Despite this, the cells with $25 \% \mathrm{Bi}_{2} \mathrm{O}_{3}$ did not cycle as well as the cell with $2 \% \mathrm{PbO} / 1 \% \mathrm{CdO}$ additive.

An experimental zinc plate with an electrode mix consisting of $1.25 \%$ filler $+93.75 \% \mathrm{ZnO}$ was tèsted in $20 \mathrm{Ah}$ cells. The mix was heat-treated at $900^{\circ} \mathrm{C}$ for 4 hours before being mixed with a binder ( $2 \%$ Teflon) and made into electrodes. Figure V.2 compares the cycle data of this cell with a control cell containing $10 \% \mathrm{Bi}_{2} \mathrm{O}_{3}$ additive.

The results show that while initial capacity for the cell with heat-treated zno was low, this eventually jmproved and cycle life was finally greater than for the control cell. However, additional testing of this mix in larger cells did not produce good results. This may have been due to reduced resistance of the heat-treated material to the pressures in the larger cell pack.

To evaluate the effect of scale-up on the performance of various cell designs, more recent testing of $z 1$ nc electrude variabiles has been done in the full-size, single electrode test cells described in section 2.2 .

\subsubsection{Investigation of Alternate Electrolytes}

A series of $20 \mathrm{hi}$ cells were built for the evaluation of various electrolytes. The standard electrolyte consists of an. aqueous solution ( $35 \% \mathrm{KOH}$ and $1 \% \mathrm{Li}(\mathrm{OH})$ by weight). Two electrolytes with reduced zinc solubility were tested: one with $20 \%$ $\mathrm{KOH}$ and $1 \% \mathrm{Li}(\mathrm{OH})$ and another with $35 \% \mathrm{KOH}$, and $1 \% \mathrm{LiOH}$, and $6 \%$ 


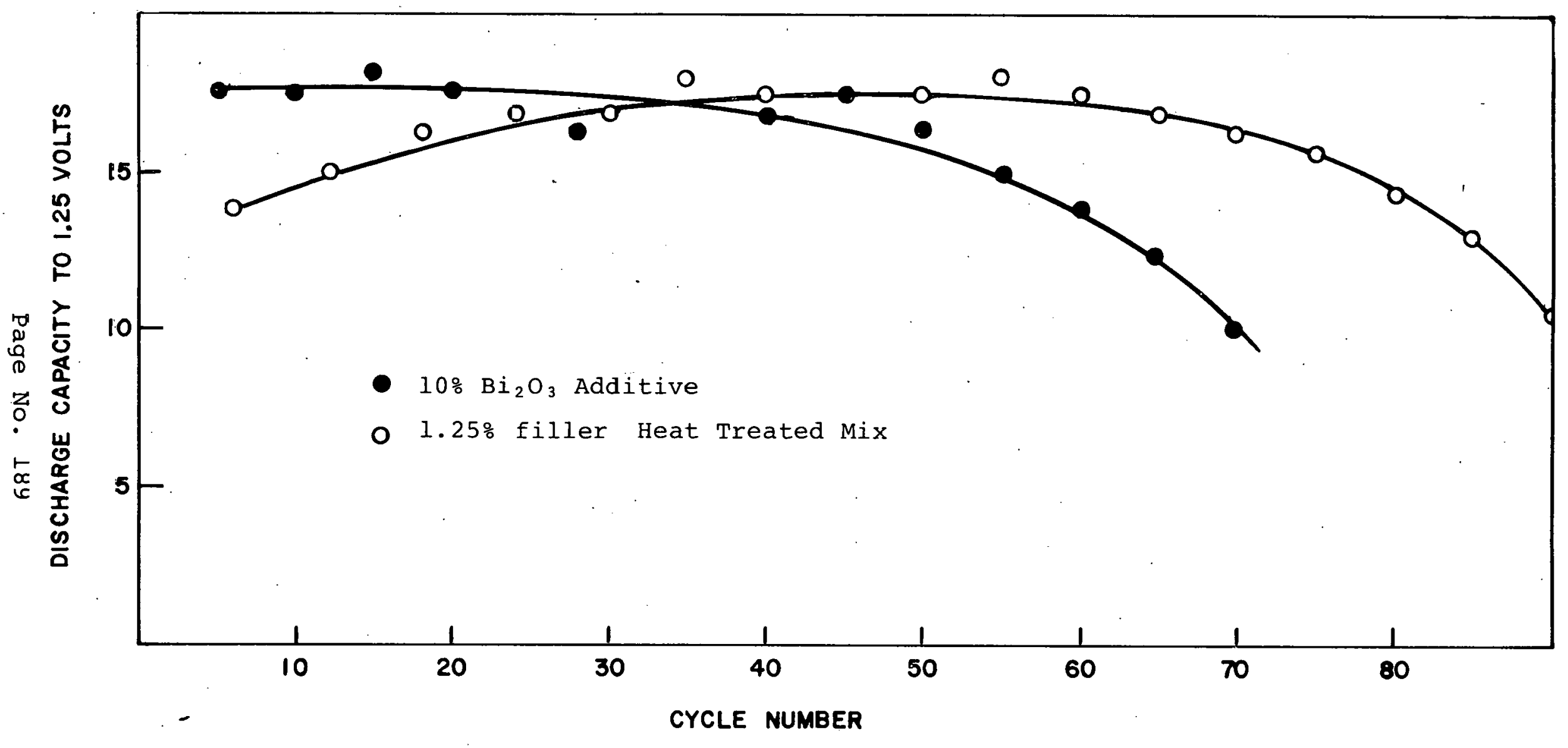

FIGURE V.?

CYCLTNG: HEAT-TREATED ZnO 


\section{ENERGY RESEARCH CORPORATION}

boric acid. An electrolyte with a higher concentration of $\mathrm{KOH}$ (45\%) was used to determine if a higher utilization of the positive electrode could be achieved. The potential disadvantage of these electrolytes is that the lower $\mathrm{KOH}$ concentration may increase zinc degradation while the higher KOH concentration may increase zinc dissolution and shape change. A fifth electrolyte that was tested consisted of a plating agent added to $35 \% \mathrm{KOH}$ in an attempt to reduce the formation of dendritic zinc.

The results of this test, given in Table V.2, indicate a superiority of the bromide salt additive. The $20 \% \mathrm{KOH}$ and borate electrolytes did show improved cycle life over the cell with standard electrolyte, but with lower initial capacity due to reduced concentration of hydroxyl ions. The $45 \% \mathrm{KOH}$ showed good initial capacity but shorter cycle life than the $20 \%$ KOH or borate electrolytes.

These tests were performed on cells with a PVA separator and $\mathrm{Bi}_{2} \mathrm{O}_{3}$ zinc additive. The current effort in this program task has centered on the evolution of a new baseline design with a $\mathrm{Pbo} / \mathrm{CdO}$ additive to the zinc electrode and coated celgard separator. While the $35 \% \mathrm{KOH}+1 \% \mathrm{LiOH}$ has remained the standard electrolyte, future plans call for re-evaluating alternate electrolytes in the newer type cells.

2.2 FULL-SIZE, SINGLE ELECTRODE TESTS

One disadvantage of the $20 \mathrm{Ah}$ cell tests is that the results obtained provide no information on scale-up problems. As a result, many design variations which perform well in 20 Ah cells perform poorly when used in 250 Ah cells. A full-size, single electrode test was developed to provide rapid information while 
TABLE V. 2

ALTERNATE ELECTROLYTE MIXES IN 20 AH Ni-Zn CELLS

\begin{tabular}{|c|c|c|c|c|c|c|c|c|}
\hline & \multicolumn{8}{|c|}{ CELL NO. } \\
\hline & 1 & 2 & 3 & 4 & 5 & 6 & 7 & 8 \\
\hline$\therefore$ & \multicolumn{8}{|c|}{ ELECTROLYTTE } \\
\hline & $\begin{array}{l}35 \% . \mathrm{KOH} \\
\text { (STD.) } \\
\end{array}$ & \multicolumn{2}{|c|}{$20 \% \mathrm{KOH}$} & \multicolumn{2}{|c|}{$45 \% \mathrm{KOH}$} & \multicolumn{2}{|c|}{$\begin{array}{l}35 \% \text { KOH } \\
6 \% \text { Boric Acid }\end{array}$} & $\begin{array}{l}35 \% \text { KOH }+.01 \text { Molar } \\
\text { Tetrabuty } \\
\text { Ammonium Bromide }\end{array}$ \\
\hline$\frac{\text { CYCLE \# }}{5}$ & $>20$ & 17.5 & 20.0 & $>20.0$ & $>20.0$ & 15.0 & 15.0 & $>20.0$ \\
\hline 15 . & 17.5 & 16.8 & 15.0 & $>20.0$ & $>20.0$ & 16.8 & 16.8 & 20.0 \\
\hline 25 & 17.5 & 15.0 & 15.0 & 18.8 & 20.0 & 17.5 & 17.5 & 17.5 \\
\hline 35 & 17.5 & 15.0 & 15.0 & 17.5 & 17.5 & 16.3 & 16.8 & 18.0 \\
\hline 45 & 13.0 & 15.0 & 15.0 & 16.5 & 17.5 & 15.0 & 15.0 & 18.0 \\
\hline 50 & $12.5^{\circ}$ & 15.0 & 15.0 & 16.3 & 16.3 & 15.0 & $15.6^{\circ}$ & 16.9 \\
\hline 60 & -- & 15.0 & 15.0 & 13.8 & 13.8 & 15.0 & No data & 15.0 \\
\hline 70 & -- & 15.0 & 15.0 & 11.3 & 11.3 & 13.1 & 13.1 & 15.0 \\
\hline 85 & -- & 13.8 & 13.8 & -- & -- & 12.0 & 11.9 & 12.5 \\
\hline 95 & -- & 11.9 & 11.9 & -- & -- & -- & -- & 12.0 \\
\hline
\end{tabular}


addressing the problems of scale-up in fabricating 250 Ah cells. The test involves cycling one set of 250 Ah size electrodes in a reusable test fixture. One positive plate is placed between two negative plates. In the first cells tested, two zinc half plates were used. Performance of these cells was poor and it was found that the cells would be more indicative of $250 \mathrm{Ah}$ performance if full-size electrodes were used. In this configuration, the zinc active material on the outer side of the copper collector is not utilized. A comparison of the PVA separator/ $\mathrm{Bi}_{2} \mathrm{O}_{3}$ additive design in four different test vehicles is shown in Figure V.3.

The single electrode test has been used to evaluate variations in zinc electrode and separator design. The cells, which have a theoretical capacity of $24.3 \mathrm{Ah}$, are tested on the $20 \mathrm{Ah}$ test regime described abojé, with thie dulomatic voltagc out-off raised from 0.80 to $1.25 \mathrm{~V}$. Design evaluations conducted in the single electrode test have led to significant improvements in 250 Ah cell design.

2.2.1 Evaluation of Zinc Electrode Designs

The zinc electrode studies in single electrode cells have centered on finding a zinc design with good electrochemical properties and sufficient mechanical strength to resist compression from the expanding positive plate.

Table V.3 gives the cycle data for 5 cells with PVA separator and various zinc electrode designs. In addition to the heat-treated $\mathrm{mix}$ and binary additives which were tested in $20 \mathrm{Ah}$ cells, a single electrode cell was built with Pbo/Cdo additive and 5\% potassium-titantate (KT). The KT was added to the zinc 


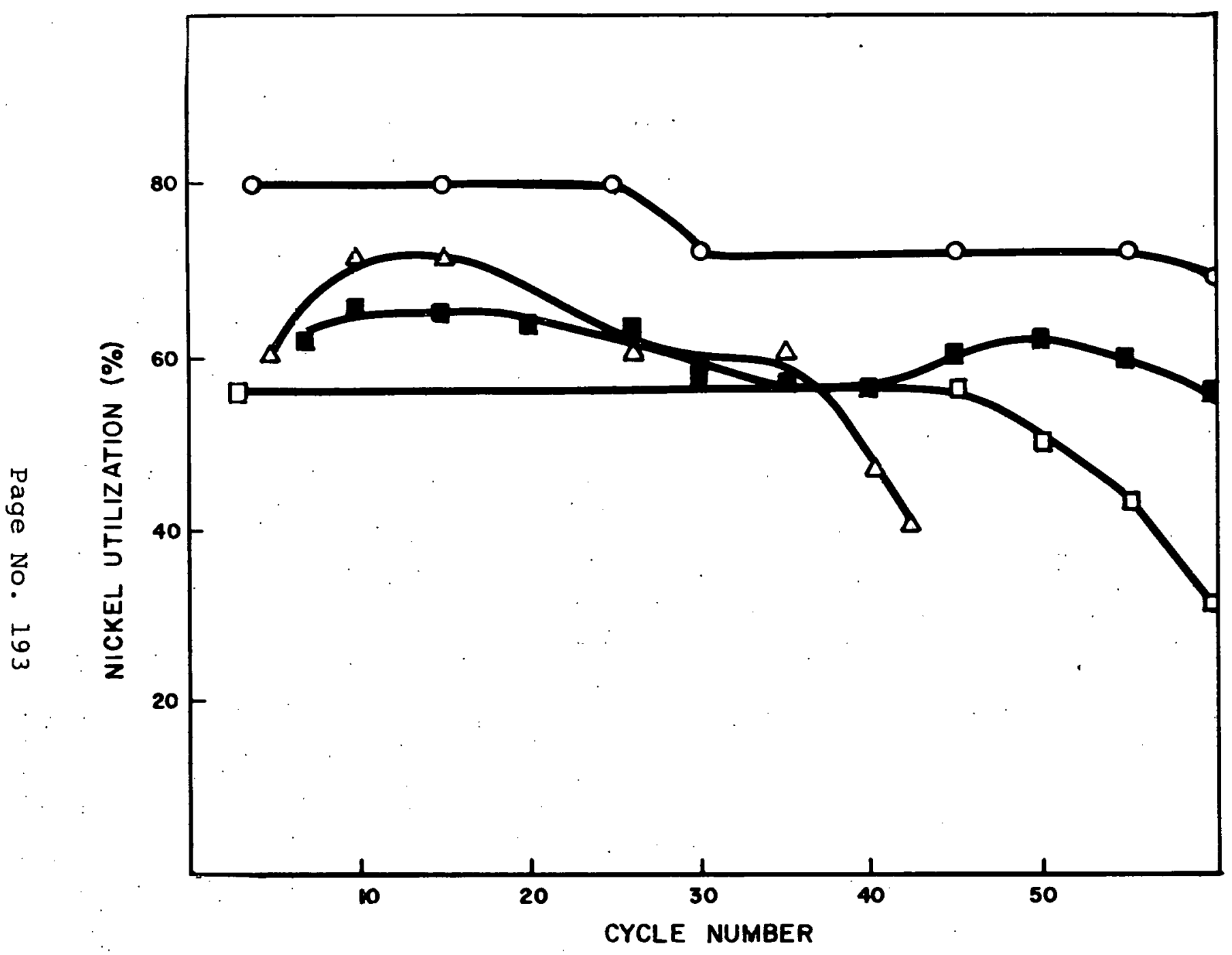

EV Cell - Theoretical Cap. $340 \mathrm{Ah}$

- 20 Ah Cell - Theoretical Cap. $25.1 \mathrm{Ah}$

- Single Electrode Cell with Half-Plate Zinc Electrodes Theoretical Cap. 24.3 Ah

Single Electrode Cell with Full Zinc Plates

Theoretical Cap. 24.3 Ah

FIGURE V. 3

STANDARD Ni-Zn DEISGN IN

DIFFERENT TEST CELL CONSTRUCTIONS

ALL ON CONSTANT CURRENT CYCLE 


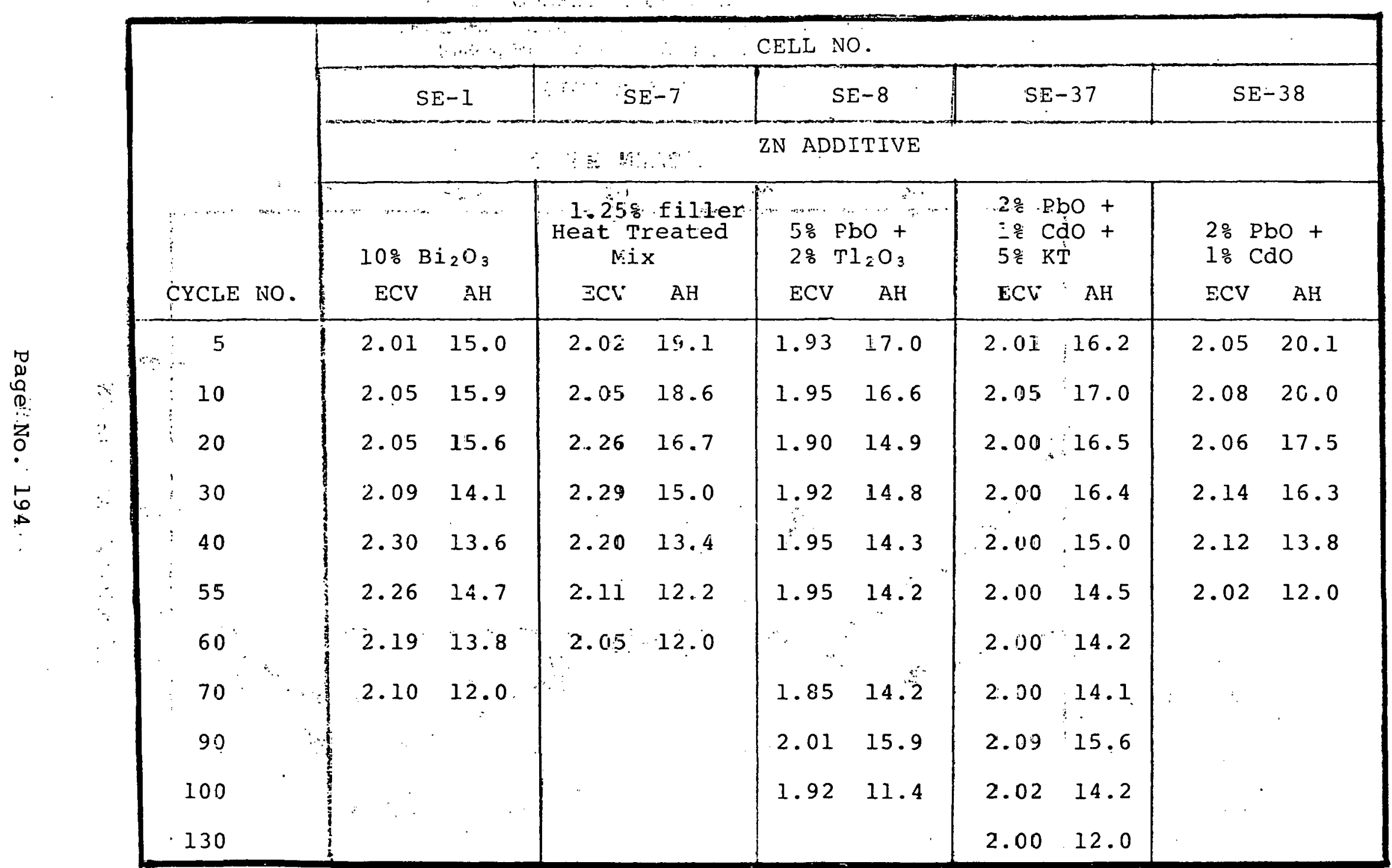

Aho = Capacity: to $1.25 \mathrm{~V}$

$E C V=r$ d-.ff-charge vo!tacis 


\section{ENERGY RESEARCH CORPORATION}

mix to provide the plate with additional strength to resist compression from the positive electrode.

The data indicate that the KT was significant in improving cycle performance. A comparison of SE-38 and SE-37 shows that the KT additive also resulted in lower charge voltage in cells with $\mathrm{Pbo} / \mathrm{CdO}$ additive. The tests conducted in single electrode cells with a PVA separator indicated that bulking additives and the binary zinc additives were superior to the $10 \%$ $\mathrm{Bi}_{2} \mathrm{O}_{3}$ formulation.

Investigations of $z$ inc additives were also conducted in cells with cellulose acetate coated Celgard (K-306). Three layers of the material were used with Pellon polyamide absorber on the positive electrodes and asbestos absorber on the negative plates. (Pellon absorber was used on both plates in cells with PVA separator, in Table V.3.

Cycling results for several zinc electrode variations are given in Table V.4. In addition to the $\mathrm{PbO} / \mathrm{CdO}$ and $\mathrm{PbO} / \mathrm{TI}_{2} \mathrm{O}_{3}$ binary additives, data are also shown for cells with 5\% Cdo additive and a $.004 \mathrm{in}$. layer of Cdo (with TFE binder) on the negative collector. In two of the cells with this construction, the negative plates were heat-treated at $280^{\circ} \mathrm{C}$ for 7 minutes. The plates with $\mathrm{PbO} / \mathrm{Tl}_{2} \mathrm{O}_{3}$ additive in SE-12 were also heat-treated. Also presented are data for cells with HiJell (TM), a bentonite clay from Georgia Kaolin Corporation, which was evaluated as a bulking additive.

The data for Cells SE-68, 69 and 70 indicate that the clay additive is not an appropriate bulking agent. Higher concen; trations of the material improved cycle life "over the cells with 
TABLE V. 4

CYCLE TEST DATA FOR CELLS WITH CELGARD $3-306$

SEPARATC.R AND ZINC ADDITIVE VARIATIONS

\begin{tabular}{|c|c|c|c|c|c|c|c|c|c|c|c|c|c|c|c|c|}
\hline \multirow[b]{2}{*}{ CELL NO. } & \multirow{2}{*}{\multicolumn{2}{|c|}{ ZINC ADDITIVE }} & \multicolumn{14}{|c|}{$\begin{array}{l}\text { SAPACITY TO } 1.25 \mathrm{~V}, \text { Ah } \\
\text { AT CYCLE }\end{array}$} \\
\hline & & & 5 & 10 & 20 & 30 & 40 & 50 & 70 & 80 & 100 & 150 & 175 & 200 & 243 & 265 \\
\hline SE-12 & $5 \% \mathrm{PbO}$ & $+28 \mathrm{Tl}_{\hat{i}} \mathrm{O}_{3}$. Heat Treated & 17.6 & 17.5 & 16.5 & 16.9 & 16.6 & 17.5 & 17.2 & $\vdots 6.2$ & $\geq 5.8$ & 13.6 & 12.0 & & & \\
\hline$S E-40-A$ & $28 \mathrm{PbO}$ & +18 cdo & 19.5 & 19.0 & 18.0 & 17.4 & 17.5 & 18.0 & 17.5 & 57.2 & $\Xi 8.2$ & 16.1 & 15.0 & 14.0 & 12.0 & \\
\hline$S E-40-B$ & $" \quad "$ & " " " & 17.5 & 17.5 & 17.5 & 17.7 & 17.8 & 17.1 & 17.0 & 56.8 & 19.0 & 17.9 & 16.8 & 14.7 & 12.8 & 11.8 \\
\hline $\mathrm{SE}-68$ & $28 \mathrm{PbO}$ & $+18 \mathrm{CdO}+53 \mathrm{Hi} \mathrm{Jell}$ & 19.3 & 19.8 & 15.0 & 10.7 & & & & & & & & & & \\
\hline SE-69 & $28 \mathrm{PbO}$ & $+18 \mathrm{CdO}+108 \mathrm{Hi} \mathrm{Jell}$ & 15.0 & 15.3 & 15.3 & 14.5 & 14.2 & 12.8 & & & & & & & & \\
\hline SE-70 & $28 \mathrm{PbO}$ & $+18 \mathrm{C} d \mathrm{O}+208 \mathrm{Hi} \mathrm{Jell}$ & 15.4 & 15.0 & 15.2 & 15.0 & 14.8 & 13.0 & 12.3 & 12.0 & & & & & & \\
\hline$S E-71-1$ & $58 \mathrm{CdO}$ & + Cdo Layer & 18.2 & 16.2 & 11.8 & & & & & & & & & & & \\
\hline$S E-71-2$ & $" \quad n$ & $" \quad "$ & 19.8 & 19.8 & 17.3 & 12.6 & 11.6 & & & & & & & & & \\
\hline $\mathrm{SE}-72-1$ & $" \quad "$ & " " Heat Treated & 18.3 & 18.3 & 18.5 & 17.8 & 16.5 & 14.8 & 12.2 & 11.6 & & & & & & \\
\hline$S E-72-1$ & $"$ - & n & 17.1 & 17.7 & 18.2 & 17.0 & 15.8 & 14.6 & 12.6 & 11.8 & & & & & & \\
\hline
\end{tabular}




\section{ENERGY RESEARCH CORPORATION}

only 5\% HiJell), but at the expense of lowering cell initial capacity.

A comparison of Cells $\mathrm{SE}-71$ and $\mathrm{SE}-72$ indicates that the heat treatment had a significant effect on cycle life. The two SE-72 cells ran for about 80 cycles, while the SE-71 cells (not heat-treated) ran for 20 and 40 cycles. Cycle life was considerably better for the cell containing heat-treated negative plates with the $\mathrm{PbO} / \mathrm{Tl}_{2} \mathrm{O}_{3}$ binary additive. This cell, $\mathrm{SE}-12$, ran for 175 cycles before delivering less than 12 Ah (60\% of nominal capacity)

The best cycle performance achieved in single plate cells was in the SE-40 cells with $\mathrm{PbO} / \mathrm{CdO}$ binary additive. The two cells ran for 243 and 265 cycles. Voltage and capacity data for Cells SE-12 and SE-40 are shown in Figures V. 4 and V. 5 .

Single electrode test cells usually exhibit a rise in the end-of-charge voltage (ECV) early in the cycle test. The ECV reaches a maximum and then begins to decrease. This decrease is usually accompanied by a decline in discharge capacity. Figures V. 4 and V. 5 both show this pattern but in the SE-40 cells, the rise in ECV was delayed until late in the cycle test. The SE-40 cell also achieved higher utilization than SE-12, delivering more than 20 Ah at one point.

Zinc electrode testing in cells containing $\mathrm{K}-306$ separators has produced the highest cycle life achieved to date in the single electrode test. As found in the cells with a PVA separator, the tests have demonstrated the superiority of the binary additives. 2.2.2 Evaluation of Separator System Design

The single electrode test has been used to evaluate various Page No. 197 
Discharge

Capacity to

1. $25 \mathrm{~V}$, Ah

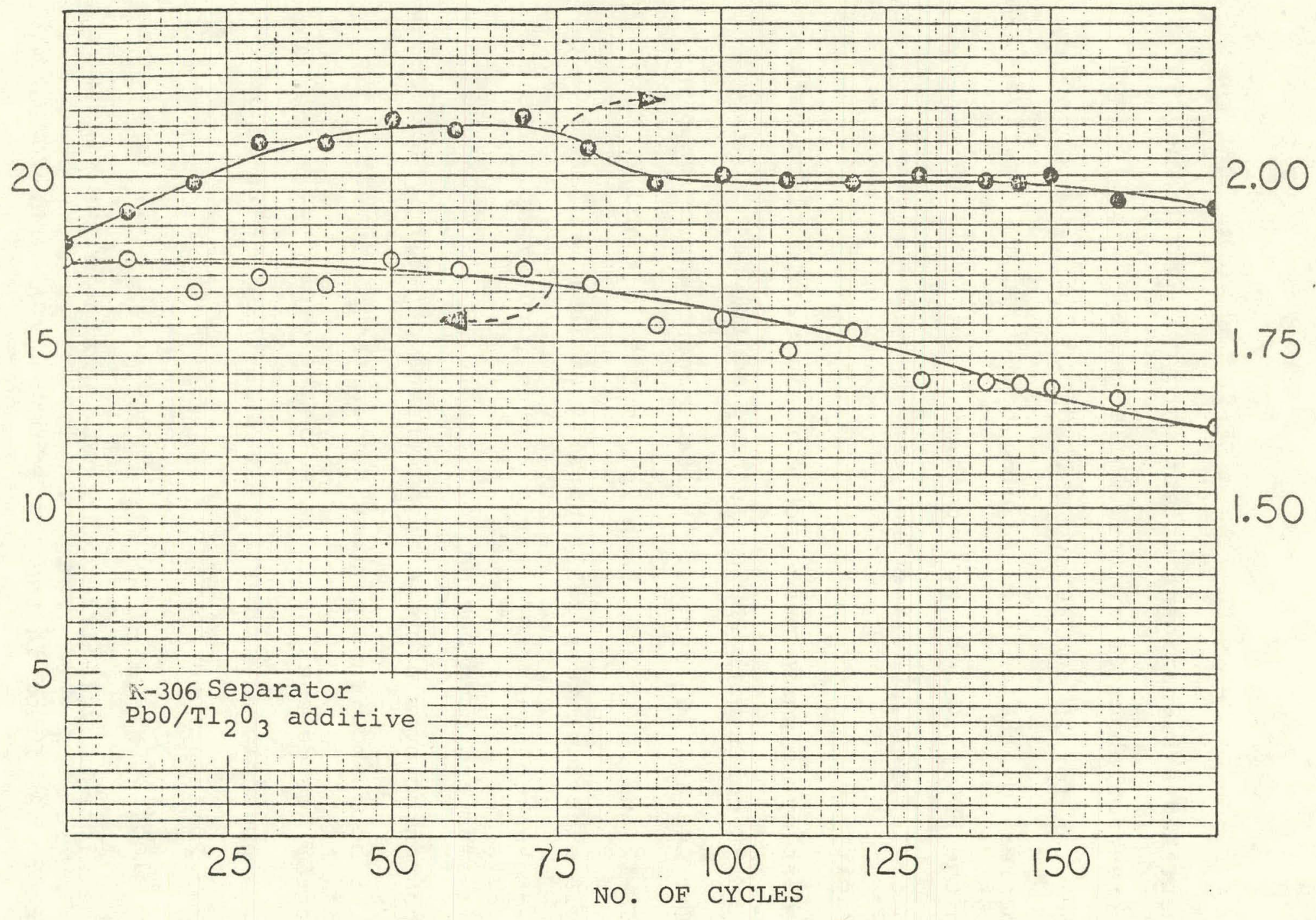

End of

Charge

Voltage

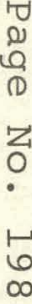

FIGURE V.4

CYCLE DATA FOR CELL SE-12 


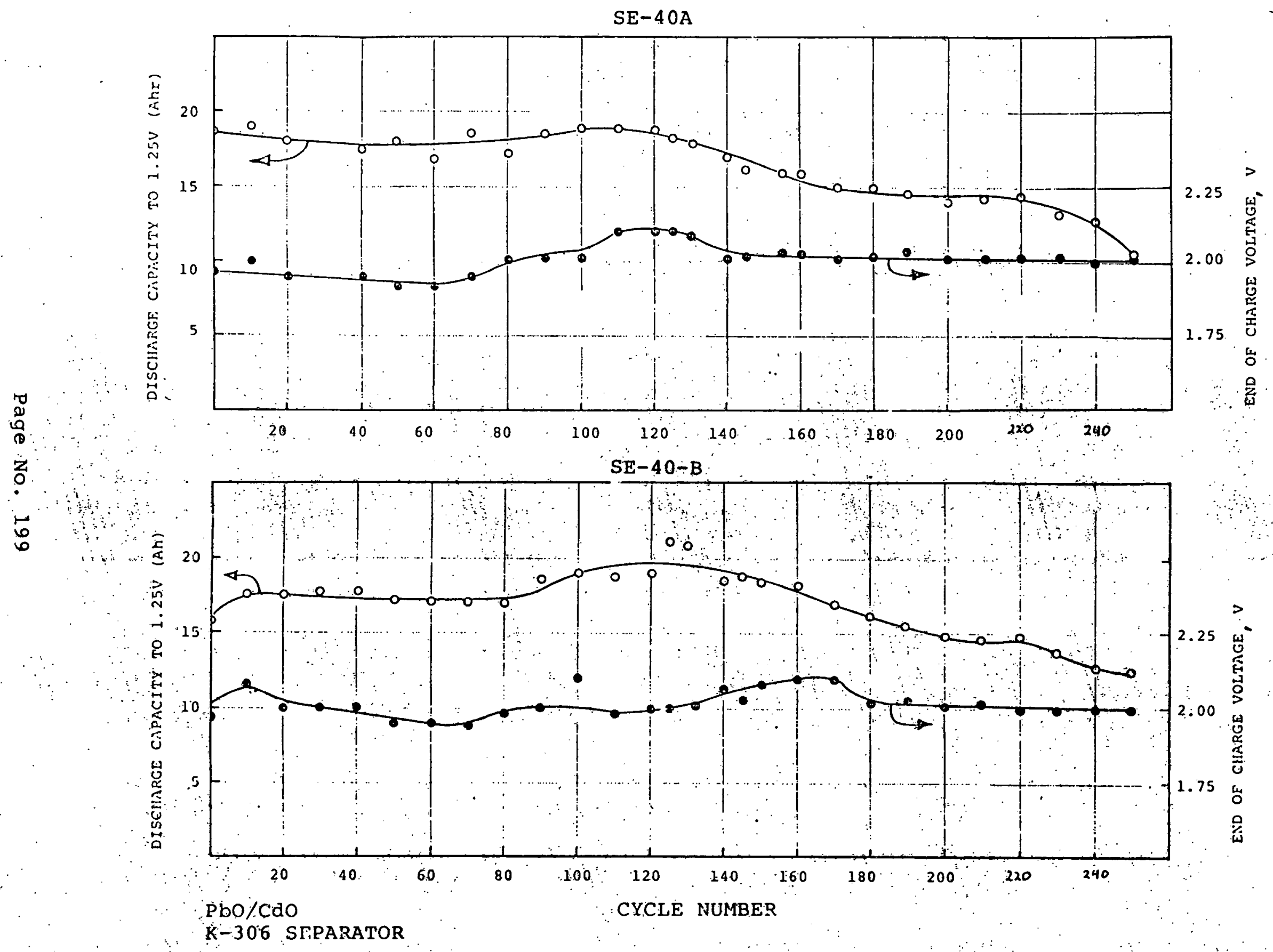

FIGURE V.5 CYCLE DATA FOR CELLS WITH PBO/CAO ADDITIVE 


\section{ENERGY RESEARCH CORPORATION}

separator systems with the goal of finding a separator design with good zinc penetration resistance and stability in concentratec $\mathrm{KOH}$. The single electrode test also provides a good measure of the system's resistance to dryout under the gassing and high pressure conditions of large cell geometry.

The best performing separator system in the single plate tests is the cellulose acetate coated Celgard K-306. (3 layers) combined with asbestos negative absorber wrap and Pellon polyamide positive electrode wrap. Cells with this separator and Pbo/Cdo. zinc additive have run for over 240 cycles before delivering less than $60 \%$ of nominal capacity. A comparison of this separator system and the PVA separator cạn be made with cells discussed in. the previous section. Cell SE-8, with the PVA separator, ran for 98. cycles while CelI SE-12, with K-306 separator, ran for 175 cycles. Subsequent cell tests have continued to demonstrate the superiority of the k-306 film. The section on large cell tests will present aata which demonstrate the importance of the ashestos absorber wrap:

Cells with several other separator systems are detailed in Table V. 5. The best separator in this series is the combination inorganic film and cellophane in Cell SE-17. The inorganic film is a $5 \mathrm{mil}$ Teflon bonded, rolled shept. In addition to being a very good electrolyte reservoir, the material may also limit dendrite growth by reacting with zincate to form insolumle zincates.

Additional evaluation of promising design variables such as the K-306 film, inorganic film and Pbo/Cdo zinc electrode additive has continued in 250 Ah cells. A discussion of these 
CYCLE DATA FOR CELLS WITH $\mathrm{Bi}_{2} \mathrm{O}_{3}$

ZINC ADDITIVE AND VARIOUS SEPARATOR SYSTEMS

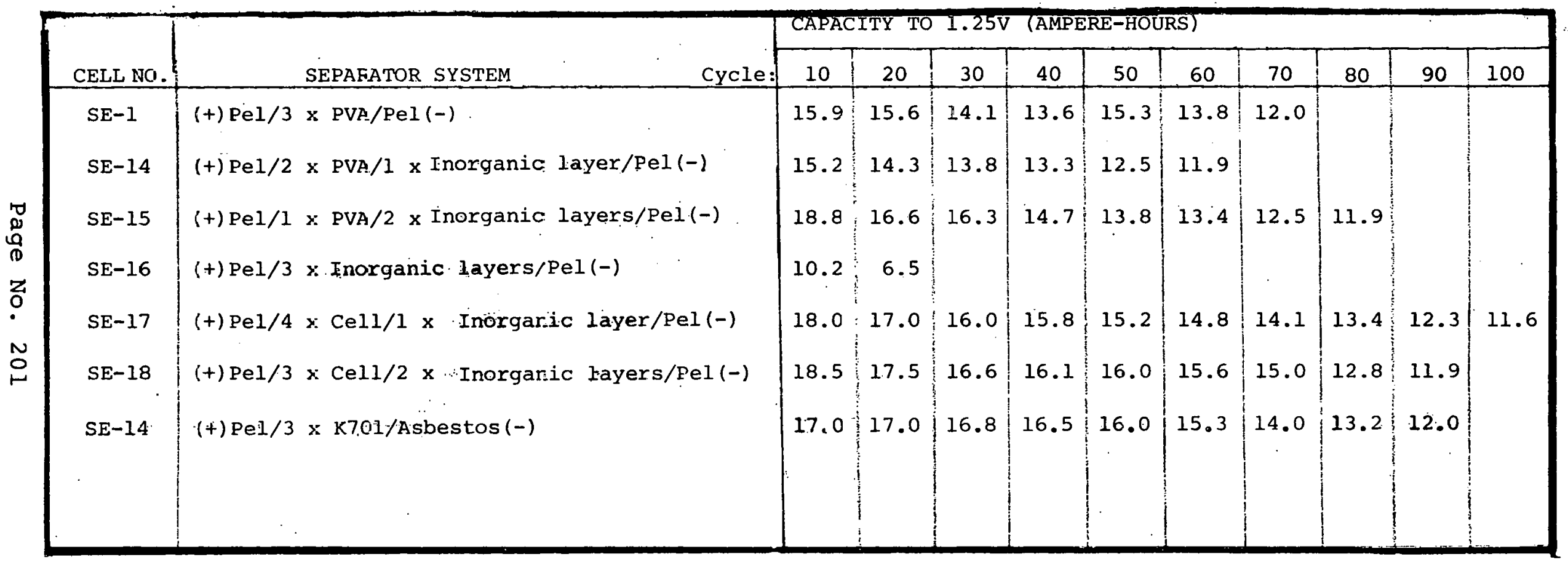

Pel: Pellon ${ }^{\mathrm{TM}}$ Absorber

$\mathrm{Ca}(\mathrm{OH})_{2}: 5 \mathrm{mil} \mathrm{Ca}(\mathrm{OH})_{2}:$ film

Cell: Cellophane

Grc Abs: Grace Absorber \#114

Grc Sep: Grace 4 mil separator

K701: Celgard/Cellophane Laminate 


\section{ENERGY RESEARCH CORPORATION}

tests is presented in the next section.

2.3250 AH CELL TESTS

Full-size, EV type, 250 Ah cells are used to evaluate var-

iations in component design, charge procedures, and cell geometry. Most cells are tested on a constant current cycle, although twostep charge, constant potential charge and pulsed discharge have been under investigation.

2.3.1 Cell Test with PVA Separator and $\mathrm{Bi}_{2} \mathrm{O}_{3}$ Zinc Electrode Additive

Farly in the year large cell testing was conducted on cells containing a $\bar{P} \overline{V A}$ separator (3 Layer); Pellon polyamide absoriver on both electrodes, and $108 \mathrm{Bi}_{2} \mathrm{O}_{3}$ in the zinc electrode. The standard cell design consists of 14 positive and 15 negative plates. This design has been found to reproducibly deliver about 55 cycles (at $77 \%$ DOD and without reconditioning during the cycle test) before cell capacity falls to $60 \%$ of nominal. Dissection analysie of failed cells has indicated that separator degradation and zinc shorting throughout the inner portion of the plates contributed to cell failure. Drying out of the center portions of the negative plates has consistently been seen in cells with this design.

'l'wo approaches were tried to reduce gas entrainment in the cell pack, which accelerates dryout and separator degradation. A cell was built with the standard design, but only 13 plate pairs, to reduce pack cumpression. A second design included grooved positive and negative electrodes to improve gas and liquid transport in the cell pack. 
The cells were put through a cycle test consisting of a 37.2 amp charge for 5.75 hours $(214 \mathrm{Ah})$ followed by a 2.25 hour discharge at 85 amps. (191.25 Ah). This represents a $12 \%$ overcharge, $77 \%$ DOD test in $250 \mathrm{Ah}$ cells. The test results of the three designs are shown in Figure V.6.

Neither design modification produced better results than the standard. The cycle performance of the cell with grooved plates was stable for 35 cycles; however, the end of discharge voltage was low as indicated by a plateau in the discharge curve. This second plateau was due to the use of contaminated nickelhydroxide and has been eliminated by washing the active material prior to electrode fabrication.

Because the negative electrode and separator design have been identified as the components most in need of development, the majority of testing in the past year has utilized a standardized positive electrode. Active material from a commercial source containing $95 \% \mathrm{Ni}(\mathrm{OH})_{2} \cdot 1 / 4 \mathrm{H}_{2} \mathrm{O}$ and $1.58 \mathrm{CO}(\mathrm{OH})_{2}$ was usually used. ERC active material (also with $1.5 \% \mathrm{Co}(\mathrm{OH}) \cdot 1 / 4$ $\mathrm{H}_{2} \mathrm{O}$ ) was evaluated in cells with. PVA separator along with $\mathrm{Bi}_{2} \mathrm{O}_{3}$ as the negative aditive. The test results, given in Table V.6, indicate that the commercial and ERC materials perform equivalently i.n cells with PVA and $\mathrm{Bi}_{2} \mathrm{O}_{3}$.

The early baseline design was also used to evaluate two alternate charge procedures. One cell was put on cycle test with a two-step charge consisting of $5-1 / 2$ hours of charge at 34.4 amps followed by $4-12$ hours of charge at 6 amps. Another 


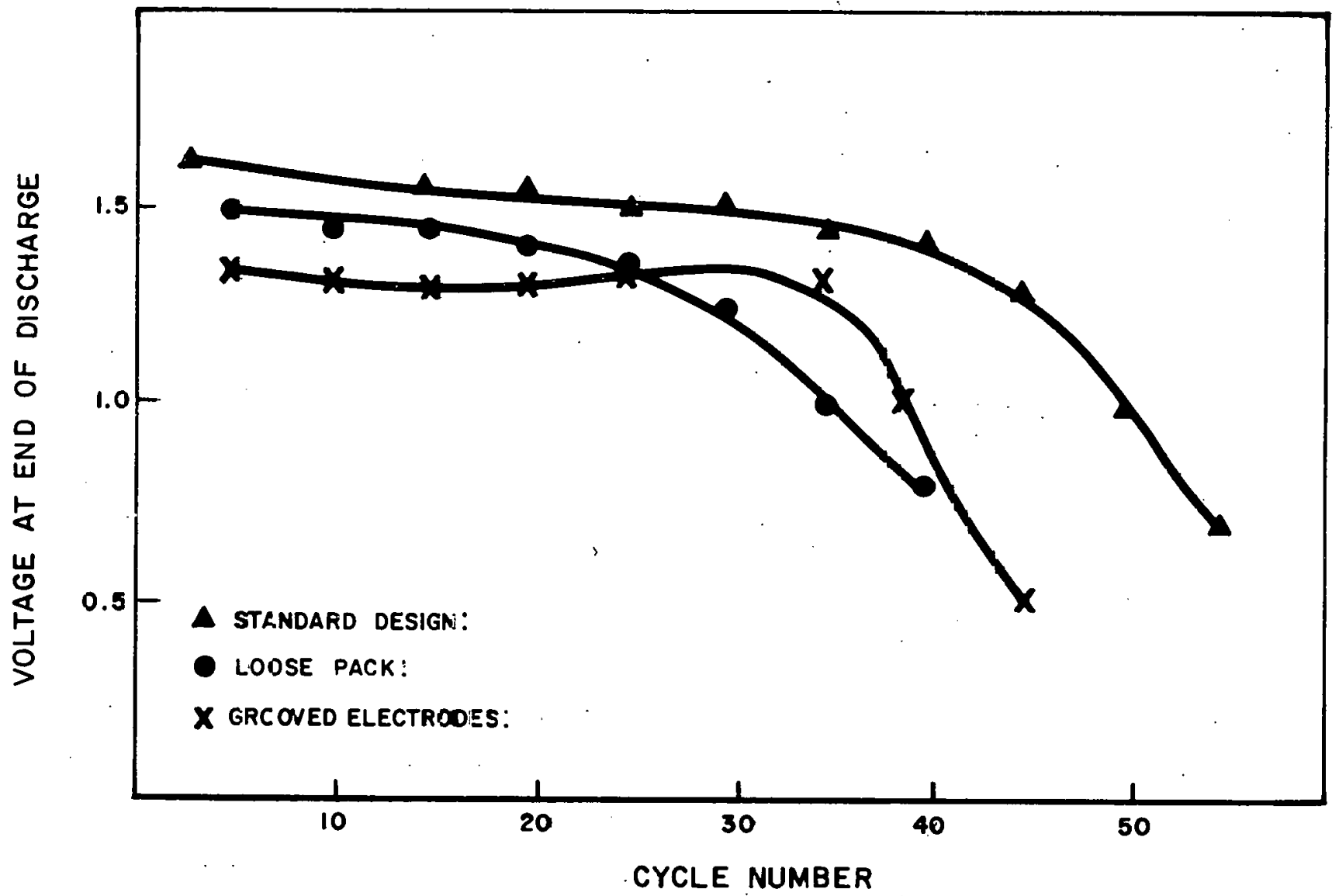

FIGURE V. 6

CYCEE TEST RESULTS OF CELLS ÑITH

PVA SEPARATOR AND $\mathrm{Bi}_{2} \mathrm{O}_{3}$

ZINC ADDITIVE 
TABLE V. 6

CYCLE PERFORMANCE Ó CELLS WITH ERC

AND COMMERCTAL, $\mathrm{Ni}(\mathrm{OH})_{2} / \mathrm{CO}(\mathrm{OH})_{2}$ POSITIVE ACTIVE MATERIAL

\begin{tabular}{|c|c|c|c|c|}
\hline \multicolumn{5}{|c|}{ GROUP 137-II COMMERCIAL Ni, ASBURY GRAPHITE } \\
\hline \multirow{2}{*}{$\begin{array}{c}\text { CYCLE } \\
\#\end{array}$} & \multicolumn{2}{|c|}{ CELL 137-II-1 } & \multicolumn{2}{|c|}{ CELL 137-II-2 } \\
\hline & ECV & EDV & $\mathrm{ECV}$ & EDV \\
\hline 4 & 1.923 & 1.53 & 1.92 & 1.54 \\
\hline 15 & 1.94 & 1.49 & 1.93 & 1.49 \\
\hline 20 & 1.98 & 1.52 & 1.91 & 1.49 \\
\hline 24 & 1.98 & 1.50 & 1.90 & 1.46 \\
\hline 30 & 2.05 & 1.39 & 1.99 & 1.40 \\
\hline 35 & 2.10 & 1.10 & 2.01 & 1.10 \\
\hline 50 & 2.15 & 1.00 & 2.11 & 1.15 \\
\hline
\end{tabular}

\begin{tabular}{|c|c|c|c|c|}
\hline \multicolumn{2}{|c|}{ GROUP 137 ERC Ni, ASBURY GRAPHITE } \\
\hline CYCLE & \multicolumn{2}{|c|}{ CELL $137-1$} & \multicolumn{2}{|c|}{ CELL $137-2$} \\
\cline { 2 - 5 }$\#$ & ECV & EDV & ECV & EDV \\
\hline 5 & 1.88 & 1.54 & 1.88 & 1.55 \\
15 & 2.02 & 1.53 & 2.03 & 1.54 \\
20 & 2.03 & 1.52 & 1.99 & 1.48 \\
25 & 2.06 & 1.50 & 2.04 & 1.45 \\
30 & 2.12 & 1.31 & 2.04 & 1.25 \\
35 & 2.12 & 1.26 & 2.00 & 1.20 \\
49 & 1.98 & 0.85 & 1.86 & 0.30 \\
\hline
\end{tabular}

$E C V=$ Voltage at end of 214 Ah charge

$\mathrm{EDV}=$ Voltage at end of 191.25 Ah discharge

Zinc additive in all cells: $\mathrm{Bi}_{2} \mathrm{O}_{3}$

Separator in all cells: PVA 


\section{ENERGY RESEARCH CORPORATION}

cell was put on cycle test with a modified constant potential charge that limited charge current as the cell voltage. All discharges were at 35 amps. The tiwo-step cycle represents $12 \%$ overcharge, as does the standard constant current test. On the modified constant potential test; charge input on a fresh cell was $214.2 \mathrm{Ah}$, representing about a $12 \%$ overcharge.

Results fur Lliree cells evaluatcd on different regimes are shown in Figure.V. 7.: The data indicate that of the three charging methods tested, the constant current charge was superior. 2.3.2 Cell Tests with Advanced Separator and Flectrode Designs

Design developments during the past year have significantly improved cell performance over the earlier $\mathrm{PVA} / \mathrm{Bi}_{2} \mathrm{O}_{3}$ design. As described above, full-size single electrode cells with improved components have delivered in excess of 240 cycles at 100 e DOD. The general direction of recent developments has been away from membrane separators, such as PVA, and toward more stable microporous films, such as Celgard materials. Zinc electrode development has focused on binary additives such as $\mathrm{CdO} / \mathrm{PbO}$ and $\mathrm{PbO} / \mathrm{Tl}_{2} \mathrm{O}_{3}$.

Test results and dissection analyses in $\mathrm{PVA} / \mathrm{Bi}_{2} \mathrm{O}_{3}$ cells have demonstrated a need for an improved absorbcr wrap on the negative electrode. Several experimental materials have been studied, but the only material found to be significantly better than Pellon was $10 \mathrm{mil}$ thick fuel cell grade asbestos. Cycle data for cells with asbestos and Pelion negative absorber wraps are shown in Figure V.8. The figure includes voltage at the end of each 191.25 Ah discharge as a function of cycle number. 


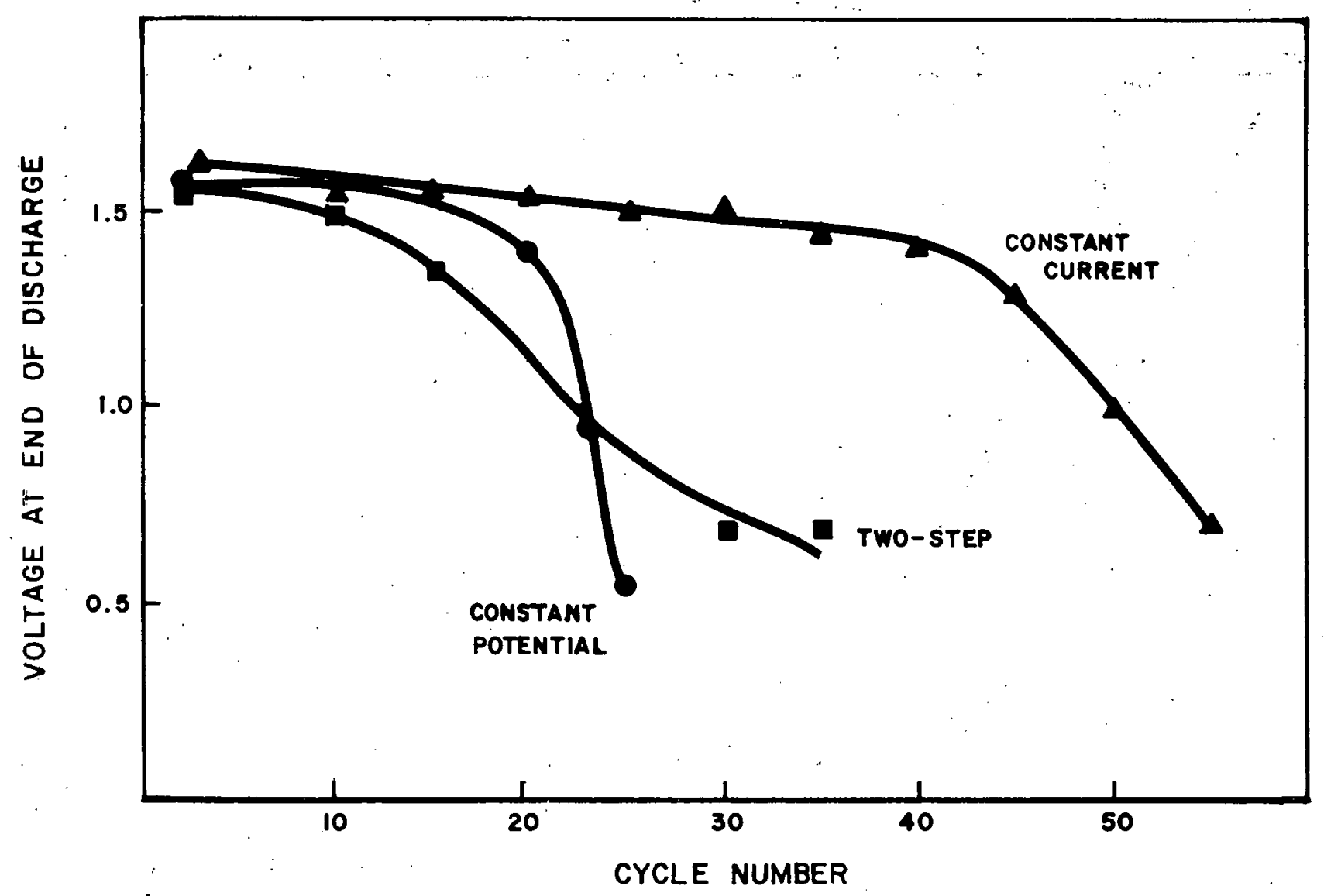

FIGURE $\quad$. 7

Ni-Zn CYCLE TEST WITH VARIOUS CHARGE PROCEDURES PVA SEPARATOR AND $\mathrm{Bi}_{2} \mathrm{O}_{3}$ ADDITIVE 


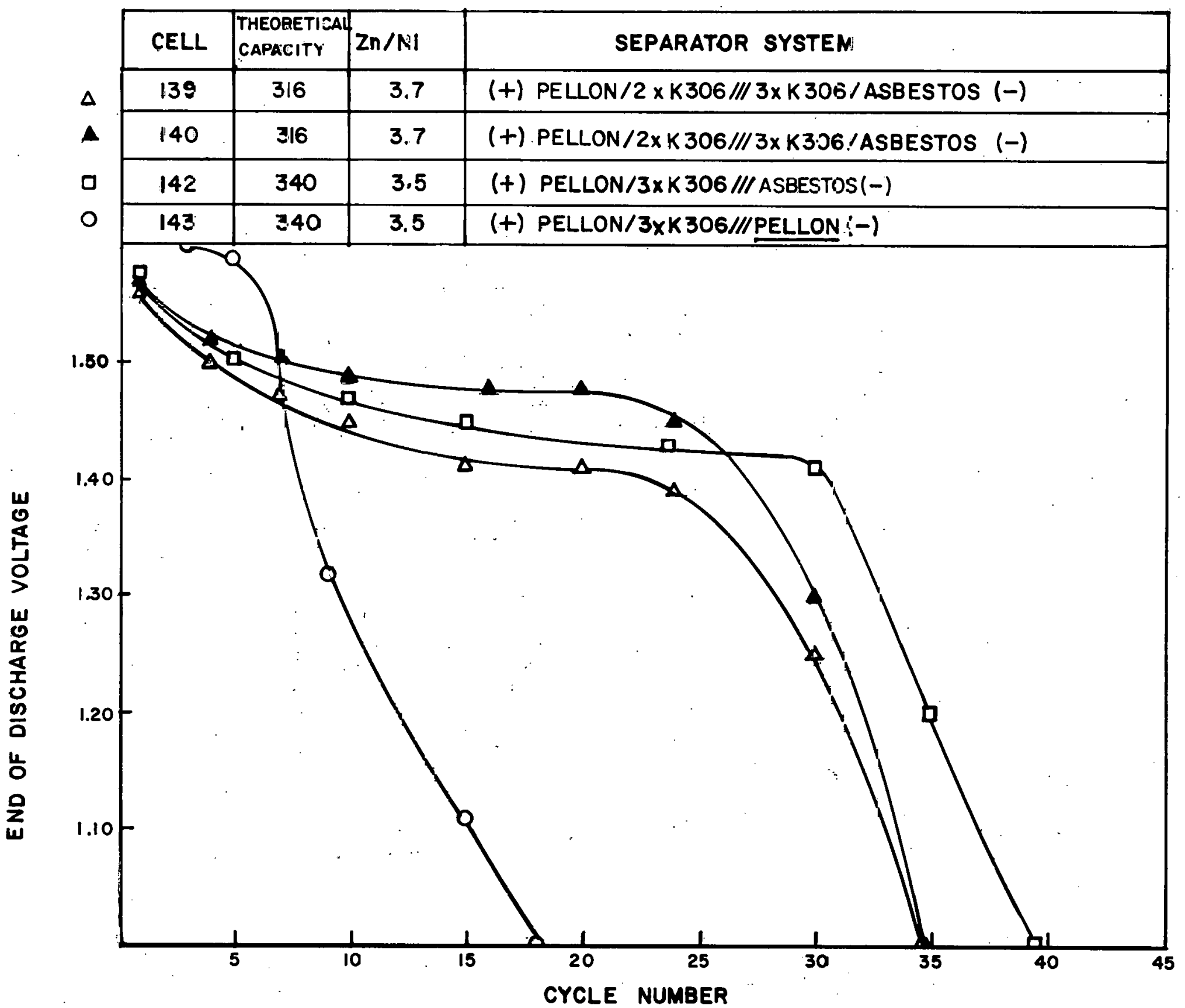

CYCLE PERFORMANCE CF ZELLS WITH PELLON AND ASBESTOS ABSORBER 


\section{ENERGY RESEARCH CORPORATION}

The negative electrode designs in all cells in Figure V. 8 were the same, with $5 \%$ potassium-titanate bulking additive. Results indicate that in these cells, the asbestos wrap was necessary to prevent early failure from dryout of the separator and zinc electrodes. The data also show that the separator design with three layers of coated Celgard had comparable performance to cells with five layers of the film. This may be due to the reduced DOD on the cells with fewer layers (DOD is 7\% less for the cells with fewer layers because space is available for an extra pair of plates. However, it does indicate that the threelayer design is acceptable within the limits of this test.

The effect of the asbestos absorber in cells.with the $\mathrm{PbO} / \mathrm{CdO}$ zinc additive is shown in Figure V.9, which presents cycle data for cells with Pellon and asbestos absorbers. Cell 159 is a scale-up of the single electrode cells which exceeded 240 cycles. Cell 163 is a similar design in which the asbestos wrap was replaced by Pellon, allowing room for more active material. Test results show that despite its higher capacity and zinc ratio, the cell with Pellon absorber failed earlier than the cell with asbestos.

Another design which had shown promise in full-size, single electrode tests was the combination of membrane films with ERC's $5 \mathrm{mil}$ inorganic film. A combination of cellophane and the inorganic film had given good performance in these tests. A series of similar designs were tested in 250 Ah cells and the longest life was achieved in Cell 118, with 2 layers of PVA combined with the inorganic film. The cell also had negative plates made with a heat-treated zno/inorganic filler mix, 


\begin{tabular}{|c|c|c|}
\hline CELL & SEPARATOR DESIGN & CYCLE LIFE * \\
\hline 159 & (+) PELLON / 3 K K306 III ASBESTOS (-) & 130 \\
\hline 163 & (+) PELLON / 3xK306 /II PELLON (-) & 90 \\
\hline
\end{tabular}

* CYCLE LIFE = HUMBER OF CYCLES WITH CAPACITY MORE THAN $60 \%$ OF NOMINAL

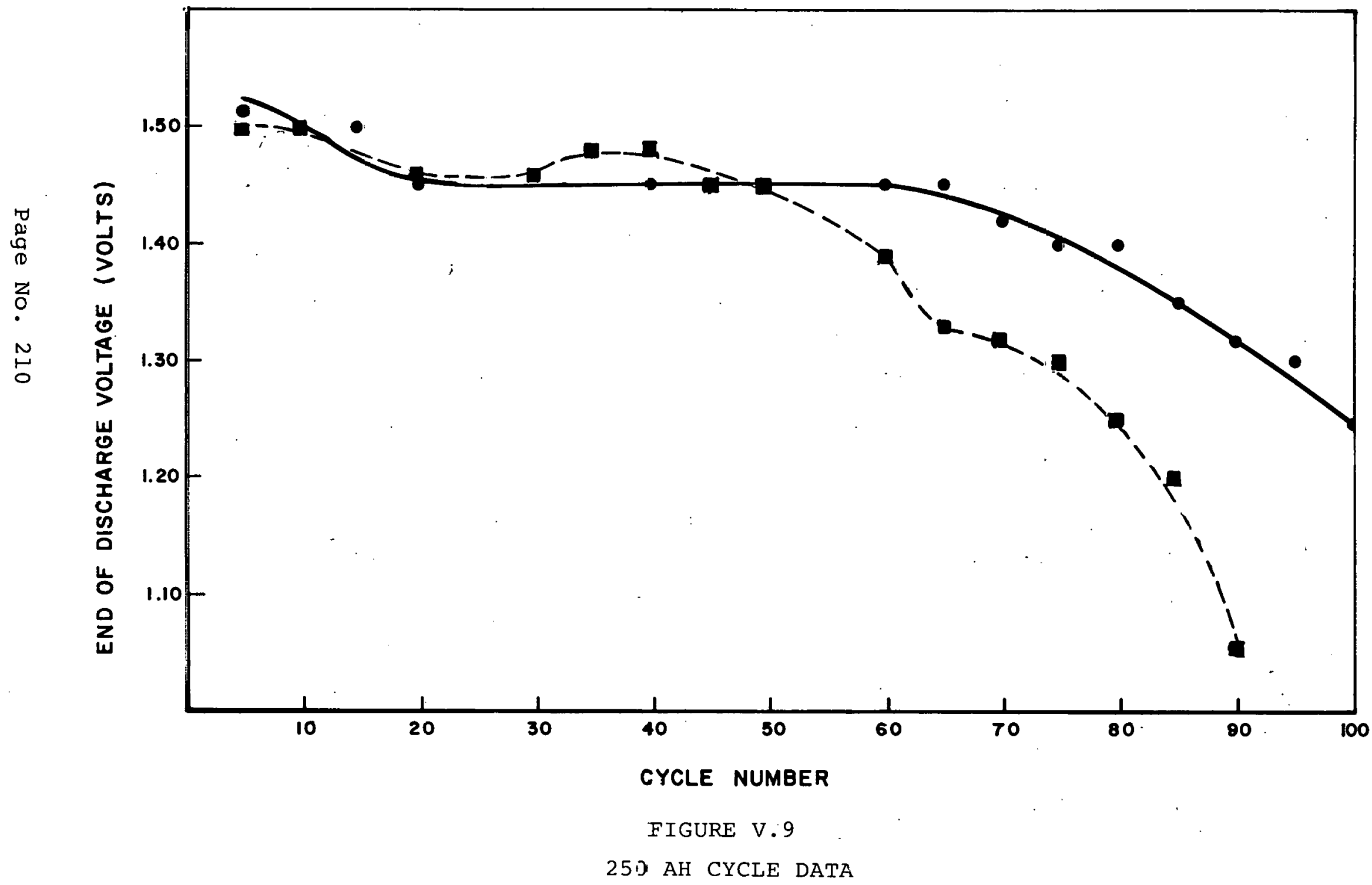


which had performed well in $20 \mathrm{Ah}$ cell tests. Cycling of cell 118, along with an early baseline design cell and more advanced designs, are show in Figure.V.10. While cell 118 ran for more cycles than the early baseline cell, the newer designs had even longer cycle life.

Cell 151 contained positive electrodes 19\% less dense than standard, and negative plates $17 \%$ less dense than standard. This design was built to determine if the electrodes' lower densities would reduce cell pack compression and improve performance.

Cell 157 was built with another approach for reducing pack compression. The cell contained a standard density electrode but was built in a long, thin geometry. The cell is only four plate pairs thick with plates that measure 6 in. high $\times 31-1 / 4$ in. Iong. This design was fabricated to determine if a reduction in the compression, wetting and thermal problems in the cell pack was possible.

As indicated in Figure V.10, the low density and long geometry cells performed about the same. A comparison with Figure V.y shows that these cells performed better than Cell 159, with standard density plates and Pellon absorber, but not as good as Cell 163, with asbestos negative plate absorber.

The effect of the longer cell geometry on cell temperature can be seen in Figures V.II and V.12, which present voltage and temperature data for cells 157 and 151 on cycle test. The figures show that the long cell ran up to $13^{\circ} \mathrm{C}$ cooler during discharge than the standard geometry design.

\subsubsection{Simulated Vehicle Use Test}

A test regime has been established for 250 Ah cells 


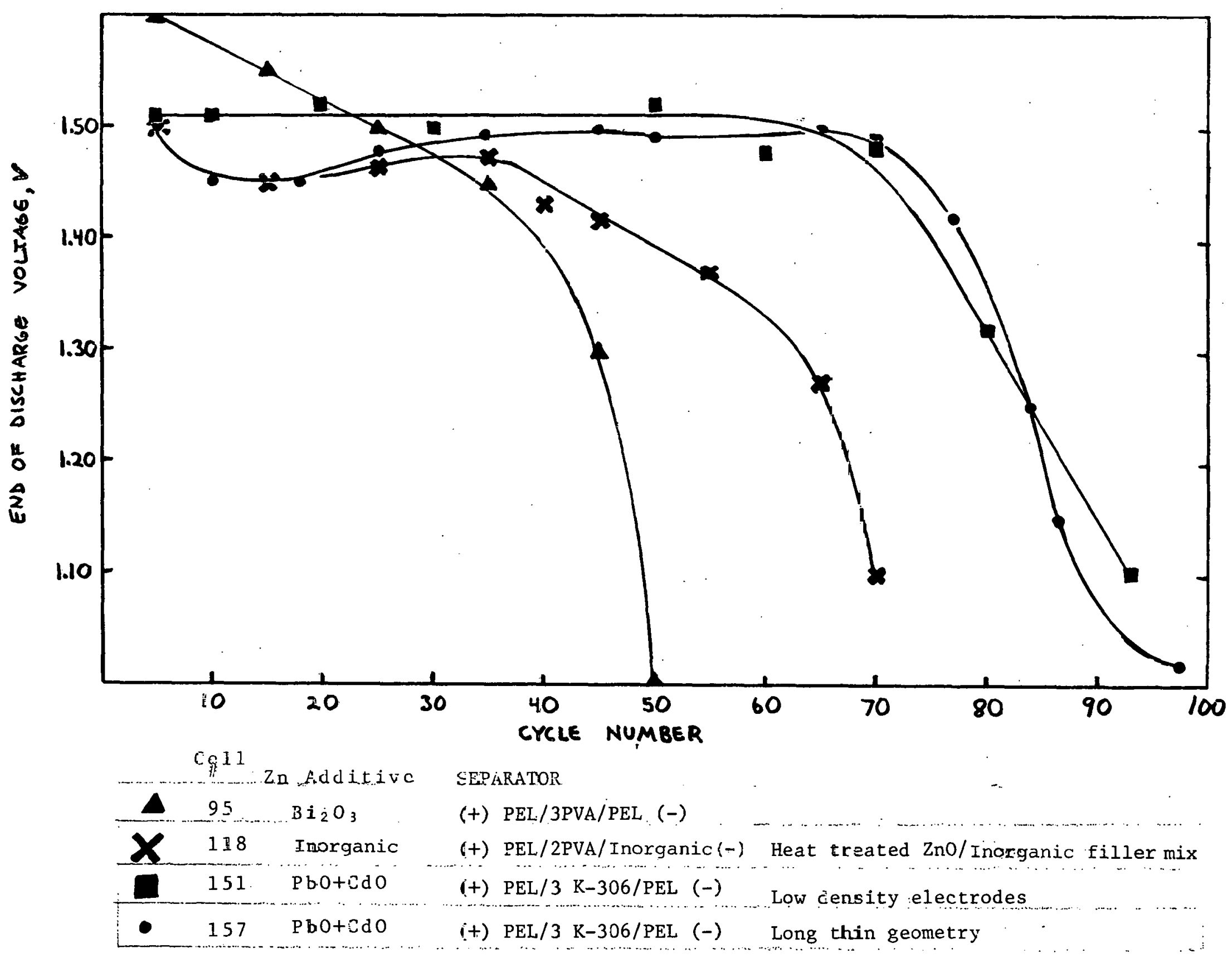

FIGURE V.10

250 AH ELL CYZLE TEST DATA 


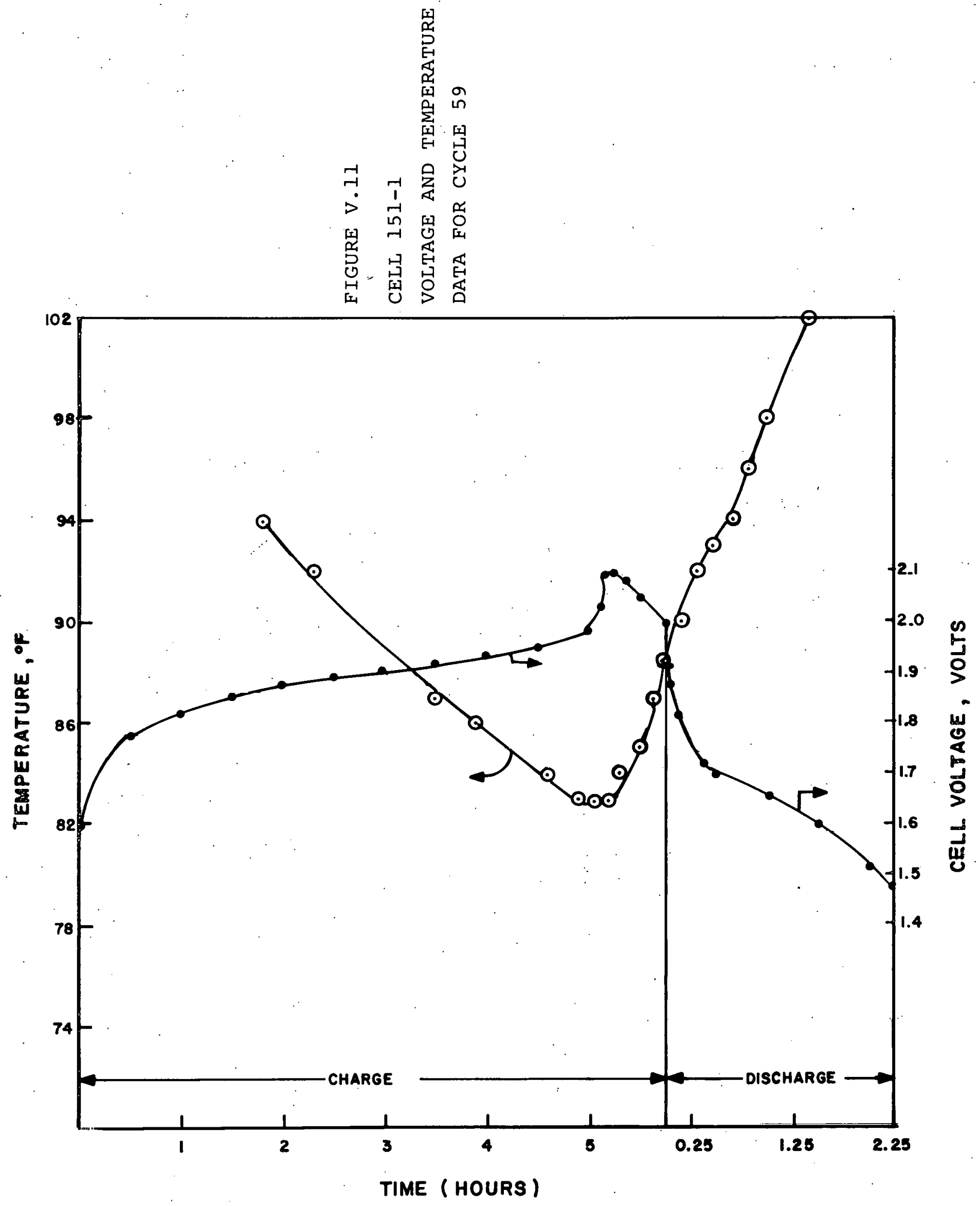

Page No. 213 

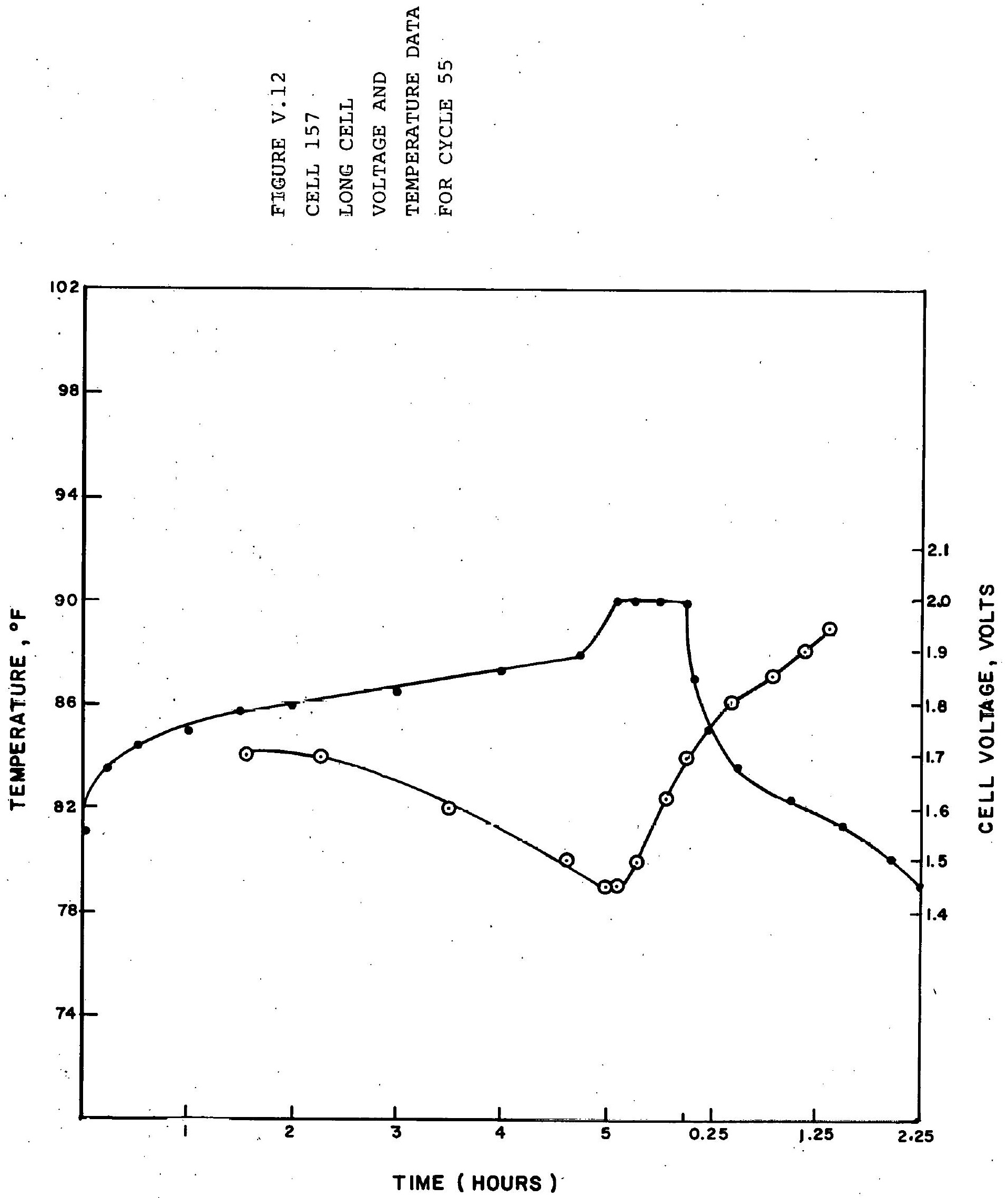

Page No. 214 
which will simulate a certain pattern of electric vehicle use. The test regime is based on trip distribution for trips of 100 miles and under. Based on information from the Federal Highway Administration, a trip distribution model was generated which approximates the maximum electric vehicle use for 758 of all operators. This distribution is given in Table V.7. The mileage shown for 25-mile trips is actually a total of all trips 25 miles or less.

For the discharge portions of the test, it was decided to use the J227AD GE-Chrysler vehicle current profile derived at ANL. Each time this profile, shown in Figure V.13, is run, $2.187 \mathrm{Ah}$ is removed from the battery and $0.95 \mathrm{miles}$ of driving is simulated. After each discharge, the cells are recharged at 38 amps to a charge input of $10 \%$ more capacity than was removed.

The weekly test sequence is shown in Figure V.14. Each week the test simulates 1645 miles and every six weeks, one year's operation (9870 miles according to the model).

Testing was started on a $250 \mathrm{Al}$ cell with the cao/Pbo additive and $\mathrm{K}-306$ separator. The cell design included an excessively tight pack to accommodate a higher zinc ratio. This has been found detrimental to performance and duplicates of this cell (Design 162) have only delivered about 30 cycles on the $77 \%$ DOD test. On the vehicle simulation test, the cell ran the equivalent of 12,700 miles before its range fell to 60 miles.

Test results for the cell during 25 and 100 mile discharges are shown in Figure, V.15. After being tested for the equivalent of 4500 miles, the cell began to deliver less than 
ENERGY RESEARCH CORPORATION

TABLE VI

ANNUAL ELECTRIC VEHICLE TRIP

DISTRIBUTION FOR 75TH PERCENTILE OPERATOR

\begin{tabular}{ccc}
$\begin{array}{c}\text { Trip } \\
\text { Mileage }\end{array}$ & $\begin{array}{c}\text { Number of } \\
\text { Trips }\end{array}$ & $\begin{array}{c}\text { Annual } \\
\text { Mileage }\end{array}$ \\
\hline 25 & 228 & 5700 \\
35 & 42 & 1470 \\
50 & 24 & 1200 \\
75 & 12 & 900 \\
100 & 6 & 600 \\
TOTAL & & 9870 \\
\hline
\end{tabular}

Page No. 216 


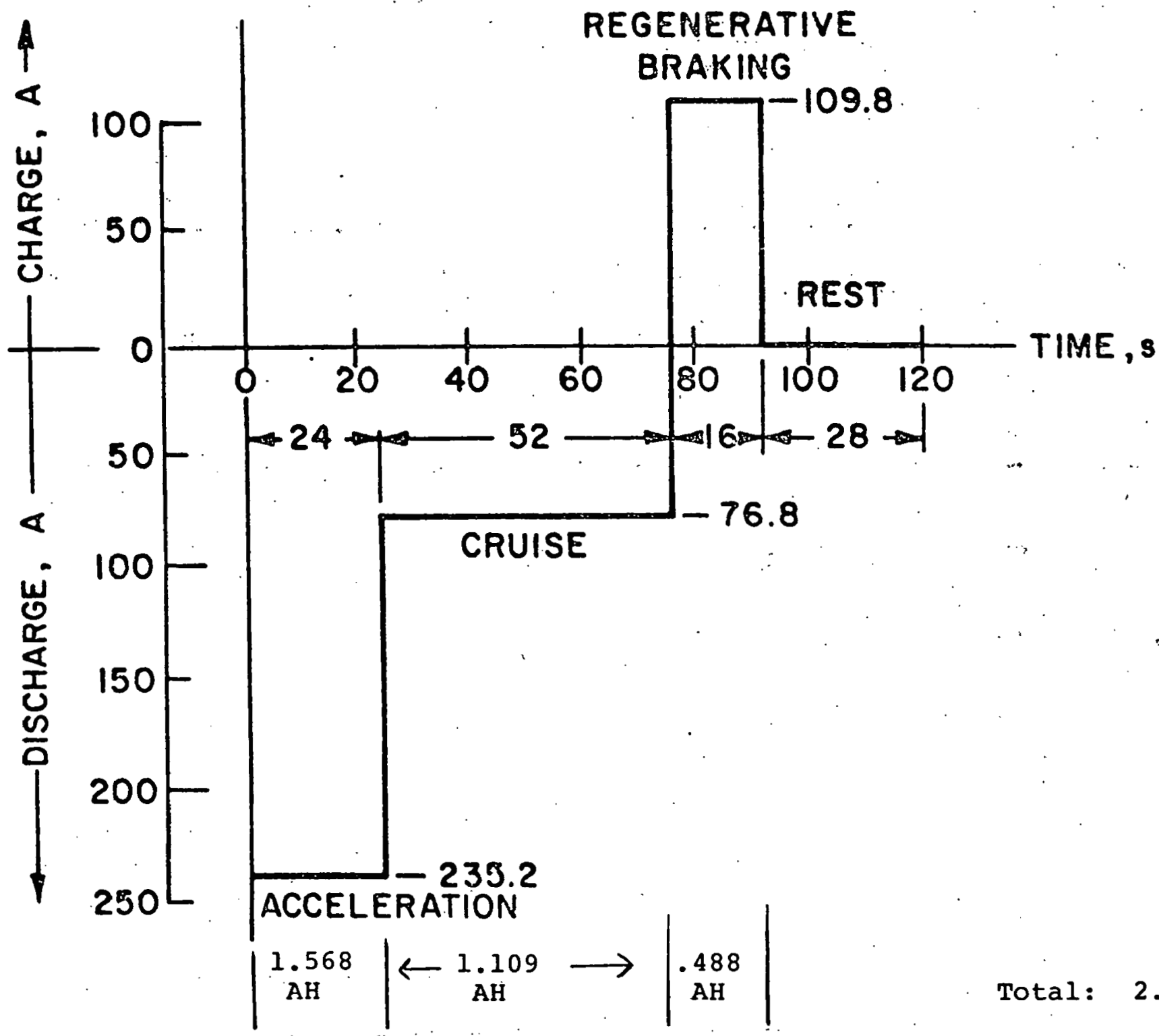

REGENERATIVE

BRAKING

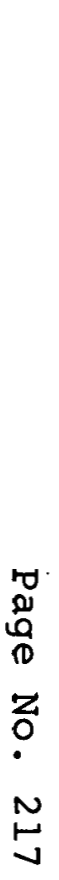

FOUR CURRENT STEPS TO PROVIDE A SIMPLIFIED APPROXIMATION TO THE J227AD/DOE-GE-CHRYSLER VEHICLE (WITH REGENERATIVE BRAKING) 


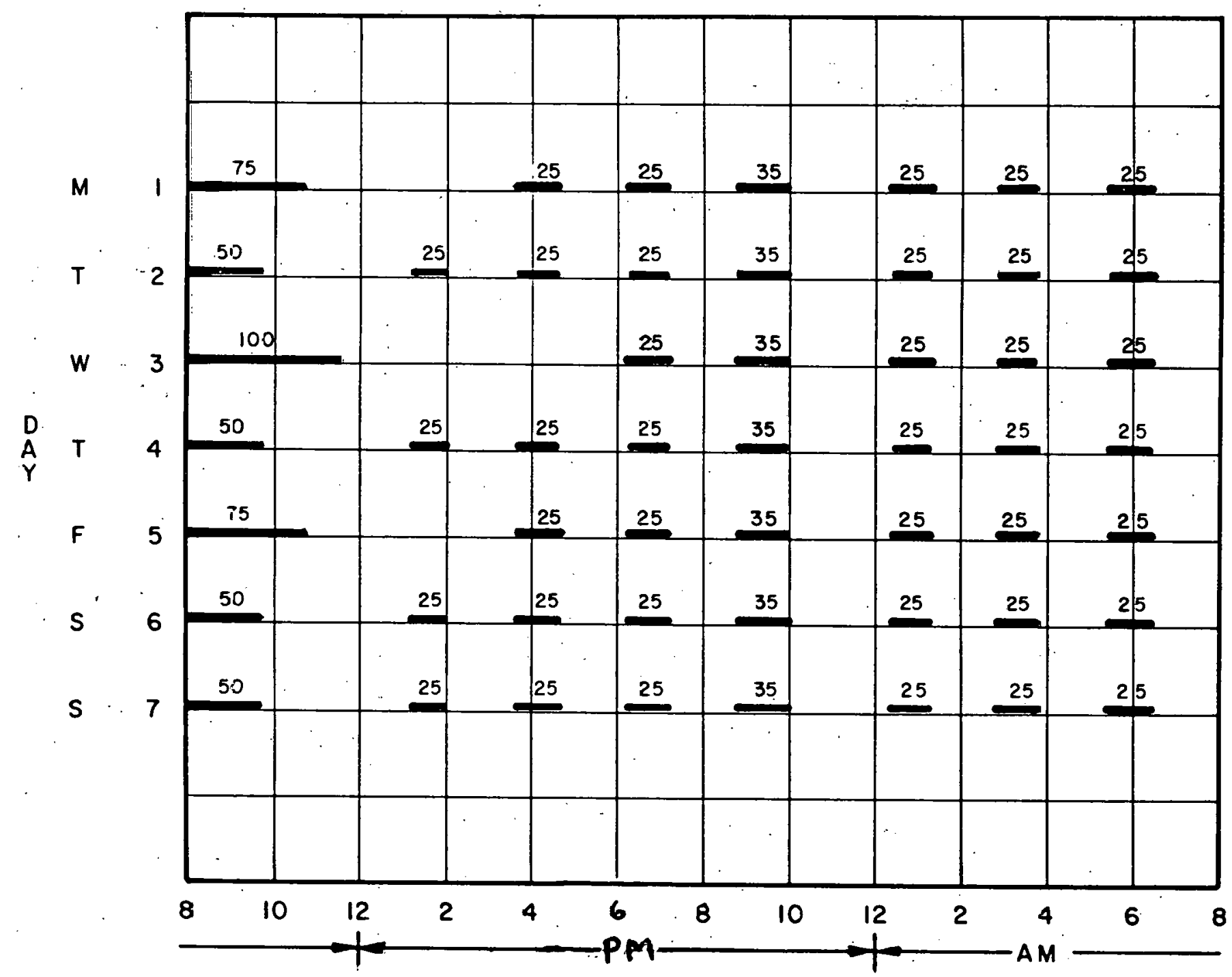

FIGURE V. 14

TIME

DEPTH

TEST SEQUENCE 

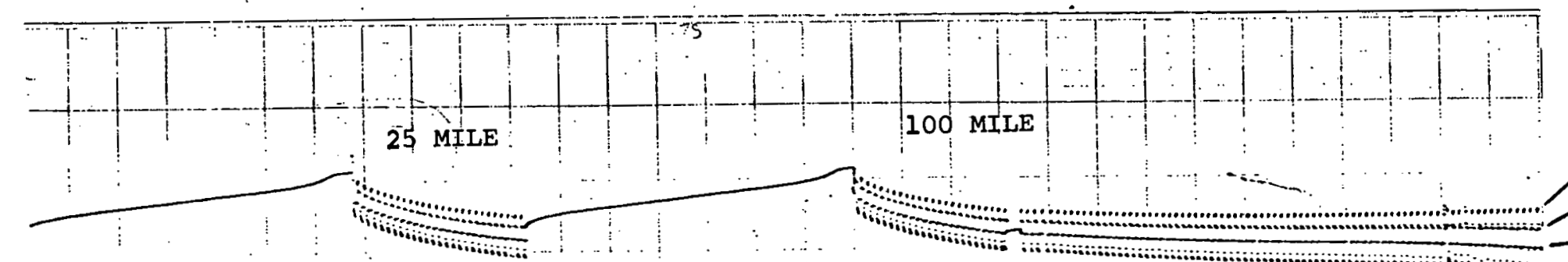

110 Amps Charge OCV

77 Amp Dischargel -233 Amp Discharge

-1
0
0
0
$z$
0
0
$N$
0
0
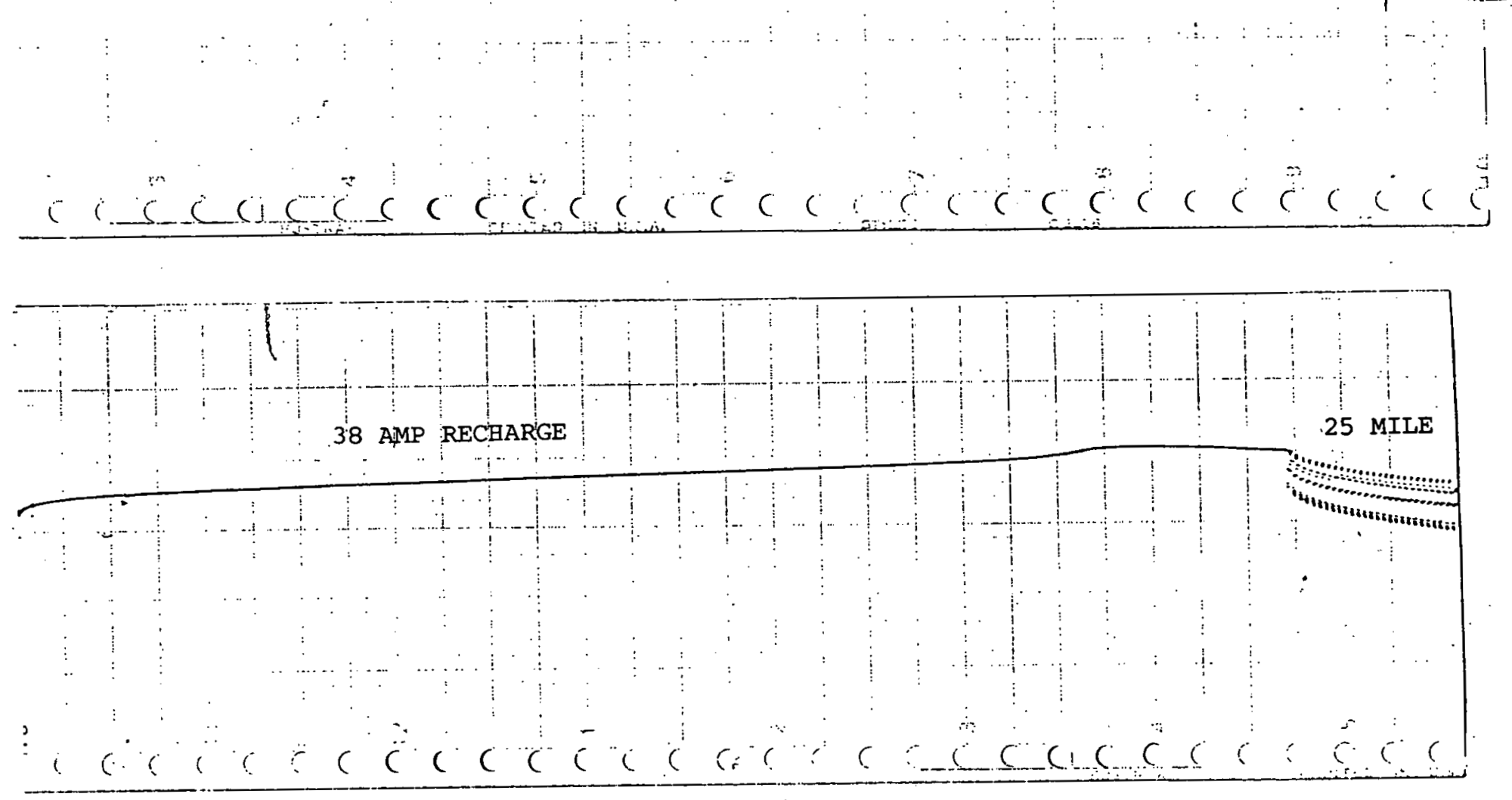

FIGURE V.15

SIMULATEJ EV USE TESTING OF CELI 162 


\section{ENERG RESEARCH CORPORATION}

the 230 Ah removed in the 100-mile discharge. The decay in the cell range, in miles, with cumulative equivalent mileage is shown in Figure V.16.

These results indicate that an early design capable of only 30 cycles at $77 \%$ DOD had an ecsuivalent range of 100 miles after 4500 cumulative miles use and 60 miles after 12700 miles use. This result is promising in terms of the suggested potential of more advanced desigus un this test.

\subsection{CONCLUSIONS}

The work done during the past year under this task of the project has centered on improving the performance of full-size EV cells. By replacing small cells with full-size single electrode cells, the design optimization effort was concentrated more on the problems of large cell performance. The development work has led to significant improvements in zinc electrode and separator system design.

The tests conducted on various zinc electrodes have led to the selection of electrode designs which are superior to the $\mathrm{Bi}_{2} \mathrm{O}_{3}$ additive in electrochemical performance and physical stability in large cells. The cdo/Pbo binary additive is currently considered the best design tested up to this point.

The separator system design studies have led to the selection of cellulose acetate coated celgard $\mathrm{K}-306$ as the most promising separator tested to date. In addition to being more stable than PVA, the microporous K-306 also allows greater mass transport than PVA, preventing the establishment of concentration gradients which impede cell performance. The lests have also demonstrated the need for an improved negative electrode ab- 
VARIABLE DEPTH LIFE TEST. 


\section{ENERGY RESEARCH CORPORATION}

sorber wrap, and asbestos has given the best results to date.

Earlier in the year, cells with PVA separator and $\mathrm{Bi}_{2} \mathrm{O}_{3}$ negative additive were capable of delivering 55 cycle on a $77 \%$ DOD cycle test without reconditioning during the test. In the full-size single electrode test, the design ran 70 cycles. Cells with $\mathrm{k}-306$ separator, asbestos negative plate absorber and $\mathrm{CdO} / \mathrm{PbO}$ inc additive have delivered more than 240 cycles in the single electrode test and 130 cycles in 250 Ah cells. These cycle results were achieved without reconditioning and with periodic electrolyte addition the only periodic maintenance procedure.

\section{0 FUTURE WORK}

The system engineering effort during the next year will focus on determining the reproducibility of the cycle test performance in cells with optimized components. In addition, testing will determine characteristics of the new design, such as open circuit capacity loss, thermal response, and performance on the vehicle use simulation test.

The vehicle simulation test will become an integral part of EV cell design evaluation. Testing will be conducted to determine life on the constant current test and performance on the vehicle simulation test.

Of the various charge procedures examined, constant current chargining produced the best results. The charge technique currently preferred is constant current charging controlled by a metal-gas coulometer. Future work will include running the coulometer with 250 Ah cells on the vehicle simulation regime to provide data on the long-term accuracy of the pilot cell. 


\section{ENERGY RESEARCH CORPORATION}

Evaluation of new component technology will continue in single electrode and 250 Ah cell tests. Commercial and in-house separator materials will be evaluated as they are developed. Zinc electrode development will continue, with emphasis on stable electrode constructions. The long cell design has shown promising cycle performance as well as improved thermal behavior and will be studied further. 
Internal:

J. J. Barghusen

D. Barney

M. H. Bhattacharyya

C. Bean

E. S. Beckjord

M. Bernard

E. C. Berrill

R. Biwer

A. Brown

L. Burr is

G. Chapman

A. A. Chilenskas

C. C. Christianson

G. Cook

D. Corp

$P$. Cunn ingham

F. Creamer

S. A. Davis

W. Deluca

R. C. Elliott

M. Farahat

P. R. Fields

F. Foster
D. Fredrickson

B. R. T. Frost

E. C. Gay

J. Geller

M. Genge

D. Graczyk

E. Hayes

L. Hill

F. Hornstra

C. C. Hsu

v. Kolha

J. Klinger

V. Kremesec

A. B. Krisciunas

M. Kronenberg

S. J. LaBelle

T. S. Lee

M. Liu

R. Loutfy

W. Massey

J. Meisenhelder

J. Miller .
W. Miller

P. A. Nelson

M. V. Nevitt

E. G. Pewitt

D. Poa

J. Rajan

J. J. Roberts

M. F. Roche

H. Sh imot ake

R. K. Steunenberg

C. Swoboda

Z. Tomczuk.

A. Tummilio

R. Varma

P. D. Vashishta

D. R. Vissers

D. S. Webster

F. Williams

F. Wyant

N. P. Yao (44)

ANL Contract File

ANL Libraries

TIS Files (6)

\section{External:}

DUE-TIC, for distribution per UC-94ca (318)

Manager, Chicago Operations and Regional office, DOE Chief, Office of Patent Counse1, DOE-CORO

V. Hummel, DOE-CORO

R. Gariboldi, DOE-CORO

Argonne Universities Association:

President

C. B. Alcock, U. of Toronto

W. L. Worrell, U. of Pennsylvania

W. Ahmad, KW Battery, Skokie, IL

R. Alkire, University of Illinois, Urbana

M. Allen, Mechanical Technology Inc., Latham, NY

E. T. Ames, TRW Systems, Redondo Beach, CA

$L$. Andrews, Electric Vehicle Council, Washington, $D C$

S. J. Angelovich, Mallory Battery Co., Tarrytown, NY

G. M. Arcand, 1daho State University, Pocatello

R. Aronson, Electric Field Propulsion Corp., Troy, MI

G. N. Ault, NASA Lew is Research Center

J. D. Baker, Stewart Warner Corp., Chicago

W. Bales, Jet Industries, Inc., Aust in

H. Balzan, Chattanooga, TN

K. F. Barber, DOE, Offiçe of Transportation Programs, Washington 
T. Barber, Jet Propulsion Laboratory, Pasadena

R. J. Bark ley, Compass Industries Inc., Hermosa Beach, CA

T. M. Bar low, Lawrence Livermore Laboratory

J. H. Hampton Barnett, Tennessee Valley Authority, Chattanooga

R. Barnstead, Aerospace Corporation, Washington DC

D. Barron, Delco-Remy Div., GMC, Anderson, IN

R. Bassett, Sandia Laboratory, Albuquerque

W. Bauer, Hittman Associates Inc., Columbia, MD

W. Bauer, KW Battery, Skokie, IL

E. Baumann, LILCO, Mineola, NY

W. C. Beasley, Union Carbide Corporation, New York, NY

H. Bell, Arizona Public Service Co., Phoenix

J. Bellack, Cleveland Electric Illuminat ing Co., Cleveland

L. Belove, Marathon Battery Corp., Waco, TX

W. R. Benn, Great Lakes Carbon Corporation, New York

D. Bennion, Brigham Young University, Provo, UT

C. Berger, Electrochemical \& Water Desal. Technology, Santa Ana, CA

D. Bergmann, GM Transportation Systems Center, Warren, MI

L. Berkowitz, Esso Research Co., Linden, NJ

C. Berlsterling, C. Franklin Research Institute, Philadelphia

J. Birk, Electric Power Research Institute, Palo Alto

W. S. Bishop, Air Force Aero Propulsion Lab, Wright-Patterson AFB

D. P. Boden, C\&D Batteries, Plymouth Meet ing, PA

D. Borrello, Die Mesh Corporation, Pelham, NY

A. Borucka, Borucka Research Co., Livingston, NJ

P. Bowen, C\&D Batteries, Plymouth Meet ing, PA

D. Bowman, United States Postal Service, Washington

J. C. Boylan, Electric Dynamics Corp., Plainwel1, MI

B. J. Bragg, Bell Laboratories, Murray $\mathrm{Hill}$, NJ

J. Brennand, General Research Corp., Santa Barbara

A. F. Brewer, Malibu, CA

D. C. Briggs, Philco-Ford Corp., Palo Alto

P. Bro, P. R. Mallory \& Co., Inc., Burlington, MA

J. Broadhead, Bell Laboratories, Murray $\mathrm{Hill}$, NJ

E. P. Broglio, Eagle-Picher Industries, Joplin, MO

A. D. Brown, EVE Electric Motor Car, Inc., East Lansing, MI

P. J. Brown, DOE, Office of Transportation Programs, Washington

R. A. Brown, Eagle-Picher Industr ies, Jop 1 in, M0

B. S. Brummer, EIC Corporation, Newton, MA

J. Bucci, C\&D Batteries, Plymouth Meeting, PA

R. Buchholz, Honeywell Corp., Minneapol is

A. J. Burgess, Lucas Industries, Inc., Troy, MI

H. Burghart, Cleveland State University, Cleveland

D. Burns, Onan Corporation, Minneapol iss

B. W. Burrows, Gould Inc., Rolling Meadows, IL

M. Burtgon, Delco-Remy Div. of GMC, Anderson, IN

J. D. Busi, USA Foreign Science \& Tech. Center, Char lottesville, VA

E. Buzzelli, West inghouse Electr ic Corp.; Pittsburgh

W. P. Cadogan, Emhart Corp., Hartford, CT

E. Cairns, Lawrence Berkeley Lab.

E. Campbe 11, Electric Vehicle Consultants, Inc., New York, NY

P. Campbe11, University of Southern Cal ifornia, Los Angeles

1. Campbel1, DOT/UMTA, Wash ington, DC

1. T. Carpenter, Kimberly Clark Corp., Neenah, WI 
T. V. Carvey, Hughes Aircraft Corp., Culver City, CA

A. Charkey, Energy Research Corp., Danbury, CT

L. D. Christian, General Electric, Gainesville

R. C. Chudacek, McGraw Edison Co., Bloomf ield, NH

R. Clark, Sandia Labs., Albuquerque

J. E. Clifford, Battelle Memorial Inst itute, Columbus

J. A. Consiglio, Solva-Tek Associates, Topsfield, MA

A. R. Cook, ILZRO Inc., New York

K. E. Cooper, Trojan Battery Co., Santa Fe Springs, CA

G. Coraor, E. I. DePont de Nemours \& Co., Inc., Wilmington, DE

R. E. Corbett, Lockheed Missiles \& Space Co., Sunnyvale

D. Crane, United States Postal Service, Washington

R. A. Crawford, PPG Industries, Barberton, $\mathrm{OH}$

C. Dacres, White Oak, Silver Spring, MD

R. H. Dare, Battronic Truck Corp., Boyertown, PA

D. Davis, Lawrence Liverimore Laboratory

R. J. Dawson, Exide Management and Technology lo., Mádison, WI

G. A. DeBari, INCO, Sterling Forest, Suffern, NY

J. Devitt, Denver, CO

A. N. Dey, P. R. Mallory \& Co. Inc., Burlington, MA

W. J. Dippold, DOE, Office of Transportation Programs, Washington, DC

T. P. Dirske, Calvin College, Grand Rapids, MI

D. Divirgillo, Lockheed Missiles and Space Co: Inc., Sunnyvale

D. Douglas, Electric Power Research Institute, Palo Alto

D. Dow, Detroit, MI

D. Dunoye, Reston, VA

T. Dwyer, Corning Glass Works, Corning, NY

E. F. Echolds, A iResearch Manufacturing Co., Torrance, CA

M. Eisenberg, Electrochimica Corp., Mountain View, CA

D. B. Eisenhaure, Charles Stark Draper Lab., Inc., Cambridge, MA

$T$. Eissenberg, Oak Ridge National Lab.

M. W. Ellison, Hughes Aircraft Corp., El Segundo

D. Elson, Black and Decker Inc., Towson, MD

C. Engl ish, University of New Mexico, A Ibuquerque

R. English, General Battery Co., Reading, PA

B. Enserik, Dynamic Science, Phoenix

R. Enters, McGraw Edison Co., Bloomf ield, NJ

H. Espig, Gould Inc., Rolling Meadows, IL

E. C. Essig, Long Is land Light ing Co., Mineola, NY

A. Ewing, DOE, Office of Transportation Program, Washingtonn

G. Farbman, West inghouse Electric Corp., Pittsburgh

D. W. Fedor, Bcll Laboratories, Murray Hill, NJ

R. Fedora, Gould Inc., Rolling Meadows, IL

W. Feduska, West inghouse Electr ic Corp., Pittsburgh

W. H. Fengler, Meteor Research Limited, Roseville, MI

F. Feres, KW Battery Co., Skokie, IL

R. Ferraro, Electric Power Research Inst itute

D. T. Ferrell, Exide Management and Technology Co., Yardley, PA

E. Fiss, Duke Power Co., Char lotte, NC

A. Fleischer, Orange, NJ

C. W. Fleischmann, C\&D Batter ies, Plymouth Meeting, PA

R. F. Fogle, North American Rockwell, Anahe im

R. T. Foley, Amer ican University, Washington, DC

F. Fontana, Consolidated Edison Co., Astoria, NY 
L. R. Foote, Vehicle Systems Department, Ford Motor Co., Dearborn, MI

J. S. Fordyce, NASA Lewis Research Center

H. A. Fuggiti, Exide Management and Technology Co., Yardley, PA

T. Fujita, Pasadena, CA

B. Ganji, KW Battery Co., Skokie, IL

G. Gelb, Advanced Ground Systems, Long Beach, CA

J. H. B. George, George Consult ing International Inc., Concord, MA

S. Geppert, Eaton Corporation, Southfield, MI

L. J. Gerlach, United States Postal Service, Rockville, MD

J. A. Gilchrist, Chloride America, Tampa

W. Gillespie, Structural Plastics Inc., Tulsa

J. R. Gilmore, Ford Motor Co., Dearborn, MI

C. Glassman, Transportation Research Center, East Liberty, $\mathrm{OH}$

H. Glixon, Chevy Chase, MD

M. Globerman, General Services Administration, Washington

W. Goldman, Electr ic Vehicle Engineering, Lexington, MA

G. Goodman, Globe Battery Division, Milwaukee

R. E. Goodson, Purdue University

J. Gould, Unique Mobility Inc., Englewood, CO

L. B. Gratt, IWG Corp., San Diego

G. Greenberg, Electric Vehicle Battery Technology, Stamford, CT

H. Grepke, TurElec Inc., Bradenton, FL.

D. Griter, Solar Centra, Mechanicsburg, $\mathrm{OH}$

E. E. Grough, Lucas Industries Inc., Troy, MI

R. Guess, General Electric Research Lab., Schenectady

R. G. Gunther, General Motors Research Labs., Warren, MI

M. Hadden, Bill ing Energy Corp., Provo, UT

$G$. Hagey, DOE, Divis ion of Technology Overview, Washington

H. Hamilton, University of Pittsburgh

W. Hamilton, General Research Corp., Santa Barbara

B. Hamlen, Exxon Enterprises Inc., Florham Park, NJ

D. Han ify, Fiat, Chicago.

K. L. Hanson, General Electric Co., Philadelphia

W. Harhay, Electric Vehicle Associates, Clevel and

J. H. Harrison, Naval Ship R\&D Center, Annapolis, MD

G. Hartman, Exide Management and Technology Co., Yardley, PA

J. Hartman, General Motors Research Labs., Warren, MI

C. Hayden, General Telephone and Electronics, Stamford, CT

E. A. Heintz, Airso Speer Carbon Graphite, Niagara Falls, NY

E. V. Hellman, Gould Inc., Langhorne, PA

R. Heppenstall, Penn Jersey Suburu Inc., Pennsauken, NJ

A. Himy, Naval Sea Systems Command, Washington

V. Hlavin, NASA Lew is Research Center

G. Hobbib, Exide Management and Technology Co., Cleveland

M. Hodgman, General Electric, Gainesville

R. Hoenburg, Mechanical Technology Inc., Latham, NY

R. Hudson, Eagle-Picher Industries, Joplin, Mo

J. R. Huff, US Army Mobility Equipment R\&D Command, Fort Belvoir, VA

H. L. Hughes, OK lahoma State University, Stillwater

W. Hull, USPS Research and Development Laboratory, Rockville, MD

B. Iseard, Freeport, Bahamas

H. R. Ivey, Wood-Ivey Systems Corp., Winter Park, FL

J. Jacus, Moore Haven, FL

M. A. Jansen, Allegheny Power Service Corporation, Greensburg, PA 
G. H. Jantz, Rensselaer Polytechnic Institute

A. W. Johnson, General Electric Co., Philadelphia

L. Jok 1, MERADCOM, Fort Belvoir, VA

K. R. Jones, Thiensville, WI

W. J. Jones, West inghouse Electric Corp., Pittsburgh

R. E. Jordan, Omega Motors Corp., Garden Grove, CA

D. Kane, Nat ional Motors Corp., Lancaster, PA

E. Kanter, Gulton Battery Corp., Metuchen, NJ

N. Kaplan, Harry Diamond Labor atories, Washington

V. Kapur, Arco Solar Inc., Chatsworth, CA

R. Kaylor, Kaylor Energy Products, Menlo Park

J. Keith, Kaman Sciences, Colorado Springs, CO

J. J. Kelley, Exide Corporation, Yardley, PA

H. C. Kelly, OTA, U.S. Congress, Washington

J. G. Kennard, NASA Lewis Research Center

R. L. Kerr, Aero Propulsion Lab., Wright Patterson AFB

J. A. Kerrella, Delco-Remy Division/GMC, Anderson, IN

R. A. Keyes, Robert A. Keyes Associates, Martinsville, IN

R. A. K'ingery, Oconomowoc, WI

R. S. Kirk, DOE, Office of Transportation Programs, Washington

M. Klein, Energy Research Corporation, Danbury, CT

G. B. Kliman, General Electric Co., Schenectady

G. B. Kl inean, General Electric Co., Schenectady.

R. C. Knecht li, Malibu, CA

R. A. Knight, AMF Inc., Stamford, CT

0. R. Kozak, American Battery Corp., Long Beach, NY

J. G. Krisilas, Aerospace Corporation, El Segundo, CA

$P$. E. Krouse, Exide Management \& Technology Co., Yardley, PA

R. R. Kubalek, St. Joe Lead Co., Clayton, MD

L. Kulin, Whirlpool Corp. Benton Harbor, MI

C. M. Langkau, Union Carbide Co., Cleveland

H. I auve, Electric Auto Corporation, Troy, MI

E. Lawlor, Membrana Incorporated, Chicago, IL

J. Lee, RAI Research Corp., Hauppauge, NY

I. J. Levine, Consol idated Ed ison, New York

K. Levine, St. Joe Minerals Corp., Pittsburgh

H. Lim, Hughes Research Lab., Mal ibu, CA

D. Linden, Little Silver, $\mathrm{NJ}$

E. L. Littauer, Lockheed Pàio Alto Research Labüratury

A. Long, Zeonics Corp., Fairfax, VA

E. Long, St. Joe Minerals Corp., Monaca, PA

P. Lu, West inghouse Electr ic Corporation, Pittsburgh, PA

J. T. Lundquist, W. R. Grace \& Co., Columbia, MD

T. Lynch, Fiber Malerials, Inc., Biddeford, ME

E. N. Mabuce, Union Electric Co., St. Lou is

J. MacDougall, AT\&T, Bask ing Ridge, NJ

D. E. Mains, Naval Weapons Support Center, Crane, IN

J. Mader, Electric Power Research Institute, Palo Alto, CA

J. Maisel, Clevel and State University, Cleveland

J. S. Makulowich, Electric Vehicle Council, Washington

V. Manson, National Aeronautics and Space Adm., Washington

L. Mapa, KW Battery, Skokie, IL

L. S. Marcoux, Hughes Aircraft Company, Los Angeles

T. W. Martin, United States Postal Service, San Bruno, CA 
J. Masson, Mart in Mar ietta Corp., Denver, CO

C. E. May, NASA Lewis Research Center

E. Meeks, Der 1 Manufacturing Co., Compton, CA

J. D. Meiggs, Kaman Sciences Corp., Colorado Springs

P. Mighdoll, Booz-Allen \& Hamilton, Cleveland

R. P. Mikkelson, General Dynamics, San Diego

D. G. Miley, U.S. Naval Ammunition Depot, Crane, IN

H. Miller, Department of Transportation, Cambridge, MA

D. K. Miner, Copper Development Associates, Birmingham, MD

L. G. Mor in, Tarrytown, NY

F. Morse, Silver Spring, MD

A. Moss, Leesona Moos Laboratories, Warwick, RI

R. Mueller, University of California, Berkeley

J. H. Muir, Dimension V Inc., Indialant ic, FL

J. P. Mullin, National Aeronautics \& Space Administration, Washington

G. Murphy, Northwestern University

N. T. Musial, Nasa Lewis Research Center

B. McCormick, Los Alamos Scient if ic Lab.

L. R. McCoy, Energy Systems Group, Canoga Park

A. H. McCutcheon, Texas State University, Waco, TX

R. Mckee, McKee Engineering, Palat ine, IL

F. MCLarnon, Lawrence Berkeley Lab.

J. N. MCNamara, Northrup Corporation, Hawthorne, CA

P. MCRay, ILC Technológy, Sunnyvale

W. J. Nagle, NASA Lewis Research Center

L. Nalley, Creative Research Co., Roebuck, SC

J. Newman, Univ. of California, Berkeley

J. S. Newton, Newton Engineering Co., Glen Ellyn, IL

A. 0. Nilsson, NIFE Incorporated, Lincoln, RI

J. Norberg, Exide Management \& Technology Co., Philadelphia

A. C. Occhipinti, Kenner, LA

L. G. O'Conne 11, Lawrence Livermore Lab.

G. Odom, Georgia Power Company, Atlanta, GA

R. Oglesby; GM Transportation Systems Ctr., Warren, MI

L. Omohundro, Kingery Research \& Development, Wake Forest, NC

E. I. Onstott, LoS ATamos Scient if ic Lab

R. Osteryoung, State University of New York at Buffalo

B. N. Otzinger, North Americari Avialion, Downey, CA

J. P. Overman, Hammond Lead Products Inc., Hammond, IN

J. E. Oxley, Gould Inc., Rolling Meadows, IL

E. Papandreas, REI, Lake Worth, FL

J. S. Parkinson, Johns-Manville R\&D Center, Manville, NJ

J. M. Parry, Arthur D. Little Inc., Cambridge, MA

E. Patagalia, General Services Administration, Washington

S. Pauling, Naperville, IL

J. E. Pavolisky, NASA/Lyndon B. Johnson Space Ctr., Houston

C. Pax, DOE, Office of Transportation Programs, Washington

E. Pearlman, Exide Management and Technology Co., Yardley, PA

J. P. Pemsler, Cast le Technology Corp., Lexington, MA

G. F. Pezdirtz, DOE, Office of Advanced Conservation Technology, Washington

A. Pivec, Public Service Electric and Gas, Newark, NJ

A. G. Plunckett, General Electr ic R\&D Center, Schenectady

R. A. Powers, Union Carbide Corp., Clevcland

V. J. Puglisi, Yardney Electric Corp., Pawcatuck, CT 
E. Ramirez, Amectran, Dallas

A. D. Raynard, AiResearch Manufacturing Co., Torrance, CA

E. C. Read, Exxon Enterprises, Linden, $\mathrm{NJ}$

H. L. Recht, Atomics International Division, Canoga Park

C. Ridgway, Walt Disney World Co., Lake Buena Vista, FL

W. Rippel, Jet Propulsion Laboratory, Pasadena

E. Rizkalla, DOE, Office of Controller, Washington

R. A. Rizzo, Globe Battery Division, Milwaukee

R. Robert, The MITRE Corporation, McLean, VA

F. T. Rooney, Bureau of Automotive Maintenance, Norfolk, VA

L. Rosenblum, NASA Lewis Research Center

N. Rosenburg, Department of Transportation, Cambridge, MA

R. Rosey, West inghouse, P ittsburgh

1. Rossmon, Cornell University

G. Rowl and, General Electric, Schenectady

il. Ruhenzer, NASA Ames Research Center, Moffett Field

P. H. Rubic, Electric Passenger Cars, Inc., San Diego

H. E. Ruskie, Naval Intelligence Support Center, Washington

A. J. Salkind, Rutger Medtcal Schuol, P iscalaway, NJ

R. T. Schneider, RTS Laboratories, Gainesville, FL

L. W. Schopen, NASA Lew is Research Center

H. J. Schwartz, NASA Lewis Research Center

W. R. Scott, TRW Systems Inc., Redondo Beach

H. Seigel, South Coast Technology Inc., Santa Barbara, CA

H. Seiger, Harvey Seiger Associates, Waterford, CT

J. Sel iber, Fluid Drive Engineer ing Co., Wilmette, IL

E. Seo, Gates Energy Products, Denver, Co

L. Shahnasarian, Elcar Corp., Elkhart, IN

R, C. Shair, CENTREC Corporation, Fort Lauderdale

H. Shalit, ARCO Chemical Corp., Glendolden, PA

D. W. Sheibley, NASA Lewis Research Center

G. L. Silverman, Ford Motor Co., Dearborn, MI

E. Sma11, Amectran Corporation, Washington

G. A. Smith, [nglehard Industrics, Isel in, NJ

S. Smith, St. Joe Minerals Corp., Monaca, PA

V. Smith, Delco-Remy Div. GMC, Anderson, IN

J. Smits. Nevada Operations Office, Las Vegas

I. J. Soloman, IIT Research Inst itute, Chicago

W. C. Spindler, Electric Power Research Institute, Palo Alto

J. S. Stanley, U.S. Army Foreign Sci. \& Tech. Center, Charlottesville, VA

$\bar{E}$. J. Steeve, Commonwealth taison Co., Chtcagu

I. Stein, Jet Propulsion Laboratory, Pasadena

T. A. Stonehanı, Marathon Battery Company, Wacu, TX

R. Strauss, Communications Satellite Corp., Clarksburg, MD

W. E. Strawbridge, Caterpiller Tractor Co., Peoria, IL

R. L. Strombotne, DOE, Department of Transportation, Washington, DC

S. Sudar, Rockwell International, Canoga Park

P. C. Symons, Birmingham, MI

F. Tepper, Catalyst Research Corp., Balt imore

R. Thacker, General Motors Research Labs, Warren, MI

C. E. Thomas, Chrysler Corpor at ion, New Orleans, LA

F. Thomas, Grumman Aerospace Corp., Bethpage, NY

M. Thorpe, Towson, MD

G. M. Thur, DOE, Office of Transportation Programs, Washington 
W. H. Tiedemann, Globe Battery Division, Milwaukee

C. W. Tobias, University of California, Berkeley

A. Topouzian, Ford Motor Co., Dearborn, MI

W. Toth, Society of Automotive Engineers, Inc., Warrendale, PA

H. Toulmin, Bloomf ield, MI

I. Trachtenberg, Texas Instruments, Dallas

J. C. Trocciola, United Technologies Corp., South Windsor, CT

G. W. Tuffnell, The International $\mathrm{Nickel}$ Co., Troy, MI

D. Turford, Western Mining Corp., Pittsburgh

G. H. Turney, Western Research Industries, Las Vegas, NV

E. A. Ulrich, Creative Automotive Research, Whittier, CA

R. L. Ulrich, General Services Administration, Washington

T. Ulrich, MCGraw-Edison Co., Bloomfield, NJ

G. Underhill, A. D. Litt le, Cambridge, MA

H. B. Urbach, Naval Ship R\&D Center, Annapol is, MD

H. Vaidyanathan, Energy Research Corp., Danbury, CT

C. J. Venuto, C\&D Batteries, Plymouth Meet ing, PA

S. W. Vreeland, General Dynamics, Convair Division, San Diego

A. Wadde 11, EBCO Battery Co., Columbus, GA

E. H. Wakefield, Linear Alpha Inc., Evanston, IL

R. Walker, University of Florida, Gainesville

C. H. Waterman, C. H. Waterman Industries, Althol, MA

G. Way, Troy, MI

W. Webster, DOE, Off ice of Advanced Conservation Technology, Washington

R. D. Wehrle, Sandia Labs, Albuquerque, NM

S. A. Weiner, Ford Motor Co., Detroit, MI

C. Weinlein, Globe Battery Division, Milwaukee

M. We inreb, Con Edison, New York

E. Y. Weissman, GASF Wyandotte Corp., Wyandotte, MI

I. Wender, Bureau of Mines, Pittsburgh, PA

H. B. West, McGraw-Edison Company, B loomf ield, NJ

J. H. Whitmore, B inghamton, NY

M. E. Wilke, Burgess Battery Company, Freeport, IL

R. Wilks, Lavelle Aircraft Co., Newton, PA

C. F. Williams, Teledyne Isotopes, Timonium, MD

H. R. Will iams, Detroit Edison Co., Detroit

J. M. Williams, E. I. duPont. de Nemours \& Cn., Wilmington, DE

E. Willhnganz, C\&D Batteries, Plymouth Meet ing, PA

N. L. Willmann, Delco Remy Div. of GMC, Anderson, IN

J. F. Wing, Booz-Allen \& Hamilton Inc., Bethesda, MD

G. A. Wooldrige, Boeing Aerospace Co., Seattle

V. Wouk, Petro-Electric Motor Ltd., New York

R. A. Wynveen, Life Systems Inc., Cleveland

L. Yanni, Booz-Allen and Hamilton, Bethesda, MD

L. S. Yao, University of 111 ino is, Urbana

H. Yoder, Battronic Truck Corp., Boyertown, PA

M. Yontar, Jersey City, NJ

R. Zalosh, Factory Mutual Research, Norwood, MÁ

J. E. Zanks, NASA Langley Research Center, Hampton, VA

M. Zlotnick, Divison of Conservation Research and Technology, Washington, DC 